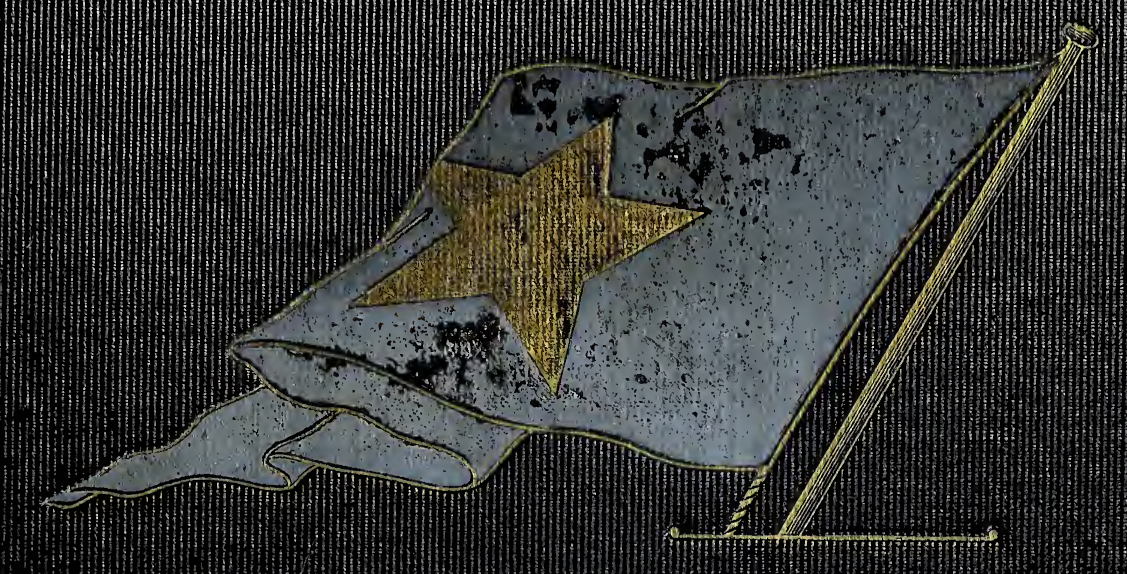

\title{
THE CURSE OF
}
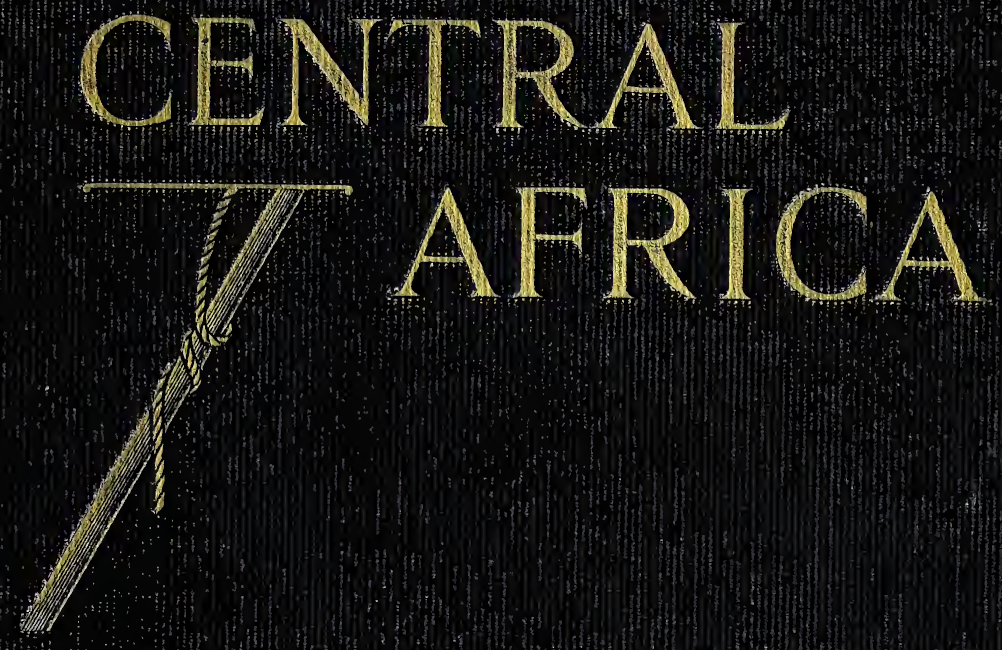

\section{CAPTAIN GUY BURROWS}



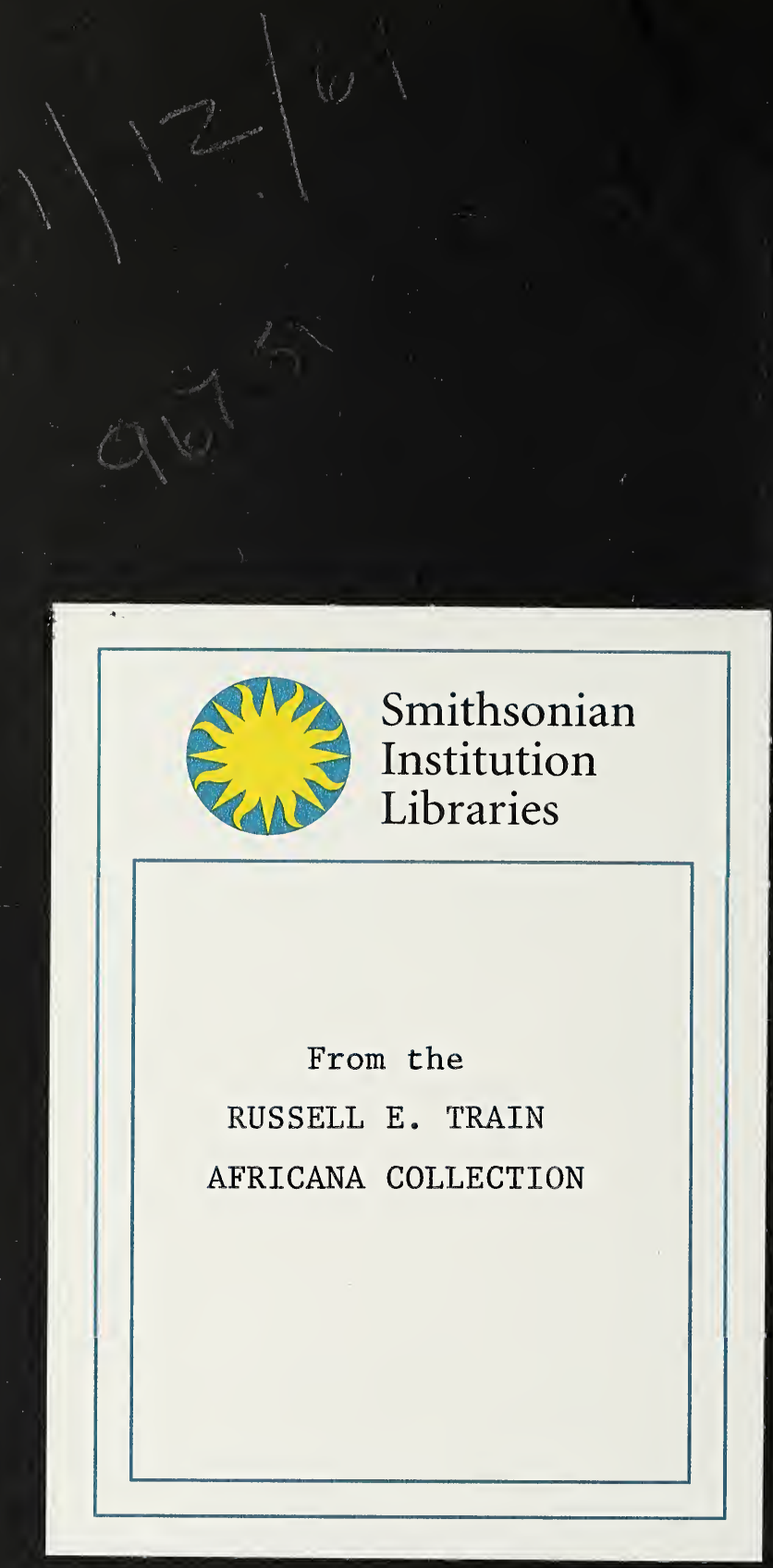


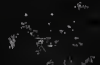

n

(x) 



$$
\begin{aligned}
& 6^{90} \\
& +16^{5}
\end{aligned}
$$

THE CURSE OF CENTRAL AFRICA 


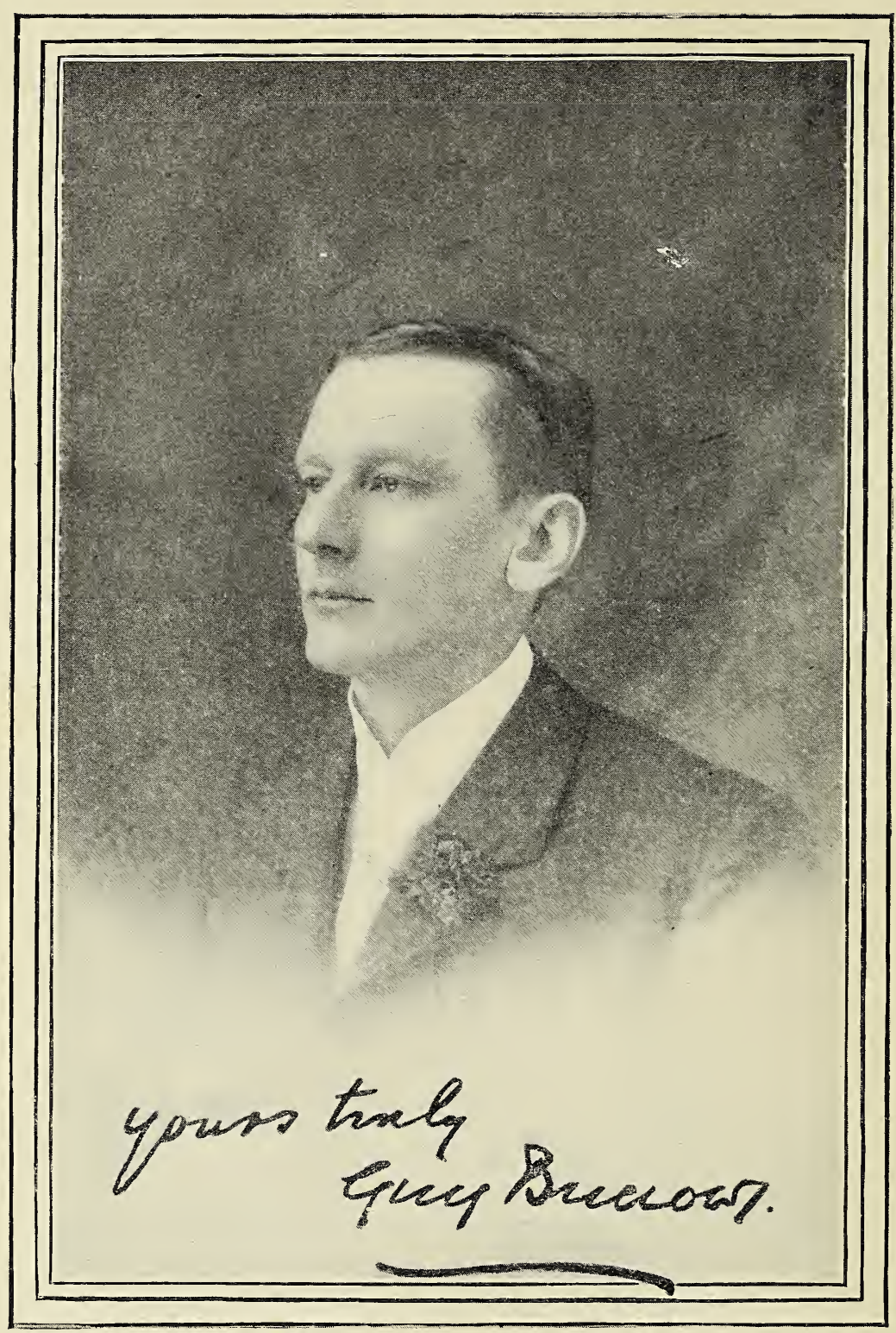

LATE DISTRICT COMMISSIONER OF THE ARUWIMI DISTRICT OF THE CONGO FREE STATE. 


\title{
THE
}

\section{Curse of Central Africa}

BY

\section{CAPTAIN GUY BURROWS,}

AUTHOR OF " THE LAND OF THE PIGMIES,"

LATE DISTRICT COMMISSIONER OF THE ARUWIMI DISTRICT OF THE CONGO 'FREE STATE; CHEVALIER DE

L'ORDRE DU LION, \&C.

WITH WHICH IS INCORPORATED

A

Campaign Amongst Cannibals

\author{
EDGAR CANISIUS.
}

Formerly of the Congo State Service and Agent of the Société Anversoise du Commerce au Congo.

With Coloured Map and numerous Illustrations from Unigue and Valuable Photographs taken by the Author and others.;

\section{IOndoon :}

R. A. EVERETT \& CO., LTD.,

42, ESSEX STREET, STRAND, W.C.

1903.

(All Rights Reserved.) 
Third Impression.

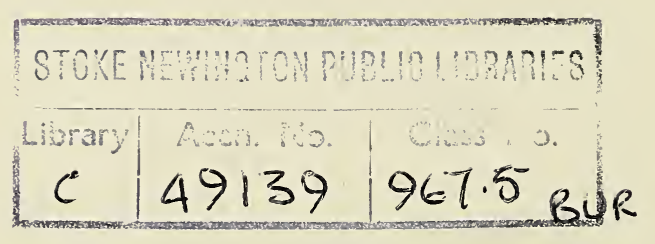


DT

646

B97

$1903 b$

SCNHNON

\section{LEOPOLD II.}

KING OF THE BELGIANS AND SOVEREIGN OF THE CONGO FREE STATE.

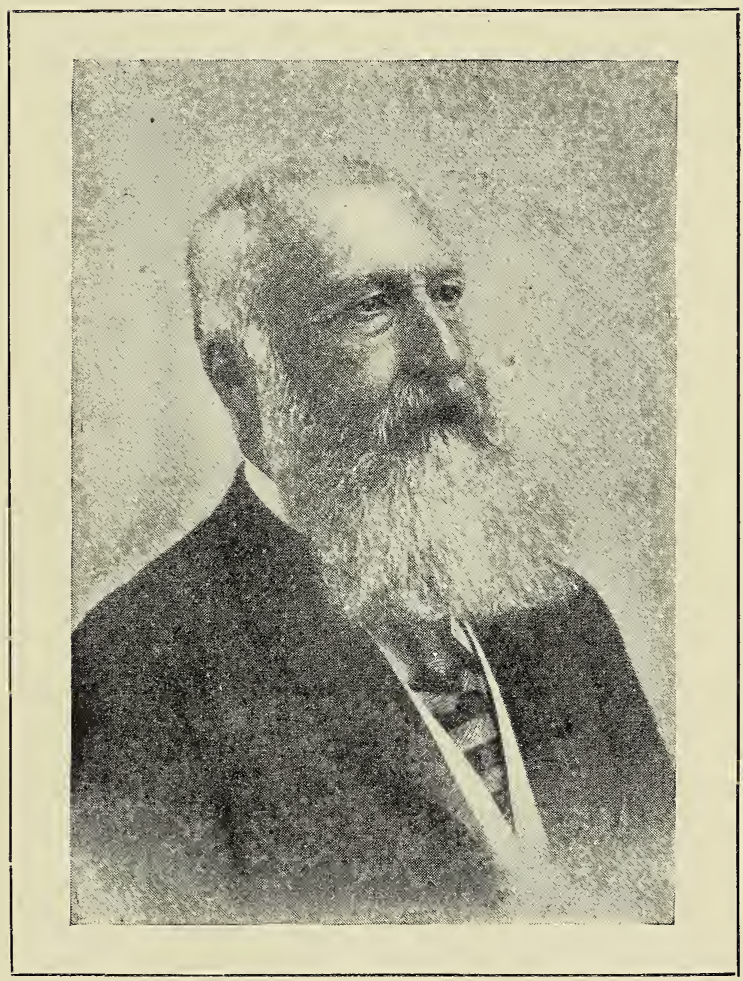





\section{INTRODUCTION.}

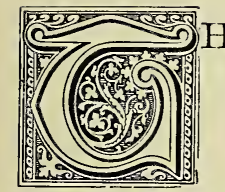

HIS volume is issued from the press under circumstances so remarkable that they may, without undue emphasis, be described as unprecedented in the modern annals of British publishing. The incidents call for widespread consideration, the urgent attention of all concerned in the production of the work, and pre-eminently of him to whom has been deputed the duty of introducing it to the public. Under ordinary conditions the preparation of a preface to such a volume would be a relatively facile task. It is not so at the present juncture, for, while the circumstances referred to cannot be ignored, it is necessary to allude to them with more than the ordinary reserve imposed in such cases by usage and convention.

Criticisms of the methods of administration favoured by the Independent State of the Congo, and of the latter's contemptuous disregard of the obligations to which it assented as conditions of its creation and recognition by the Powers, have, during the past decade or more, been equally numerous and frequent. Thanks, however, to international jealousies; to hopes of early reformation, doomed ever to be disappointed; to a lingering faith in the good intentions of the Sovereign; and to the specious explanations and apologies offered by the State and its more or less accredited representatives in various lands, no serious endeavour has ever been made to investigate the actual conditions or provide for their eventual betterment. 
Except on rare occasions, to which I shall hereafter very briefly refer, King Leopold, his counsellors, and their friends abroad have deemed it necessary, when criticised, to do little more than pose as much misunderstood and maligned philanthropists. The "mission" of the State, according to their view, is so high-minded and majestic as to palliate, if not justify, every evil accidental to it, which may from time to time be disclosed. With a loftiness of tone and unctuous insistence upon the purity and unselfishness of their intentions, which in a less serious matter would be appropriate subject for ridicule, they have claimed, throughout the world, not only an exclusive prerogative of superiority to adverse comment, but even a prescriptive right to disregard the ordinary obligations of humanity and organised society. Having closed nearly the whole State to all save officials and dependents, they have deemed themselves in a position to ignore or laugh to scorn all allegations of wrong-doing which may periodically stir the conscience of Belgium or of the other nations primarily responsible.

Of necessity, the greater number of charges thus made must emanate from persons who have held positions under the Congo Administration or lesser commercial monopolies. Belgians returning to their native land cannot, for very obvious reasons, publish their actual sentiments, and the duty of proclaiming the truth has consequently in the main devolved upon the few capable foreigners who have been sufficiently fortunate to retire from the Independent State with the blessings of life and health. In this connection it is well to remember that early in 1898 a circular was received at every post throughout the State, issued from Boma by the then Governor-General, M. Wahis, which notified all employés that-as it had come to the knowledge of the Administration that information in regard to the affairs of the Congo had become public in the European press, founded, possibly, 
upon private correspondence of some of the agents of the Stategreater discretion must in future be observed in all letters addressed to relatives and friends at home, and that any agent disregarding this caution would incur the serious displeasure of the Government. To this notification, of course, no serious objection can be taken. The Congo Government was well within its rights in such disciplinary provision; but it is overstepping every reasonable bound when it asks the world to believe that every employé who may dare, after leaving its service, to comment upon circumstances within his knowledge, is either a natural object for suspicion or has interested motives for distorting or exaggerating facts.

Having indoctrinated the world with this vicious idea, every available and dishonourable advantage of the fact has been taken by the Administration of the Congo State and its allies in England and elsewhere. Of the normal attitude of the Press, with few distinguished exceptions, I forbear to write-it is a subject of painful reflection to one who, during a quarter of a century, has sought to preserve unsullied the best traditions of his profession. Had there been less unwillingness on the part of English journalism to acquaint itself with the evils of the systems described in the present volume, less willingness to accept the fulsome declarations of those responsible for these enormities, we should not now have to face a situation discreditable to our much-vaunted civilization and boding ill for the preservation of European peace. The nation would have balanced more fairly, in the light of obvious motives, the insidious and reiterated affirmations that matters in the Congo State could not be indifferent-indeed, other than preeminently satisfactory. For this verry happy issue of diplomacy and altruism two reasons have always been assigned-the first, that King Leopold and his coadjutors, by their own showing, were personages above censure or suspicion; the second, that the 
majority of individuals qualified to speak from close and personal observation must necessarily be prejudiced, discharged, or discredited employés. To the bona fides and accuracy of the latter statement, as applied to the authors of the present volume, it is desirable, and, indeed, essential that I should devote considerable measure of attention.

It was on the recommendation of Sir, then Mr. Henry M. Stanley, that the Government of the Congo State decided to avail itself of the services of Captain Guy Burrows, and that the latter, in order to accept the invitation, resigned his commission in the 7th Fusiliers. The engagement, as is usual with Congolese appointments, was for three years. At the expiration of this period Captain Burrows returned to Europe, but was subsequently re-engaged for a further and equivalent term. Thus, in all, he spent six years in the Congo State, first as Commandant of the Zones Makua and Rubi Uelle and afterwards as District Commissioner of the Aruwimi, with, in the latter instance, headquarters at Basoko. During this period, so far as I am informed, he fulfilled the various and oft-times, I am assured, very repugnant duties imposed upon him by his official positions to the entire satisfaction of the authorities - a circumstance attested by the fact that, when his second engagement terminated by effluxion of time, he held the rank of Chevalier de l'Ordre du Lion, the star for meritorious service, and other cheap decorations associated with mid-African sovereignty. More important, however, in this connection is a correspondence (between November, 1901, and January of the following year) between Captain Burrows and M. Charles Liebrechts, Secretary-General of the Department of the Interior of the Congo Free State. This is interesting, not only as evidence of the estimation in which, at this period, Captain Burrows was apparently held by the State authorities, but also because, by a strange turn of events, it is now being 
used by the latter to prove exactly"the reverse. In this connection it may, perhaps, be of interest to note that the following letters are textually identical with translations made by command of M. Liebrechts himself :-

\section{London,}

November 15th, 1901.

Dear Monsieur Liebrechts,

I should be very grateful if you would have the kindness to tell me if the State wishes to employ me again. If so, will you let me know the conditions? M. Canisius is here; he says that he is engaged in writing a book on the Congo.

Yours truly,

G. Burrows.

\section{Congo Free State,}

Department of the Interior, Brussels, November 23rd, 1901.

Dear Monsieur Burrows,

I have duly received your letter of the 15th November, and hasten to thank you for the communication you have been good enough to make me. I heard that M. Canisius was spreading certain calumnies about the State.

Yours truly,

Liebrechts.

\section{London,}

December 16th, 1901.

My Dear Monsieur Liebrechts,

I presume that your letter is a refusal on the part of the Free State to re-engage me for a third term of service. I beg you to enlighten me on this point; then I shall know whether I am free or not to do what I wish.

Yours truly,

G. Burrows. 


\section{Congo Free State,}

Department of the Interior,

Brussels, December 21st, 1901.

Dear Monsieur Burrows,

I understood from one of our recent conversations that you no longer wished to resume service at the Congo, and we seem to be agreed that a post suitable to your capabilities would be very difficult to find in Africa. You must not, however, conclude, that we can have no further need of your services should an occasion arise for special missions, such as may arise at any moment in other districts. If you were disposed to hold yourself at our disposal to that end, I should be obliged if you would let me know.

Yours truly,

In the name of the Secretary of State,

The Secretary-General of the Department of the Interior,

Liebrechts.

London,

December 31st, 1901.

Dear Monsieur Liebrechts,

I do not remember the conversation, alluded to in your letter of the 21st December, in which I said quite plainly that I no longer wished to resume service at the Congo. I understood that it was a question of the condition under which it would be impossible to resume such service. You ask me if I am disposed to hold myself at the disposal of the State, with a view of being employed "by special missions which may arise at any moment in other districts." Am I to understand that I am still in the service of the State or not? And if so, under what conditions of remuneration, etc.?

Yours truly,

G. Burrows.

\section{Congo Free State,}

Department of the Interior,

Brussels, January 2nd, 1902.

Dear Monsieur Burrows,

In reply to your letter of the 31st December, 1901, I hasten to inform you that your agreement ended with your return to Europe, 
and that since then you have, according to our laws and regulations, ceased to be a member of our staff. It is precisely for this reason that I asked you in my last letter if it would suit you to hold yourself at our disposal for a certain period-let us say two years. You will have to undertake during that period any missions with which we might entrust you. Of course, if you accepted this proposal, an annual salary would be allowed you for that period of two years. But before deciding this point I should like to know if, in itself, our proposal commends itself to you. I should be obliged if you would reply as soon as possible.

Yours faithfully,

Liebrechts.

The reader who can discern in the above letters any ground for the allegation that Captain Burrows is either a discredited or discharged employé must indeed be an imaginative person. He will rather be inclined to suspect the true inwardness of the last communication-to which, by the way, no reply was ever sentand to no longer wonder why the State has heretofore been so successful in eluding public criticism and all that it implies.

Of the author of that portion of the book which is entitled "A Campaign among Cannibals," I am able to speak from personal knowledge extending over more than twenty years. He had, prior to 1896 , the year of his appointment to the service of the Congo State, gained much experience in dealing with the savage tribes of the South and Western Pacific; and this doubtless obtained for him a cordial reception from a special commissioner despatched to the United States for the purpose of strengthening the commercialcum-military personnel of King Leopold's African Administration by the admixture of a number of young and adventurous Americans. In all, sixteen citizens of the Republic were engaged; of these, two handed in their resignations soon after arrival in Africa, nine were killed or fell victims to the climate, and two only-one of whom perished during his second term-returned to the Congo after the expiration of their contracts. Having completed his engagement 
with the State, during which period he was advanced in rank and stationed in the Province Orientale, the so-called Zône Arabe, in the far eastern portion of the kingdom, Mr. Canisius entered the service of the Société Anversoise du Commerce au Congo, the now notorious "Mongalla Concessionaires." Of his strange experiences in the capacity of agent for this company, the present volume bears abundant testimony. With his return to Europe in the summer of 1901, under circumstances set forth in Chapter XI., ended his connection with Congo State and companies-invalided, it is true, but certainly not discredited or discharged. In proof of this, it will suffice to quote the following correspondence :-

\section{Independent State of the Congo, Secretariat of State,} Brussels, April 4th, 1899.

Monsieur,

I have the honour to inform you that, by decree dated April 1st, 1899, of which I enclose duplicate, His Majesty the KingSovereign has been pleased, on my advice, to confer upon you the Star of Service. I send to you the insignia, of which I beg you to acknowledge receipt. You are authorised to carry the star, with one bar. Accept, etc.,

The Secretary of State,

Baron van Eetvelde.

Société Anversoise du Conmerce au Congo,

Monsieur Canisius, Monjoa, August 21st, 1900.

Agent in Monjoa,

I have the pleasure to express to you my great satisfaction with the courage of which you have given proof during the four months you have been at Monjoa. I congratulate you very sincerely, and I shall propose to the Directorate to present to you a bonus of 500 francs. Continue to give proof of the same courage, and the Society will be suitably grateful. Accept, my deàr M. Canisius, with my repeated felicitations, the assurance of my warmest esteem.

The Commercial Director in the region of the Budjas, H. van Eyken. 
INTRODUCTION.

\section{Independent State of the Congo, \\ Department of the Interior, \\ Brussels, September 30th, 1901.}

\section{Monsieur,}

I have the honour to acknowledge receipt of your letter of September 25th, and I regret to inform you that, in spite of mylively desire to oblige you, it is impossible to give a favourable reply to your request, no post suitable to your deserts being at present vacant. Accept, etc.,

\section{For the Secretary of State,}

The Secretary-General of the Department of the Interior,

Liebrechts.

It may be added that, immediately after receipt of $M$. Liebrecht's letter, Mr. Canisius accepted a position under an English Company in a British Colony, and that, in support of his successful candidature for this appointment, the Société Anversoise had forwarded the warmest possible recommendation.

It lies not within my province, nor, indeed, would the present place be appropriate, to refer at length to the contents of this volume, or the difficulties attending its publication. To certain circumstances, however, it behoves me to make more than passing allusion. For instance, it should be noted that there has been an absolute absence of collusion between the authors; that neither has had knowledge of the work of the other; that not a word has passed between them on the subject of this most novel collaboration. A not inconsiderable portion of the work results from persuasion on my part that the experiences related in it were of such a character as to more than justify a maiden literary effort; and I am not without hope that the verdict of readers will go far to confirm this opinion. The chapters referred to are a plain unvarnished tale of personal observation and adventure, evidencing, however, at the same time, no small measure of well-balanced judgment. For its actual form I may, in a measure, be held responsible; but I trust that, in passing through my hands, the 
narrative, has lost nothing of inherent freshness and fascination. Captain Burrows can very legitimately claim larger literary experience. It is, therefore, mainly because I judged it expedient that I have, with his full knowledge and cordial concurrence, ventured to modify in larger degree than I personally would have preferred, his work, as originally planned and completed. The volume, as a whole, may lack much in finish and arrangement, and fail, for other reasons, to satisfy even the least exigent of critics. For most faults, however, both of omission and commission, some extenuation can be urged; and therefore it is that I, not without hope of favourable response and on behalf of the respective authors, plead for the reader's most generous indulgence.

It were easy to have made this volume a catalogue of horrors beside which the most fiendish atrocities of heathen peoples and of semi-civilized misrule would have appeared relatively mild. Such, however, was at no time the intention of the authors. They desired rather to place on record events and conditions which, in different parts of the Congo State, had come under their personal observation. The instances of misrule and cruelty which are specifically noted in themselves make up a serious indictment; but I can readily believe, had the authors willed, that reference to events which are beyond dispute, but which they were spared the pain of witnessing, would have made it still more terrible. As it is, many pages and even chapters have been omitted from the original manuscript, not because I failed to attach absolute credence to the facts therein contained, but for the simple reason, to bluntly put it, that they were "unfit for publication" in a work destined for general circulation. It may be that I have, by these expurgations, somewhat weakened the effect of the volume, especially as the most serious charges were justified by a mass of incontrovertible evidence which can, at any moment, be produced. 
It has been a frequent vaunt of defenders of Belgo-African rule that, given reliable data and specific charges of cruelty and illtreatment, the Congo authorities would at once institute such proceedings against the offenders as would convince the world of the sincerity and humanity of the King and his advisers. For redeeming these oft-repeated and grandiloquent pledges, the present volume appears to offer many excellent opportunities. Should the accusations therein be considered of insufficient gravity, the Administration of the State may be reminded that inquiries have yet to be held into other long series of offences, and that many, perhaps the majority, of the persons implicated are still basking in the sun of royal or administrative favour. It is not, however, against individuals that this book is directed; for persons have been but the instruments of a pernicious system, the more vicious because cloaked in cant and hypocrisy. To expose the real purposes of the system, to strip from it the deceitful trappings of religion and philanthropy, to free Britain from the disgrace of complicity-these are the objects of the movement to which this book may lend some aid.

If King Leopold and his advisers had been actuated by one tithe of the good intentions which they so loudly profess, inquiry would long since have taken place into the instances of maladministration from time to time brought under their notice by scores of honourable authorities. They have not even the excuse that all the latter are prejudiced foreigners, for more numerous than the other travellers and missionaries who might be mentioned in this connection are the Belgians who have offered evidence of wrong-doing, and sought to relieve their country from the shameful stain of complicity. It is an insult to common, sense to argue, in extenuation of facts which cannot be denied, that certain alleged culprits have been prosecuted and punished. Certain unfortunate non-commissioned officers and clerks have 
occasionally been offered up as sacrifices to outraged public opinion; but what of the higher officials who instigated the offences, or connived at them wilfully, or by neglect of proper supervision of their subordinates? Even when prosecutions have taken place, the punishment inflicted upon persons convicted by the State Courts has been little better than a farce; hard labour, so-called, has consisted of confinement in the fort at Boma, with practically nothing to do. After a time, the prisoners, being an expense to the State, and bringing no profit to the coffers of the philanthropic Government, are shipped off to Belgium or conveniently suffered to "escape." Consequently, a sentence of ten years' penal servitude really means from eighteen months to two years' nominal imprisonment-nominal because the majority of the prisoners, having had the training of clerks, are throughout the day employed in the Government offices. Even in the luncheon hour they are permitted to take their repast in the same hotel as the other officials.

Concerning the average treatment of the hapless natives of the rubber-producing regions of the Congo, a very fair idea may be gathered from the following pages. Other offences, however, have been committed, which not even greed for commission can excuse. Of these a terribly long list could be compiled from documentary and other evidence now lying before me. For present purposes, however, it must suffice to mention but a few examples, premising that in a majority of instances the facts must be notorious to the authorities in Boma-if not at Brussels.

From the region of the Upper Uelle, which, by the way, is included in the Domaine Privé, come many scandalous and well-authenticated stories of Belgo-Congolese barbarity. At M'Bima, on December 30th, 1894, a man was shot for attempting to escape from the station. It was, at this post that a former 
commandant had amused himself by boring holes, with the aid of his revolver, through the lobes of the ears of natives. On March 26th, 1896, at the station of Pokko, on the Bomakandi River, a woman prisoner attempted to escape to her own village. She was recaptured not far from the post, and brought back and shot, her only crime being that of trying to gain her freedom and return to her family. On October 26th, in the same year, another woman was shot at the post of Amadis for an identical offence, and the garrison and workpeople were given a holiday to celebrate the event. On November 16th following, two natives, who had crossed the river near the post of Suruango were, upon the hearsay evidence of local soldiers, summarily executed. Their goods, women, and all the property they possessed were seized and forthwith confiscated. The officer responsible was afterwards tried by court-martial for abstracting a demijohn of wine from the transports passing his post, and for insubordination. The various offences were brought to the notice of the authority competent to decide upon the trial of the officer; but the charges of murder were suppressed, and the offender was sentenced to one month's penal servitude-i.e., office work with other Europeans in the district commissioner's office-on the other two counts. A little later the man was pardoned, decorated, and promoted to the command of the post of Dongu, where, on August 6th previous, his predecessor had caused a native child to be thrown into the rapids because the infant had been afraid to leave its parents' hut during the night. The sentence was carried out, and the gallant officer proceeded to the river-bank, with the remark that "they would see if the little devil could swim." In the previous April, the same officer had shot five native women nominally in the employ of the State-that is to say, prisoners taken in punitive or rubber-gathering raids-because, forsooth, they had attempted to escape from his station, preferring to risk the dangers which 
they might encounter among the native surrounding tribes to remaining victims of the native soldiers employed at the post. The soldiers who brought back the women informed the lieutenant that unless the culprits were executed they would certainly again desert, whereupon, with the officer's knowledge and consent, the five women were placed kneeling on the banks of the river and shot.

On June 5th, 1896, the chief of the station of N'yangara shot an old native man who had been captured near the post, and who was suspected of trying to steal from the station. There was no attempt at a trial, nor was any report made of the circumstance. In March and April of the same year a punitive expedition left Nyangara, under the command of a district commissioner, to punish the Dzande chief N'doryma, north of the river, who had been guilty of massacring two white men and fifty native soldiers stationed near his village. Before leaving, the commissioner asked Captain Burrows to procure from the native Mangbettou chiefs, on the south side of the river, a number of native warriors to accompany the expedition. These were obtained, subject, however, to a strict understanding with their chief, Toli, that the men, who were high-caste tribesmen, should only be employed for fighting purposes, and not be required to act as porters to the column. Four days out the column was attacked by the Dzande, who were easily repulsed, leaving several scores of dead on the field. The following morning the native contingent under Toli, who had behaved well during the engagement, were told that in the future they would be required to act as porters to the expedition. The Mangbettou chief, having in vain expostulated against this breach of agreement, subsequently left the camp with all his men. Although this in no way endangered the safety of the column, which consisted of 500 rifles, its gallant commander forwarded immediate orders to N'yangara that the chief's village and crops should be 
destroyed, his women taken prisoners, and the chief himself captured and placed in chains. The reason given for this glaring breach of orders, issued by the Governor-General, forbidding the burning of native villages even in time of war, was not, as one might naturally think, the crime of desertion, but that the tribesmen had taken with them on leaving the camp several corpses of the enemy slain on the previous day. Yet it is notorious that the Congo native troops were living for the most part on the flesh of prisoners taken on the road and on the corpses of the Dzande people killed in the skirmishes. To another occurrence in connection with this expedition reference may be made. A woman and infant captured in the bush were brought into camp and taken before the commander and his Belgian staff. The mother threw herself on her knees before these so-called Christians, beseeching that, though she should be killed, the life of her infant might be spared. However, at a sign from the leader of the expedition, a Mobangi soldier took the child from its mother, and, holding it up by one leg, disembowelled and afterwards cut its throat before the eyes of the wretched mother, who in her turn was murdered and very probably devoured by the soldiers.

Lower down the river, at the post of Djabbir, in February of the same year, eleven women prisoners were, by order of the commandant, made to work in chains, carrying sand and earth a distance of some two hundred and fifty yards from a garden which he was making to the river-bank. The European non-commissioned officer who was detailed to superintend the punishment received strict orders from the commandant that the women were not to be allowed to walk; that the whole of the work should be done running; and that native soldiers with sticks should accompany them on each journey. Of these women, one gave birth to an infant; but this did not procure for her any reduction of punishment. She, and indeed the other ten, died very shortly 
afterwards. On November 30th, at the post of Uerre, a young girl in the service of a Belgian sergeant was flogged in public by his orders. The man who administered the flagellation after a short time refused to continue the operation, whereupon the sergeant produced his revolver and threatened to shoot him. When the flesh had been cut into ribbons, the girl was tied to a flagstaff in the centre of the station. The sergeant then procured some native honey, and with his own hands covered portions of the girl's body with the substance, and she was left in the burning sun without anything to sustain her during a whole day. In the evening, the sergeant was warned that if the girl were not released and given food and water she would certainly die. It was not, however, until the following day that the woman was freed from her bonds and taken to the native quarters, where she died the same night. A Belgian doctor, who had just arrived at the post, saw her when at the point of death and beyond all medical aid, but made no report to the authorities of what he had seen and heard.

Of the many cruelties practised or permitted by the notorious Major Lothaire, instances could be given without number. A few will suffice, some of which can be substantiated by photographs. On October 7th, 1895, at Lusuna, Lothaire, then in command of an expeditionary column against the revolted Batatelas, detained some four hundred men, women, and children who came in with the intention of placing themselves under his protection. Of this number four chiefs and twenty-six men were selected and foully murdered. Two of the chiefs-as shown in the illustration reproduced from a photograph which appears elsewhere in this volume-were tortured in a fashion so cruelly diabolical that it is scarcely possible to believe that it could have been the outcome of a white man's brain. To a cross pole, run along three upright posts put in the ground, the wretched victims 
were suspended by cords attached to the neck, the middle, and the feet. A doctor, in the presence of Lothaire and the other Europeans accompanying the expedition, then proceeded to remove the scalps of the tortured men. His black assistant also, by order of the doctor, amused the white spectators by sawing through the shinbones and cutting off the victims' noses and ears. These proceedings lasted for about an hour, when the wretched men were cut down, handed over to the tender mercies of Lothaire's soldiers, and thrown into the bush. Eight days later, two men and a woman were taken prisoners and brought into Lothaire's camp. The men were first compelled to outrage the woman in the presence of the white men and the soldiers, and then hanged, heads downward, from the branches of a tree in the camp. The rope was, in each case, tied to one ankle, a cord having been previously twisted around the big toe. While in this position the victims were subjected to every indignity which the native mind could conceive. During the night one man managed to release himself, but was retaken, and again hung up in the manner described. Once more he escaped, and was again retaken; but this time Lothaire graciously granted him his freedom. The other man and the woman were, however, beaten to death by the soldiers during the following morning. A fortnight later, while the expedition was in camp near N'gandu, on the Lomami River, a dozen men and women were captured by the soldiers and brought before Lothaire, who said, curtly enough, "Take them away." They were then removed by the soldiers about fifty yards outside the camp, and butchered with small knives. The wretched people offered no resistance to the murderers, but stretched themselves on the ground and awaited the thrust of the knives with fixed stolidity. Their corpses were afterwards passed as food to the native auxiliaries. On November 27th, in the same year, Lothaire handed over to his soldiers a score of prisoners. The men were 
conducted to the parade ground, where they were massacred by the soldiers, armed with bludgeons, in the presence of Lothaire and all the other Europeans.

At Stanley Falls, on August 28th, 1895, two men were arrested a short distance beyond the station on suspicion of having indulged in cannibalism. A corpse had been found in the bush, but without any traces of violence upon it. On the strength of this fact, the Belgian officer commanding the post ordered the prisoners to be put in chains, and a leg cut from the corpse to be tied round each man's neck. The men were then exposed to the fierce rays of the sun in the centre of the station, without either food or water. That this outrage actually occurred is attested by photographs appearing on pages 252 to 255. At Basoko, the headquarters station of the district of the Aruwimi, women used to be flogged almost daily for the most trivial offences. In one case five women were beaten for daring to go to a village a short way up the river to buy food without having previously informed the commandant. During his usual morning walks this "sportsman" was accompanied by a bearer carrying a shot-gun, and if, in response to his repeated calls, the natives refused to come forward to greet him, he would open fire upon any unfortunate men or women who happened to be within easy range. In such detestation was this man held by the natives that they firmly believed that he had kept a native woman in confinement to fatten up, and that he had caused her to be killed and prepared for the table in order that he might experience the sensations of cannibalism. In November, 1897, the same man journeyed up the river to the station of Yambuya, near which was the village of a chief named Likombe, who, owing to some trouble in the collection of rubber, had refused to trust himself to the tender mercies of the white men. On the arrival of the steam launch, the villagers, as was usual, came down to the bank to supply wood. They 
were induced by the two Belgian officers on board to carry a message to Likombe to the effect that if he cared to appear no harm whatever would befall him. The spirit in which this pledge was given may be gathered from the sequel. As soon as Likombe came on board, the vessel was cast off under steam, and the man was seized and chained to the smoke stack. When, later in the day, this victim of treachery arrived at the post of Basoko, his face and part of his body had been par-baked by contact with the heated metal, and he was suffering severely from brutal attacks made upon him by his two black guards. Nevertheless, he was at once placed in prison, where he died two days afterwards. On another occasion, at Yandumba, because the natives who had come down to the river-bank, bringing wood for the steamer, did not work fast enough to please him, the same Belgian officer, without warning, ordered his men to fire into the crowd, with the result that a man and a woman were killed. These and other exploits were eventually rewarded by a grateful Sovereign with augmentation of pay and the Order of the Crown.

It would be improper to allow it to be supposed that there has been a general absence of reports to the authorities, drawing attention to proved instances of official misconduct and illtreatment of the natives. Such is by no means the case. To the headquarters of probably every district of the Free State have been sent, at different times, documentary evidence attested by responsible and conscientious officials, of events which no government worthy of the name could afford to pass unnoticed. In a few instances, receipt of these reports has been followed by inquiry into the matters complained of, and sometimes punishment has overtaken minor offenders; but as a general rule the only sufferers have been the honest and well-meaning officials who have deemed it their duty to bring to their immediate superiors, 
or the authorities at Boma, knowledge of the existence of evil. There are before me, as I write, abstracts or copies of several such reports; and it would be interesting to know what action, if any, was taken by those responsible for further investigation. In one document to which attention may be directed, a Belgian medical officer, attached to the district of the Aruwimi, reported that he had examined into the case of five women, workers at the post of Mogandjo; that all had been seriously injured by blows from a stick, and that the person responsible for the outrages was a sous-intendant whom he mentioned by name, and who, it may be added, is alleged in other communications to have been guilty of more serious offences.

"My only wish is that the truth shall always be stated about my Congo Administration. This is the chief reward I shall look forward to for all my efforts." Thus spoke Leopold II., King of the Belgians and Sovereign of the Congo State, on January 6th, in response to an address presented to him by the Committee of the British Baptist Missionary Society, in grateful acknowledgment of His Majesty's "enlightened rule" in Africa. Not the least conspicuous participator in this remarkable demonstration was Sir Hugh Gilzeau Reid, ex-M.P., newspaper proprietor, ex-President of the Institute of Journalists, officer of the Order of Leopold, and Knight Commander of the Order of the Crown. Not many days after this gentleman's return from Brussels, there appeared in many English newspapers communications from his own pen in which, while declaring unswerving adherence to former statements of his own in defence and eulogy of the Congo Administration, he darkly hinted at certain charges "now, for all practical purposes, sub judice," which, in his opinion, justified a demand for the suppression of all criticism not favourable to the State. To persons less familiar with the circumstances than Sir H. Gilzeau Reid, the present writer, and others, these utterances must have 
appeared of somewhat cryptic character. They, and the proceedings referred to, were the answer of the Sovereign and Administration of the Congo to the announcement of the present volume-the crowning evidence of their much-vaunted desire to arrive at the truth and ensure equitable treatment of the peoples committed to their care.

England is the most hospitable of countries. Under the British flag all men, subjects of the Crown or aliens owing allegiance to other States, possess almost equivalent rights. Even her Courts are freely open for the redress of grievances, irrespective of the nationality of the litigants. Of all these things we are justly proud, and this notwithstanding, or perhaps because of, a comparative absence of reciprocity on the part of other peoples. Our hospitality, however, was never intended to serve as a weapon wherewith an alien Government might strike at treasured rights long endeared to us. It is a common allegation abroad that the British nation of late years has abandoned not a few principles for which our forefathers fought and bled. Be this as it may, there are some rights for the maintenance of which few Englishmen would deem any sacrifice too great, and notably among these are freedom of speech and writing. Secure from any possible curtailment of these privileges by either Crown or Parliament, it has been reserved for the Administration of the Congo State to threaten us with their complete extinction. By setting in operation the machinery of our own tribunals, this alien Government, of not unblemished record, has sought to protect itself from criticism cheerfully faced by the highest of our national institutions. It has asked for a legal injunction against the publication of the present volume, and claimed, pending this triumph of state-craft, that no adverse reference to its misdeeds shall be permitted throughout the length and breadth of England. Yet at the same time there are appearing 
in the Press of Belgium and other countries obviously inspired communiqués, against the falsity of which there is practically no redress. There are few Englishmen, I venture to think, who will not agree that the Congo Administration might be better employed in putting its own house in order than in seeking to deprive citizens of other nations of rights which their own Governments would certainly never venture to assail. It has long been matter for painful reflection that England and the United States should be prominent among the nations responsible for the very existence of the Congo State and the perpetuation of its scandalous rule; and I cannot for a moment doubt that these generous sentiments will be materially strengthened by the strange and, happily, very novel proceedings to which I have referred.

MANOR PARK,

JOHN GEO. LEIGH.

LEE, Kent,

28th February, 1903. 






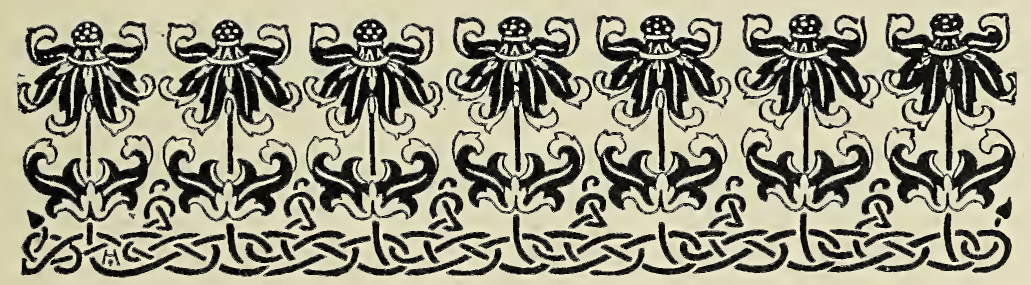

LIST OF ILLUSTRATIONS.

PAGE

Frontispiece : The Author

Dedication : Leopold II., King of the Belgians, Sovereign of the Congo

Free State

Torturing Native Chiefs (from Original Photograph) .. Next to Introduction
Do.
do.
(Enlargement)
do.

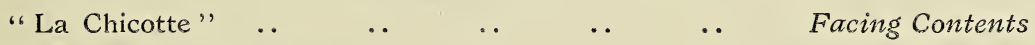

A Group of Belgian Officers $\quad \ldots \quad$. $\quad \ldots \quad$.. $\quad$. Next to Contents

Group of Officials, Congo Free State $\quad \ldots \quad \quad \ldots \quad$ Facing Page I

$\begin{array}{llllllllll}\text { Banana } & \ldots & \ldots & \ldots & \ldots & \ldots & \ldots & \ldots & 2\end{array}$

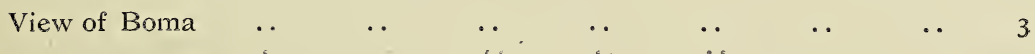

$\begin{array}{llllllllll}\text { Matadi Post } & \ldots & \ldots & \ldots & \ldots & \ldots & \ldots & \ldots & 6\end{array}$

$\begin{array}{lllllllll}\text { A Street in Matadi } & \ldots & \ldots & \ldots & \ldots & \ldots & \ldots & 7\end{array}$

$\begin{array}{llllllllll}\text { Market } & \ldots & \ldots & \ldots & \ldots & \ldots & \ldots & \ldots & \end{array}$

$\begin{array}{llllllllll}\text { Canoes Racing } & \ldots & \ldots & \ldots & \ldots & \ldots & \ldots & \ldots & \text { ro }\end{array}$

$\begin{array}{lllllll}\text { Deformed Native Woman } & \ldots & \ldots & \ldots & \ldots & \ldots & \text { II }\end{array}$

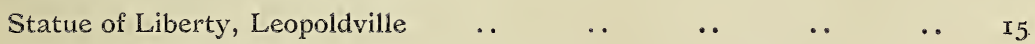

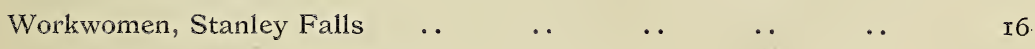

$\begin{array}{llllllllll}\text { Stanley Falls Station } & \ldots & \ldots & \ldots & \ldots & \ldots & \ldots & \text { I7 }\end{array}$ 


\section{LIST OF ILLUSTRATIONS-contd.}

Tippoo Tib's Old House at Stanley Falls

Market, Stanley Falls $\quad \ldots \quad$.

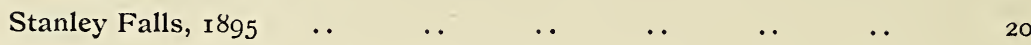

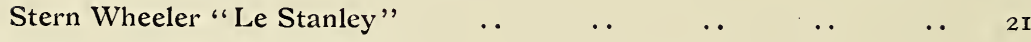

$\begin{array}{lllllllll}\text { Bumba } & \ldots & \ldots & \ldots & \ldots & \ldots & \ldots & \ldots & 24\end{array}$

$\begin{array}{llllllllll}\text { "Barumbu" } & \ldots & \ldots & \ldots & \ldots & \ldots & \ldots & \ldots & 25\end{array}$

$\begin{array}{lllllllll}\text { A Native Band } & \ldots & \ldots & \ldots & \ldots & \ldots & \ldots & 28\end{array}$

$\begin{array}{lllllllll}\text { Women Prisoners } & \ldots & \ldots & \ldots & \ldots & \ldots & \ldots & 29\end{array}$

$\begin{array}{lllllll}\text { Bolobo Mission Station } & \ldots & \ldots & \ldots & \ldots & \ldots & 32\end{array}$

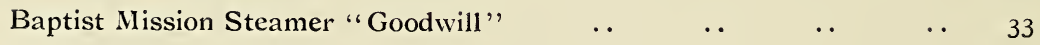

$\begin{array}{llllllll}\text { Natives bringing in Food } & \ldots & \ldots & \ldots & \ldots & \ldots & 34\end{array}$

Native Waifs and Strays at R.C. Mission at Ibembo $\ldots \quad \ldots \quad \ldots \quad \ldots \quad \ldots \quad 35$

$\begin{array}{llllllllll}\text { Pay-Day } & \ldots & \ldots & \ldots & \ldots & \ldots & \ldots & \ldots & 36\end{array}$

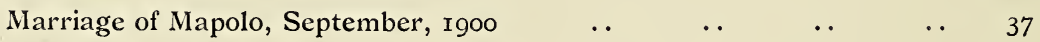

$\begin{array}{lllllllllll}\text { A Capita } & \ldots & \ldots & \ldots & \ldots & \ldots & \ldots & \ldots & \end{array}$

MM. Favarjer, Paulus, Birardi, Valkener, and the Author $\quad \ldots \quad \ldots \quad 40$

$\begin{array}{lllllllll}\text { Homeless Orphans } & \ldots & \ldots & \ldots & \ldots & \ldots & \ldots & 4 \text { I }\end{array}$

$\begin{array}{llllllllll}\text { Native Paddlers } & \ldots & \ldots & \ldots & \ldots & \ldots & \ldots & \ldots & 44\end{array}$

$\begin{array}{llllllllll}\text { Natives Embarking } & \ldots & \ldots & \ldots & \ldots & \ldots & \ldots & 45\end{array}$

$\begin{array}{lllllllllll}\text { Bangala Women } & \ldots & \ldots & \ldots & \ldots & \ldots & \ldots & \ldots & 47\end{array}$

$\begin{array}{lllllllllll}\text { Natives } & \ldots & \ldots & \ldots & \ldots & \ldots & \ldots & \ldots & & 50\end{array}$

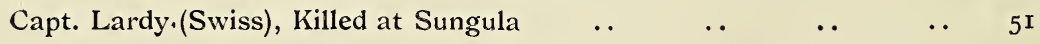

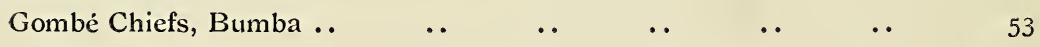

$\begin{array}{llllllllll}\text { Rubber Shed } & \ldots & \ldots & \ldots & \ldots & \ldots & \ldots & \ldots & 54\end{array}$

$\begin{array}{lllllllllll}\text { Drilling } & \ldots & \ldots & \ldots & \ldots & \ldots & \ldots & \ldots & & 55\end{array}$

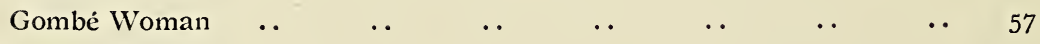

$\begin{array}{lllllllll}\text { Edgar Canisius } & \ldots & \ldots & \ldots & \ldots & \ldots & \ldots & 62\end{array}$

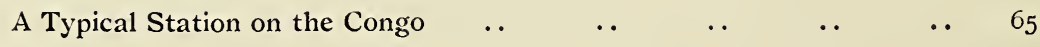

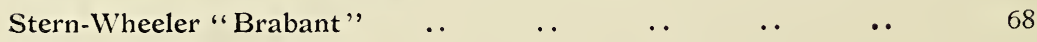

$\begin{array}{lllllllllllllllll}\text { Bangala } & \ldots & \ldots & \ldots & \ldots & \ldots & \ldots & \ldots & \ldots & & \ldots & 7 \text { r }\end{array}$

$\begin{array}{lllllll}\text { Major Lothaire and his Officers } & \ldots & \ldots & \ldots & \ldots & 73\end{array}$ 


\section{LIST OF ILLUSTRATIONS-contd.}

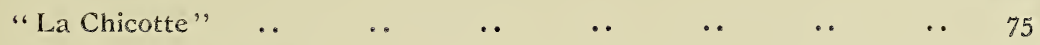

$\begin{array}{lllllllll}\text { Collecting Palm Wine } . . & \ldots & & . & & \ldots & \ldots & \ldots & \end{array}$

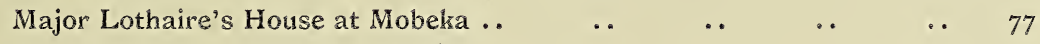

$\begin{array}{lllllllll}\text { Canoe Travelling } & \ldots & \ldots & & . & \ldots & \ldots & \ldots & 82\end{array}$

$\begin{array}{llllllllll}\text { House Building, Bumba } & \ldots & & \ldots & & \ldots & \ldots & \ldots & \ldots & 83\end{array}$

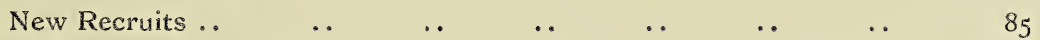

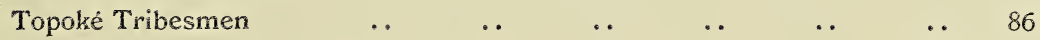

$\begin{array}{llllllll}\text { Topoké Cannibal Chief with Skulls } & \ldots & \ldots & \ldots & \ldots & & 87\end{array}$

$\begin{array}{lllllllllll}\text { "Turumbu" } & \ldots & \ldots & \ldots & \ldots & \ldots & \ldots & \ldots & 90\end{array}$

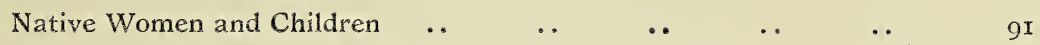

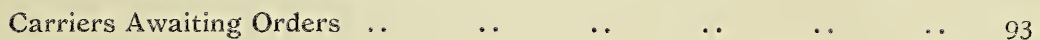

The Campaign against the Budjas (Sketch Map by Mr. Edgar Canisius) 98

$\begin{array}{lllllllll}\text { A Mogwandi Village } & \ldots & & \ldots & & \ldots & \ldots & \ldots & \end{array}$

$\begin{array}{llllllll}\text { A Trading Post } & \therefore & \ldots & \ldots & \ldots & \ldots & \ldots & \end{array}$

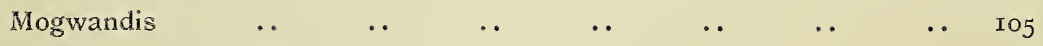

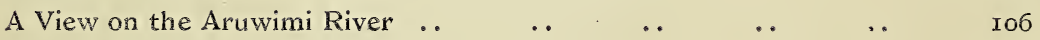

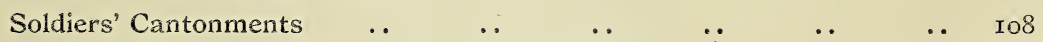

$\begin{array}{lllllllll}\text { Native Weapons } & \ldots & \ldots & \ldots & \ldots & \ldots & \ldots & \text { III }\end{array}$

$\begin{array}{lllllllll}\text { Soldiers' }^{\prime} \text { Quarters .. } & \ldots & \ldots & \ldots & \ldots & \ldots & & \ldots & \text { II }_{4}\end{array}$

The Rapids of Yambuya, opposite Starvation Camp $\quad \ldots \quad$.. $\quad$ II5

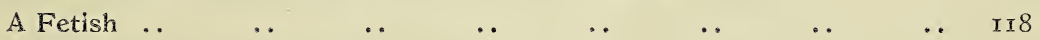

$\begin{array}{llllllll}\text { Group of Manyema Women } & \text {. } & & \text {. } & \text {. } & \text {. } & \text {.. } & \text { II9 }\end{array}$

$\begin{array}{llllllllll}\text { Prisoners .. } & \ldots & \ldots & \ldots & \ldots & \ldots & \ldots & \ldots & \text { I22 }\end{array}$

$\begin{array}{llllllllll}\text { Stanley Falls } & . & \ldots & \ldots & \ldots & \ldots & \ldots & \ldots & \mathrm{I} 23\end{array}$

$\begin{array}{llllllll}\text { Stockade and Blockhouse at Yalombo } & \ldots & & \ldots & \ldots & & \ldots & \text { I28 }\end{array}$

$\begin{array}{llllllllll}\text { Mobangi Chief } & \ldots & \ldots & \ldots & \ldots & \ldots & \ldots & \text { I29 }\end{array}$

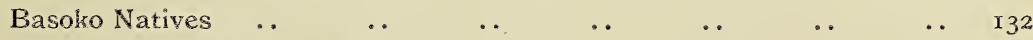

$\begin{array}{llllllll}\text { Gombé Woman and Child } & \ldots & \ldots & \ldots & \ldots & \ldots & \text { I33 }\end{array}$

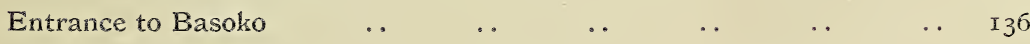

$\begin{array}{lllllllll}\text { Jo of Old Bassam } & \ldots & \ldots & \ldots & \ldots & \ldots & \ldots & \\ 137\end{array}$

Pigmy and Sheep Dog $\quad \ldots \quad$. 


\section{LIST OF ILLUSTRATIONS-contd.}

\begin{tabular}{|c|c|c|c|c|c|c|c|c|c|c|}
\hline Basoko Band .. & $\cdots$ & .. & $\therefore$ & & $\because$ & & .. & & .. & \\
\hline Workwomen in Brick & Sheds, I & Basoko & & $\therefore$ & & $\therefore$ & & .. & & \\
\hline Basoko Beach & $\therefore$ & $\therefore$ & $\ldots$ & & .. & & .. & & • & \\
\hline Basoko .. & $\therefore$ & .. & & . & & . & & . & & \\
\hline Monjou .. . .. & $\because$ & .. & .. & & $\cdots$ & & .. & & .. & \\
\hline Gombé from Interior & Aruwim & i District & & $\because$ & & .. & & .. & & \\
\hline Arabised Natives & $\because$ & .. & $\because$ & & $\therefore$ & & .. & & . & \\
\hline A Group of Soldiers & .. & .. & & . & & .. & & .. & & \\
\hline Boschoberri and Sub & Chiefs & .. & .. & & .. & & .. & & .. & \\
\hline Pigmy & $\because$ & .. & & . & & . & & .. & & - \\
\hline Bangala & $\cdots$ & $\cdots$ & .. & & .. & & .. & & .. & \\
\hline Barumba .. & .. & .. & & $\cdots$ & & .. & & .. & & \\
\hline cokandu Natives & .. & $\therefore$ & .. & & .. & & .. & & .. & \\
\hline
\end{tabular}

Basin of the Mongalla River and Territory conceded to the Société

$\begin{array}{llllll}\text { Anversoise du Commerce au Congo .. } & \ldots & \ldots & \ldots & \text { I66 }\end{array}$

$\begin{array}{lllll}\text { Lieut. Braeckman, in command of the Mongalla Expedition } & . & \text {. } & \text { I69 }\end{array}$

$\begin{array}{lllllllll}\text { Manyema Woman } & . & \ldots & \ldots & \ldots & \ldots & \ldots & \ldots & \end{array}$

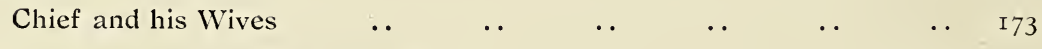

$\begin{array}{llllllll}\text { "Toby;" Sierra Leone Prisoner } & . & & . & & . & & \end{array}$

$\begin{array}{llllllllll}\text { Native Chief } & \ldots & \ldots & \ldots & \ldots & \ldots & \ldots & \ldots & \text { I } 80\end{array}$

$\begin{array}{lllllllll}\text { Body of a Murdered Woman } & . & & \ldots & \ldots & \ldots & \ldots & \text { I } 8 \text { I }\end{array}$

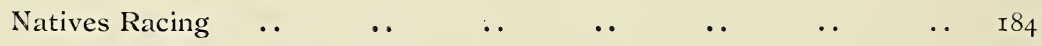

$\begin{array}{llllll}\text { Moimba Chief (who fought against Stanley) } & \ldots & \ldots & \ldots & \text { I } 85\end{array}$

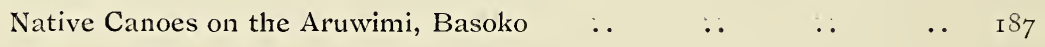

$\begin{array}{llllllll}\text { Hoffman's House, Basoko } & \ldots & & \ldots & \ldots & \ldots & \ldots & \end{array}$

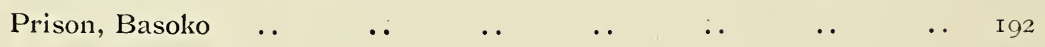

$\begin{array}{llllllll}\text { Interior of Prison, Basoko } & \ldots & & \ldots & \ldots & \ldots & \ldots & \end{array}$

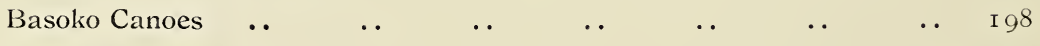

$\begin{array}{llllllllll}\text { Tower of Basoko } & \ldots & \ldots & \ldots & \ldots & \ldots & \ldots & & \text { I99 }\end{array}$

$\begin{array}{llllllllll}\text { River Front, Basoko } & \ldots & & \ldots & \ldots & \ldots & \ldots & \ldots & 20 z\end{array}$

$\begin{array}{lllllll}\text { Entrance from the River, Basoko } & \ldots & \ldots & \ldots & \ldots & 203\end{array}$ 


\section{LIST OF ILLUSTRATIONS-contd.}

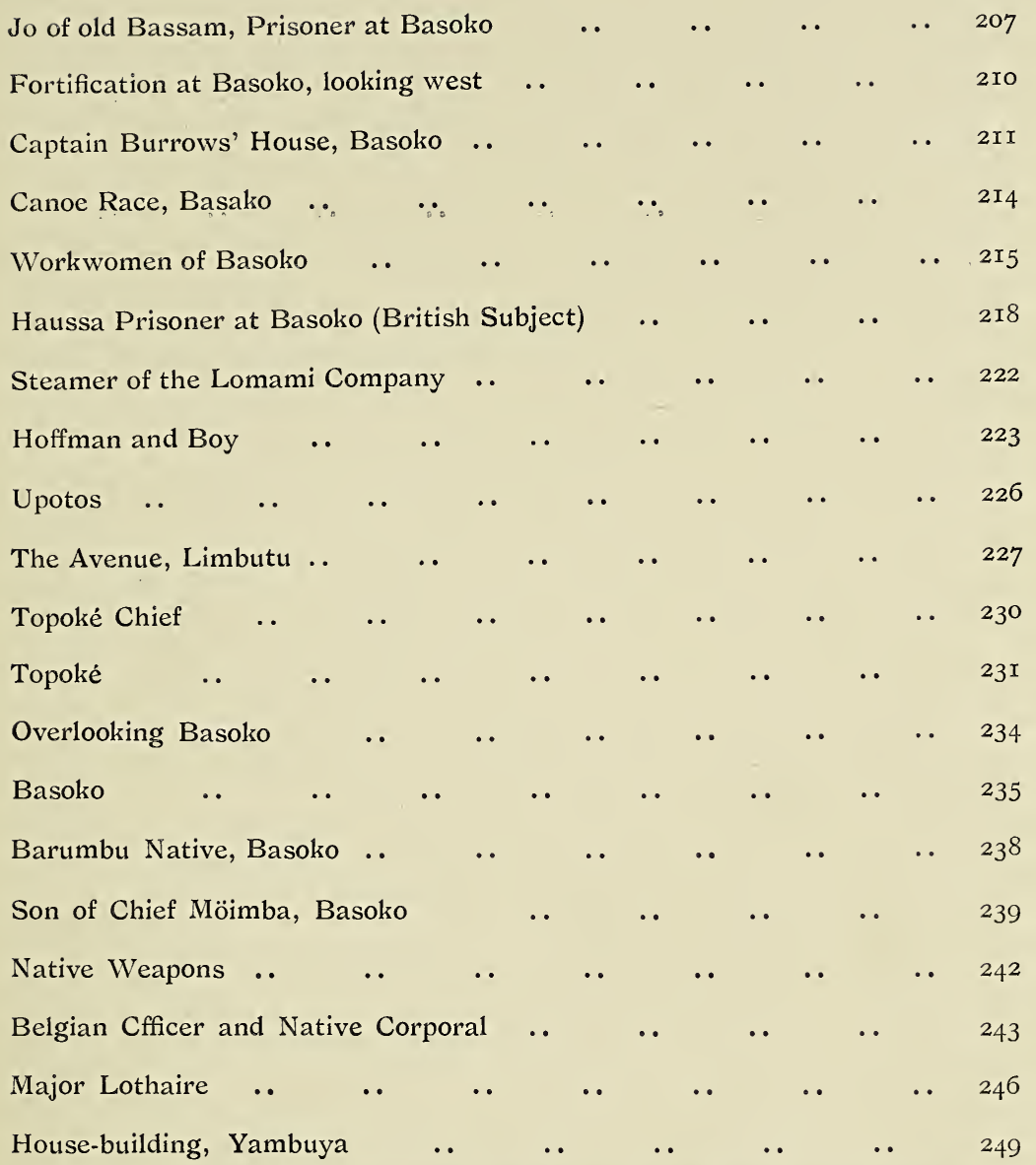

Prisoners in Chains, with portions of Human Body tied round their

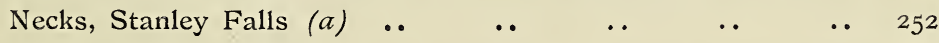

Prisoners in Chains, with portions of Human Body tied round their Necks, Stanley Falls. (From an Enlargement.) (b) ..

Prisoners in Chains, with portions of Human Body tied round their

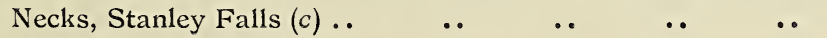

Prisoners in Chains, with portions of Human Body tied round their

Necks, Stanley Falls (From an Enlargement) (d) $\quad$.. $\quad 255$

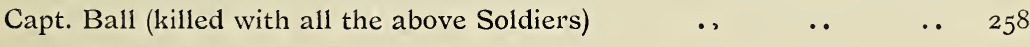

$\begin{array}{llllllllll}\text { A B Basoko Chief } & \ldots & \ldots & \ldots & \ldots & \ldots & \ldots & & 259\end{array}$

Flogging a Native with "La Chicotte" (From an Enlargement) . 26r 


\section{LIST OF ILLUSTRATIONS-contd.}

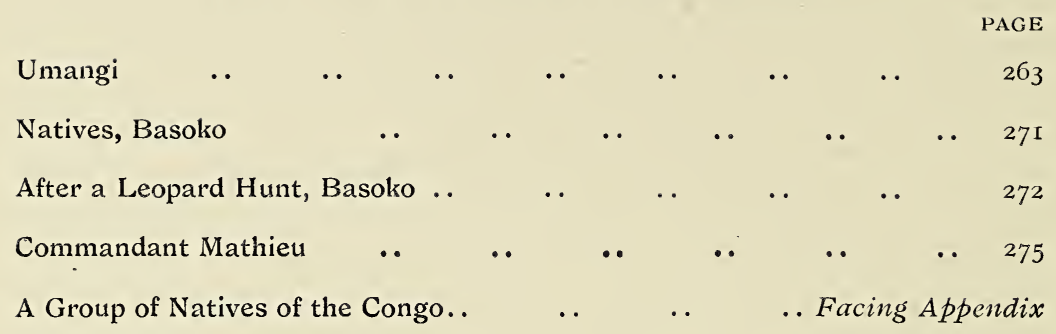




$$
\gamma
$$




\title{
CONTENTS.
}

\author{
CHAPTER I.
}

Return to the Congo-Opening of the Congo Railway-Arrival in Boma-The Great Fort-Big Guns-Story of the Bombardment of Boma-The Fort Evacuated-Capture of the Fugitives-A Man Hunt-Difference between the Congo of To-day and the Congo of I894-Progress and the RailwayThe Greater Number of Steamers-Railway Rates-Absurd ChargesThe British Consul's Protest-The Journey by Train-Bad and Expensive Accommodation-Leopoldville-Stanley's First Station

\section{CHAPTER II.}

A Long Stay at Leopoldville-A Desire to see Kinchassa-Recruits at WorkShooting-Practice-How They are Recruited-Views on SoldieringZandé Defiance-The Batatela-Mobangi-A Tale of Belgian TreacheryRetribution - An Alleged Voluntary System-Terms of Service-The Camps of Instruction-A Want of Forethought-Few complete their TermWood-Posts-The White Man's Word-A Drain on the Country-The $\begin{array}{lllllllllll}\text { Volunteers -A Different Footing } & \ldots & \ldots & \ldots & \ldots & \ldots & \ldots & \ldots\end{array}$

\section{CHAPTER III.}

Bolobo-Grenfell's Station - Missionary Difficulties - Life's Failures - The Wrong" Men "for the Work - State Methods - The Native Protection Commission-The Bishop's Prohibition-Sacredness of Rubber and IvoryEquateur-Workpeople and Recruiting-Punitive and Labour Expeditions-Terms of Service Unsatisfactory-Practically Slaves-A Slave's Return Home

\section{CHAPTER IV.}

The 'Trading Companies-Their Constitution Under the State--The Share the State Holds-Their.Objects-The Support they Receive from the StateTheir Troops - Their Officials - Their Liability to the District Commissioners-Responsibility to the Government-Their Relations to the Natives-Their Methods of Trading-How the Rubber is obtained-How the Ivory comes in-Do They go in for Anything Else?-Have They ever tried Mining?--Any Success?-What Chance of Profitable Gold Mining is there in the Congo?-Precious Stones-Attempts to Bribe State Officials-Cruelties on the Part of the Traders-Connived at by State Officials-Participated in-Proofs $\ldots \begin{array}{lllllllll} & \ldots & \ldots & \ldots & \ldots & \ldots & \ldots & \ldots\end{array}$ 


\title{
CONTENTS-continued.
}

\author{
CHAPTER V. \\ A CAMPAIGN AMONG CANNIBALS: THE RUBbER REgIME. \\ BY EDGAR CANISIUS.
}

Through the Lower Congo by Caravan Route and Railway-Boma and its Delights-The Matadi-Leopoldville Railway-The Steamers on the Upper Congo-A "Really Beautiful Yacht "-Callousness of the Belgo-CongoleseThe Mongalla Concession-Detained at N'Dobo-"Gathering" the Rubber - How the Natives are "tagged"—"La Chicotte" — Tapping the

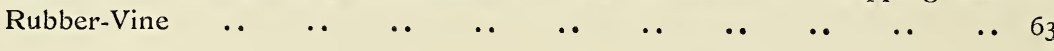

\section{CHAPTER VI.}

\section{THE REVOLT OF THE BUDJAS.}

A "Noble White Man "- The Congo at N'Dobo-Bad News from the InteriorThe Troops for "The Front"-Major Lothaire's Arrival-The Massacre at Bau-Our March against the "Man-Eaters"-The Budjas and their Country-Making a Stockade-A Night in the Forest-An Exhausting

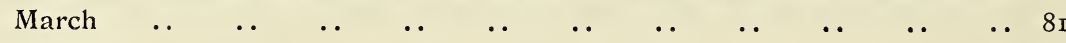

\section{CHAPTER VII.}

\section{THE MARCH TO YAMBATA.}

Precautions Against Attack-Budja Villages-The Dawn of "Civilization"Budja Ambuscades-"Kitchwa na Askari"-Arrival at Yambata-Description of the Post-Playing Tribe Against Tribe-The Belgians as ColonisersSome Traits of the Belgo-Congolese-My New Command $\quad \ldots \quad$.. $\quad$. 966

\section{CHAPTER VIII.}

\section{at YALOMBO.}

How War is Conducted in the Congo-Counting the "Bag "-Budja PrisonersA Motley Crowd-Attack on Yambata-A Wanton Murder-Major Lothaire's Responsibility-The Budjas and Their "Mono"-Arrival at Yalombo"Telegraphy" in the Jungle-Kumandungu Appears-Experiences at Yalombo .

\section{CHAPTER IX.}

\section{THE RETURN TO THE RIVER.}

Our Budja Babies-An Elephant Hunt-Kumandungu as Comedian-An Intended Feast and Its Sequel-The Massacre Near Yambinga-I Act as SurgeonSeven Tons of Human "Meat"-Yalombo Abandoned-Smallpox at $\begin{array}{llllll}\text { Monjoa-Again at N'Dobo-The Cost of the Campaign .. } & \text {.. } & \text {.. } & \text {. } & \text { I27 }\end{array}$ 


\title{
CONTENTS-continued.
}

\author{
CHAPTER X. \\ BELEAGUERED IN MONJOA.
}

My "Temporary" Command-The Commissariat Question-A Weary and Wearing Life-A Loquacious Garrison-Another Expedition Against the Budjas-My Soldiers Conspire to Kill Me-What the Expedition AchievedMoray as Accuser-The "Commissaire Royal"-Belgian Promises-The Attack on the Chef de Zone-Yamikele's Visit and Pleasant IntentionI Decide to Abandon the Post-A Sensational Denonement-The End of $\begin{array}{llllllllllll}\text { My Outfit .. } & \text {. } & \text {. } & \text {.. } & \text {. } & \text {.. } & \text {. } & \text {.. } & \text {.. } & \text {.. } & \text {. } & \text { I } 45\end{array}$

\section{CHAPTER XI.}

THE MONGALlA ATROCITIES: THE MASSACRE OF THE GWAKAS.

My Post at Akula-The Capita-Chiefs-Attack on Molendo-The condition of the Natives-Massacre of the Gwakas-Bartering with Human FleshThe State and "Atrocities"--Recruiting for the Force PubliqueDjabbir's Traffic-"Volunteering" in the Congo State-The African Negro as Soldier-Farewell to the Mongalla

\section{CHAPTER XII.}

\section{BELGIUM AND THE CONGO STATE.}

Baron Dhanis's Disclaimer-King Leopold as an African Pioneer-The International African Association-Sir H. M. Stanley's Exploit-King, France and Germany-The Berlin Conference-Belgium's Indifference-The Creation of the State-The King's Testament-Belgo-Congolese FinanceThe Relations of the Two Governments-Proceedings in the :Belgian

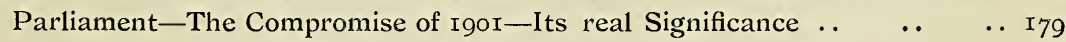

\section{CHAPTER XIII.}

\section{THE CONGO FREE STATE AND THE BERLIN CONVENTION.}

Prince Bismarck's Prayer-The Powers and King Leopold-The growth of Monopoly-Inception of the Concessionary Companies-Their relation to the State-Where Free Trade is not-The "Protection" of the Natives-

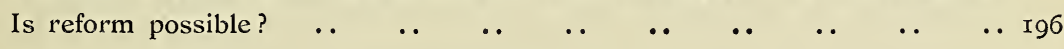

\section{CHAPTER XIV.}

\section{CIVILIZATION AND CANNIBALISM.}

Europeans in the Congo State-Missionary Efforts - The Chief, the Fetish Doctor, and the "Poison Proof"-A Gang of Cannibals-An Execution at Ponthierville-The Traffic in "Man-Meat"-The Fetish Power ..250 


\section{CHAPTER XV.}

The Natives in the Basoko District-Names of the Chief Tribes and their Customs-Burial; Marriage; Oracles-Fetish-Anthropology_LanguageWeapons - Customs in War - Cannibals - Feasts - Dances - Music History-Records

\section{CHAPTER XVI.}

METHODS OF WARFARE.

\section{CHAPTER XVII.}

THE STATE AS SLAVE-RAIDER.

An Expedition against the Batatela Nutineers-The "Nünchausen of the Congo"-The Fate of Lindsey Burke-The Balubas enslaved-Ilanga's Narrative-Ghastly Burdens-Murders on the March-The Slave System

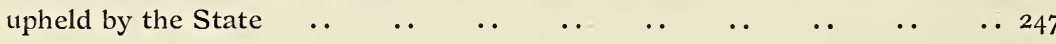

\section{CHAPTER XVIII.}

Isangi-A Pleasant Station-M. Baltus, Director of the Isangi Company-The Trouble with H. Hottiaux-His Revenge-His Departure-A Commission of Inquiry-I open a Court at Isangi-The List of Charges-Encouragement of Cannibalism-How he paid his Carpenters-Women in the Bush .. . . 262

\section{CHAPTER XIX.}

\section{THE STATE AND THE FUTURE.}

The Central and Local Governments-The Real Purport of the Codes-Some of the Judicial Dignitaries-To Right the Wrong-An Appeal to the Emperor William-Suggested Partition of the Congo Basin-Great Britain's Responsibility-The Question of the Bahr-el-Ghazel 


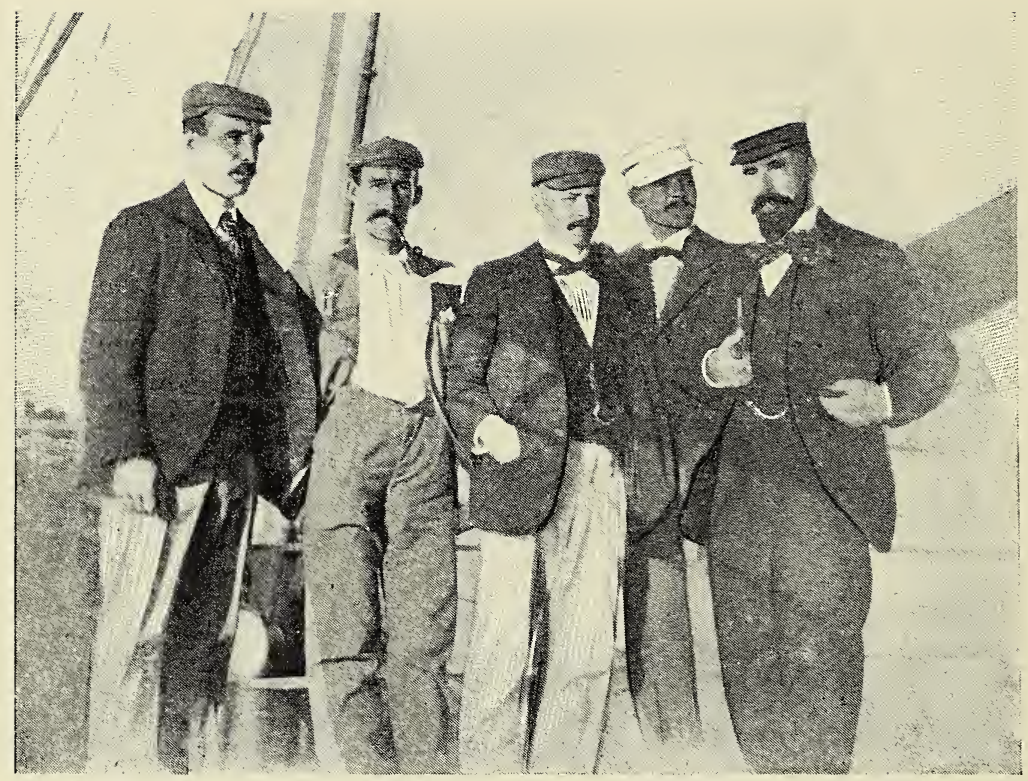

GROUP OF BELGIAN OFFICERS IN THE CONGO. 


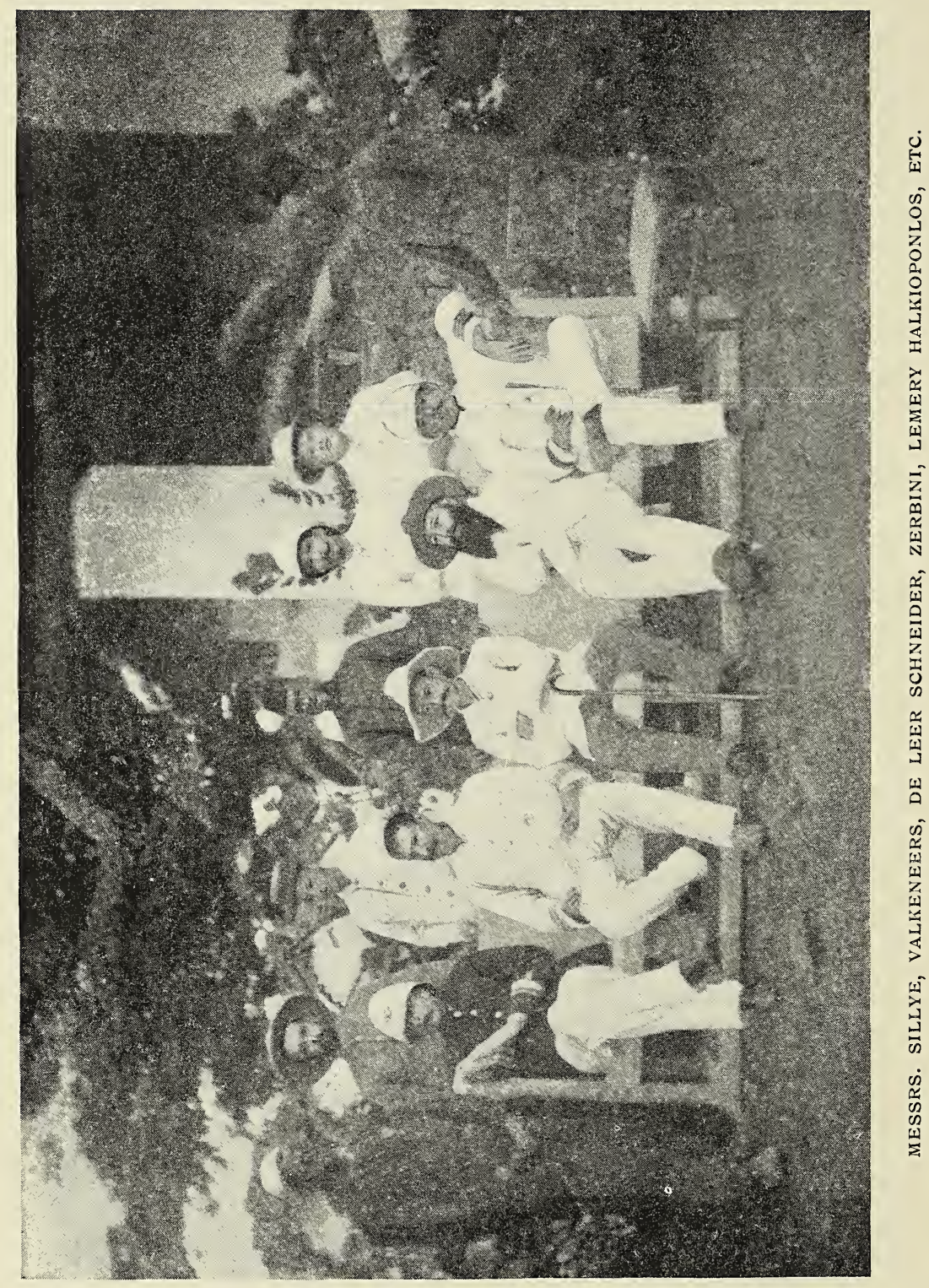




\section{CHAPTER I.}

Return to the Congo-Opening of the Congo Railway-Arrival in Boma--The Great Fort-Big Guns-Story of the Bombardment of Boma-The Fort EvacuatedCapture of the Fugitives-A Man Hunt-Difference between the Congo of To-day and the Congo of 1894 -Progress and the Railway-The Greater Number of Steamers--Railway Rates-Absurd Charges-The British Consul's ProtestThe Journey by Train-Bad and Expensive Accommodation-LeopoldvilleStanley's First Station.

Aт the expiration of a year's leave, most of which was taken up with curing and getting over attacks of hematuric fever, I left Antwerp on the 6th of June, 1898, to resume my duties as Commissioner of the Aruwimi district of the Congo Free State, whose commission I held.

At that time the railway from Matadi to Leopoldville was just about to be opened formally, and great festivities were in progress. The consequence was that the shipping was entirely disorganised, all the best boats being taken up by distinguished visitors to the opening ceremony of the railway. However, the old "Coomassie," of the Elder Dempster line, happening to be put on to relieve the traffic, I had to take my passage in her.

At the end of an uneventful voyage I arrived in Boma on the 2nd of July, but found that it was impossible to go up country at once, as the railway festivities were in full swing; so I spent an unwelcome but enforced fortnight in Boma, the seat of the Government. I made the best of the very indifferent accommodation I was able to find, and spent my time in exploring the place and the country round it. 
One of the most extraordinary sights in Boma is the great fort, which is situated just outside the town and commands it completely. It owes its origin to the Belgian officer Wangermée, who built it in 1893. It is constructed according to the latest rules of fortification, and upon its ramparts are mounted about eight guns-not the small kind of thing generally used in warfare against African natives, but great weapons of seven and nine inches pattern. Why it was built is more than I can say, or who the Belgians fear so much that they think such a fort necessary, or what its value is beyond that of ornament. At all events they have not yet got any practical value out of it, and to a certain extent they have suffered moral if not material damage

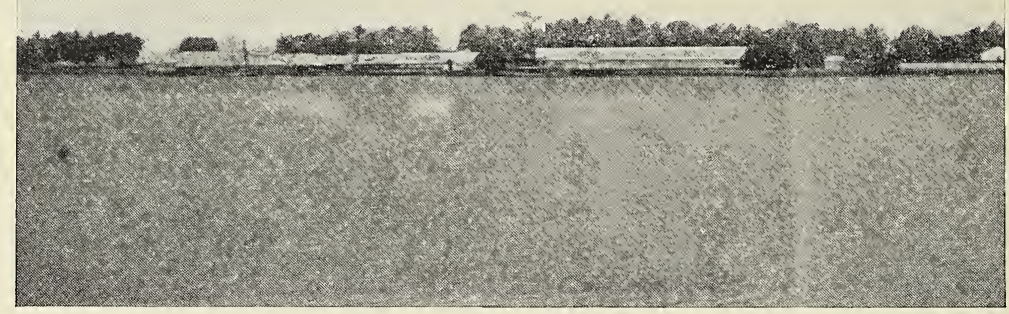

BANANA.

on its account; for the only time it was ever used it was turned against themselves.

This is rather an interesting story, and, so far as I know, was never told in the English papers. Marvellous tales about the Congo appear from time to time; but the real truth, which is often as strange as the wildest fiction, never gets beyond the country except through the garbled official reports. This particular story which I am going to tell refers to the bombardment of Boma, and is, in a manner of speaking, a piece of unrecorded history.

It was in 1900 that it happened. The greater part of the State garrison at Boma consisted of a troop of about 200 soldiers drawn from the Lake districts of Tanganyka and Manyema. These 
soldiers had completed the seven years for which they had undertaken to serve the State, and had made frequent applications to be repatriated, which was part of their bargain. No notice, however, was taken by the State authorities of their perfectly legal demands, and the men began to imagine that the Government intended to break the contract and keep them there indefinitely. The result was open revolt, and the men took the matter into their own hands. On the 19th of April, 1900, at two o'clock in the afternoon, they paraded at the fort in the usual manner. The only white man present was a Spaniard, who was employed at the fort as a mason. Their officers, who ought to have been present at the parade, had left the matter to the black sergeants, and had asked

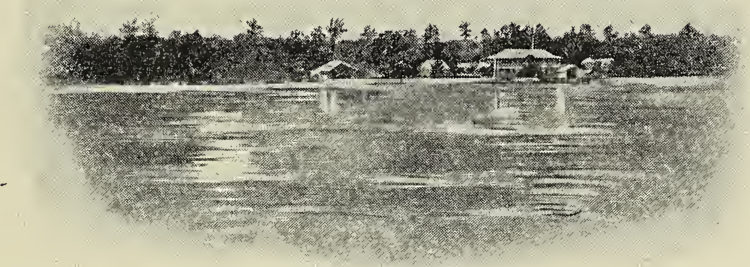

VIEW OF BOMA.

the Spaniard to keep an eye on things. The sergeants, of course, were in sympathy with the men, and the Spaniard for his pains was quickly killed. The natives then shut up the fort, and began to bombard the town to the best of their ability.

Fortunately, though they had been trained in the use of the guns, the sighting of them had not formed part of their instruction, and their shots went very wide of the mark. Another very fortunate matter was that they did not understand the ignition of the fuses, and consequently the shells could not explode. But seven and nine inch shells hurtling through the air are not any too pleasant for a powerless town, and the native soldiers succeeded in giving the Government at Boma a very bad fright indeed. The whole white population of the town was at 
once put under arms; but, of course, they dare not attempt to assault the fort. The soldiers were thus able to keep up the bombardment for two whole days, while Boma quaked in its shoes. Then, in the night, they evacuated the fort and started off northward over the hills, in a vague hope of finding their way back to their homes. This would in any case have been impossible, for they would somewhere or other have been shot in the bush and eaten; they were, however, quite willing to take the chances. Nineteen of them were captured before they left Boma, and were summarily executed. A column about 120 strong, composed of French Senegalese, with nine white men to command them, set off in pursuit. The reason for taking the French Senegalese was that the State feared to trust its own soldiers to the work, and with these natives it adopted a method that could hardly have the sanction of the civilized world, even though the operations were being conducted against savages. The commandant of the column was furnished with a bag of five-franc pieces, and an enormous quantity of wine and food. He was instructed to pay the Senegalese twenty-five francs each for every head they should bring in, the condition being that they should bring to the commandant the actual heads of the men they killed. The natives were told the terms under which they would be paid the money, and the hunt began. The column had received permission from the French governor to pass into his territory. On the 5th of May it came up with the fugitives at the Luala, on the road to Loango, in the French territory, about fifty-two miles west of Brazzaville. There the State troops fought a victorious combat, when a number of heads were taken and duly paid for. All those who did not fall at the Luala were taken or surrendered in the bush, as they had neither arms nor baggage, and were unable to proceed.

It took Boma a long time to get over the fright, and the revolution also struck terror into the hearts of the garrison at Leopoldville. There for a long time there had been two messes, the very superior officers of one class not deigning to sit down with those of a lower rank. But the shock was a great leveller; for weeks afterwards the first mess invited the second to come and dine with it, and each man used to go to mess with a loaded rifle. Yet the revolt need never have happened if the Belgians at Boma 
had shown a little more devotion to duty and a certain amount of tact in dealing with the native soldiers. But neither quality is characteristic of most of those who are out colonising on the Congo, and the officer who ought to have been on duty at the fort when these two hundred men revolted is still an officer in the Belgian army. The whole affair is a striking commentary on the Belgian system of military administration on the Congo.

From Boma to Matadi is but half-a-day's journey by steamer, which I made as soon as the festivities of the railway opening ceremony had been completed. But the entire steamship service had been disorganised for the purpose of showing-off to the delegates who had come from various parts of the world the grand fleet in possession of the State, and the consequence was that a journey which at the best of times is not very enjoyable was made distinctly unpleasant. Fortunately I had not a very long stay in Matadi, which offers practically nothing to interest the traveller, especially one who has seen it before. It amply justifies its native name of "The Place of Stones," for it is one continuous monotonous ridge of stone, sparsely covered with scrub. It was here, by the way, that Stanley received his native name, which stuck to him throughout the Congo- "The Stone Smasher," for in his day the roads were not yet made, and his march from Matadi to Leopoldville was infinitely more difficult than anything that has to be accomplished in Congo exploration to-day. He had simply to blast his way through the rocks to Vivi; and when he told the natives the direction in which he meant to proceed they were simply incredulous. When it came to blasting rocks they were struck dumb with a mixture of amazement and fear, and dubbed him reverently "The Stone Smasher." I fancy they thought he had quite supernatural powers.

The first sight you get of Matadi from the sea is a scattered picture of a few houses and two long sheds in the foreground. These last are the ivory and rubber sheds containing the valuable and doubtfully-acquired produce of the State waiting to be shipped to Antwerp. There is practically no accommodation provided for the State servants travelling up to their stations as they pass through Matadi, though the place is the head of a district and might easily and usefully provide accommodation for the numerous officers who are constantly passing through it on 
their way up and down country. I found that I was expected to make the best of so-called hotels, where everything is scratch and uncomfortable. I had-as every other officer had-to look after my own baggage; there is no such person as a porter. I had to share a room with another man, the accommodation at the hotels being so limited that there is never nearly enough room for all; and the consequence was that I was not sorry that I had to move on the next morning. It was with relief that I turned my back on Matadi early on the morning of the 3rd of July, having got my baggage on to the train and settled myself comfortably in a first-class carriage.

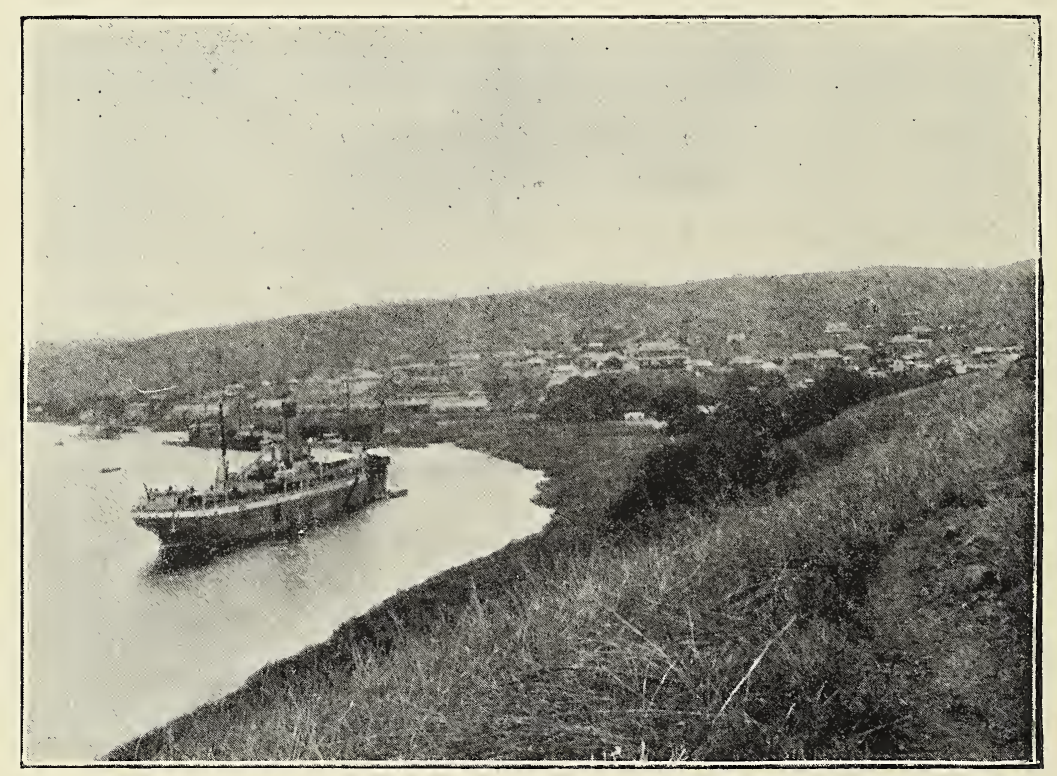

MATADI PORT.

I could not help reflecting what a difference this line had already made to this part of Africa, and contrasting the whole thing with its appearance when I went up in 1894. Then there was no railway. The route had only just been surveyed, and we were still compelled to use the native tracks and to cover the distance on foot-one or two white men and a long, lingering file of native porters. Progress was indeed slow and the march trying, and it took twenty-one days to accomplish a journey that now takes two. It was no uncommon thing for the baggage to be filched; 
for the natives to strike work; for sickness to occur on the route. Now travelling is absolutely safe, if somewhat slow; and I was glad to be spared what used to be the bitterest and most trying part of a long and toilsome journey.

But though this is an enormous improvement on the old days, the journey might be made infinitely pleasanter if the convenience of the people using the line were studied in the simplest way. For instance, the price of a ticket from Matadi to Leopoldville was five hundred francs; and, considering this is what is charged for no more than twenty-four hours' travelling, the railway company makes rather a good thing out of it. Some people even refuse to pay it. The British Consul is one of them; he always comes down

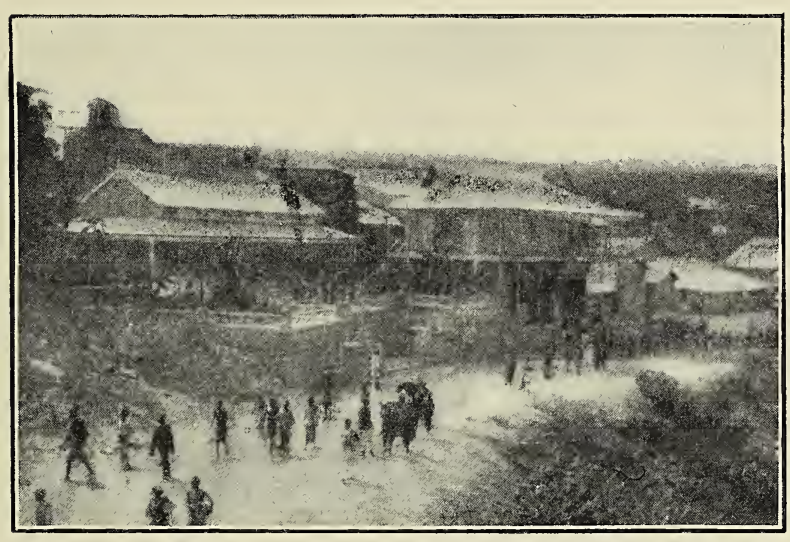

A STREET IN MATADI.

third-class by way of protest, travelling with the natives in the open trucks rather than pay what he rightly thinks to be an exorbitant charge. In addition to the high rate of travelling along this route there is another high rate to be reckoned with, and that is the excess charged on baggage. The officers of the State are under agreement to go out to their posts for three years, and of course for that period they have to take all they require when they go up. Yet the State allows them, as it allows everybody else, free transport for no more than five hundred pounds of baggage. That, of course, is quite absurd, being far less than the most careful man can possibly do with. The consequence is that a good part of a month's pay was spent in getting to my station. 
I did not find the journey to Tumba unpleasant after the troubles I had already gone through; at least I was at rest, and was not bothered with luggage and the attendant official vexations. I spent the time of the journey up in making some notes on the construction and working of the line, which convinced me that the vexatious regulations with regard to baggage were entirely unnecessary to make the line pay. I should say it ought to do so without that.

The line is single, admirably laid, and the district which it traverses gives one a good opinion of the engineers who planned and built it. I fancy, too, that Major Darwin's dictum, made in the days when the Congo railway was only existent on paper: "That there was no place in Africa where two hundred miles of railway might be expected to produce such marked results" has been amply borne out. But I shall return again to the subject of what I may call the politics of the Congo railway schemes, and will content myself for the present with a description of the line. I had already made some acquaintance with it on my journey down in 1899, the section as far as the Inkissi river being then complete. At that time it was by no means in working order, and everything was being run experimentally. The Belgians had learnt a good deal since then, and I found the line little different from the ordinary secondary railways of the Continent. Of course, a high speed is neither necessary nor advisable. There is only a single line to work with, and practically only two trains traverse it each way per diem. Owing to the nature of the country through which it runs, the line could not be a very direct one. As it carried me through a deep gorge, round the base of a mountain, over a perfectly appalling gradient, or across some deep gully by a bridge that was put up heaven only knows with what difficulty, I felt that it did credit to the men who made it. I cannot say the scenery along the line is interesting-certainly not more so than the monotonous banks of the river, of which occasional glimpses are caught as the train proceeds.

The men employed are partly natives and partly imported white men, these being of all nationalities, with a preponderance of Belgians. The native has shown that he can run an engine very intelligently, and the prediction that the negro would lose his head when entrusted with such responsible work has been amply 
refuted by himself. Senegalese and the men from Sierra Leone make the best engine-drivers, learning their trade from one another by being first apprenticed as firemen. Coming down the breakneck slope from Palabala, however, there is always a white man on the foot-plate. The railway cannot afford to run any risks, and the line at this point would give thought to a good many white men, let alone the best-tutored savage. Porters, guards, stationmasters and all wear no uniform, but they are obliged to wear clothes, as are all natives in the State employ throughout the Congo.

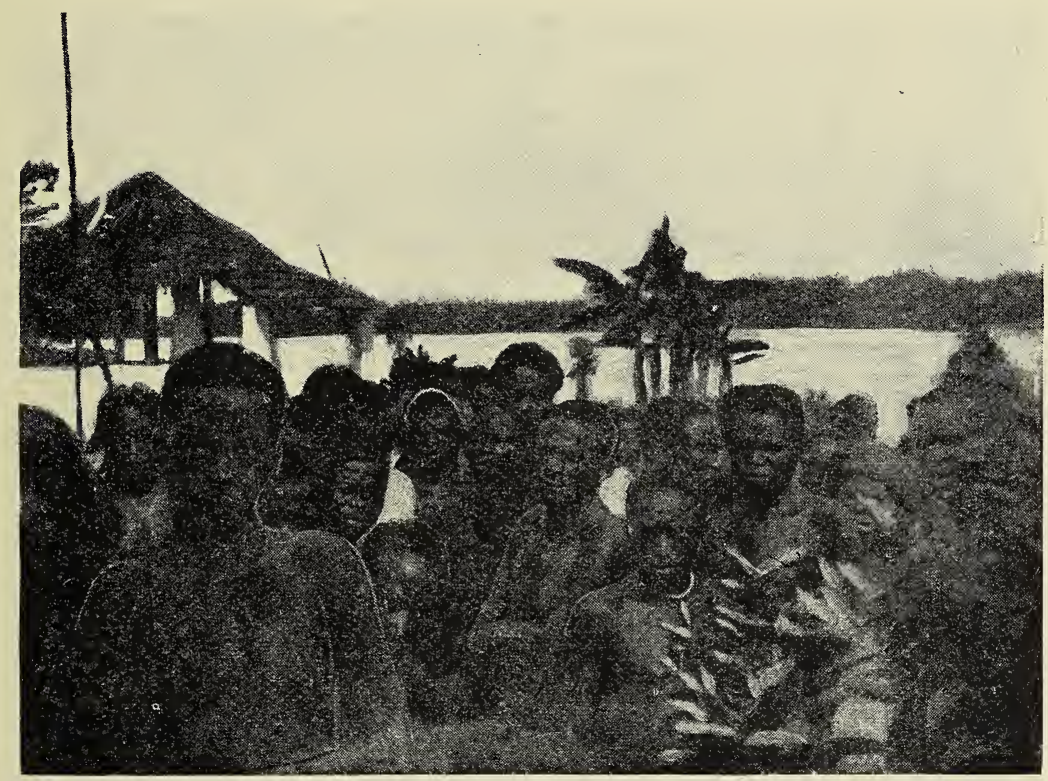

MARKET.

The first day's journey brought me to Tumba, where a halt was made for the night, as the trains on the Congo line do not proceed after nightfall. There I began to realize once more the unpleasantness of tropical travelling by a railway that is in the hands of monopolists. There was practically no better accommodation at Tumba than at Matadi, though the station is the head of the cataract district, and really an important place. I found a hotel of sorts, at which I got very poor accommodation and had to pay a, ridiculous price, out of all proportion to the allowance made me by the State for travelling purposes. For room, food and 
everything the State allows its officers journeying to their posts twenty-three francs a day. At Tumba my room alone cost ten francs and that I had to share with another man who happened to be going up by the same train.

Fortunately the stay at Tumba was very brief. A start was made again at six o'clock the next morning, and through much the same sort of scenery the next day's travelling brought me to Leopoldville, the railhead.

Leopoldville (called N'Tamo by the natives) is altogether a different place from Tumba-or in fact from any other station in the whole State. From a trading point of view it is really the most important station in the whole of the Congo; and in addition it has, of course, the railway to lend it further

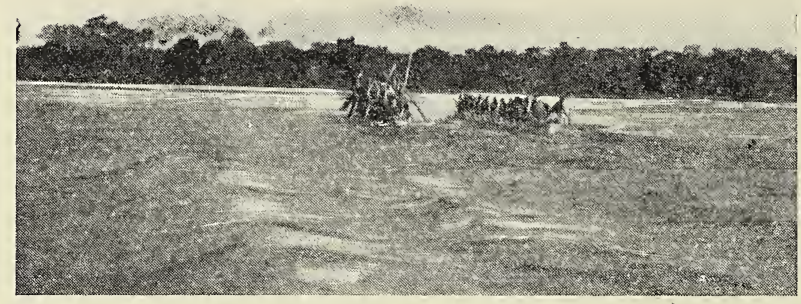

CANOES RACING.

importance; and I suppose there are more white men in Leopoldville than in any other Congo station. My early recollections of Leopoldville had undergone considerable modification as I came down on my journey home. This time I found the place practically transformed in the short space of eighteen months. Leopoldville is a station with a history. It was an important station on Stanley's march through Africa. Its position at the head of the cataracts, the changing-place for an upward journey of thousands of miles, and the point at which all merchandise had of necessity to be unshipped in the course of transit to the coast were favourable to its growth as an important station. It is now a flourishing town. The Belgian explorer and colonist, Costermans, one of the 
few Belgians with any idea of colonisation and proper organisation of a big tropical station, guided the footsteps of its early growth in the right paths, with the result that it has grown up on the most successful lines.

I spent about three weeks at Leopoldville, owing to the fact that there was at this point no steamer to take me up to my station at Basoko; and during my stay here I had an excellent

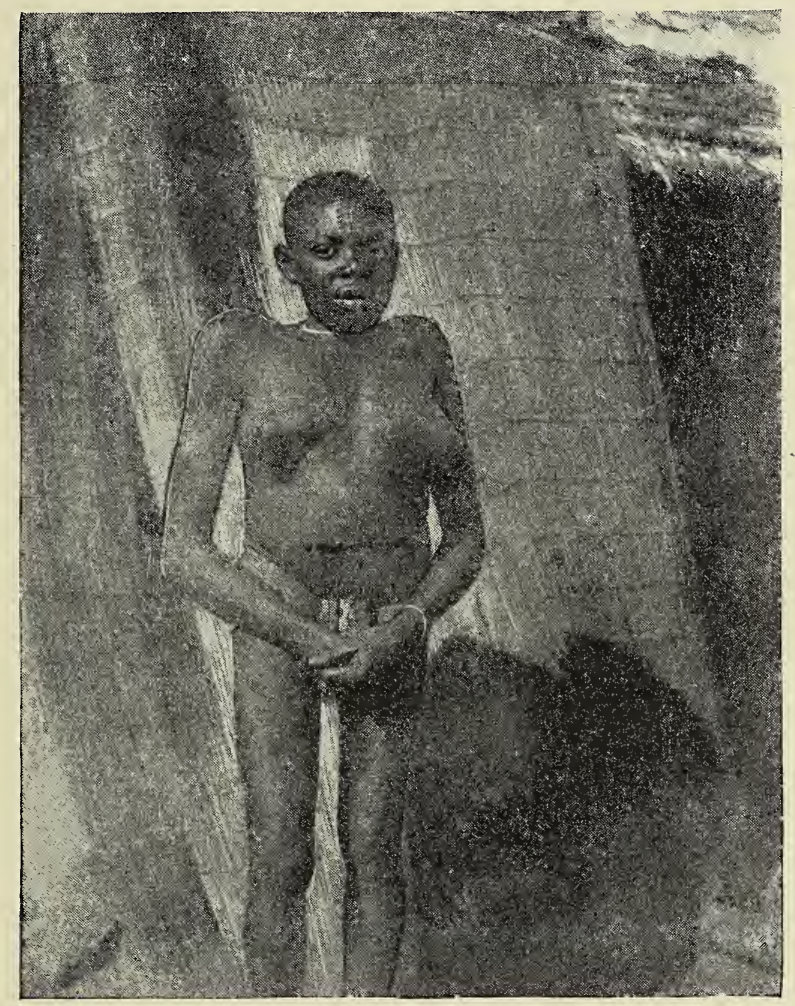

DEFORMED NATIVE WOMAN.

opportunity of seeing the station at work and play, and of watching the whites and the natives in their various relations to one another.

There are two classes of white men at Leopoldville-the only station besides Boma that boasts of such social distinctions. Ordinarily the white men at a station are so few that they are glad enough of one another's company, whatever distinctions of 
rank might have separated them at home. At Leopoldville they run two messes, or rather they did until they got that big fright after the bombardment of Boma. The first mess is that of the officers of the State, the heads of the trading companies, the chief engineers, and so on; the second is that of the engineers and fitters of the railway, the mechanics who work in the shops, some white soldiers without commissions who are employed in training soldiers and organising the military service, and others of similar position or rank.

Opposite to Leopoldville is the French station of Brazzaville, capital of the French Congo. It is a flourishing post, its success being partly due to the fact that it gives greater facilities to traders than do the Belgians on the Free State side. A particular instance came under my notice as I passed through. The Dutch trading company, which goes by the name of the Nieure Afrikaansche Handels Vernootschaap, wanted a piece of land for the use of its director. The Belgians offered him a small plot big enough for a house of sorts and a back yard. He made application to the French, and was accorded forty-five acres. Needless to say, the Dutch trading society removed its headquarters to the French side, and the Belgians lost another source of revenue.

The circumstance is quite common higher up the river, and extends to the natives even. They go across to the French side in large numbers, for there they are not worried out of their lives for rubber and ivory.

The Free State has several little ways of making itself unpleasant to its employés by imposing on them regulations which are merely humiliating and designed to restrict their freedom in an unnecessary direction. One is the interdiction of absinthe. I hope I shall not be misunderstood when I say that I regard a certain amount of spirit as necessary to a man in the tropics as on the Congo. Hematuric fever is rife, and I have found that the men who never drank anything and who were non-smokers generally came off worst when there was fever about. I had previously made the same observation in India, and my Congo experiences go to prove it. The State allows each officer to buy three litres of alcoholic liquor per month. The effects of the rule are hardly what they are intended to be. In the first place, the rule itself practically invites the evasion of it. 
Such vexatious and mistrusting regulations generally have the opposite result from that which their framers intend. The usual consequence is that the youngster who comes out to the Congo supplements his good three litres with several litres of a less wholesome kind-native gin, as often as not, and rank at that. So that good spirit, which would have done him practically no harm, is denied him, and in revenge he takes unwholesome stuff, probably finding the allowance of three litres quite inadequate. The French on the opposite bank know no such restrictions; yet they are not suffering in any marked degree from alcoholism as far as I am aware.

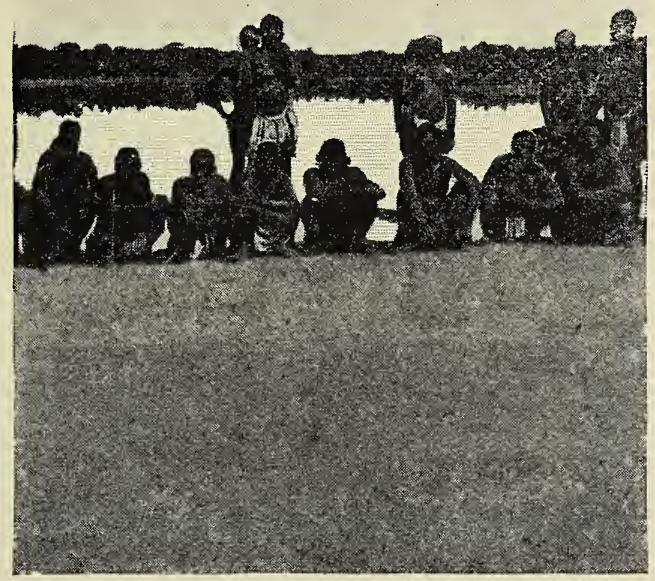




\section{CHAPTER II.}

A Long Stay at Leopoldville-A Desire to see Kinchassa-Recruits at WorkShooting-Practice-How They are Recruited-Views on Soldiering-Zandé Defiance-The Batatela-Mobangi-A Tale of Belgian Treachery-RetributionAn Alleged Voluntary System-Terms of Service-The Camps of Instruction-A Want of Forethought-Few complete their Term-Wood-Posts-The White Man's Word-A Drain on the Country-The Volunteers-A Different Footing.

I was kept at Leopoldville considerably longer than I had intended, owing to the circumstance that there was no steamer to take me on to Basoko. During the time I was there I had little to occupy myself with beyond going thoroughly over the post and watching the work of the station; and when I had seen all there was to see in this place, and had made a mental resolve that if ever I became chief of that station it would see a good deal of alteration, I went across to Kinchassa, a station I had passed in the train but had not stopped at long enough to allow of my getting out and prowling round. I specially wanted to see Kinchassa, because it is one of their model camps of instruction for the natives who are enrolled in the Force Publique. I was anxious to see their system at work, and to compare it with the one I had seen during my first term of service on the Upper Welle.

I went over to Kinchassa by train from Leopoldville. The station is right on the Pool, close to a point which juts out into the torrent about one mile down stream. This point is called Kallina, after an officer of that name who used to be in the State service. Kallina was an Austrian, and he used to go about in full kit-top boots, ammunition belt, big coat, a rifle slung across him, cavalry sword, revolver, and so on. One day he started up river in a canoe to round the point. In his canoe he had placed a big box containing his effects, on which he sat, bolt upright. His crew were 
not very good watermen, and in any case totally ignorant of the navigation of the Pool. Of course, his boat was topheavy; like all native canoes she was merely a dug-out and quite innocent of keel, so that the slightest movement made her roll. As he neared the point the current caught his boat with such force that the rowers completely lost any control they had had over her, and in a few seconds she capsized. The paddlers, being unencumbered with heavy clothing, managed to scramble out, but Kallina, weighted down with his heavy armour, sank and was drowned, and of course his body was never recovered.

Kinchassa is a lovely place, surrounded by plantations and running right down to the beach of the Pool. Its houses are well

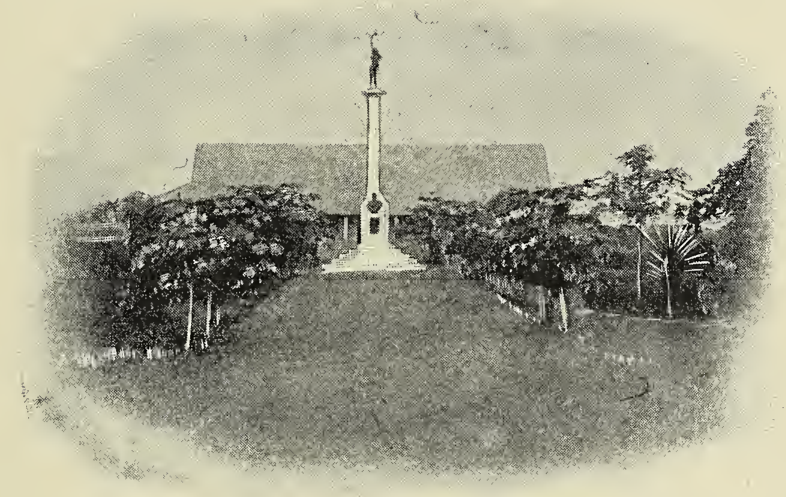

STATUE OF LIBERTY, LEOPOLDVILLE.

built, and some of the gardens belonging to the officials of the station are beautifully kept. From the verandahs of those houses one could get a grand view of the Pool, looking clear across to the white cliffs on the other side-called by Stanley "Dover Cliffs"and to the French station of Brazzaville. At the back of the town is the camp, which I was anxious to visit, and near to it is the native village, which, by example of the neatness of the camp, is kept in better order than most of the native villages.

When I arrived the recruits were just being taught the principles of firing exercise. They were mostly men enrolled from the far eastern province of Stanley Falls. A target had been set up against a tree trunk, and the natives, having learnt some- 
thing of the mechanism of the Albini rifle-a pattern which was formerly in use in the Belgian army, but which had been discarded and the disused rifles sent to the Congo-were firing their first shots. Considering all things, they were doing very well. The distance was not great-about a hundred metres, and the mark fairly large-but they managed very well for beginners. Most of them had, of course, handled a gun before. Since the trade gun became an article of barter the natives of all parts of the State have become fairly well acquainted with firearms; so that, when they begin to use the rifle, they have not to overcome any sensations of fear with regard to the noise. In

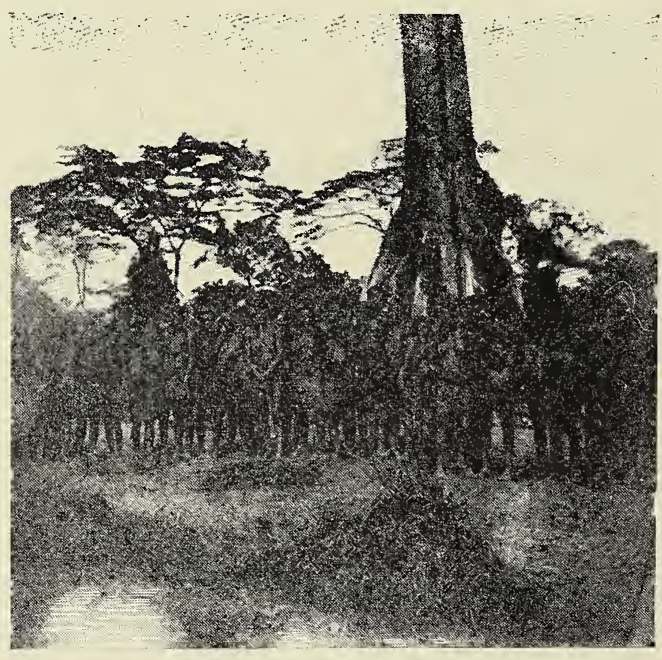

WORKWOMEN, STANLEY FALLS.

the case of the Albini, however, the weapon has a most unpleasant kick, and most of those who were firing their first shots took very unkindly to the recoil. The officer who was teaching them had great difficulty in making them understand the necessity for pressing the butt hard against the shoulder.

I found the soldiers fairly well housed and fed at Kinchassa, and consequently well contented with their lot. It pays the State to treat its soldiers well, for reasons about which I shall have something to say later on.

Every year the number of recruits is fixed by the King of the Belgians, acting as Sovereign of the Congo Free State. 
His decision is subject to the information received from the Governor-General, who receives reports from his subordinates and determines the number of men to be furnished by ẹach district. For recruiting purposes the country is divided into districts, and each chief in every district is called upon to furnish a quota of men in proportion to the number of men in his village or his tribe.

The men, having been selected by the chief, are sent to the commissioner of the district, who summons a board for the proper examination of recruits. This usually consists of himself, the medical officer, the transport officer of the district, and sometimes another officer as secretary. This board usually meets at the

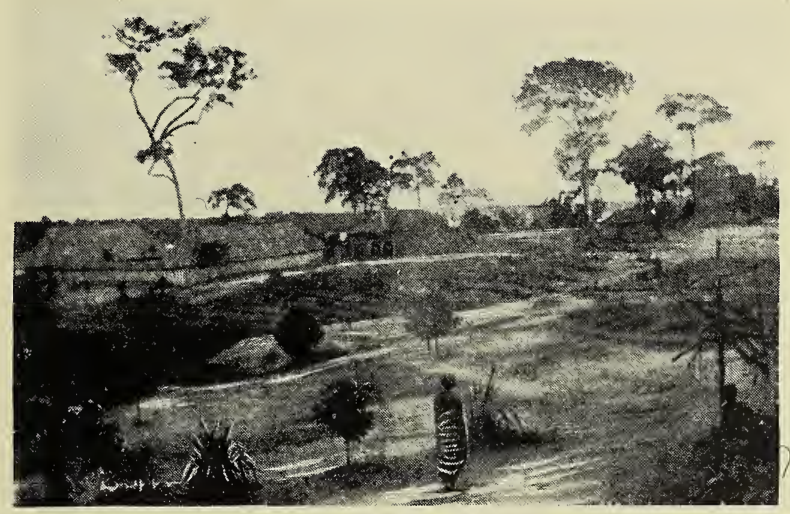

STANLEY FALLS STATION.

(Showing how all the Plantations had been cut down and replaced with barbed wire in expectation of an attack by revolted soldiers.)

headquarters of the district, and generally transacts its business on the verandah of the commissioner's house. Sometimes the examination of recruits is productive of some humorous incidents. For instance, on one occasion when I was examining men for service an old man about seventy presented himself for enrolment. He was much disgusted when we rejected him, and put on a face as though he wondered what the service was coming to. Another turned up with only one hand. He had probably lost the other as a punishment in the days of his youth, but he certainly thought it would be no bar to his acceptance for military service. Like a good many others who 
came for enrolment, he imagined that service with the Force Publique consisted merely of wearing the State uniform and carrying a gun, both of which privileges he regarded as a valuable asset, as being a means whereby he could prey upon his fellow native. In his case he never had the opportunity of learning the fallacy of his views on soldiering.

The best material for the army of the Congo would be the Zandé, the powerful tribe of Niam-niam, which is spread across the district of the Upper Welle. But they are unobtainable. They simply will not enlist, being far too independent to serve under anybody but their own chiefs; and their own chiefs are not sufficiently under the thumb of the State to submit to coercion. This tribe, in fact, is so powerful that the State cannot afford to

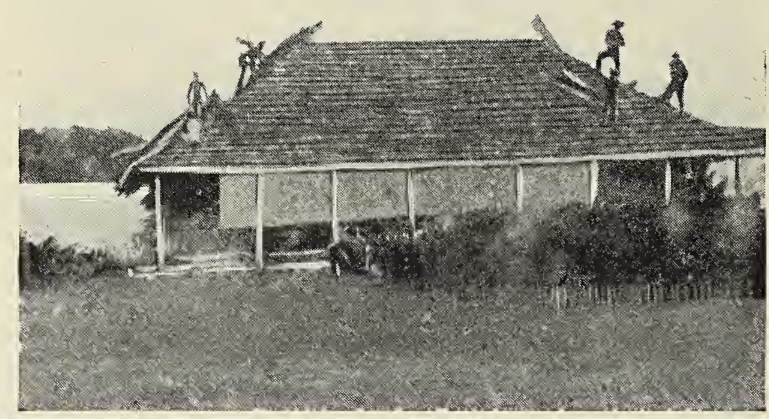

TIPPOO TIB'S OLD HOUSE AT STANLEY FALLS.

quarrel with its chiefs, and the result is that the Zande are quite exempt from military service. They are really a state within the State, and it is fortunate that they are of a much higher order of intelligence than the tribes surrounding them, and thus are a very orderly people. If it were not for this fact, and the fact that the State has found it good policy to let them alone, there would be an end to Belgian government in their part of the world. The tribe of the Batatelas is also good material, but it has ceased to be available-the State dare not enrol them now. A few are still in the Congo army, but the authorities have taken good care to send them down to the west, well away from the scene of the constant fighting between the Belgians and the revolted Batatela. 
The Manyema tribe, who come from the most easterly part of the State, near the lakes Albert and Tanganyka, make good soldiers, provided the State keeps to the letter and spirit of its contract with them; when it fails to do this they have not the slightest hesitation in revolting, as witness the mutiny at the Shinkakassa Fort, and the bombardment of Boma, which I have already related. The Bakussu, who also come from the east, are a tribe which the Belgians tap for recruits with considerable success, and the Mobangi, a tribe which was under my control when I held the post of Captain-Commandant in the Upper Welle, also make good soldiers. These last enlisted for a peculiar purpose. They were once an independent tribe, but had long been under the sway of the Zandé, to whom they paid tribute and gave other marks of

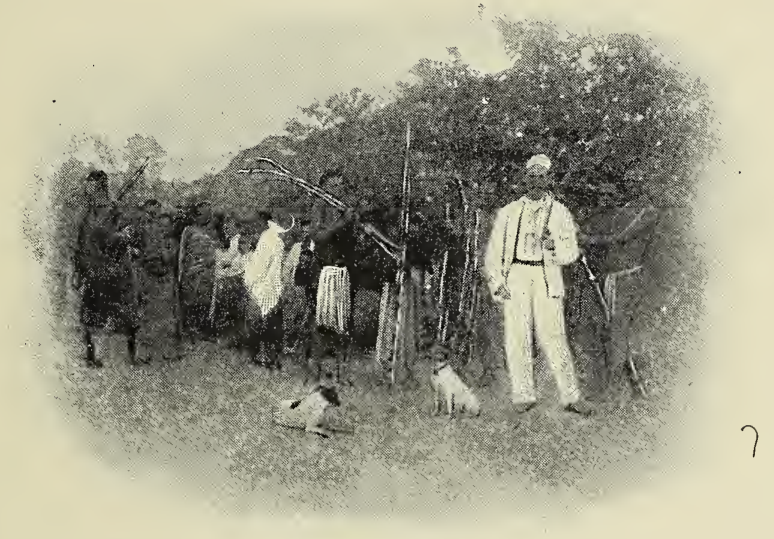

MARKET, STANLEY FALLS.

deference. It is in the hope that one day they may win back their independence and shake off the toils of the powerful Zandé that they send as many of their young men as they can spare to train in the army of the State. It is rather a fine national ideal, but I fancy that, before they are able to accomplish it, the march of civilization will have put the matter beyond possibility, and both they and the Zandé will know no allegiance but to the white man.

The Batatela are a great loss to the Belgians. They had learnt something of European methods up in the east, having been carefully trained by the Belgians. The story of the Congo Arabs is well known to most students of recent African history. My friend, Mr. S. L. Hinde, who was formerly in the 
service of the State as medical officer to the Belgians in that part of the country, set down a faithful and most picturesque story of their defeat in his book "The Fall of the Congo Arabs." It was in connection with this suppression of slave raiding from the east that the Belgians lost the adherence of the Batatela tribe, which at one period was one of their most faithful black allies. The cruel and thoughtless policy of their administrators brought its own reward. After the Arabs had been overthrown by the combined efforts of the State troops and the Batatela tribe, a stupid and brutal Belgian officer went out of his way to hang

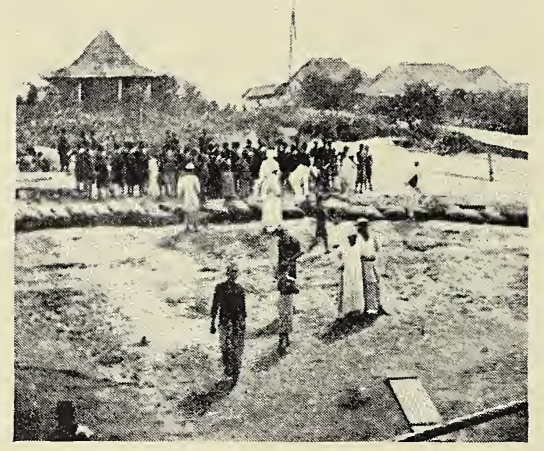

STANLEY FALLS, I895.

Luteté, the chief of the Batatelas, for no reason but wantonness or fear. Luteté had been of immense service to Baron Dhanis against the Arabs. He supplied the Belgian commander with thousands of warriors, and without him the Arabs would never have been suppressed-they would have been running their slaveraiding caravans to-day. The Batatelas never forgave this piece of treachery; they revolted against the State, cost it an enormous amount in money and lives, and the Belgians lost, in addition, the allegiance of a tribe whose gratitude would have been a great factor in preserving order in their remote country. Now we hear 
from time to time that the Batatelas have been finally suppressed; that they have been annihilated, routed, dispersed, and all the other things that happen to a stubborn foe without making any difference; and still the Batatelas are a thorn in the side of the State administration. In this case, as in many others, the barbarities of the Belgians have returned many-fold upon their own heads.

Some of the French Senegalese make good recruits, but the State will not employ many of them. They want better terms and better pay than the Congo Government is inclined to give the people drawn from its own territories. It was the same with the Haussas, most of whom came from the British West Coast colonies. In the old days the Belgians used to draw on the

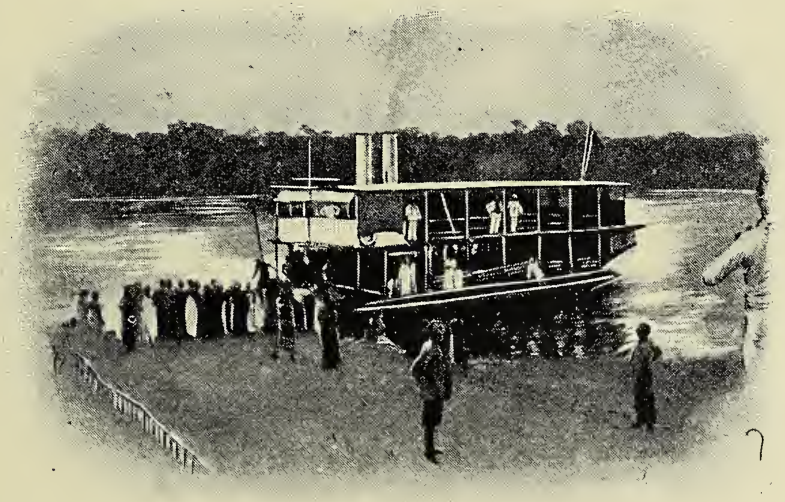

STERN-WHEELER " LE STANLEY."

British colonies pretty heavily. The men were recruited on a labour agreement with nothing about soldiering in it, and a lot of soft promises that were never meant to be kept: But the simple African has a very keen sense of justice, which can only be likened to that of a big child. Under false promises he was a good deal more trouble than he was worth; and, moreover, the British Government, when it discovered what was going on, quickly put a stop to this form of recruiting. In its plight for good soldiers the State tried Somalis. The same fine blandishments were used, and the Somalis left their eastern coast with the idea that they were going to get good pay, meat rations, and cigarettes. But 
when it came to living on the fare the State provides for its men, they died like sheep. Then an attempt was made to enrol Zanzibaris, and they stood it pretty well. But they were worthless as soldiers; for some reason I was unable to fathom they could never shoot straight. All they could do was to swagger about in their uniforms and intimidate the peaceful inhabitants of the villages in which they happened to be stationed.

There is always some trouble experienced by the commissioner of the district in getting his men together. The chief is allowed a certain bounty-about fifty francs a head-for each soldier he sends to the State service from his district, but he never gets it. More often than not his bounty, by the time it reaches him, has dwindled to a piece of cloth of varying length, quality and brightness, and perhaps an additional present for himself to say nothing more about it. Recruiting is quite nominally on the voluntary basis-that is to say, there is no law which provides for any form of conscription or compulsory service. But, as a matter of fact, there is nothing at all of a voluntary nature about this form of service. The chief who fails to send the number of men required of him soon gets into trouble, and consequently he does not refuse, because he dare not.

He certainly would refuse if he dare, and those tribes which are strong enough to refuse do so. It is an enormous drain on their resources, for they know well that most of the young men who go to the State army never return. Eight hundred, the cream of the youth, used to disappear from my district every year; and, when it is remembered that the State makes extraordinary demands on the chiefs in the matter of rubber and ivory-in which occupation many men are also carried off every year-it will be understood that the progress of the tribe is in this way very much hampered.

At the time of their engagement the men are told what is to be the term of their service, and what are the conditions of their contract with the Government; and since the affair at Shinkakassa, when the deluded Manyema natives bombarded Boma, the Government has been a little more careful in keeping its word with the natives. 
The soldiers thus enlisted are the regulars of the Force Publique. Their term of service is seven years, at the end of which the Government undertakes to repatriate them. Each man is given a book, into which is written all his payments and advances. Pay, of course, is mostly made in kind; money would be of no use to the black soldier in an out-of-the-way station. Mostly he elects to receive his pay in cloth from the store. The natives used to be paid in money; but that led to very great abuses on the part of the white men. The soldier was paid with a number of coins that to him had no meaning, or value among his own kind; and when he sought to get it exchanged for cloth he was quite ignorant of the amount he ought to receive. Certain officers were not above taking advantage of his simplicity, giving him short measure in cloth and pocketing the change.

These men are called "miliciens," as distinct from the force of volunteers, whose terms of service I shall describe later. They receive twenty-one centimes a day, but they cannot touch the whole of it as they earn it. A certain amount is kept in reserve until they have completed their seven years, which for various reasons very few of them ever do. They receive also their rations.

When the new recruits have been enrolled they are drafted off to camps of instruction, such as the one at Kinchassa, which I visited during my stay in Leopoldville. Generally care is taken that the soldier shall be sent to a camp as far as possible from his native village, as it has been found that the black does not understand the proper spirit of soldiering when left in the neighbourhood of his own people. He is apt to look upon his uniform and rifle as methods put into his hands by a merciful Providence in order that he may tyrannize over his unfortunate relatives; and these, not realizing the humble position he occupies, and seeing only the wide gulf which separates them from a "State official," seem to be quite willing that he should exercise his mistaken authority. So the State moves him off to east from west, and from south to north. This plan has a good many other advantages from the State point of view; it would never do, for instance, to have the soldier alternately appealing to his own chief against the State, and to the State against his own chief. At the same time some care has to be exercised in choosing the districts into which the men are sent. In this respect the State has made some 
costly experiments, which might have been avoided by a little forethought. For instance, a number of men from the Welle district were moved down to a camp of instruction on the equator-Irebu. But the diet was quite unsuitable; the men of the Welle were accustomed to the banana as their staple food, and when they were thrown upon cassava they simply died like flies. Some of them took time by the forelock and deserted to the French shore; but as a rule there is very little desertion, and most of the natives are good men at dying.

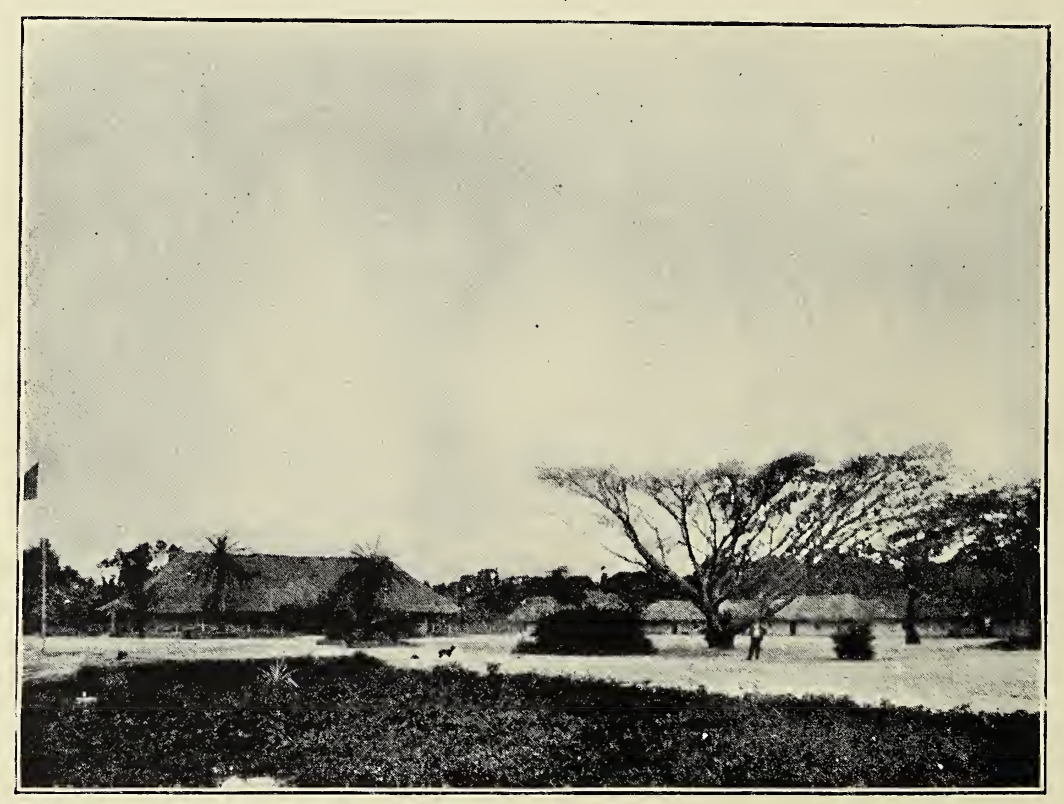

BU.MBA.

Besides, desertion offers few attractions. These men are all away from their homes, and the bush is no place for a stranger in tropical Africa. It would merely mean that sooner or later they would be killed by some village, and a grand feast would follow.

When they are well treated there is little fear of their deserting. It is only when life is intolerable that they take a course which means certain death-and this, I am glad to say, happens less often now than it did a few years ago. But in any case few of 


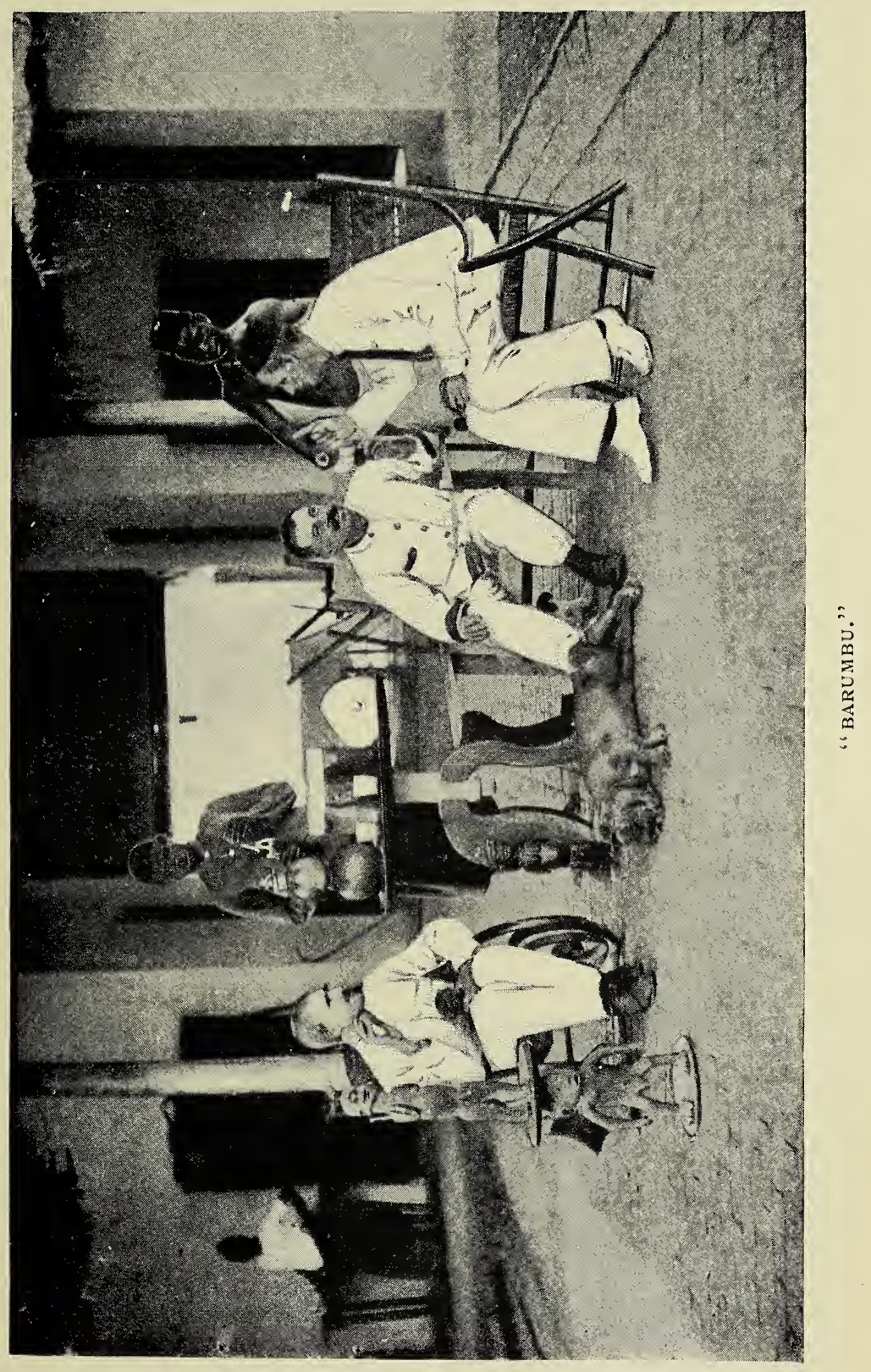


these men ever serve their seven years. The drain of the punitive expeditions; the punishment wars on chiefs who have been unable to satisfy the rapacity of the State for rubber and ivory-these are one certain drain. For another thing, the soldiers are called upon to do a lot of work in isolated places, such as the superintending of wood posts, and the keeping in order of roadway posts; and when they are alone in out-of-the-way places the local tribes consider them fair game. Either the soldier gets at loggerheads with the chief, who has him killed for the sake of convenience, or the people anticipate the trouble by killing the soldier who might cause it. Then, of course, there follows another punitive expedition, and more people get killed, and, as in most Congo squabbles, the last state of things is considerably worse than the first.

This wood-collecting work is one of the principal necessities on the Congo river. There being no coal in the country-for Lieutenant Lemaire's boasted scientific expedition, which bragged so much about the coal it found, in reality never found any at allthe river steamers are obliged to burn wood fuel. This is collected from the various villages in the neighbourhood of the stations, the chief being obliged to furnish a certain quantity under pain of being shot at or imprisoned. To keep him up to the mark, a soldier, or perhaps two or three, is located in the village, and generally succeeds in overawing and bullying the chief until the aforementioned retribution overtakes him. Some of the chiefs supply their wood with great regularity, and a soldier quartered upon them to bully them and abuse their women is really nothing short of an outrage. A certain chief of a village near my station at Basoko had had an experience of this kind, and came to me one day with the request that I would recall the soldier, at the same time undertaking to supply his quantity of wood with no less regularity and a good deal more comfort to himself and his tribe. So I withdrew the soldier and never had any trouble with this particular chief, whose wood was brought to the post with great promptness, and always up to the required quantity. This sort of thing happens rarely, the chiefs being very disinclined to have any but enforced communication with the white men. They have had such bad experiences with the colonising Belgians all over the country that they often refuse now to take a white man's word-and I do not wonder. But to an officer who has served in 
India, where the white man's word is believed in implicitly by the natives, I found the Congo conditions in this respect very trying. It cost me considerable trouble to win the confidence of the natives in my own stations; they had been so maltreated, and had been subjected to such falseness by my predecessors, that they had come to look upon all white men as liars and crueltymongersand if you are not that way disposed it is somewhat galling to have to live down a bad reputation left you by your predecessors, and almost certain to be revived by those who follow you.

It is a great nuisance having to use soldiers for this work, but I am afraid, in the present condition of the State, it is impossible to help it. Of course, the proper way would have been to gain the confidence of the chiefs, instead of alienating them by injustice and worse. In that case it would have been possible to work and exploit the villages to much better advantage, and it could have been done if the initial stages of Congo colonisation had been carried on with even a minimum of foresight and common sense. But that is going back to the regrettable unalterable in history, for I fancy it is too late to amend matters to this degree-certainly under the Belgian system and régime. As it is the soldiers have to be sent to these outlying posts, in which it would be impossible -and in any case not worth while-to locate a white man. The soldier promptly imposes on the chief. He takes unto himself a wife at the chief's expense, and as a rule the chief consents in order to curry favour with the soldier, who has as much power-and uses it as indiscriminately-as an Irish constable at a League meeting. Do what you will you cannot stop this condition of things, and the result is that numbers of chiefs lead lives of wretchedness simply owing to a faulty condition of government.

In the principal stations the soldiers are quartered very decently. Their huts are built in lines, sometimes of brick, sometimes of wattle and plaster. The state of them depends a good deal on the station, and the energy of the officer at the head of it. I built them brick houses at Basoko-the unmarried men living four in a good-sized room, and the married ones having one good room and a verandah each. The unmarried men live generally in the regimental system of the Belgian army (on which their discipline is modelled), with the exception that they cook their own food. The married soldiers have separate quarters, and each married couple 
has one room. They are generally single until they reach the rank of non-commissioned officer. Of course, all the officers are whites-except Djabbir, the old chief in the Upper Welle district, who is an honorary commandant in the service and allowed to wear its uniform. The army is not very big. It is really not as big as is necessary with the everlasting punitive expeditions that are going on ; but I fancy it is as big as the country will stand at present.

The country is politically divided into fourteen districts and zones. Each has a company, whose full strength is according to

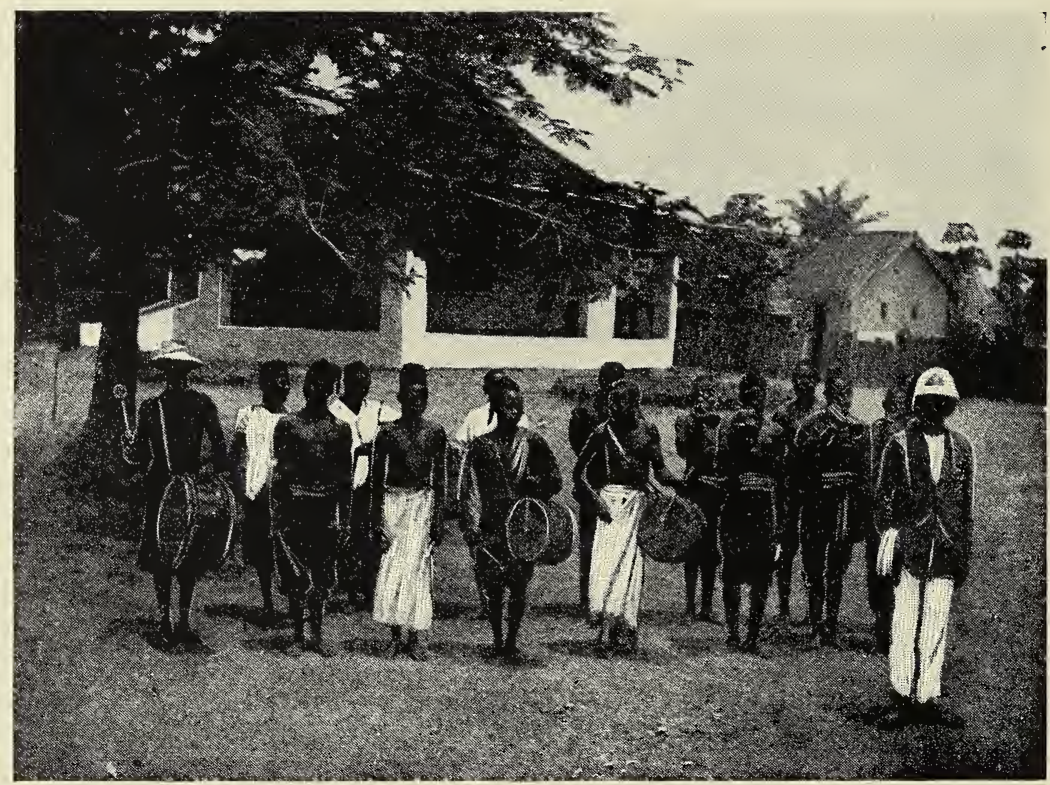

A NATIVE BAND.

requirements. There is no uniform distinction or badge, and no kind of rivalry between the companies. The negro in Central Africa, as elsewhere, makes a pretty good bandsman, and some of the regimental music is of very fair quality, though with a tendency to be mechanical. There are also some good shots, and this form of diversion they take to more kindly than blowing trumpets and beating drums, which they would enjoy more if the band were a go-as-you-please affair; but they look on both occupations as part of the day's work, and have no desire to do them better than they are made to. 


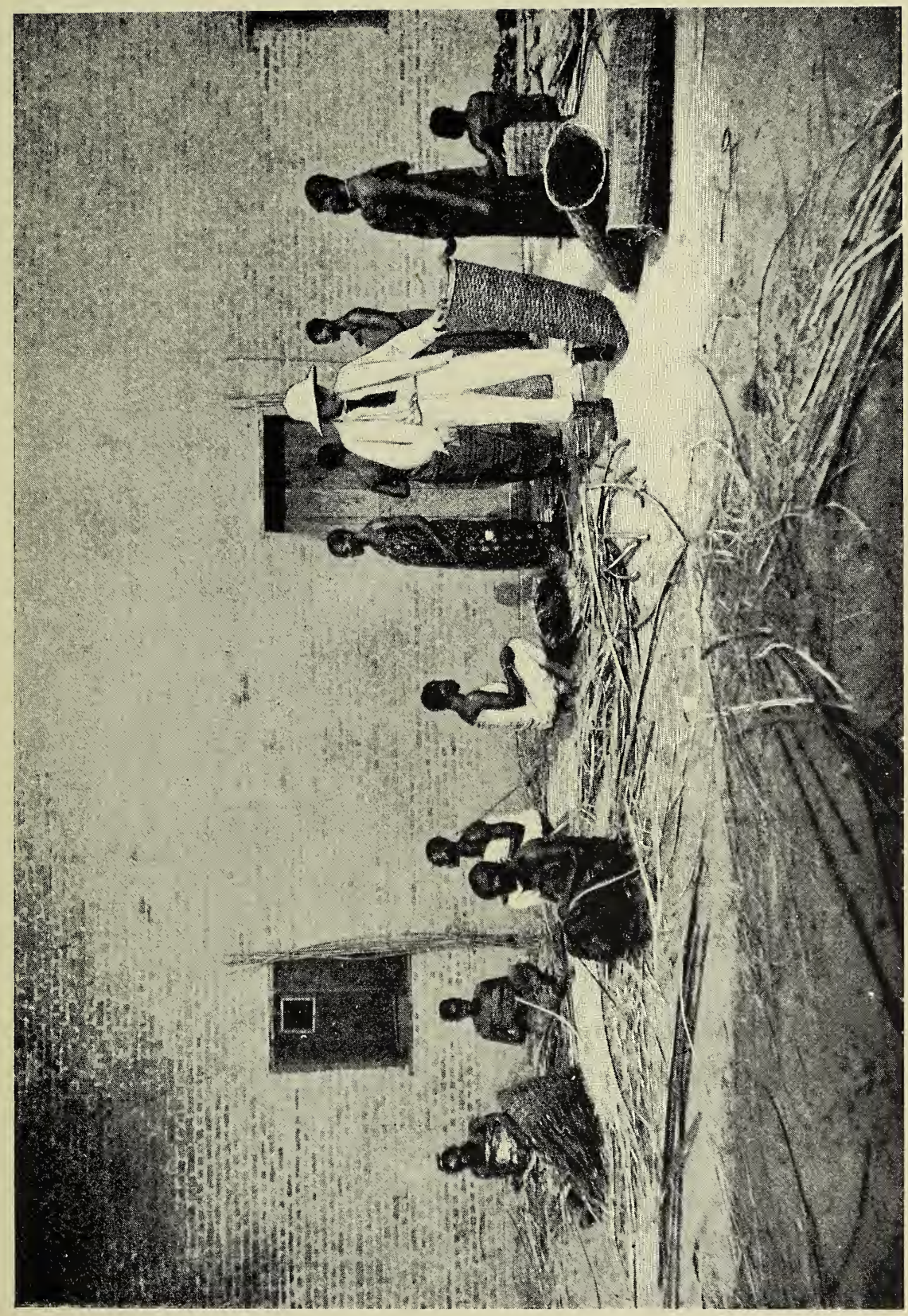

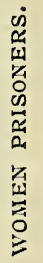


There is, besides the regular army, or Force Publique, a class of volunteers who enlist and serve under quite different conditions, and are really a fatigue corps of workmen. They are taken on (after the same medical examination) for a period of under four years. They are, however, not sent to camps of instruction, but are trained in the districts where they are raised, and counted as permanently attached to these districts. Consequently the State never has any difficulty in getting these men, who swagger about among their own people directly they are taken on, and, barring a tendency to use the State power for private ends, police the country excellently. They are paid five francs' equivalent a month, and, of course, they receive free rations; and it is a consideration they value that, while their less fortunate brothers are harried out of their lives for rubber and ivory, these men are frequently told off to do the harrying. And that means perquisites.

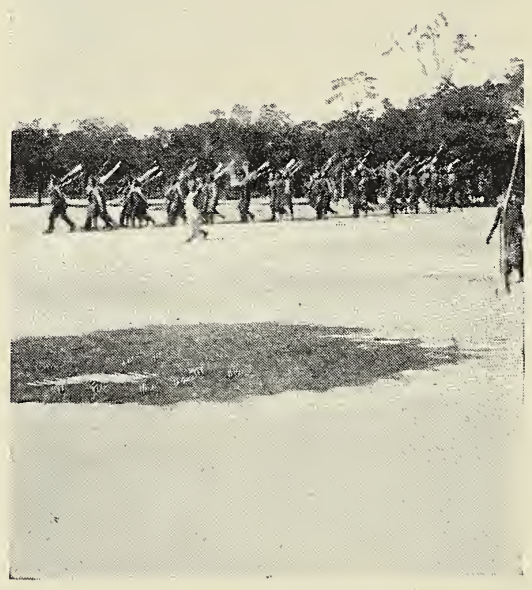




\section{CHAPTER III.}

Bolobo-Grenfell's Station-Missionary Difficulties-Life's Failures-The Wrong Men for the Work-State Methods-The Native Protection Commission-The Bishop's Prohibition-Sacredness of Rubber and Ivory-Equateur-Workpeople and Recruiting-Punitive and Labour Expeditions--Terms of Service Unsatisfactory-Practically Slaves-A Slave's Return Home.

Leaving Leopoldville on the 2nd of August I was soon clear of civilization. I travelled in a very comfortable vessel, the "Brabant," 150 tons, a steamer of a new type, and much larger than the vessels then in use on the Congo. It was her maiden trip, and she made a very good passage; but at that time the authorities were a bit afraid of her, not knowing how far it was safe to proceed with vessels of her draught-about five feet-so I did not get right up to Basoko in her. But later on they found that the river was deep enough right up to Stanley Falls, which station she now visits regularly.

One of my early stopping-stations was Bolobo, the village at which Mr. Grenfell, the English missionary, has established his settlement. The work of this pioneer in the heart of Africa is too well known to need words from me. I saw his station, and, knowing the country, I was able to appreciate, perhaps better than some of the people at home, the extent of his work and the terrific difficulties he must have been confronted with and have conquered during the early stages of his work. At present his missionary colony is a model of what a missionary colony can be; and it is only when one knows African conditions that this qualification of mine can be understood. The very size of Africa is the greatest obstacle missionary work has to overcome. Each station, be it ever so successful, is but an oasis in an enormous desert; a small green patch amid a howling wilderness. And not always is it a 
green patch, for there are missionaries and misssionaries. I am not inclined to go in for the wholesale condemnation of the missionary that is often found in books of travel. Those I have come across have varied, as men have varied in all the walks of life I have met them in, on the Congo. Some were excellent fellows; some were well-intentioned but deficient in judgment; and a good many were weak-chinned, and the wrong men for the work: a few were rank. The tropics do not improve a man's character, and on the Congo, amid the foetid atmosphere of State cruelty and State repression, it would be surprising if

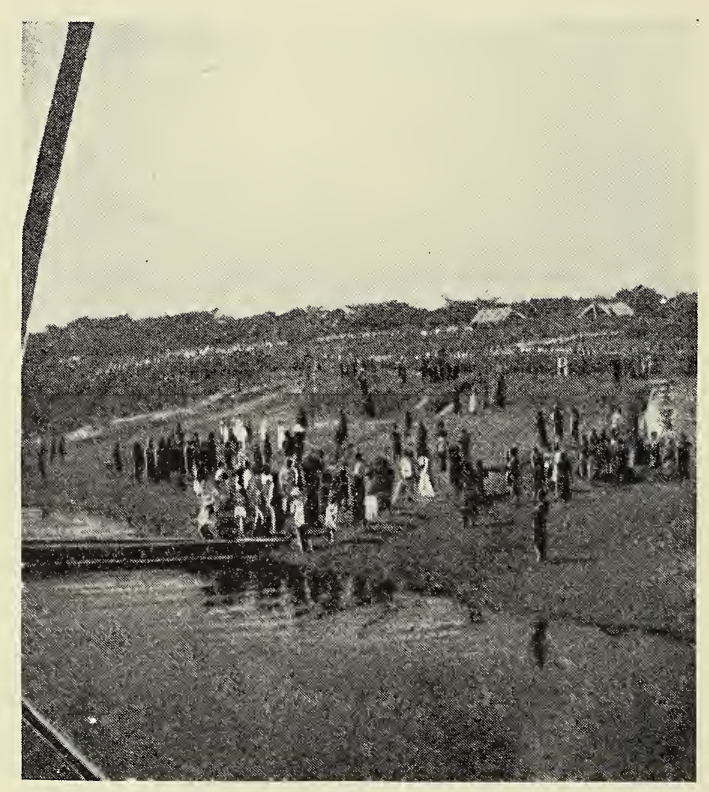

BOLOBO MISSION STATION.

the proportion of unpleasant people were not larger than in countries favoured by a better rule. If a $\mathrm{man}$ is inclined to degeneration and brutality, the Congo Free State is a good forcing-house for his evil qualities. Too many of the missionaries, to my mind, are recruited from young men whose past vocations have been the humbler, useful stations of life, such as countermen or clerks, and who have what is technically termed, I believe, "obeyed a call." The "call," I am inclined to think, had a good deal to do with a desire to escape unpleasant consequences 
resulting from some form of indiscretion or other, or perhaps merely from a craving for other surroundings. They would have done better as hands on a cattle-boat-it would have made men of them. As it is they are merely missionaries, and, in consequence, bad missionaries.

I should not care to have their work in the Congo Free State. They are fairly in the toils of a most immoral corporation, and they are obliged to frame their actions according to its dictates. They have no option in this matter. If they became in the least degree troublesome; if they denounced a single one of the crying evils that surround their daily lives; if they taught the native the iniquity of the conditions under which he is made to live and groan, they would soon cease to be missionaries in

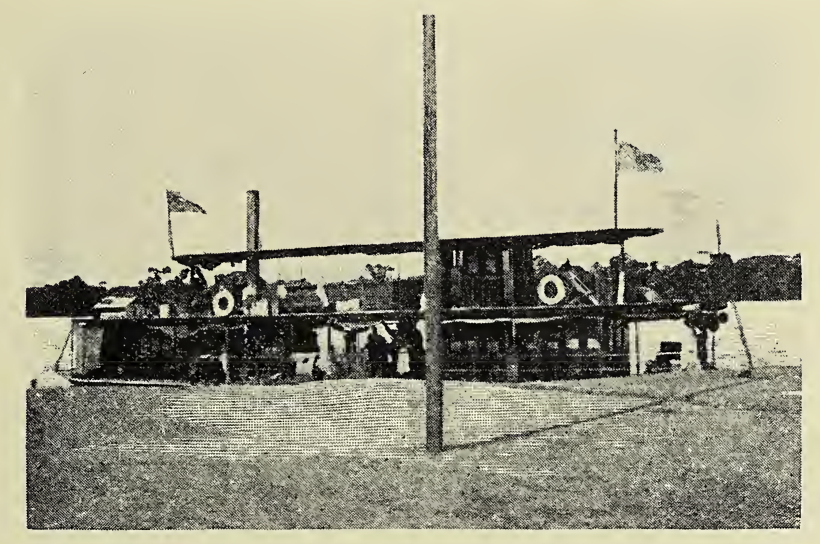

BAPTIST MISSION STEAMER "GOOD WILL."

the Congo State. The Government would soon make their lives a burden to them, a task by no means difficult in a country where everything is a monopoly; and it would by this means harry them out of the country. Most of them are dependent upon their mission work for their daily bread; they have no choice but to endure and close their eyes to their surroundings.

Mr. Grenfell is a member of the Commission for the Protection of the Natives. I fancy the Commission is well-intentioned, but of little practical value. Dr. Sims, the medical officer to the Leopoldville Mission, who was of the Commission, described to me its first meeting. It was impressed upon the commissioners by the Roman Catholic Bishop of the Congo, the President, who was 
present to voice the Government's sentiments, that on no account were two questions to be touched upon in the dealings of the Commission. The one was the question of the methods employed by the State and the private companies in the collection of rubber and ivory; the other was the action of these worthies in relation to obtaining recruits. These being practically the two matters in which the lot of the natives needed improving, the

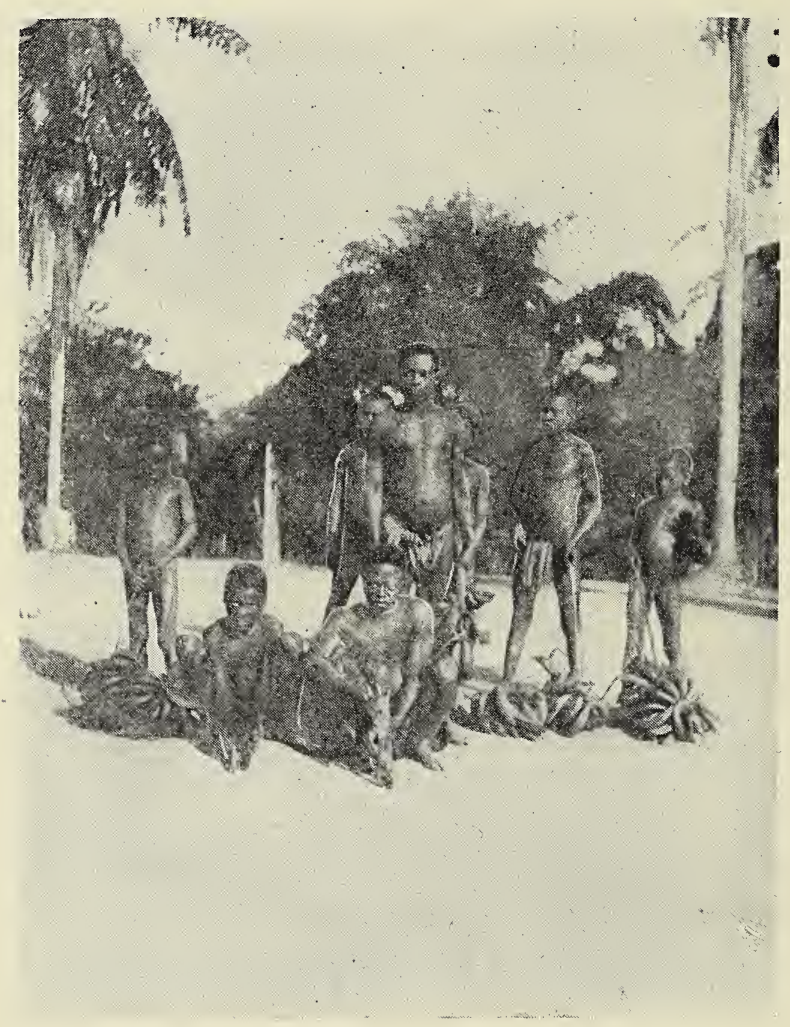

NATIVES BRINGING IN FOOD.

Commission was at one stroke deprived of any value it might have possessed. It is only against the terrible cruelties inflicted on them by the State and the companies in gratification of their greed for rubber and ivory that the natives stand in need of protection; otherwise they could take good care of themselves. It is, however, not quite clear to me in what way the Commission hoped to better the lot of the natives by "protecting" them; but 
the State seemed to fear the awful results that would arise, and practically quashed the whole thing. It takes little to scare an evil conscience.

At Equateur I went ashore and paid a visit to the extensive coffee plantations which are being worked under the direction of the so-called "agronomes" in the service of the State. Like the rest of its undertakings, the coffee plantations do it little credit, and are, of course, linked with the usual barbarities.

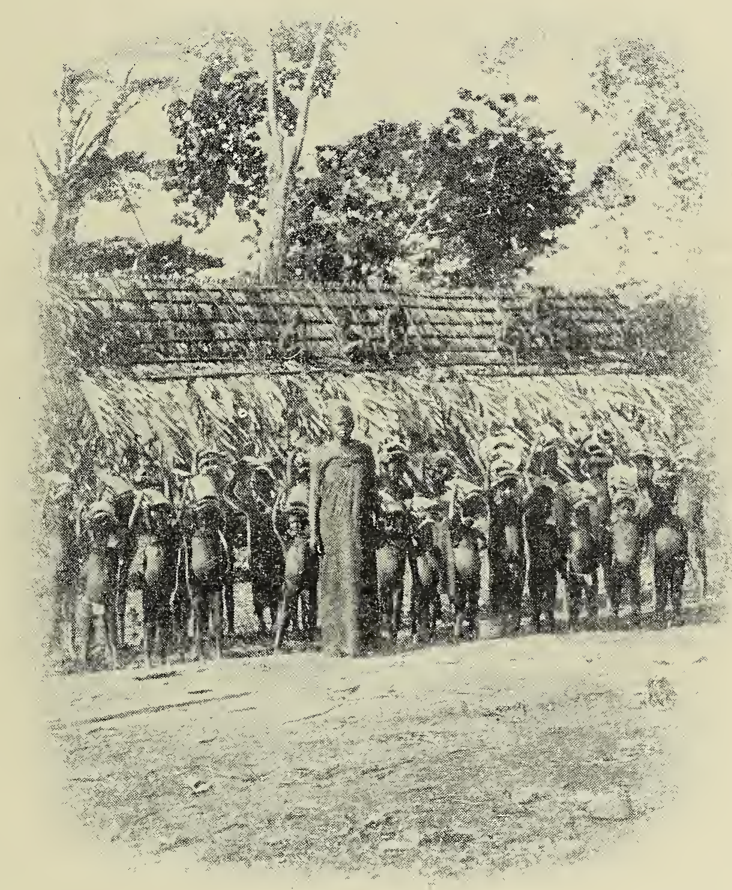

NATIVE WAIFS AND STRAYS AT R.c. mission at ibenio.

The very system of labour is characteristic of the Free State's method of employment, and will strike the casual observer as deserving of another name. Most of the workpeople are women, and nearly all of them have been taken prisoners in war at one time or another-mostly, I should think, in the punitive raids, which are small expeditions sent out to destroy a village when its chief has not sent in enough rubber or ivory 
to satisfy his task-masters. When these expeditions go out to punish the refractory native, their method is to surround the village, attack it, shoot the men and such of the women as try to escape, and then take the rest prisoners and send them down to the various stations. The village is then wiped out, and all trace of it is soon lost in a tangle of tropical vegetation; the able-bodied prisoners become practically slaves on the coffee plantations under the State officials; the children are drafted down to the Catholic missionaries to be educated in the rudiments of Christianity and civilized vice.

This is the only means the State has of securing labour for its plantations, as the rate of pay naturally will not tempt

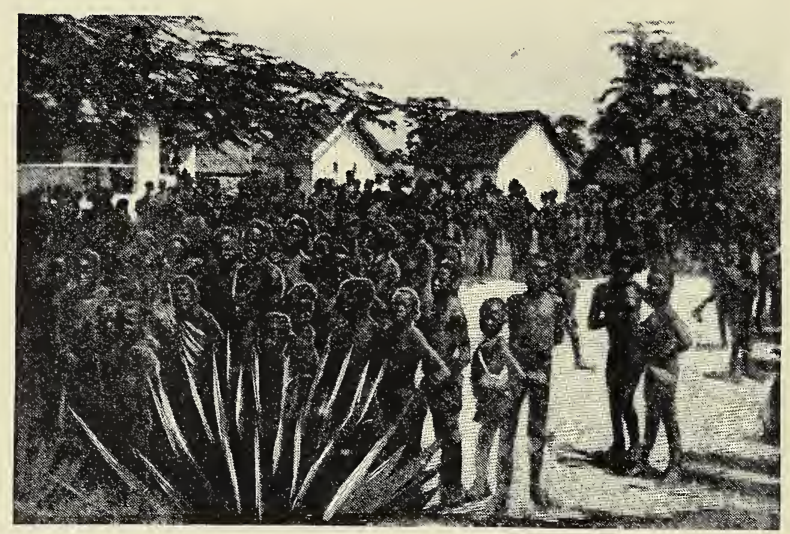

PAY-DAY.

the women voluntarily-especially as they are liable to be punished in all sorts of ways for the slightest deficiency. The women are paid from four to five francs a month and receive rations of food. Their pay is made over to them in kind-cloth, beads, brass, etc.-and the rate at which it is reckoned is twice its invoiced value. Naturally the natives will not let their women go away and work for the white man on such terms as these. Woman-looked at from the native's point of view-is the most valuable property he possesses, and he can make more by keeping her at home and employing her himself. The State's terms of employment, moreover, include an indenture of seven years, which makes it still more difficult to persuade the native woman to come 


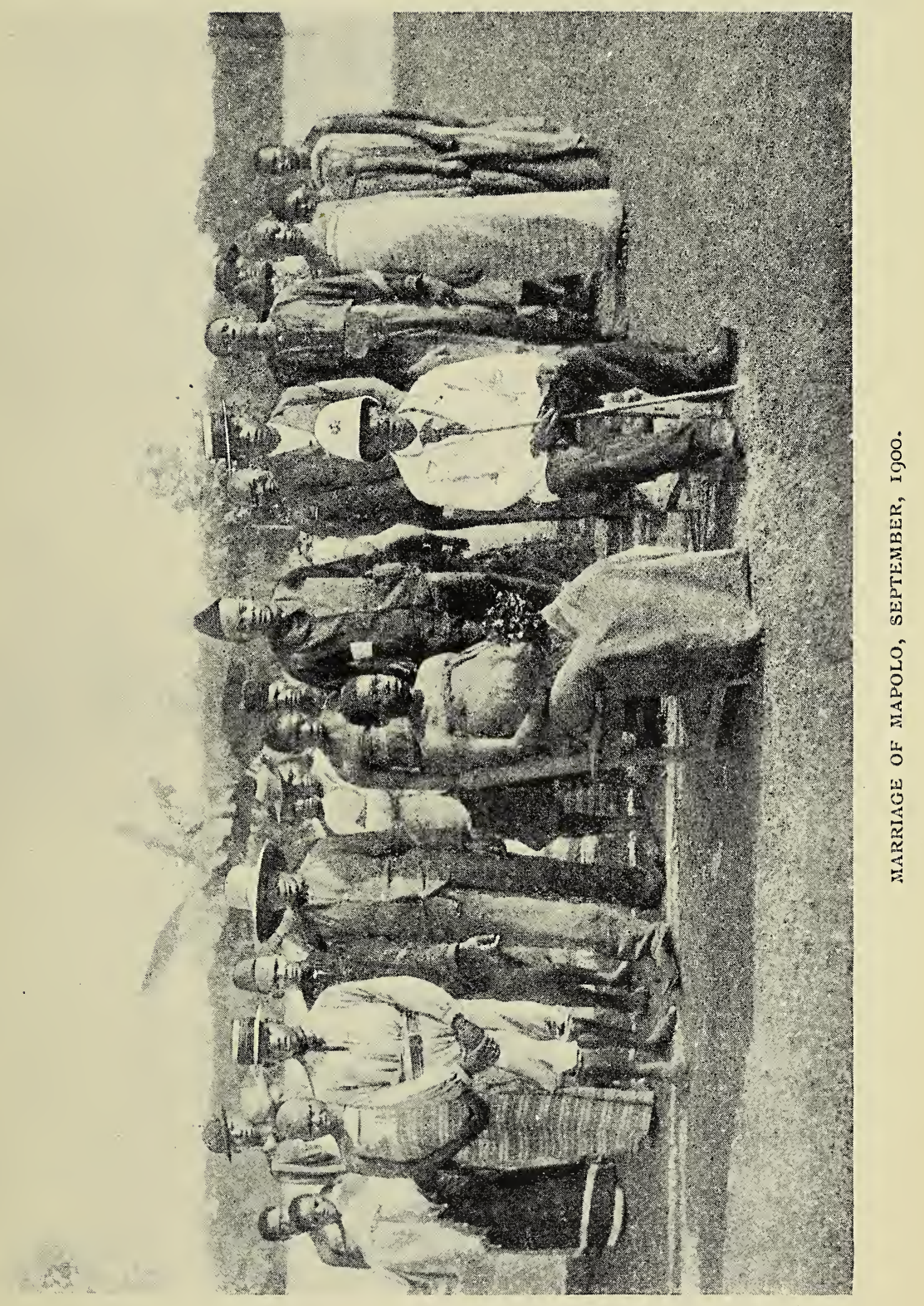


in voluntarily. That does not trouble the State very much. If labour is wanted labour must be obtained, so an expedition is sent out to "round them up" if the supply from the rubber raids falls short of requirements. But rubber raids are now so frequent that it seldom does. Of course, the women rarely return. As a rule their kinsfolk were wiped out in the raid in which they were captured, and probably where their village once stood is now a mass of bush and scrub. Besides, seven years is a long time to the native mind, and old surroundings and memories soon become obliterated from their not very receptive mental tablets. A good

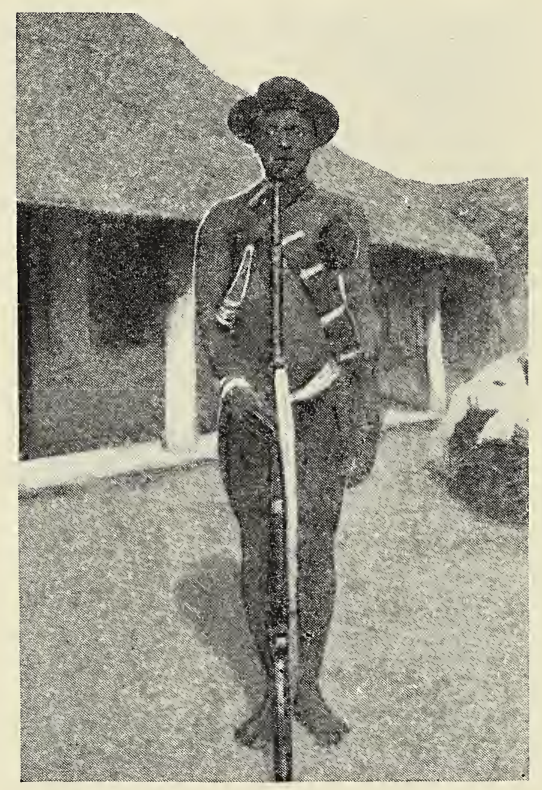

A CAPITA.

many die ; many more marry soldiers; a few are "taken under the protection" of white men. Possibly, too, their villages, if existing, are at the other end of the country, a thousand miles or more distant from the station where they have worked-and the State undertakes nominally the obligation to repatriate the women. If they attempted to wander home there would be an end to them, for they would sooner or later be killed in the bush and eaten by one or other of the cannibal tribes through whose district they would have to pass. So a great many of them re-engage, having 
nothing better. Out of slavery they feel homeless, as did the freed slaves of America when abolition became a fact.

One woman I knew returned home after her seven years had expired. She had been of a frugal turn during her period of engagement, and had amassed what was to her great wealth "under white protection"-quite a lot of cloth, beads, and bangles. She had a curious way of signalizing her return, for she bought two slaves from a local chief, had them killed, and washed herself in their blood. It was the acme of extravagance-like lighting a pipe with five-pound notes.

It is difficult to say what will be the place of Congo coffee in the market of the future. At present it has no place at all, partly because the rate of transport is so high, partly because of the laxity and want of capability on the part of the Belgian cultivators, and partly (perhaps in consequence) because of the expense attaching to the cultivation of the plants and the unwillingness of the State to spend money on proper tools. I have the advantage of possessing copies of most of Mr. Malet's Reports on the various stations. Speaking of the plantations at Limputu, Mr. Malet says, in his Report:-

"Considering the nature of the soil, the weeds have been well kept under. Even since my arrival here a month ago much has been done. This is chiefly because the 'chef de culture' here is the only man I have yet seen who knows anything about his work."

This sounds like high praise; but it may be seen how much the "only man" knew, for Mr. Malet has to say, in the next breath-

"The older trees are in a disgraceful state, never having been pruned since they were planted. I have no hesitation in saying that were fifty pruning knives or secateurs to be sent here, the result of pruning would be to more than double the crop. The trees have become so 'matted ' that no sun can get at the bearing branches, and consequently the coffee is prevented from flowering." Speaking of Barumbu, in the Aruwimi district, Mr. Malet says: "This is the one bright spot in this district where an experienced planter could make a successful paying plantation." But, like the rest, it is starved in labour, tools and machinery.* 


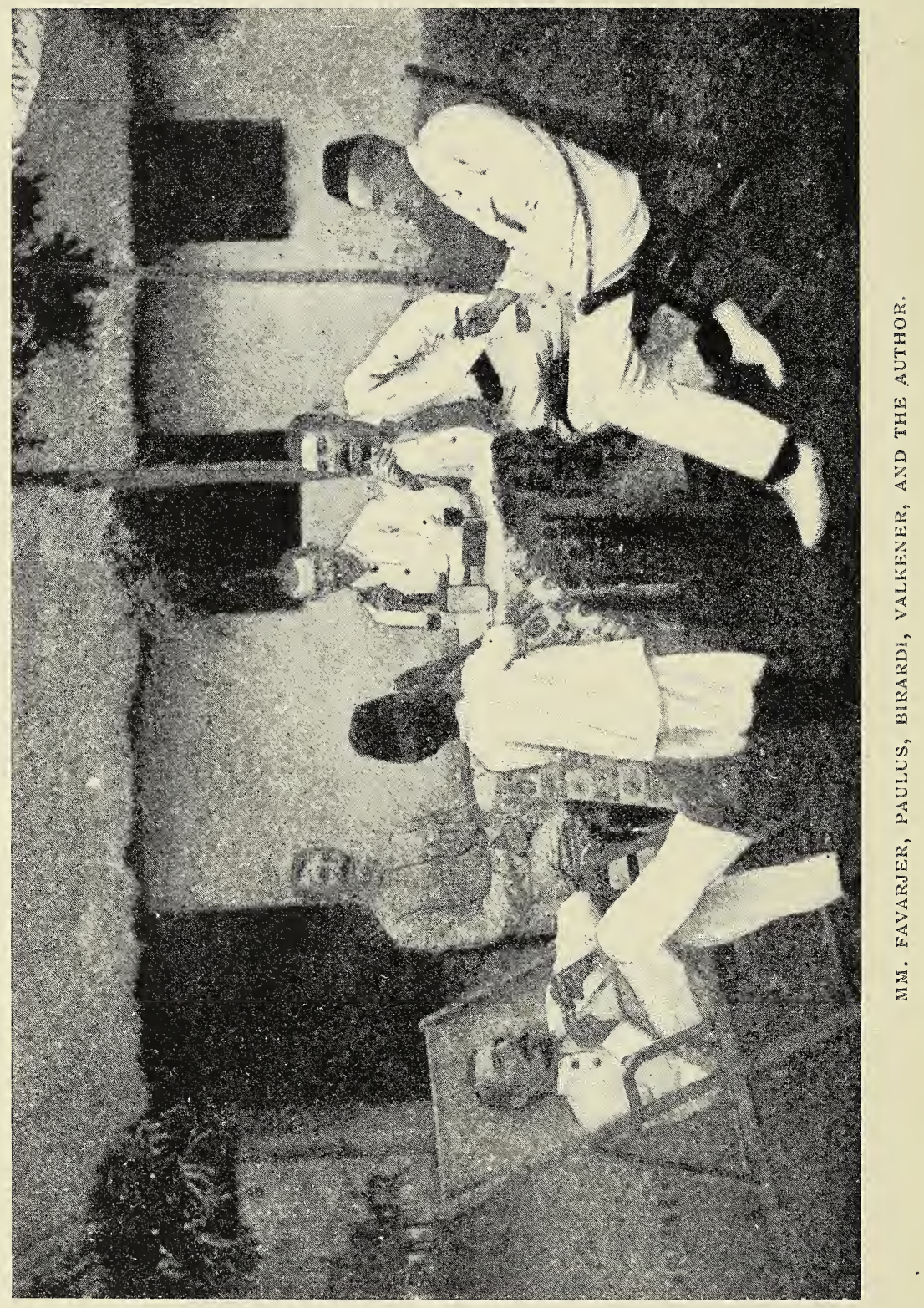


This is how Mr. Malet describes the work of the Belgian colonists at the Mogandjo coffee plantation:- "I regret I have to remark that the preparation of the land for coffee has been most scandalously done. Trees have been left standing in clusters, many of them positively harmful to any cultivated plant, and without any regularity or system, so that in places the coffee is far too thickly shaded, and in others there is no shade at all. The brushwood or undergrowth has been most carelessly cleared, the roots not having been properly exterminated, so that now in certain parts of the plantation it has grown up

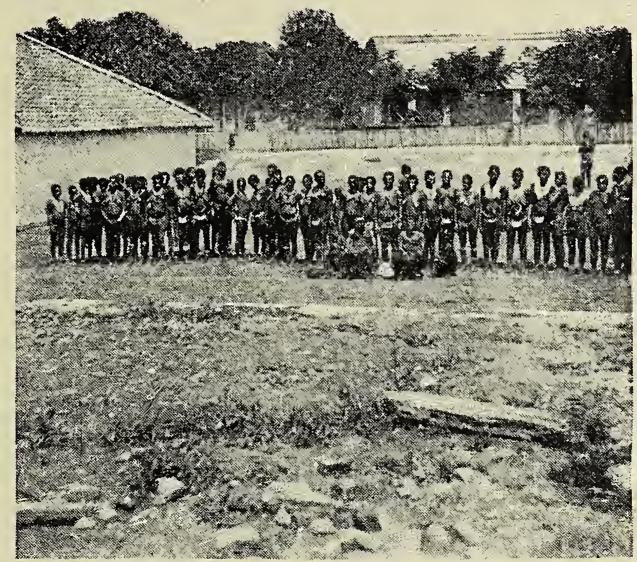

HOMELESS ORPHANS.

again nearly as thick as the original; in fact, the clearing of the place shows that whoever did it knew nothing of his work." Cocoa was attempted in this place also, and $\mathrm{Mr}$. Malet took occasion to report on it. "By a curious contradictory state of affairs," he writes, "the cocoa, which it is absolutely necessary to shade, has been planted in the only place where all the trees have been cut down, whereas the coffee, which requires no shade, has it. The trees have a miserable straggling appearance, and the leaves are, without exception, eaten to shreds by insects. The soil is not rich enough for the successful cultivation of this product." 
Of Yambuya, where an extensive coffee plantation has been laid out, Mr. Malet had some pointed remarks to make, which let a flood of light upon the intelligence of Belgian men and methods: "The top soil here is nearly pure sand with a small amount of humus on the surface, the sub-soil being a stiff yellowish clay. I caused several holes to be dug in various parts of the plantation. In each case water was met with generally at the depth of a metre, and in no place deeper than one and a half metres, thus proving the whole place to be unfit for the cultivation of plants whose tap-roots would penetrate that depth." It will strike the casual reader that the Belgians, before sinking their money on the laying-out of the plantation, might have assured themselves of this fact. But that is their way; they prefer to colonise in ignorance and brutal stupidity, and, as in other cases, they are generally obliged to call in English experience in the end. But in this case it did not seem to matter that the ground was bad, for Mr. Malet had the same report to make with regard to the state of the trees, shade and insects. Speaking of the weeds, he writes:- "The weeds here are very rank, and in some places so high that the young coffee cannot be seen. Two causes can be assigned for this state of affairs, viz. : lack of labour, and ignorance on the part of the responsible men as to the methods to be followed in weeding a tropical plantation." This, in fact, sums up the whole story of Congo coffee cultivation, and I do not think the European market has much to fear from its competition for the present. Mr. Malet might make a success of it if the State lets him alone. But the State is not fond of letting its men alone if they happen to be Englishmen. 


\section{CHAPTER IV.}

The Trading Companies-Their Constitution Under the State--The Share the State Holds-Their Objects-The Support they Receive from the State-Their TroopsTheir Officials - Their Liability to the District Commissioners-Responsibility to the Government-Their Relations to the Natives-Their Methods of TradingHow the Rubber is obtained-How the Ivory comes in-Do They go in for Anything Else?-Have They ever tried Mining?-Any Success?-What Chance of Profitable Gold Mining is there in the Congo?-Precious Stones-Attempts to Bribe State Officials-Cruelties on the Part of the Traders-Connived at by State Officials-Participated in-Proofs.

In spite of King Leopold's frequent assurances that "the only programme of the Government of the Congo Free State is the work of moral and material regeneration," I am inclined to think, after the experience of several years' residence in the country, that moral regeneration on the part of the State is non-existent, and that the material part of the programme is a euphemism for commercial operations on a stupendous scale. It has been my duty in the past to act as an official in certain of the branches of the State service, during which I was brought into contact with its methods of material regeneration-for of anything moral in the Congo Free State I am still ignorant. The great trade of the country is rubber and ivory; as commissioner of a district in the past I claim to know something about both, for I may say, in starting, that the State works its business affairs through the agency of its civil and military administrators, and encourages official zeal with such rewards as commissions on sales.

Before going into details, however, as to the methods employed by the State in its present trading operations, it is necessary to dip into the past history of the State, and to follow out the growth of its system from the time when it gave solemn pledges to the European Powers at the Berlin Conference, and promptly 
drove a coach-and-four through the whole purpose of the agreement; for the idea which dominated the spirit of the Berlin Treaty was a fair field and no favour for all comers in the domain of Congo trade; and if anybody is mistaken enough to imagine that any such purpose dominates the administration of the present-day Congo Administration, let him apply to the Government for the most ordinary information concerning the trade of the country, and note its answer.

The Government of the Congo Free State must have been composed of some very keen-sighted individuals when it first came

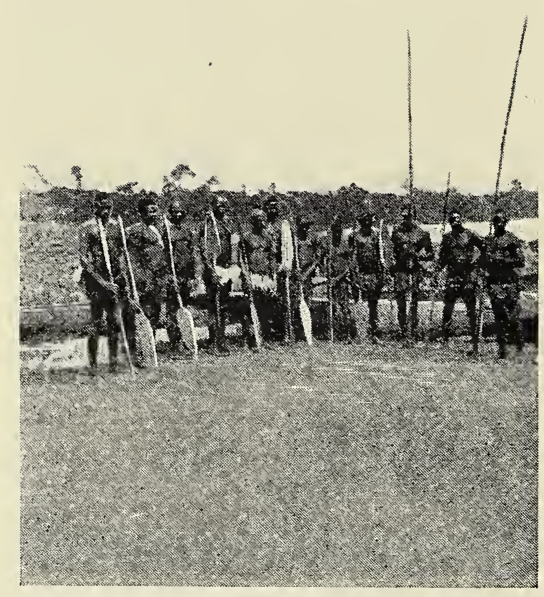

NATIVE PADDLERS.

into existence-people, or a person, who knew its possibilities and were able to appraise its tremendous value as a monopoly. It went to work slowly; there was no undue haste in its operations, and it was not foolish enough to make its steps more public than could be helped; and, on the other hand, it lost not a moment of time. The Berlin Treaty was ratified in 1885 . In July of the same year the State issued the first of a series of decrees, all of which I think must have been in the mind of the individual who formulated this, and all forming part of a definite line of action, with definitely 
thought-out results. In this first decree the Government took the precaution of declaring proprietorship over all lands vacant in the territories of the State. Now, the territories of the State were about a million square miles, and were estimated to contain a black population of some thirty-five millions. In some parts of the State at that time no white men had ever been, and it was therefore necessary to declare what particular meaning attached to the word "vacant." The State chose to attach the narrowest meaning possible. Vacant lands were explained to be those not actually occupied; and lands not actually occupied were explained to mean

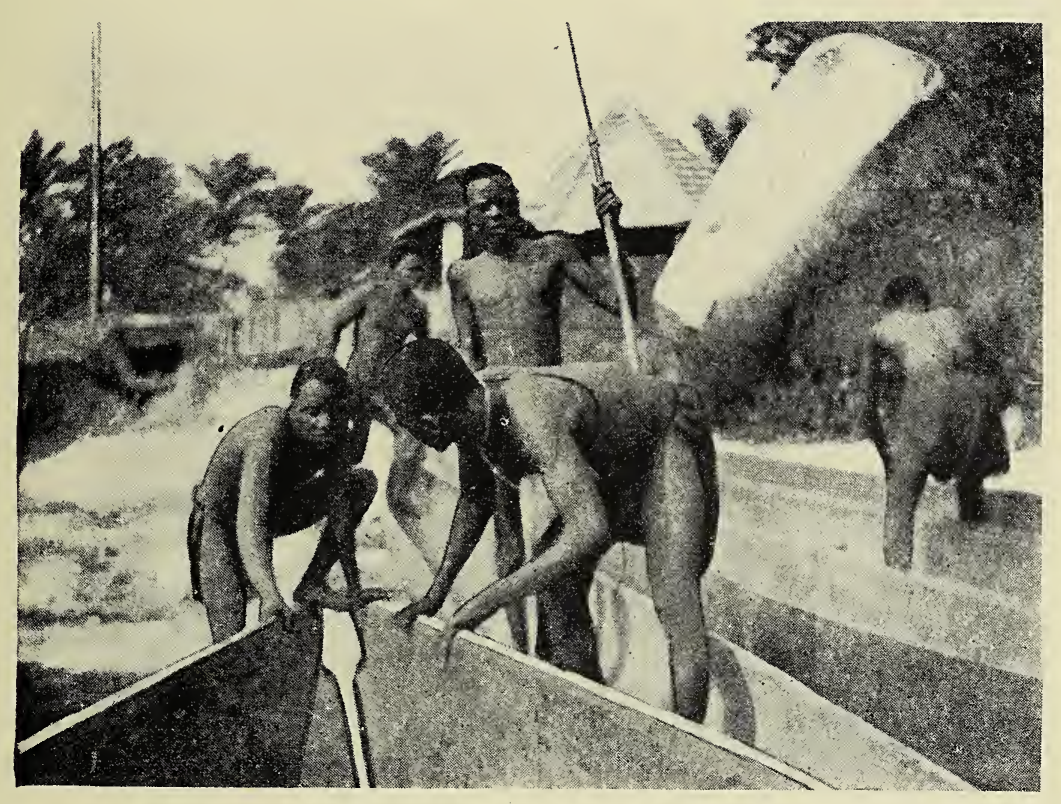

NATIVES EMBARIING.

lands not built over or cultivated. These lands were known by the term Terre Domainiale, and are mostly called the Domain Privé.

Now, the long-sighted individual who directed the State policy at this time did not embark his Government in a huge territorial responsibility simply for the purpose of providing it with something to do. The State, having acquired by a few words the sole rights over a million square miles or thereabouts, set about putting these territories to some definite use, prompted perhaps by the fact that 
they contained enormous wealth that would pay for the exploiting. There were, however, a few disagreeable competitors, followers of the pioneers who had shared in the early perils of the discoverers who paved the way for the State. This was not a business to be shared, and therefore all rivals, all competitors, or people likely to have unpleasant views on the subject of legitimate trading methods, had to be got out of the way. It was a matter of no great difficulty, provided it was done with a certain amount of reasonable care. On the 17th of October, 1889, the State issued a decree forbidding the working of rubber for private enterprise. It was a very cautious step. The State as yet claimed nothing for itself, but merely acted as though it were trying to regulate the traffic in the two great sources of its wealth; for by this decree merchants were allowed to trade in rubber and ivory with the natives, but were prohibited from tapping the trees and vines in an organised way, and were not allowed to hunt the elephant for the purpose of securing ivory. Thereby trade was allowed, but exploitation and cultivation were forbidden.

That was the thin end of the wedge, which in the following year was driven in a little deeper. It was not at all difficult, the way for the next step having been carefully prepared. The State openly asserted its right to trade, in direct violation of the terms of the Berlin agreement, and issued this information at the psychological moment when Europe was far too busy with other and more internally interesting affairs to trouble about the sacredness of a treaty that had lifted it out of an unpleasant difficulty. So the State entered into open competition with the merchants it had allowed to trade with the natives but not to exploit the country.

But anybody could trade on equal terms, and the State, naturally emboldened by the success of the campaign so far, began to look for something better. Rivals were still in the field, and might easily be restricted still further. So the way to wealth was lightened by the imposition on traders of a tax ranging from two to four francs a kilogramme on ivory bought by merchants from natives. It was an absolutely crippling tax, and certainly had the desired effect. One of the State's biggest competitors in the ivory business was the Nieuwe Rotterdam'sche Handels-Vernootschaap, the Dutch Africa Company with its 


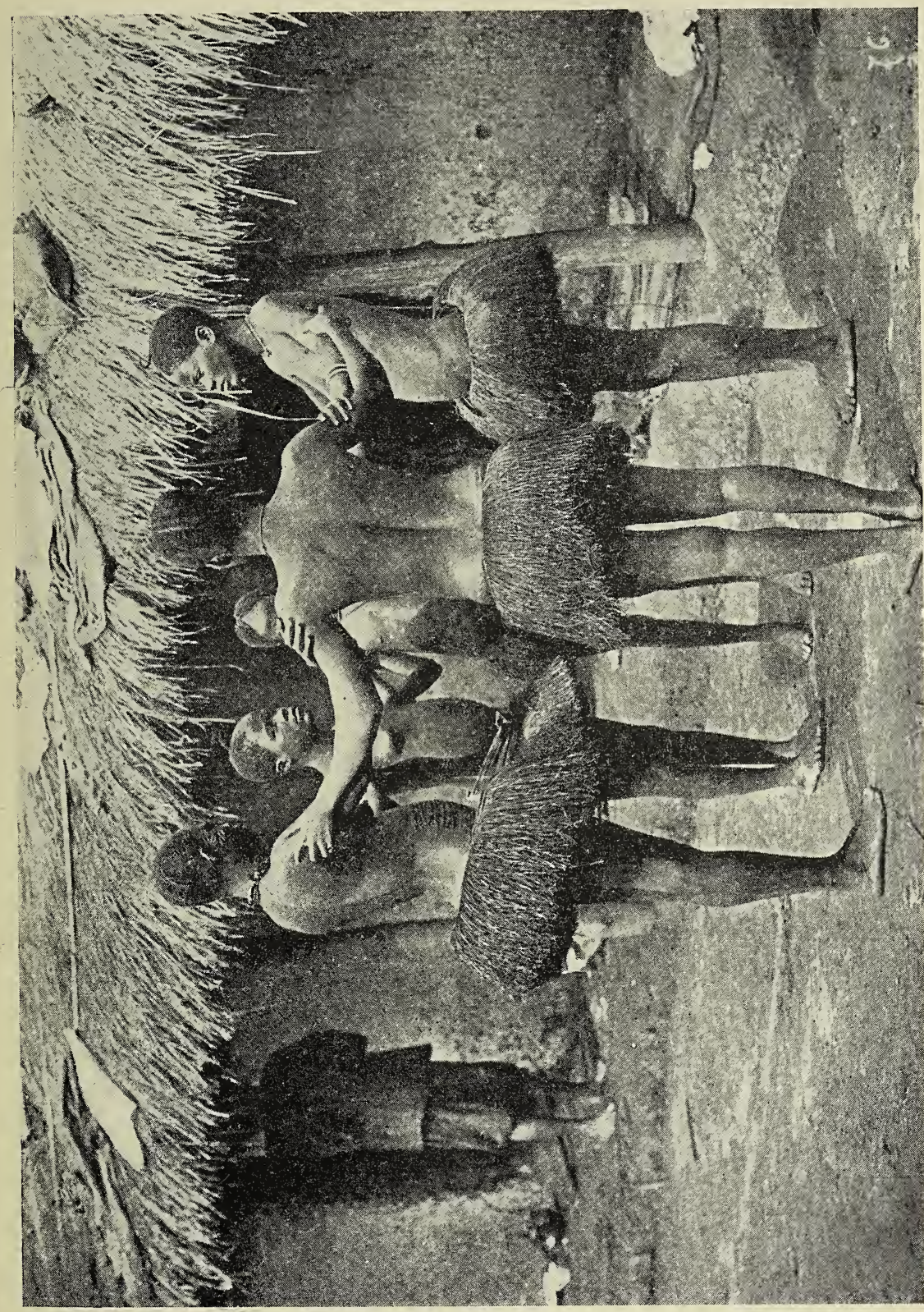


headquarters in Rotterdam. The Dutch company was unable to compete in the market on such terms; and if a coporation with the capital behind it that the Dutch company possessed was defeated, it may readily be concluded that the smaller rivals of the State had a poor chance. In point of fact, the State swept out of its path one of the only two serious rivals it possessed.

The other gave it more trouble. The Congo Arabs far up country, who had been accustomed to trade in rubber and ivory for many years by Nile and East African routes, recked little of proclamations issued by interloping white men; and the Belgians soon found that it wanted something more drastic than taxes to remove these determined traders from the field of operations in the upper Congo. Accordingly, having great faith in their army and their own powers, they started off to wipe out the Congo Arabs. In the end they succeeded--how and by what methods has been well told by Mr. S. L. Hinde in his book "The Fall of the Congo Arabs." With the help of the Batatela tribe the Arabs, after long and costly operations, were cleared out, and the State had the trading field practically to itself.

The next move was a corollary of the second decree. This document was never published officially, since it really pretended merely to enforce an existing decree. In September, 1891, however, the following circular was issued; it set forth that the district of the Welle-Ubanghi was State domain, and it was signed and forwarded by Lieut. Le Marinel, who was then commanding the State forces in that district:-

"I have the honour to inform you that I have decided to enforce rigorously the rights of the State in its domains, and in consequence cannot allow the natives to convert to their own profit or sell to others any part of the rubber or ivory which forms the fruit of that domain. Traders who purchase, or attempt to purchase, such fruits of the domain from the natives, which fruits the State only authorises the natives to gather subject to the conditions that they are brought to it, render themselves in my opinion guilty of receiving stolen goods."

Two points worthy of note arise out of this document; they are: (1) The State had claimed only such lands as were not actually cultivated; (2) the State had already, after the decree mentioned 
in (1), allowed the merchants to trade with the natives in rubber and ivory, and had merely forbidden the actual exploitation of the country.

Naturally the companies were not going to sit down quietly under the slow, but obviously dishonest, methods the State was adopting in order to oust them. The astute individuals who were at the head of affairs were suavity itself. The traders protested. The State was very sorry that any misunderstanding should occur, and hoped meanwhile that a modus vivendi would be arrived at whereby the rights of the State might be respected, while at the same time the merchants might be given a sphere or spheres in which to conduct their operations. It was almost an invitation on the part of the State to come into partnership with its rivals who were making themselves unpleasant; and that, in fact, was really what in the end did happen. The immediate result of the merchants' protest, however, was to give the State a chance of defining its position while giving it, at the same time, a friendly warning not to proceed too quickly. And in this very definition the State went a step further, for it assumed the validity of the circular issued by Lieut. Le Marinel, and proceeded to apply it to all those districts from which free trading was excluded.

The definition amounted to the division of the State territories into three zones, and they were described as follows :-

1. A zone in which the harvesting of the natural products (rubber and ivory) is reserved for the exclusive benefit of the State, and is known as the Domain Privé. This zone is closed to all private enterprise.

2. A zone in which the method of harvesting the rubber and ivory and other products is to be decided when circumstances permit, and in which the State enjoys a free hand, while private enterprise is barred from trading therein.

3. A zone nominally open to private enterprise, but in which the State levies the rubber and ivory taxes at the rates previously mentioned.

On the face of it this will strike most thinking people as a very bad arrangement, even though the State domain should be so small as to be merely nominal. This, however, is very 
far from being the case. In point of fact the State has apportioned to itself the lion's share even of this iniquitous arrangement, for the geographical arrangement of the zones has been planned so cunningly as to leave the really valuable districts in the hands of the State; and, of course, territorially speaking, the State has reserved for itself by far the largest domain. Indeed the domain devoted to free (and not very free at that) trade is absurdly small, and hedged with taxation and restrictions. First of all the Domain Privé, Zone 1. This takes in the basins of
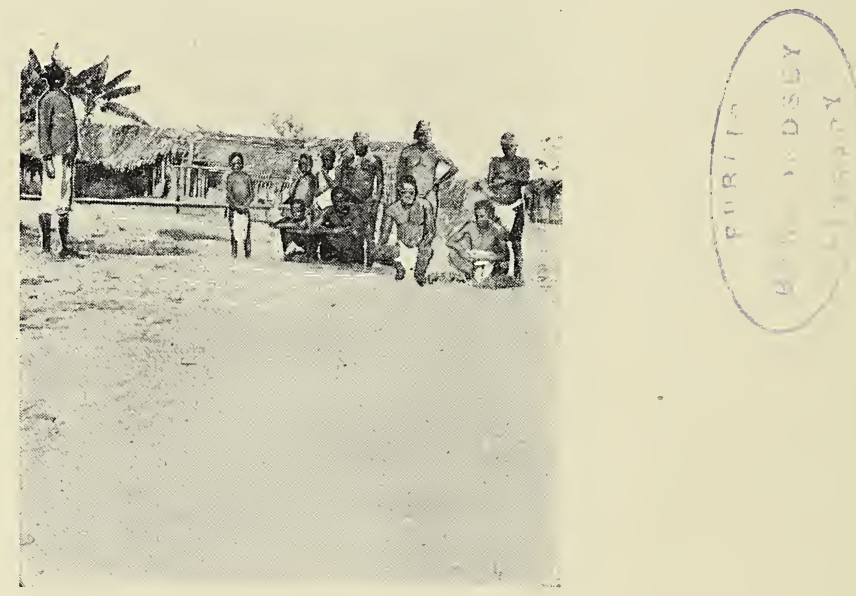

NATIVES.

the Bomu Welle, Mongalla, Aruwimi, Itimbiri, Lopori, Maringa, and Lukenie rivers and the two lower lakes, Leopold II. and Tumba. In this region only the State is allowed to trade. Zone 2 includes the basins of the Lomami, Congo-Lualaba south of the Falls, including Katanga, Urua, Manyema, and Lakes Mweru and Kiva. The third zone-that which is open to private enterprise subject to taxation-includes the Lower Congo, the Cataract region and the Mayumbe; the banks of the Upper Congo as far as Basoko, except between Lukolela and Equatorville; by 
the left bank of the Ubanghi up to its junction with the Bomu; and the basins of the Ruki, Ikelemba, Lukungu till the Lopori, and the Kassai.

A glance at the map will show the inner meaning of this arrangement; by its means three-quarters of the State territory is closed to private enterprise. Throughout the greater part of the rest, which is split up amongst various monopolist companies, the State imposes rubber taxes on the natives.

Having thus defined its position, the next step was for the State to get to work and make it pay. By "making it pay" the

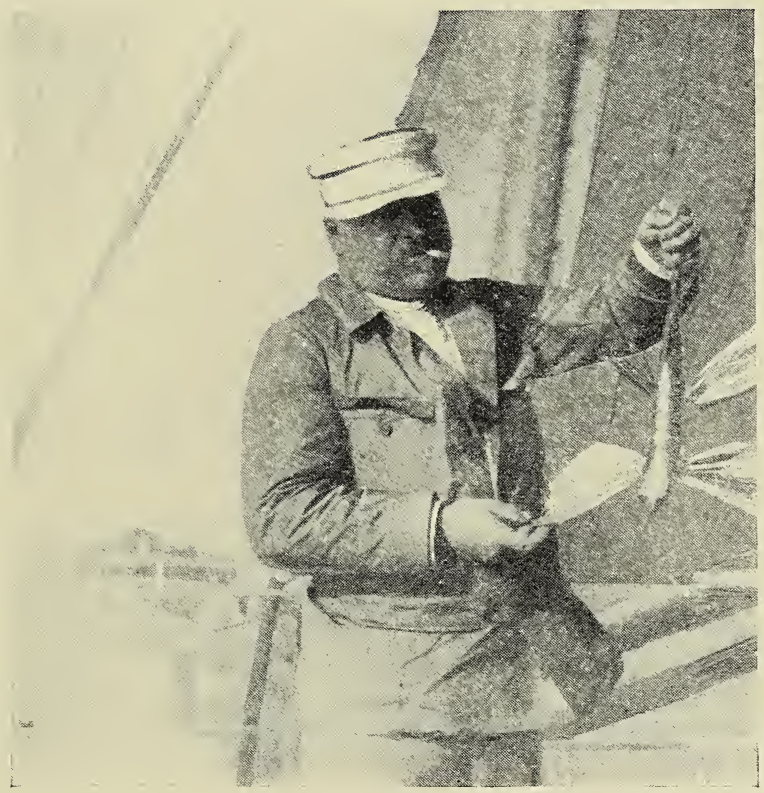

CAPT. LARDY (SWISS), killed at sungula.

astute heads of affairs did not mean that the Congo State should show a substantial financial balance at the end of the year, such substantial balance to be devoted to the welfare and improvement of the country. In point of fact it had nothing so quixotic in mind, and "making it pay" was to be interpreted "put money into the pockets of King Leopold and those who had the fortune to share with him the direction of the Congo government." It was high time that this should be done. At the end of 1892 the period for plotting and arranging was properly at an end; it was time to reap 
the fruits. The Government saw itself face to face with a most unsatisfactory budget. Money was scarce, and money was wanted if the carefully-laid schemes that had been prepared for the future enrichment of the heads of the State were not to be frustrated. The Arab war was in full swing, and, since the Belgians had not found it the walk-over they had imagined, it wanted further financing. The subsidy was gone, and the State was in debt to private financiers, its credit too heavily pledged, and itself too compromised to permit of retreat.

The long heads that had devised so cunning a scheme that had brought the State to such a point were not likely to be defeated by such a temporary difficulty. A further loan was raised; the future was still further pledged; and meanwhile schemes for reaping the harvest of the preparations that had already been made were taken in hand at once. Two plans were devised:-

1. A scheme of direct taxation called "imposts paid in kind by the natives." This applied to all natives throughout the State, whether in the Domain Privé or not.

2. The constitution of companies to work the Domain Privé.

The taxation may be first examined. Imposts paid in kind, so far as I am aware, are not any fixed taxes, but what the State officials think sufficient. The taxes are applied absolutely indiscriminately, and without any system except this, that each district must produce so much rubber and ivory, no matter who pays it. As may be expected, the natives did not submit to this without some objection. It is easy to understand the native's dislike to work at high pressure for rubber and ivory in which he has no further interest than the thought that it will save him from being visited by the State soldiers, armed with ball cartridge and orders to shoot it-and the possible chance of eating their victims after the fight. The conditions of the tropics, as known to the native before the advent of the white man, were such that he was really obliged to work only about two months in the twelve in order to keep himself and his wife; if he worked more he got rich, or at least his tribe did, for, of course, communal conditions reigned among most of the tribes. Now he began to see in the rapacity of the white man a menace to existence as he understood it. In the parts of the State which adjoined French territory he soon got to 


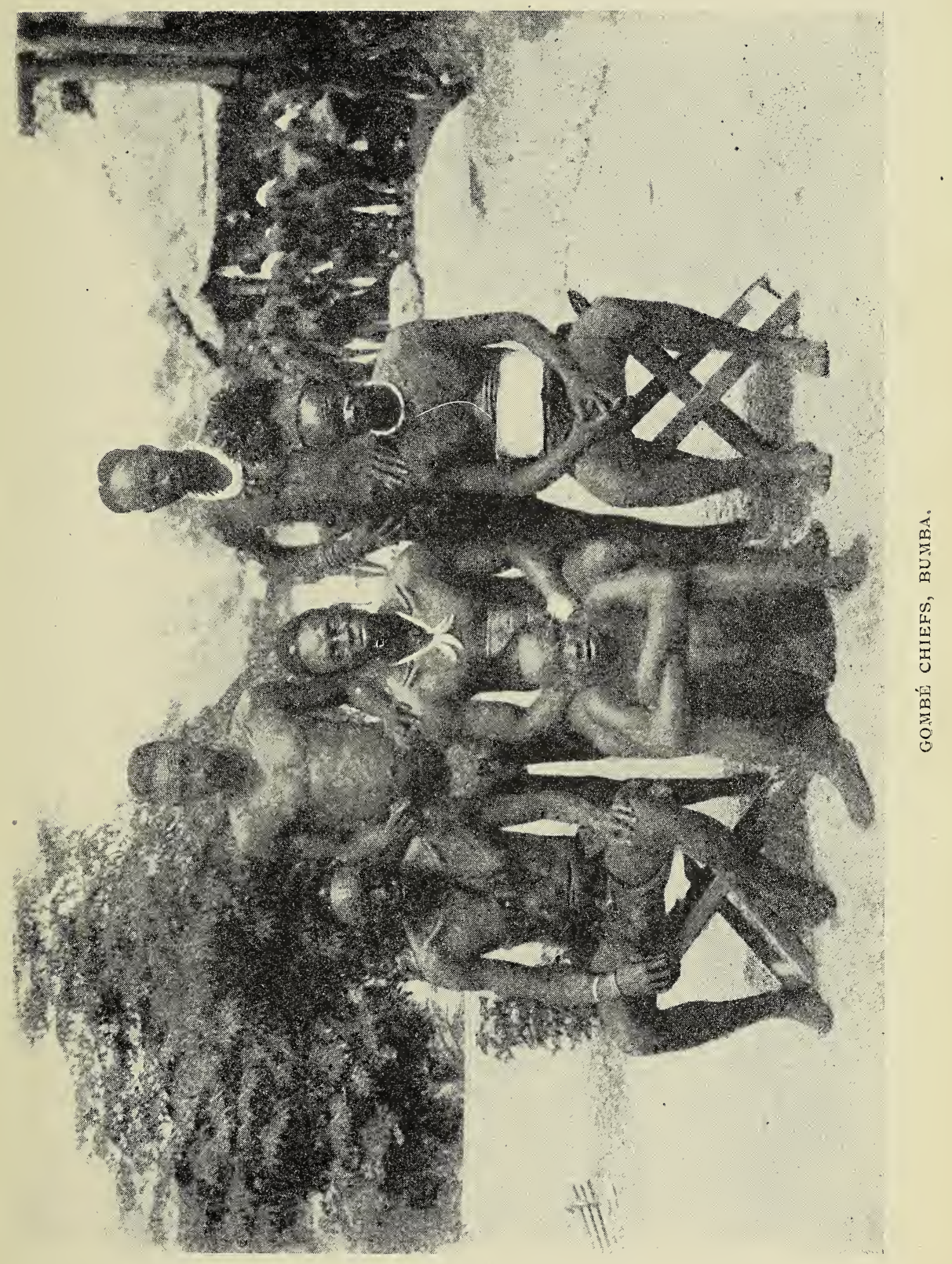


know the difference between the Frenchman and the Belgian in the methods of the government; and all along the banks of the Lower Congo and the Bomu an exodus constantly goes on. The natives bolt whenever there is a chance, for they know that under the French they will not be bothered out of their lives for ivory and rubber. But in parts of the country they are not so fortunate as to have a handy frontier to skip across, and when they found they were expected to become the white man's slave, and their lives were a nightmare of rubber collecting for the white man's benefit, they began to wonder "where they came in." They had no option; rubber or bullets, ivory or cold steel were the alternatives. And often enough there were not even these

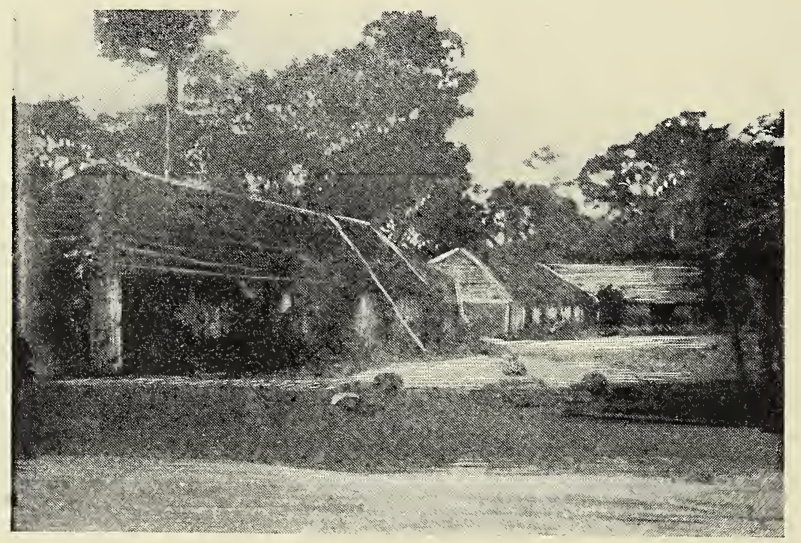

RUBBER SHED.

alternatives. Their taxes were limited by their ability to produce and the knowledge of their further inability to produce came to the State mainly when it was found that bullets and cold steel had no effect. "Proceed as far as possible by persuasive measures"-thus runs the order issued to the State officials. In the first place the words "as far as possible" are worth noting, and after them the words "by persuasive measures." It should be borne in mind that the commissioners are paid themselves out of the proceeds of this taxation-not altogether at a fixed rate, but only partly so. The regular salaries of the officials are absurdly low as pay goes for colonising in a tropical and unhealthy country such as the Congo. On the other hand, the main object of the commissioner being 
placed in a district is that he shall overlook the production of rubber-it is idle to talk of taxes in such a connection. So that, in addition to their slender pay, the officials have to make some income out of the production of rubber and ivory on the part of the natives; and the more they can extract from the unfortunate natives the better for them, as they are paid pro rata. The amount of their pay is therefore dependent on the amount of the rubber and ivory they can extract from their districts; and, as I said before, the amount is not fixed by the State, and the officials are allowed to use force in collecting. It can hardly be wondered at that every now and then the world is shocked by some horrible cruelty to the natives perpetrated by State officials. Considering that the very duties of the men involve

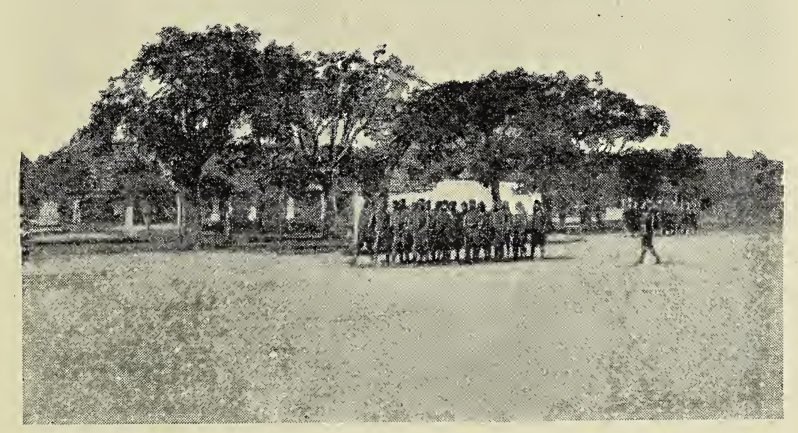

DRILLING.

the perpetration of acts of cruelty, and that they are daily familiarised with deeds which are unspeakable and indescribable, it will be agreed that it is not the man but the system which is deserving of censure. The usual excuse for excesses of this kind is that men living in a tropical climate are prone to acts which in a temperate clime they would shrink from with horror. This may be true; I do not know if it is. But if there is any foundation for it as a theory, certainly extenuating circumstances can be pleaded in the case of the man who commits the crime. None at all can be pleaded for the State, whose very conditions of service include the incitation to commit what must be morally called a crime; and if men are liable in tropical climes to commit acts from which they 
would recoil in more temperate climes, how much more are they likely to do so when their daily life is so constituted as to familiarise them with cruelty and repression?

Production, therefore, is limited only by the ability of the natives to produce. They produce just as much as the officials of the State can get out of them-which is mostly rather more than their country can be said conveniently to yield. What becomes of the money thus gathered? The amount of the tax being practically unlimited, and the amount received by the State being, for obvious reasons, kept out of official documents, it is impossible to say what is the revenue derived from this nefarious process. The State publishes no balance sheets on the subject, and volunteers no information as to the amounts raised; but it is possible, by checking off the State expenditure and comparing the sales of rubber in Antwerp with them, to arrive at some sort of idea where the money goes. The net revenue of the Domain Prive is supposed to be devoted to public expenditure. If that be so, the Congo State ought to have a pretty snug balance lying somewhere. But no accounts are published, so one can only assume that the net revenue, whicl: certainly is not to be found expended on the welfare of the State, finds its way into other channels. I shall have occasion to consider these later on.

The other part of the scheme which had been so carefully prepared in the years preceding 1892 was the establishment of companies to work the Domain Privé. They frequently reconstruct, and alter their names; but at the back of them is always the same set; and at the outset it may as well be said that they are really State concerns, since in nearly every case the State is the largest holder of shares. They are thinly-veiled State enterprises, and therefore the State is responsible for their conduct and results. These companies, working the two zones which are directly under State control, and from which free trading is excluded, are :-

1. The Société Anversoise du Commerce au Congo.

2. The Abir (originally the Anglo-Belgian IndiaRubber Company).

3. The Cie. du Lomami.

4. The Société Anonyme d'Agriculture et de) Plantations au Congo. Zone No. I.

5. The Cie. du Katanga. 


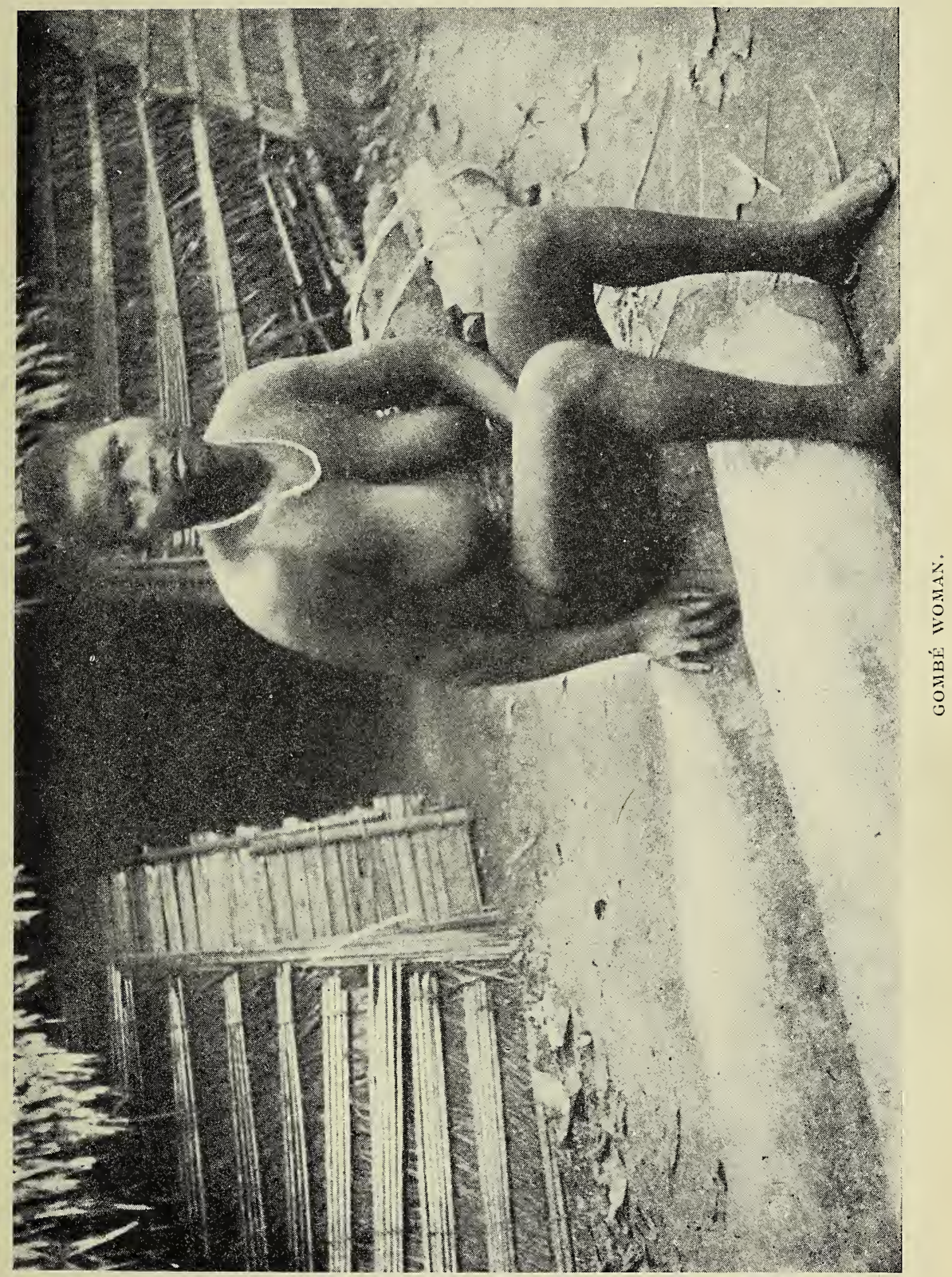


There is, besides, the Société Anonyme Belge pour le Commerce du Haut Congo. It is difficult to say exactly what is the district worked by this company.

As an example, let us consider the case of the first named. The Société Anversoise du Commerce au Congo was founded by royal decree in 1892. It was formed as a Belgian company, receiving from the State, for a renewable term of fifty years, the concession of the whole of the Mongalla region. In 1898 it was founded as a Congo company, its headquarters being transferred from Antwerp to Mobeka, in the Mongalla district. The object of this was to transfer also the responsibility of its agents from the Belgian to the Congo jurisdiction, it having been found inconvenient that the agents of the company should be answerable to the Home Government for offences committed in the Congo. Under the present circumstances they can only be tried in the Congo for offences committed there. By this means an agent who is guilty of a misdemeanour is liable to be prosecuted only by a government which indirectly employs him and is likely to benefit by his offences.

The original capital of this company was 400,000 francs; this was increased to $2,700,000$ francs divided into 3,400 shares at 500 francs each. Fifty per cent. of these shares are held by the State. The company pays the State a royalty of 300 francs on every ton of rubber exported, and five per cent. on the price realized on the Antwerp market for every ton of ivory shipped to Belgium. Therefore the State, as chief shareholder and participator in the profits and in the proportionate output, has a triple pecuniary interest. Moreover, the directors are appointed and are subject to dismissal by King Leopold. Lothaire (why he is called "Najor" I do not know, for he really holds no such title) is now a director, his appointment having been made subsequent to his dismissal from the service of the State in connection with the hanging of Mr. Stokes, the English trader. The net profits of this company in 1898-the last figures I have at my disposal-were $3,986,832$ francs; and it has to be borne in mind that the State is holder of half the shares. Later on I shall have occasion to define the term "State."

From the table on page 60 will be seen the part the State plays in the companies working the Domain Privé and the second 
zone. It would be idle to say that the State is not responsible for the actions of the companies' officials in their several districts. As a matter of fact, whenever any one of the companies' officials is charged with an offence against the State laws, very little trouble is taken by the administrative officials to have the offender removed. As often as not the man, after what must really be described as a mock trial, is reinstated in his old post, and goes back to continue his old work-the squeezing of rubber out of the natives for the companies - "by persuasive measures where possible."

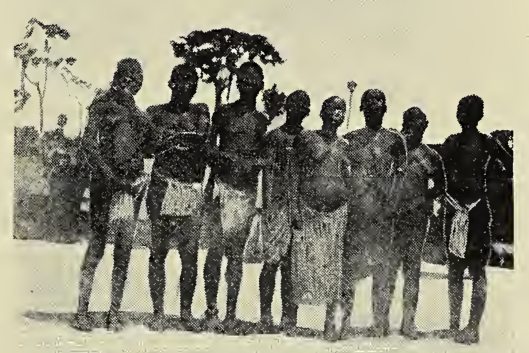




\begin{tabular}{|c|c|c|c|c|c|c|c|c|}
\hline \multicolumn{2}{|c|}{ 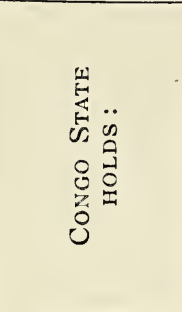 } & & 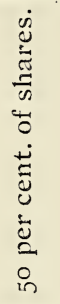 & 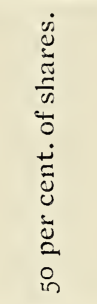 & 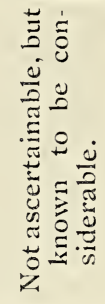 & 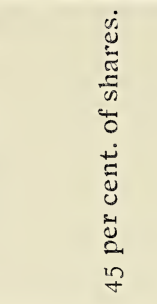 & 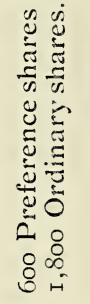 & 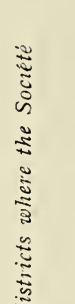 \\
\hline \multicolumn{2}{|c|}{ 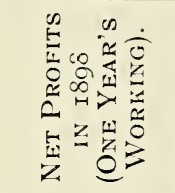 } & 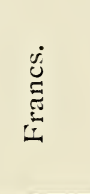 & $\begin{array}{l}1 \\
0 \\
0 \\
0 \\
0 \\
0 \\
0 \\
0 \\
0 \\
\dot{m}\end{array}$ & 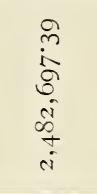 & $\begin{array}{l}\infty \\
\infty \\
\text { in } \\
0 \\
0 \\
0 \\
0\end{array}$ & 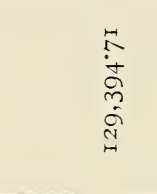 & $\begin{array}{l}0 \\
\stackrel{0}{0} \\
\dot{0} \\
0 \\
\dot{0} \\
\dot{m} \\
\end{array}$ & 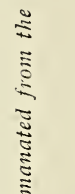 \\
\hline \multicolumn{2}{|c|}{ 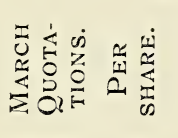 } & 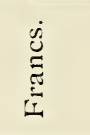 & 1 & 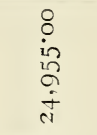 & $\begin{array}{l}0 \\
\stackrel{n}{n} \\
i \\
0 \\
0 \\
\dot{m} \\
\dot{m}\end{array}$ & 离 & 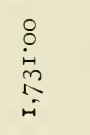 & 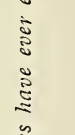 \\
\hline 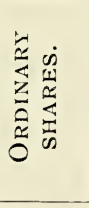 & 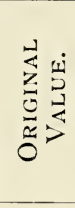 & $\stackrel{\dot{v}}{\ddot{E}}$ & 1 & 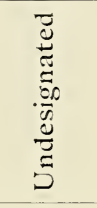 & 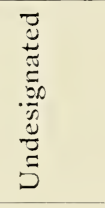 & $\stackrel{8}{\circ}$ & 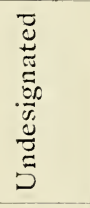 & 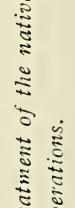 \\
\hline \multicolumn{2}{|c|}{ 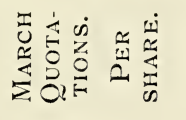 } & 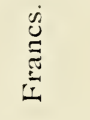 & 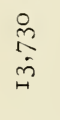 & & 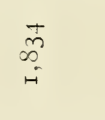 & & $\begin{array}{l}0 \\
\stackrel{\circ}{\alpha} \\
\stackrel{i}{i}\end{array}$ & 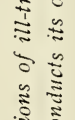 \\
\hline 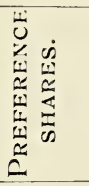 & 崖 & 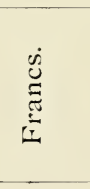 & $\begin{array}{l}\stackrel{8}{\text { in }} \\
\text { int }\end{array}$ & 1 & in & 1 & in & 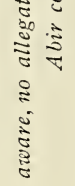 \\
\hline \multicolumn{2}{|c|}{ 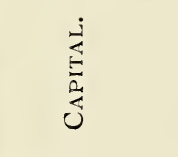 } & 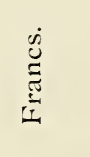 & 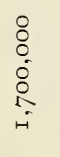 & $\begin{array}{l}\circ \\
\vdots \\
0 \\
\vdots \\
\vdots \\
-1\end{array}$ & 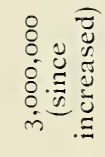 & $\begin{array}{l}\circ \\
\vdots \\
\vdots \\
\vdots \\
\vdots\end{array}$ & 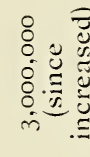 & 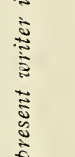 \\
\hline \multicolumn{2}{|c|}{ 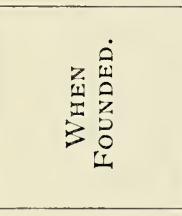 } & 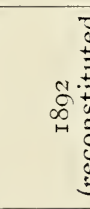 & & 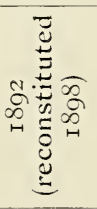 & 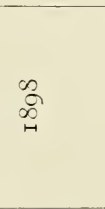 & 吕 & 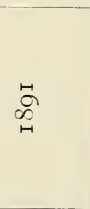 & 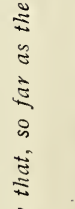 \\
\hline \multicolumn{2}{|c|}{$\sum_{z}^{\frac{1}{z}}$} & 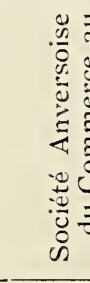 & & $\begin{array}{l}\vdots \\
\vdots \\
\vdots \\
\vdots \\
\overline{3}\end{array}$ & 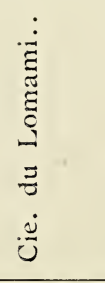 & 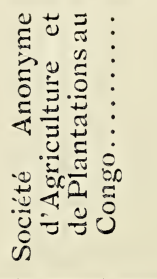 & 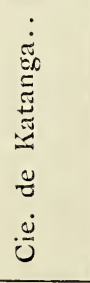 & 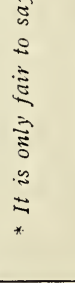 \\
\hline
\end{tabular}




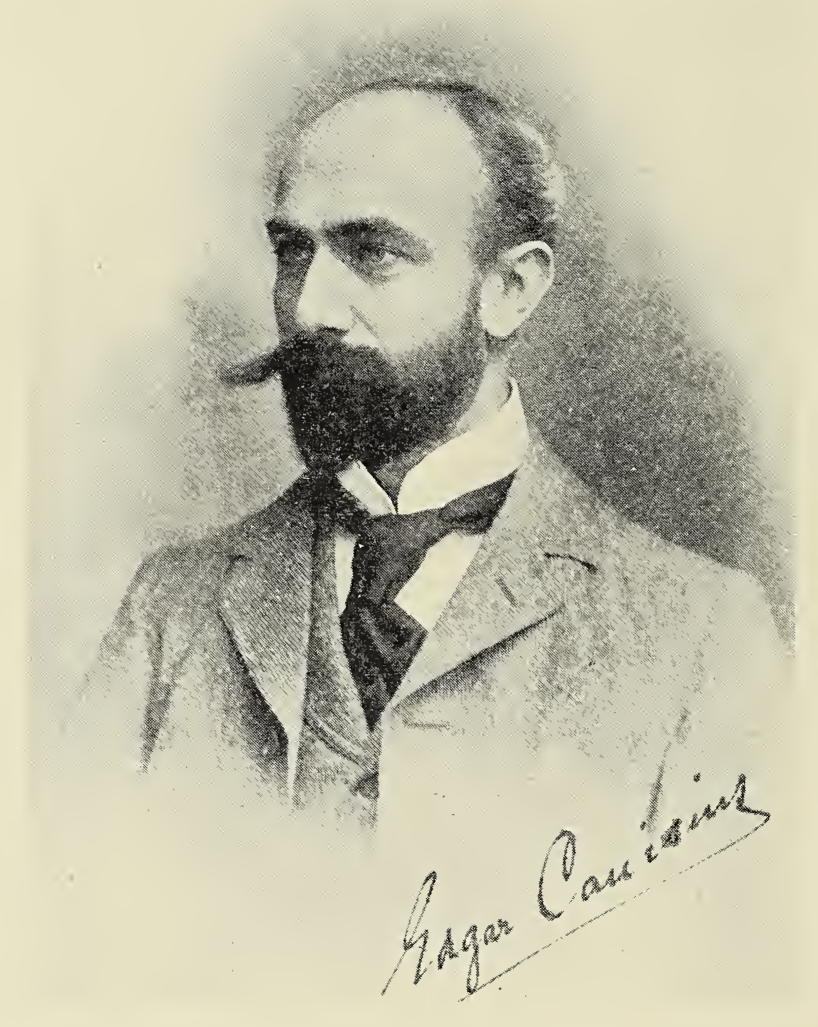

EDGAR CANISIUS

(formerly of the Congo State Service and the Société Anversoise). 


\section{CHAPTER V. \\ A CAMPAIGN AMONG CANNIBALS: THE RUBbER REgIME.}

BY EDGAR CANISIUS.

Through the Lower Congo by Caravan Route and Railway-Boma and its DelightsThe Matadi-Leopoldville Railway-The Steamers on the Upper Congo-A "Really Beautiful Yacht"-Callousness of the Belgo-Congolese-The Mongalla Concession-Detained at N'Dobo-_"Gathering" the Rubber-How the Natives are "tagged"-_"La Chicotte"--Tapping the Rubber-Vine.

THE year 1899 had almost run its course when I embarked at Leopoldville on board the Government stern-wheeler "Hainaut," bound for the upper reaches of the great Congo river and the interior of yet semi-unexplored, often idealized, and usually misunderstood Central Africa. As this was the second time I had been called upon to undertake such a journey, I was, unlike some of my companions, by no means surprised at the many and remarkable points of difference between the "Hainaut" of fact and the splendid, well-found vessel so glowingly depicted in official and semi-official documents. That there should exist such distinctions is but an illustration in petto of the discrimination which should be observed when dealing with all things Congolese. In no part of the world can be found such painful differences between promise and performance, grandiloquent phrasing and sordid and imperfect achievement. In the course of this narrative it will be found needful to often employ words of harsh and, apparently, unsparing criticism; this much, however, I will assure my readers --that no statement will be made which cannot be substantiated; no conclusion ventured which does not appear fully justified by facts.

I had, of course, travelled to Leopoldville from Matadi, the head of the navigation on the Lower Congo, over that "grande œuvre," the railway, which was yet only partially constructed at the time of my earlier expedition to the interior of King Leopold II's 
vast African possessions. I was certainly the gainer, as regards both comfort and economy of time; although, needless to say, the service of the Congo Railway includes neither "trains de luxe" nor "ffiers." Even in the late '90's it was usual, and indeed necessary, to keep employés of the State, appointed to posts in the interior, for many days or weeks together at Boma or Matadi until suitable opportunity offered for utilizing their services in connection with caravans or detachments of troops proceeding to the upper river. Thus it happened that, when I and other compatriots first arrived in the Congo State, we were detained for quite a considerable time at Boma, and finally left that place with several thousand Haussas and other West African tribesmen, then the mainstay of the military resources of the State.

It was certainly without sorrow that we turned our backs upon the seat of Government, then, as now, a place of few attractions. It lies low and is necessarily unhealthy, especially during the rainy season; but during the year of which I write there had been a phenomenal dearth of sickness. The town consisted mainly of administrative offices, large and comfortable brick structures, a few factories, and two so-called hotels. Of course, the last claimed little affinity, except in name, to kindred establishments on the Thames Embankment or Brussels boulevards. Their doyen was one of the oldest buildings in Boma, and its comfort and elegance may be measured by the fact that travellers enjoying the shelter of its too hospitable roof were frequently compelled to spread rubber blankets over the mosquito bars of their beds in order to avoid a thorough drenching. The rain and mosquitoes and such small pests are, however, quite innocent disadvantages of travel on the Lower Congo. In Boma, and along the route to Leopoldville, rats literally swarm, and are not foes to be despised. Of this an American friend had an unpleasant reminder during his stay at Boma, for one night, when vainly wooing sleep at his hotel, he was so severely bitten that for some time following he was invalided.

Horses and cattle do not thrive along the Lower Congo, for only within the limits of Boma, where the coarse natural grasses have been supplanted by other varieties, can fodder be obtained. The soil of this part of the Congo basin is hard clay, which barely supports a rank grass; the hollows are generally marshy, and the hill-tops often entirely bare. Sometimes, however, the scenery of 
the Crystal Mountains is really grand, and it is hard to realize that its green hills and wooded valleys are a desert to all intents and purposes. Few living things, mosquitoes and rats always excepted, can be descried, for the natives, never very numerous here, have long since deserted their villages and moved away several days' journey. As the eye wanders over hundreds of square miles of territory, not a human habitation can be seen except at rare intervals, and then it is only a temporary village of railway labourers or a station.

When I first went "up country" we derailed at Lufu, although the line was actually complete to Kimpasse, some 37 miles further on. That this extension was not used was the result of a queer labour war. Lufu had been for long the great centre of the

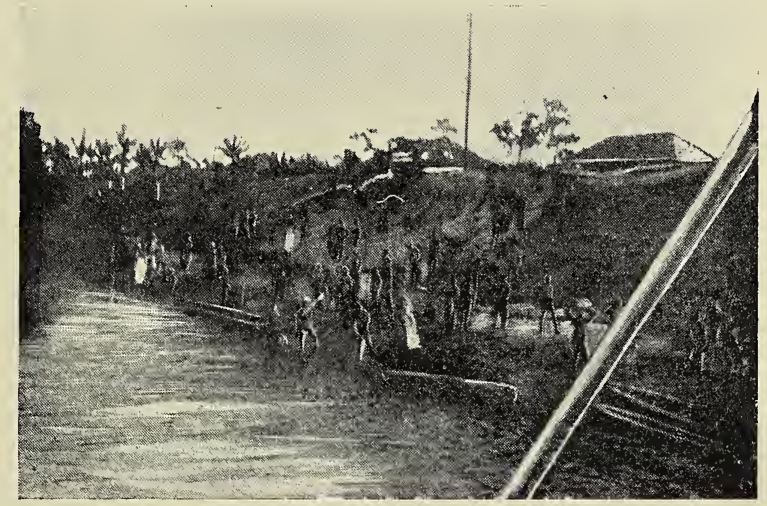

A typical Station ON THE congo.

caravan trade of the Lower Congo, and upon it all caravans from the interior converged. The wily carriers were conservative to the backbone, and, knowing their power and the value of combination, resolutely refused to assemble at Kimpasse. Consequently, if the rail-road shipped goods to that place, the freight either remained there or had to be returned to Lufu. Of course, this impasse only existed a comparatively short time, for, with the advance of the iron horse to Lukungu the direct caravan route was again touched, Lufu was deposed from its former proud pre-eminence, and the opposition of the carriers was broken. From Lufu we marched over the caravan route to Leopoldville, a 
journey of fifteen days, and thence proceeded by river steamers to Stanley Falls, where many of the white men parted, never to meet again or ever more return to civilization.

During the early years of the Congo State all merchandise, etc., was transported to Stanley Pool on the heads of natives. The length of the route and the exhausting character of the march strewed the wayside with the bones of many men, white as well as black, who faced this weary journey of nearly a month's duration. At every step of the road may yet be observed the rude wooden crosses and punctured squares of zinc indicating the last restingplaces of those whom starvation or the deadly climate struck down. Here and there, far from the haunts of men, may be seen a cross, marked simply "Disparu," or giving the name and date of decease. At Lukungu, which was a kind of half-way house, there was, as far back as 1896, a promising cemetery, while at Leopoldville the cimetière is considered one of the principal "sights" of the station, for it boasts of many marble slabs and crosses of stone. It is problematic, however, whether the Bangala crews of the river steamers have left anything under them.

The Matadi-Leopoldville Railway was commenced in the early part of 1890. The company which had undertaken the work was floated with a capital of $£ 1,000,000$, of which $£ 400,000$ was subscribed by the Belgian Government. It was estimated that the construction of the road would be completed in four years, but twice that period and an expenditure of $£ 2,400,000$ were required before the line was opened. In June, 1892, the track extended only eighteen miles into the mountains, one-half the original capital had been expended, and nine hundred labourers had fallen victims to the climate, while many more deserted or had openly revolted. When, however, the line was completed, the company found itself in a position more favourable than had been anticipated by the most sanguine advocate of the enterprise. In the posts of the interior, and especially at Leopoldville, large stocks of rubber and ivory awaited transport, for portage over the caravan route had long been made impossible. At the other terminal, also, much merchandise had been collected pending the moment when the iron horse should begin his work.

The cost of transportation from Matadi to Leopoldville by the old caravan route was estimated at $£ 40$ per ton, and at this price 
the tariff was fixed by the railway company. Exorbitant as this demand was-at the same rate it would cost $£ 480$ to send a ton of potatoes from San Francisco to New York-no resistance was possible. No sooner had the rail reached N'Dobo, on Stanley Pool, than the authorities ceased to impress natives into the carrier service, nor would they permit anyone else to do so, for the Belgian Government was now interested in the railway to the extent of some $£ 1,000,000$, and it was clearly in the interest of the capitalists that the new enterprise should monopolize every ounce of freight. For many months the shareholders were all smiles, for the undertaking had been expected to pay only a moderate interest on the first estimate of cost, and now the rush of business was so great that the administration was enabled to distribute interest on the entire capital invested.

From some points of view, no doubt, this result must be regarded as eminently satisfactory. The "good time," however, cannot last long, and as soon as the supply of rubber diminishesit has already begun to do so in very sensible degree, either through the exhaustion of the rubber-vines or a really sincere repudiation of the system of massacre which alone has induced the natives to "gather" the product-the shareholders will find themselves compelled to rest content if the line merely pays working expenses.

As now organized (except, of course, in the matter of freights), this railway will fully answer all the requirements of trade for many years to come. Should the traffic, however, in the dim and distant future assume large proportions, a considerable distance of the line will have to be reconstructed. Its extremely narrow gauge of $29 \frac{1}{2}$ inches is even now a serious disadvantage in view of the continuous curves, and the grades run up to five feet in the hundred. So dangerous has this proved that no trains run at night, and derailments are very frequent. No attempt is made to run heavy loads, and, indeed, it would be impossible to do so. Three or four loaded trucks is the maximum of which a locomotive is capable up the grades, while passenger trains are made up of one first-class carriage, one second-class car, and a baggage van. Tumba is the half-way station, and here trains going up or down "put up" for the night. Outside Arizona or the Sahara a more dismal place could hardly be found, nor one with worse 
accommodation for travellers. Great is the relief on the following day when Stanley Pool is seen stretching away in the distance, and Leopoldville is sighted close to the first of the series of rapids extending from the Pool to Matadi.

Of my second voyage up the Congo, short indeed compared with that undertaken some three years earlier as an employé of the State, I need write little, for the usual monotonous steaming day after day between verdure-covered islets was varied only by an occasional stop at some miniature post for the purpose of taking on board the half-rotten wood which constitutes the fuel of the Congo river steamers. None of these rests was as pleasant as that at Bolobo, where a neat mission station nestles among

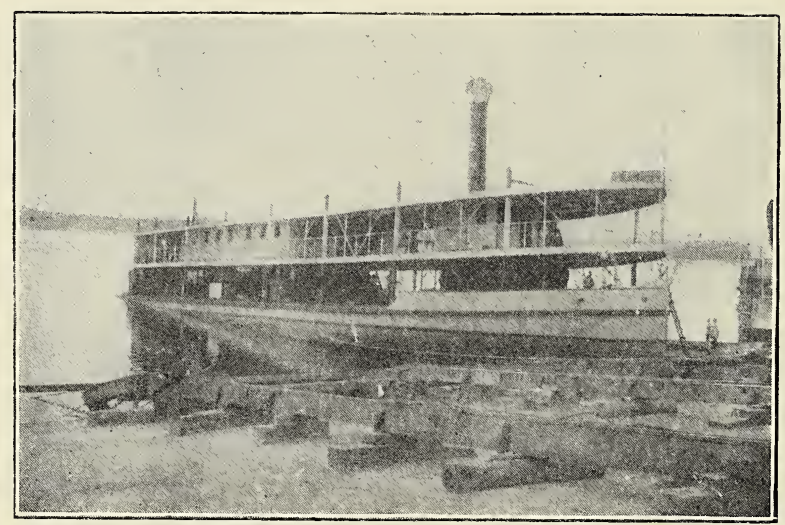

STERN-WHEELER " BRABANT."

shady trees beside the Government post, and a market has been established on the river-bank for the sale of provisions to passing craft.

There are probably over a hundred steamers, large and small, now plying on the waters of the Upper Congo and its tributaries. The majority, of course, belong to the State, for the simple reason that the latter enjoys a monopoly of the transport business. This river marine is manned almost exclusively by Scandinavians, and it is due to these hardy and conscientious workers that so few disasters have attended the opening-up of new and unexplored waterways, until now there is scarcely a navigable stream along which steamers do not pass 
between the different posts and Leopoldville. Here and at Kinchassa, close by, are the shops for putting together the new hulls and machinery sent out from Europe, and here, also all repairs are done, vessels having occasionally been towed a thousand miles down the upper river after having sustained comparatively trivial damage. Here, again, the most efficient employés are Scandinavians, though all work is, of course, performed under the supervision of a Belgian army officer, whose experience and notions about machinery seem to be held in slight esteem by the "old salts."

Nearly all the river steamers are stern-wheelers, and the largest are some 150 tons burden. Quite recently, however, several barges of 300 tons have been added; but these have proved by no means the success that was anticipated, for, as evidenced by several disasters, they are difficult craft to manage in a strong current or heavy wind. They have each a tow-boat of considerable power, but have never demonstrated their superiority over the earlier class of vessel. All the steamers are of very small draught, the largest requiring only five feet of water, and even then they occasionally remain fast on sandbanks. In many of them the vibration caused by the machinery is so great that it is impossible to write or even read while they are in motion.

According to all accounts the Congo Government is inordinately proud of its river marine, and especially of what it is pleased to call an "express postal boat." This vessel has been described as a "really beautiful yacht," and in fact does resemble one of those yachts used by Dutch fisherfolk in pursuit of mackerel in the North Sea. Her cabin is placed below decks, only a thin bulkhead separating it from the boiler-room, and passengers are consequently subjected to a continuous Turkish bath. The deck also, as in all these river boats, is abaft the boilers, useful in this case for furnishing a supply of heat rivalling that given by the sun. An electric-light plant was placed on board to shed the "beams of civilization" over the dark waters of the lake-like river; but as fires are put out at sunset, and day fogs are unknown, it cannot very frequently be used, even when, if ever, it is in working order. A searchlight was installed forward of the foremast to perform some marvellous service, but it has certainly never been able to penetrate the murky waters and discover the ever-abounding snags and 
sandbanks. Finally a machine-gun stands imposingly in the bows, ready to send its hail of death into the jungle whenever there is any ammunition on board for such a purpose. The vessel has twin-screws, and was evidently built for speed; but she usually succeeds in arriving a day later than any of the stern-wheelers, and this in spite of the fact that she carries no cargo or coloured passengers.

The steamers, as a general rule, are as uncomfortable and badly arranged as they well can be. In the larger vessels a supreme effort has been made by the architect to surpass himself, with the result that he has produced superlative discomfort, and demonstrated to the most inexperienced traveller that he has never journeyed in hot countries. The cabins are ill-appointed and dirty, and I may mention, as a characteristic detail of the accommodation provided in the "Hainaut," that the mattress in the berth assigned to me was absolutely sticky with filth. The lower decks of these river steamers are almost invariably tenanted by a malodorous crowd of blacks. This, however, is a minor infliction compared with the cuisine conducted in his own sweet way by a much-tattooed Bangala. I am not more than ordinarily squeamish, but I confess that a sight of the cooking operations invariably deprived me of appetite. Of the table I will refrain from speaking, for it is a painful subject; the steady diet of goat-meat, rice, kwanga and hard biscuits was, to say the least, extremely fatiguing. Throughout this voyage I followed my almost invariable custom, during Congo steamer travel, of sleeping in a chair on deck to avoid insects, bad odours and filth, leaving the cabin to be occupied by my baggage and a Belgian who was suffering from fever.

I have heard and seen much of the callousness of the Chinese, but certainly their indifference to human suffering does not exceed that of the average Congolese Belgian. The sick man lay in a raging fever without one of his countrymen to aid or even notice him; and a Belgian doctor in the employ of the State, who happened to be travelling to the Upper Congo, never troubled to look at, much less attend to him, until I very strongly protested. Then he found that the poor fellow was dying. He hurriedly poured some wine down the patient's throat, but the relief came too late; and so there was a burial next morning at the military camp at Yumbi. This strange indifference I have frequently had 


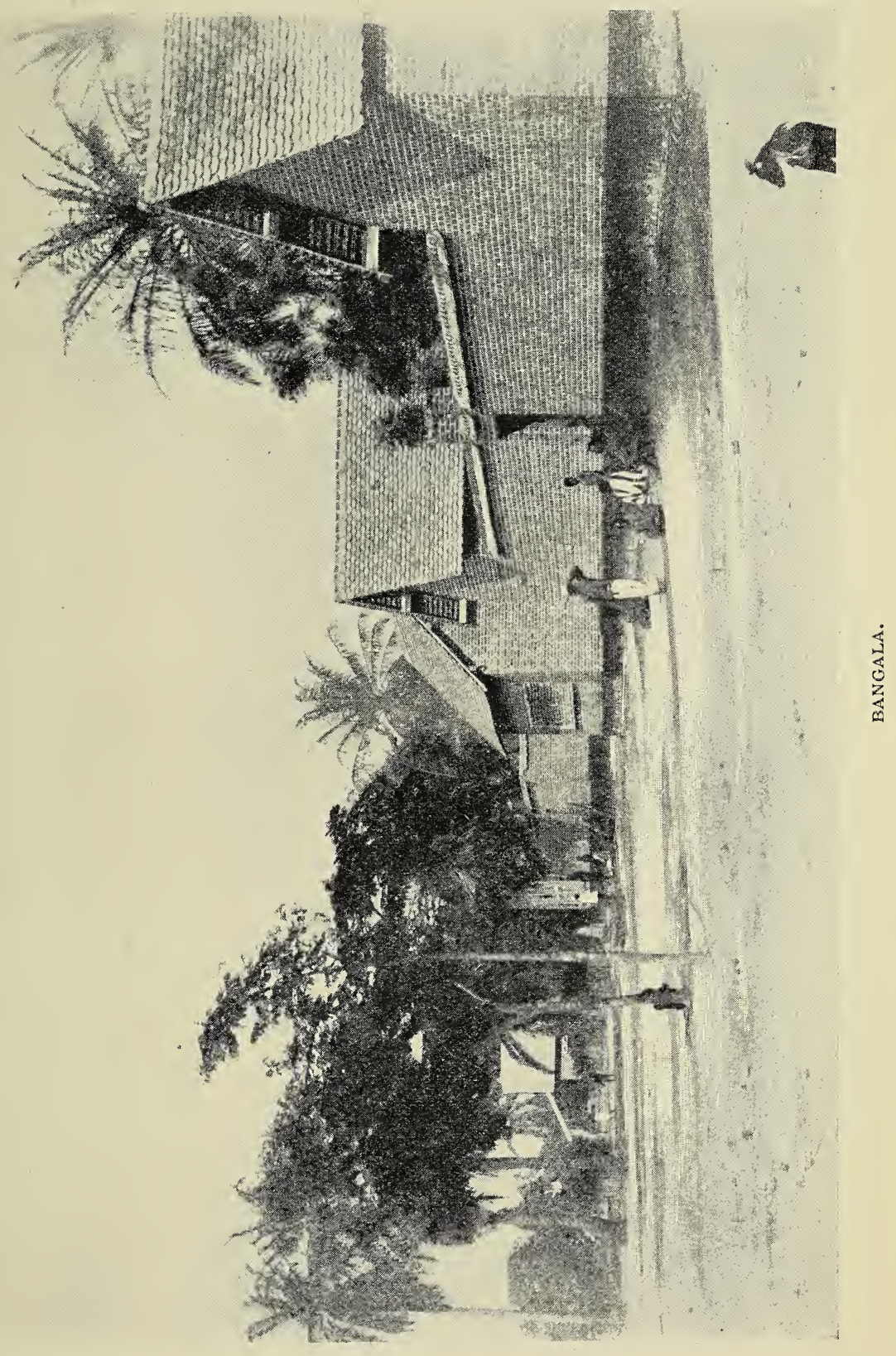


occasion to notice among the traits of the Belgian on the Congo, and it is quite consistent with his too often selfish and cowardly character.

After fifteen days on board the "Hainaut" I reached Mobeka, a station at the mouth of the Mongalla River, and there reported myself to Major Lothaire, the local manager of the Sociéte Anversoise du Commerce au Congo, the great rubber-gathering and trading company to which, as a sequence of three years spent under the flag of the Congo State, I had recently transferred my services. From him I received instructions to proceed to N'Dobo, a post in the eastern part of the company's concession, and at that time the headquarters of civilization in the region of the Budjas, the most fierce and intractable of the Middle Congo tribes, whose near and not too pleasant acquaintance I was to make later on.

The Mongalla concession, I found, included a territory nearly twice the size of Belgium, divided, for administrative purposes, into five "zônes," each of which has its "chef," and from three to six posts, or "trading stations." The chef-de-zône supervises the work of the post-managers, and these in turn control and direct the daily life of the natives. Of the character of this administration, which at that time carried with it the rights of wiping out villages and of indiscriminately killing men, or sending into slavery men, women and children, I very soon had ocular evidence. As to what had happened in the past, I may say that one of the oldest agents in the concession, with whom I spoke on the subject, laughed heartily, or heartlessly, when I suggested that perhaps ten thousand natives had been slaughtered under the company's rule, and declared that double that number would be nearer the mark. Judging from personal observation, and from what the natives themselves have told me, I am inclined to think him right.

The agent who wrings the largest supply of rubber from the people of his district is, of course, the most highly esteemed. It is consequently not surprising that men of low birth and instincts, in their frantic race for commission, have followed the example set by what they have been taught to regard as a perfectly legitimate Government, and taken part in adventures elsewhere considered the prerogative only of properly-constituted 
administrative authority. It is of one of these enterprises, having for its object the coercion of a tribe which had long refused to accept the rubber régime, and finally succeededthanks to its exceptional courage and numbers-in throwing off for a time the yoke of the company, that this narrative will principally treat.

At N'Dobo I was received by the post-manager, who informed me that the chef-de-zone had left orders that I should join him at a place called Yambata, two days' march inland. He, however, advised me that for the present it would be quite impossible for me to proceed, as an escort of at least twenty soldiers would be necessary, and he had but half-a-dozen men

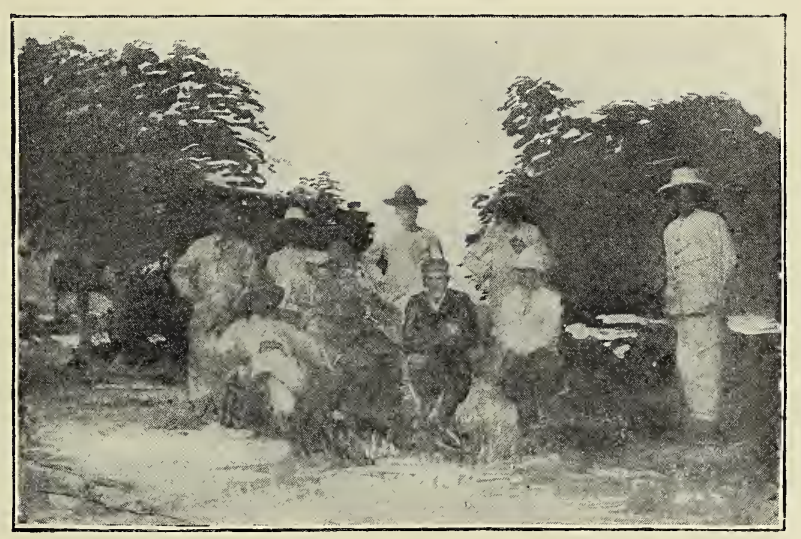

MAJOR LOTHAIRE AND HIS OFFICERS.

at his disposal. It was also, he said, then impracticable to secure the required baggage carriers. Moreover-and this seemed an insuperable difficulty-the small creek by which, in the rainy season, small canoes were enabled to approach within a short distance of Yambata, was dried up, and consequently all transport in the interior was temporarily suspended. I would, therefore, be compelled to wait until he could send to the chef for further instructions and an escort.

I accordingly remained at N'Dobo, which is on the main river, for some weeks, during which I had ample opportunity of witnessing the operation of the system there employed to "gather" the rubber. As the same method, with local variations, prevails 
throughout the Congo State, a brief digression from my story may here be permitted.

There are, or were, in the immediate vicinity of N'Dobo about a dozen villages, the people of which were obliged to bring in rubber every fifteen days. On these occasions the natives crowded into the post, each village in charge of a "capita," or headman, whose most important duty it was to ensure that the demanded amount of rubber was collected. These capitas usually belonged to tribes settled in other districts of the State, and were, as a general rule, armed with muskets of the gas-pipe variety, although some had breech-loaders. They were paid by the company, but the villagers were expected to supply them with food, and this Mr. "Capita" was never remiss in deciding should be of the best and of sufficient quantity.

The natives carried to the muster small baskets supplied by the post, and supposed to be full of rubber. When all had arrived, the people were ranged by the capitas according to their villages. The agent, who had their names inscribed in a book kept for the purpose, then called the people forward, first by villages, then individually. As each man stepped up I noticed that he carried, attached to his neck by a cord, a small disc of metal evidently cut from the zinc lining of a packing-case, and that each disc bore a number corresponding with that entered in the book opposite the man's name. The soldiers having ranged the people in lines, each man with his basket before him, the agent proceeded to verify the individual numbers-not without some difficulty, however, for the natives by some means or other frequently get their "tags" mixed, and much time and a fearful amount of shouting and gesticulation are required, on the part of both natives and white man, to set matters right.

As each man or boy presented his basket, the agent carefully inspected the quantity of rubber it contained, and paid the bearer accordingly in mitakos-pieces of brass wire about six inches long, the estimated value of which at N'Dobo was about a halfpenny. I calculated that the rubber was paid for at the rate of rather less than one penny per pound, which certainly could not be considered excessive in view of the fact that at that time the product in Europe was fetching from two to three shillings a 
pound. Those natives who had brought in quantities which the agent deemed insufficient were ordered to one side, and as soon as the entire village had been thus inspected and paid, these delinquents were seized by some of the "soldiers" attached to the post, thrown upon the ground, and soundly flogged. Some received twenty-five lashes, others fifty, but I have occasionally seen even 100 lashes administered, the instrument used being the "chicotte," a heavy whip of hippopotamus hide. This proceeding-inspection and eventual punishment-was repeated until all the villages had been dealt with. Then the natives started off for their jungle homes, usually at a sharp trot, apparently only too glad to escape with life from a place which no doubt they looked upon much as the

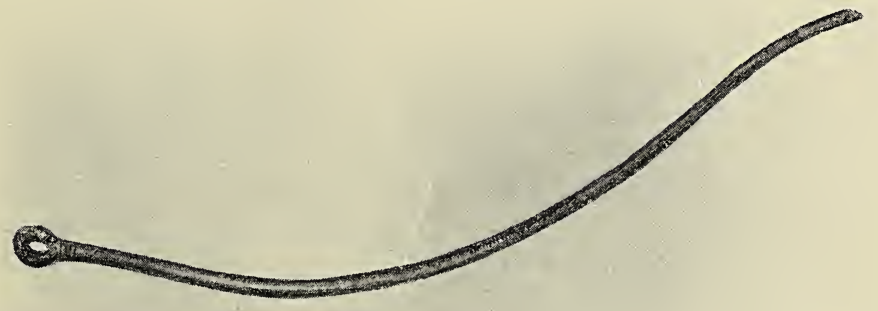

" LA chicotte," made of hippopotanus hide, USED IN FLOGGING THE NATIVES.

Belgians' forefathers regarded the torture-chambers to which they were oftimes led by their Spanish masters. They, of course, carried with them their baskets and their mitakos, which they did not want but were forced to accept. The manager of the post had accumulated perhaps no less than a thousand pounds of rubber at the cost of about $£ 4$ sterling, including presents to the chiefs and capitas. Thus was rubber "gathered" twice each month at N'Dobo.

I found that it was usual to "tag" not all, but only threefourths or so of the male villagers. Those "tagged" at once became mere slaves to the company, for rubber-making occupied 
all their time, the victim having to search far and wide for the giant vines from which the sap is extracted. They were not even fed by their taskmasters, their only remuneration being merchandise or mitakos distributed in ridiculously small quantities, as already described.

The cruel flogging of so many men and boys would probably have had a peculiar effect upon a new-comer, but I was in a measure case-hardened. My experience in the State service during three years had made me familiar with many such, and

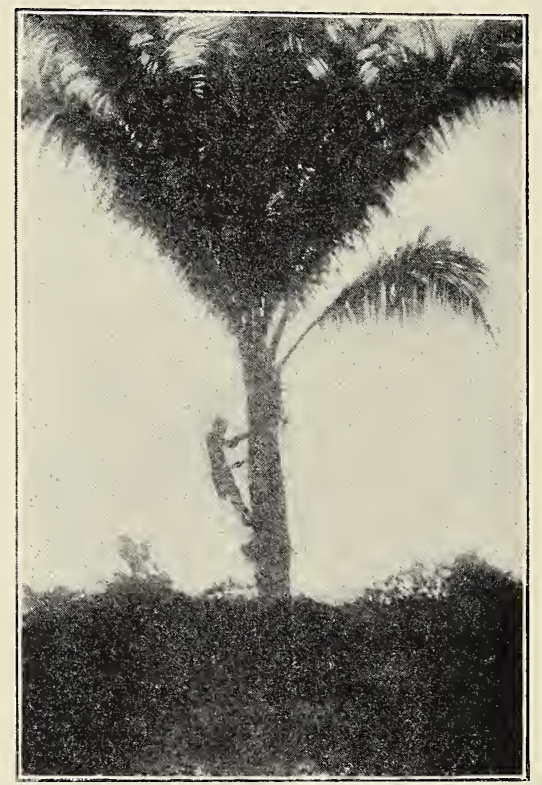

COLLECTING PALM WINE.

worse incidents of Congolese life. For instance, at the Government post where I was for a long time stationed, a man had died as the result of an exceptionally severe castigation at the hands of a white official, and elsewhere I had seen blood drawn from the backs of women.

At N'Dobo I found many brick houses and magazines in course of construction under the direction of an ex-architect and builder. At that time, it was evident, the company's officials at Mobeka entertained keen hopes that the fierce and hitherto intractable Budjas of the interior were about to tumble over each 


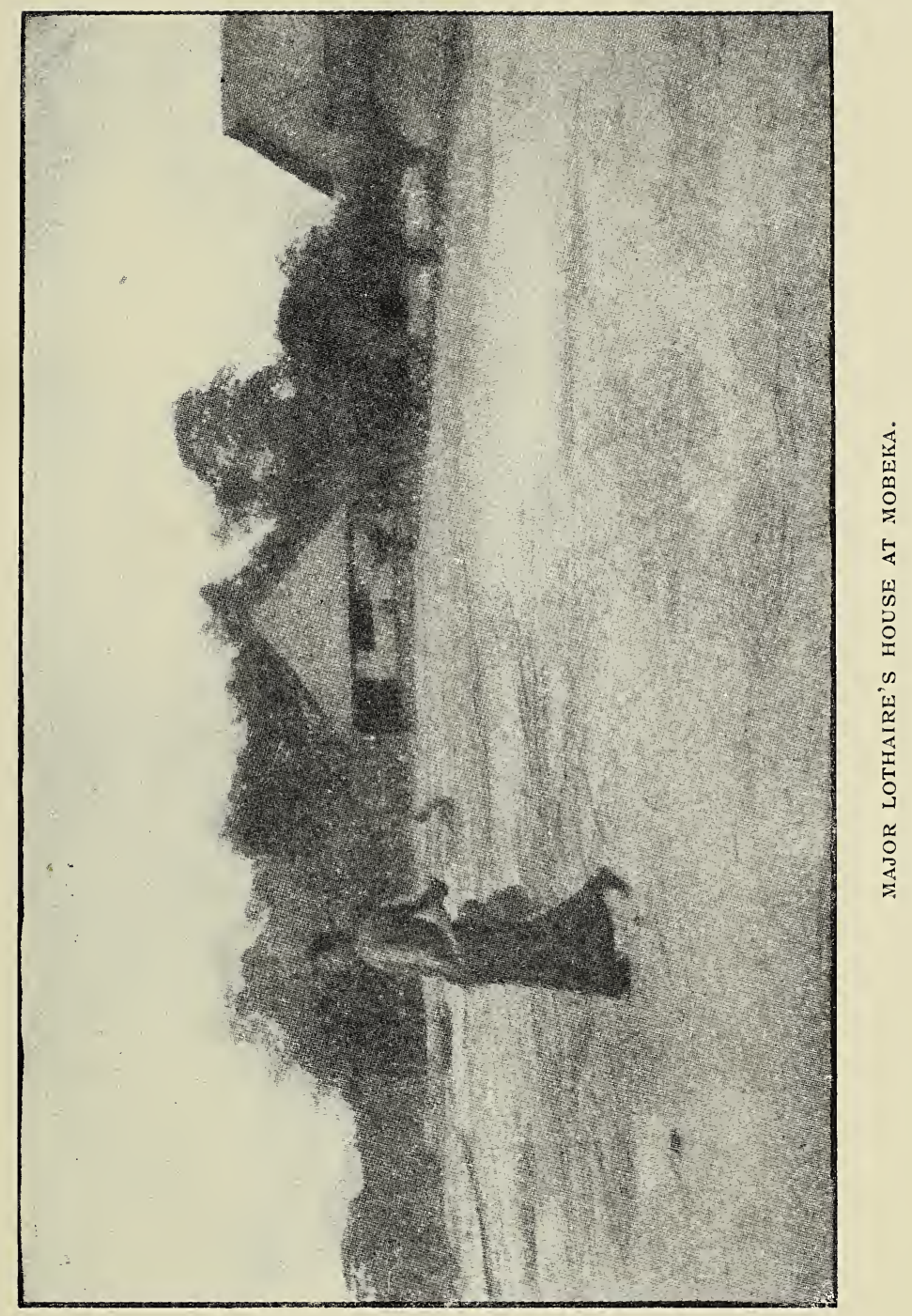


other in their eagerness to bring in rubber-an idea which proved very erroneous, as will later be seen.

The Brazilian rubber-gatherer has no reason to envy the people engaged in a similar occupation in the wilds of Africa, for his work in comparison is a mere picnic. The great rubber-trees of the Amazonian forest yield to him their precious sap after but a few blows of the axe, and fill the bucket of the collector without entailing upon the latter any necessity of raising himself above the ground. Nor does the extraction of a few quarts of sap deprive him of another supply from the same source later on.

Not so, however, with the Congolese rubber-gatherer. In the African jungle the sap is drawn from a giant creeper (often six inches in diameter at the base), which, shooting upward towards the life-giving light of heaven, twists about the surrounding vegetation-its rivals in the struggle for existence. After reaching the crown of the highest monarch of the forest (often a hundred feet above the ground), the vine rises still further until it is bent back by its own weight to the topmost branches of its original support. Then it climbs along these branches, and those probably of half-adozen other great trees, until the machete of the rubber-gatherer cuts short its career.

The Congo native, when about to gather rubber, generally goes with his fellow-villagers far into the jungle. Then, having formed a rough, shelterless camp, he begins his search for the creepers. Having found one of sufficient size, he cuts with his knife a number of incisions in the bark, and, hanging a small earthenware pot below the vine, allows the sap to slowly trickle into it. Should the creeper have been already tapped, the man must climb into the supporting tree at more or less personal risk and make an incision in the vine high above the ground where the sap has not been exhausted; and here he will remain, perhaps the whole of the day, until the flow has ceased. Not unfrequently the natives slumber on their lofty perches, and, falling to the ground, become victims to the white man's greed. Few Africans will imperil their lives in rubber-gathering unless under compulsion. The natives, if pressed for time, as they usually are in the Congo in consequence of the threats of the white man and the fear of the Albinis of the soldiers and the muskets of the capitas, cut down 
long lengths of the giant creepers and then subdivide them to make the sap ooze out more quickly.

Of late, the people have been compelled to so frequently tap the vines that the latter soon dry up and die. Each tribe has only a limited extent of forest which it can call its exclusive domain, and it consequently very frequently happens, when their own "bush" is worked out, that natives from one village penetrate the territory of the other in defiance of tribal usage. Such an invasion is naturally resented by their neighbours, who, equally pressed no doubt by circumstances and the white man, are themselves experiencing difficulty in making up the quota of rubber definitely fixed for each village, and a deficient production of which may entail dire punishment and even death. In consequence, disputes arise between villages which heretofore, perhaps for quite a long period, have been at peace; and then come wars, involving more or less loss of life, destruction and cannibalism. Natives, I may add, have often come to me with bitter laments over the disappearance of their brothers after accidents when rubber-gathering, or the attacks of leopards or hostile tribesmen.

The coagulation of the sap is effected in a variety of ways. In some regions, the natives smear the latex over their chests, and with their hands rub it until a small ball is formed. This process is repeated until the ball is the size of a small walnut. These balls have often a reddish hue, the result of the powdered camwood with which the natives usually smear their bodies. In other parts, the juice is poured into a pot in which is boiling water, and is then allowed to boil until all the water has evaporated and the rubber forms a kind of cake over the bottom of the pot. This product, when brought to the stations, is cut into fine strips and hung upon battens in a drying-shed for several months. In the Province Orientale the natives generally pour the sap into an oblong form of box, made of flat-sided sticks laid upon the ground. The heat of the sun is utilized to coagulate the sap, a thin layer of latex being poured on the top from time to time until the whole forms a solid mass of rubber some fifteen to twenty inches long, eight inches wide, two or three inches thick, and weighing from eight to ten pounds. After reaching the stations, these slabs are cut into small strips 
or vidoles (fingers), and then placed in sheds to dry upon shelves made of poles.

I have seen it stated in official documents, and in books written by persons represented to have travelled through the African forests, that there are regions where the jungle is literally a tangled mass of rubber-vines. Such stories are ridiculous, for nowhere does the creeper exist in such luxuriance; like all tropical jungle vegetation, it is scattered over large areas with many other similar plants, which may belong to the same genus but are not the true rubber-vine. On an acre of jungle one rarely finds two trees of a kind, and the same may be said of the large creepers, or lianas, with which the tropical bush abounds.

That the stock of rubber-vines in those parts of the Congo which have been worked for any length of time is being rapidly exhausted is evidenced by the ever-increasing difficulty experienced in inducing the natives to exploit it. Wherever I have been in this vast territory, always excepting, of course, the Budja country, which has never been much worked, the natives bitterly bemoaned the scarcity of the rubber-producing lianas, and piteously begged to be allowed to perform other service than rubber-gathering. In some places they brought in large quantities of "false rubber," a resinous matter much resembling caoutchouc, from which, indeed, when freshly-made, it cannot be easily distinguished. In the course of drying, however, the false rubber assumes a glossy appearance, unlike that of the genuine article. 


\section{CHAPTER VI.}

\section{THE REVOLT OF THE BUDJAS.}

A "Noble White Man"-The Congo at N'Dobo-Bad News from the Interior-The Troops for "The Front"-Major Lothaire's Arrival-The Massacre at BauOur March against the "Man-Eaters"-The Budjas and their CountryMaking a Stockade-A Night in the Forest-An Exhausting March.

My enforced stay at N'Dobo proved tolerably pleasant, if sojourn in any part of the Congo State can be so termed. Those days passed quietly and quickly when the manager failed to indulge in his penchant for excessive quantities of alcohol. On other and frequent occasions, however, the place assumed a very different aspect. Matters became a howling comedy; the manager howled and the natives howled in mockery, and night as well as day were made hideous by uncouth whoops and yells. At such times I systematically retired to the seclusion of my room, from which I could hear, but not see, the fun. There were sounds of the manager falling upon the gravel walk and of oaths in Flemish, Walloon, French and German, mingled with the loud laughter and apparently witty comments of a crowd of naked savages, gathered around to witness the antics of the noble white man. I often thought on such occasions of calling upon the "gallery" to give the agent a refreshing dip in the murky waters of the great river, but, upon consideration, decided that this might prove too severe a shock to a system already weakened by excesses and, moreover, not overaccustomed to the luxury of a bath.

Although our diet at this station was limited to such things as could be procured from the natives, and they were indeed few, we managed fairly well, for we had a constant supply of a kind of fish which was very palatable. The river population are occupied with their fishing traps and nets from morning till night, and many fine "samaki" we had through their industry. These river-folk, who 
as a rule belong to the Bapoto race, do not, like the interior people, cultivate plantations, but depend upon the product of their fisheries and the manufacture by their women of earthen pots. They barter these with the interior people for cassava root and other vegetable food.

At N'Dobo the width of the Congo is estimated at twenty miles. A large canoe, carrying twenty to thirty paddles, requires four hours to cross from one side to the other. As a canoe can easily make eight miles an hour, the above estimate-after allowing for time lost in detours to avoid islands, of which there are scores always

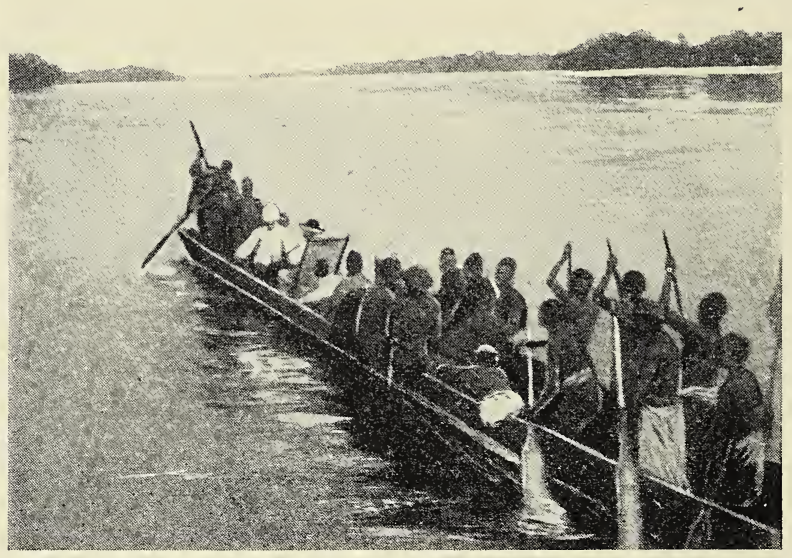

CANOE TRAVELLING.

in sight-cannot be wide of the mark. The depth nearly everywhere is from ten to fifteen feet, although sandbanks are numerous. The islands, which vary in length from a few yards to many miles, provide an excellent refuge for the riverain population in troubled times, and I have more than once seen a whole village pack its belongings into a flotilla of canoes and make for the islands, all within the space of a few minutes. When away from the riverbank they are comparatively safe from the attacks of their jungle enemies and also of the soldiers of "Bula Matari." This phrase, 
in the Fiote language of the "Region of the Cataracts," between Stanley Pool and Matadi, signifies "breaker of stones," and was originally applied to Sir H. M. Stanley on account of the fame he achieved as a maker of roads. Now, however, it is accepted throughout the State as meaning "Governor-General" or "Government."

Several weeks passed without news from the interior. Then rumours of a disquieting character began to pour in, for the natives generally receive advice of what is passing at a distance more quickly than the white man. The chief of a neighbouring village informed us that a courier escorted by ten soldiers had been massacred by the Budjas close to the post of Yambata, and

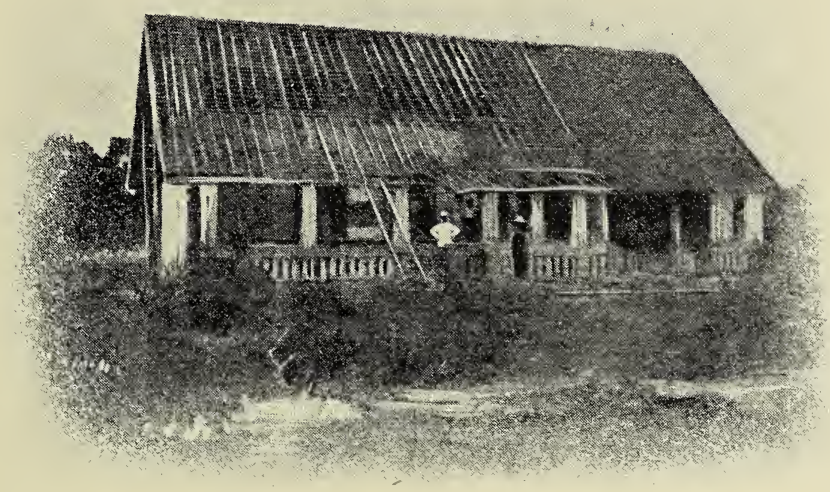

HOUSE-BUILDING, BUMBA.

soon afterwards three men who had been sent forward with letters for the chef returned with a very circumstantial story of having been unable to reach their destination in consequence of the hostility of the natives. Then, a few days later, came official news, brought by a Bangala carrying letters from Yambata. The chef sent strict orders that until further command no one was to attempt the journey to that place; but at the same time he directed me to collect labour and cut a road through the jungle to Yambata "in a straight line and thirty feet wide." It was an easy matter, no doubt, to issue commands of this kind, but to execute them was quite another story, for no labour was available for the 
purpose, and there being no map in the station I could only guess at the general direction. However, I sought to make the best of the situation. I gathered a few natives, began surveying the route with the aid of a pocket compass, and had just commenced active operations when a runner appeared with startling intelligence.

This was nothing more nor less than that the Budjas had "revolted" and that M. le Chef, soon after leaving Yambata on his way down, had been attacked by an overwhelming force, but had escaped into the jungle with a spear wound in the back and the loss of thirty men out of an escort of forty, and a number of carriers, women and boys. Needless to say, this news provided us with ample food for reflection and, what is often much needed in mid-Africa, an acceptable topic of conversation, for the Budjas are the most powerful and courageous of the Middle Congo tribes, and had repeatedly sent white men and their bands of soldiers to the happy hunting-grounds by cooking-pot route. Even the Arabs, who had conquered every other tribe from Zanzibar to the Lower Congo, had in days of yore been driven back with loss by these redoubtable "man-eaters." Some time previously the State had established a "police post" at Mandika, a day's march north of Yambata, nominally for the purpose of "maintaining order," but in reality to aid the Mongalla Company in coercing the natives to gather rubber, which is, indeed, the raison d'être of the Force Publique, or army of the Congo. It now appeared that this Mandika garrison, consisting of an officer and a hundred men, was included in the force blockaded at Yambata, and this emphasised our conclusion that matters would soon become decidedly interesting.

The runner also brought letters for the commandant of the military camp at Umangi, urgently demanding immediate aid, for the principal Budja chief of the Yambata district, Manjumba by name, had threatened to eat all the white men and their soldiers, a prospect which they very evidently did not much relish.

We had not long to wait for the next move. In a few days the commandant of Umangi himself arrived, accompanied by a lieutenant, a non-commissioned officer and two hundred "soldiers."

With my first inspection of the soldiers vanished any expectation that the revolt would be speedily crushed. Many of them were mere boys, scarcely able to carry the heavy Albini rifles with 
which they were armed, to say nothing of the ammunition. I could see from their tattoo marks that few of them belonged to the fighting races of the Congo; on the contrary, that most of them were miserable slaves who had been sold to the State by their masters, or forced from the chiefs by Government officials. Scarcely any of them had been more than a year under instruction, and none had seen active service.

This force was to march at once to the relief of Yambata, and, being not a little weary of an inactive life at N'Dobo and the drunken antics of its manager, I asked permission to volunteer. This, however, was refused, the commandant evidently fearing to diminish la gloire which his protégé, the lieutenant, was to achieve in an expedition of such importance and danger.

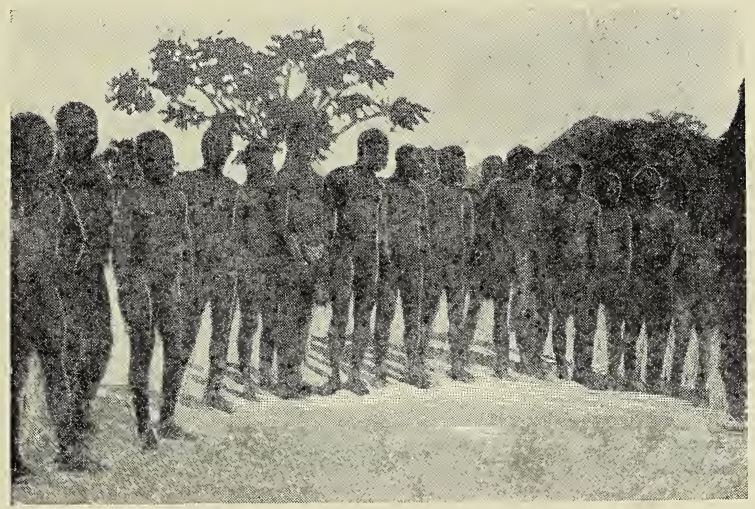

NEW RECRUITS.

I was, therefore, compelled to remain and watch the somewhat imposing departure. The lieutenant had received most carefullyworded instructions, and the soldiers were drawn up and addressed by the commandant, who urged them to let the Budjas see that the soldiers of Bula Matari were strong. This they were certainly not, for many of the poor wretches were already quaking with fear. However, after being put through several evolutions, no doubt with a view to inspirit them, they started for the interior, whence few were destined ever to return.

Within a few days we received news of the safe arrival of the force at Yambata, and of the relief of the garrison. A stirring description was also given of two attacks upon the 
expedition by large bodies of Budjas, which, of course, were gallantly repulsed. The charges of the enemy were described as like the passage of a tornado, but we learned later, and, indeed, suspected at the time, that these attacks existed only in the imagination of the brave lieutenant, the force never having seen a Budja during its two days' march. However, the lieutenant, like many another Belgian officer similarly circumstanced, obtained great credit for his wonderful exploit. In the Congo State there is no surer passport to fame and, promotion than the receipt by the authorities of exaggerated even completely false, accounts of victories over recalcitrant natives. To furnish these whenever possible is a method

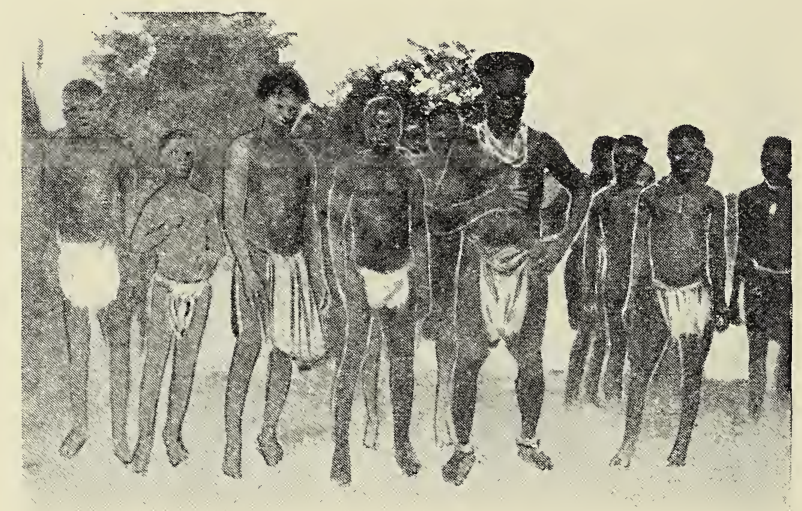

TOPOKÉ TRIBESMEN.

much in vogue among the vainglorious Belgian officers of the Force Publique.

The "news from the front" had scarcely been digested when the company's small steamer arrived, having on board "Major" Lothaire, a Belgian commandant, and fifty men, who were, it was announced, to immediately join the force assembled at Yambata. I also received orders, which came as a great relief, to prepare for departure in two days. Baggage was limited to a small box and the necessary blankets, as there was a scarcity of carriers and it was not thought desirable to have too large a mob of camp followers.

Before my departure from N'Dobo I had an opportunity of witnessing an example of the treatment meted out to the 


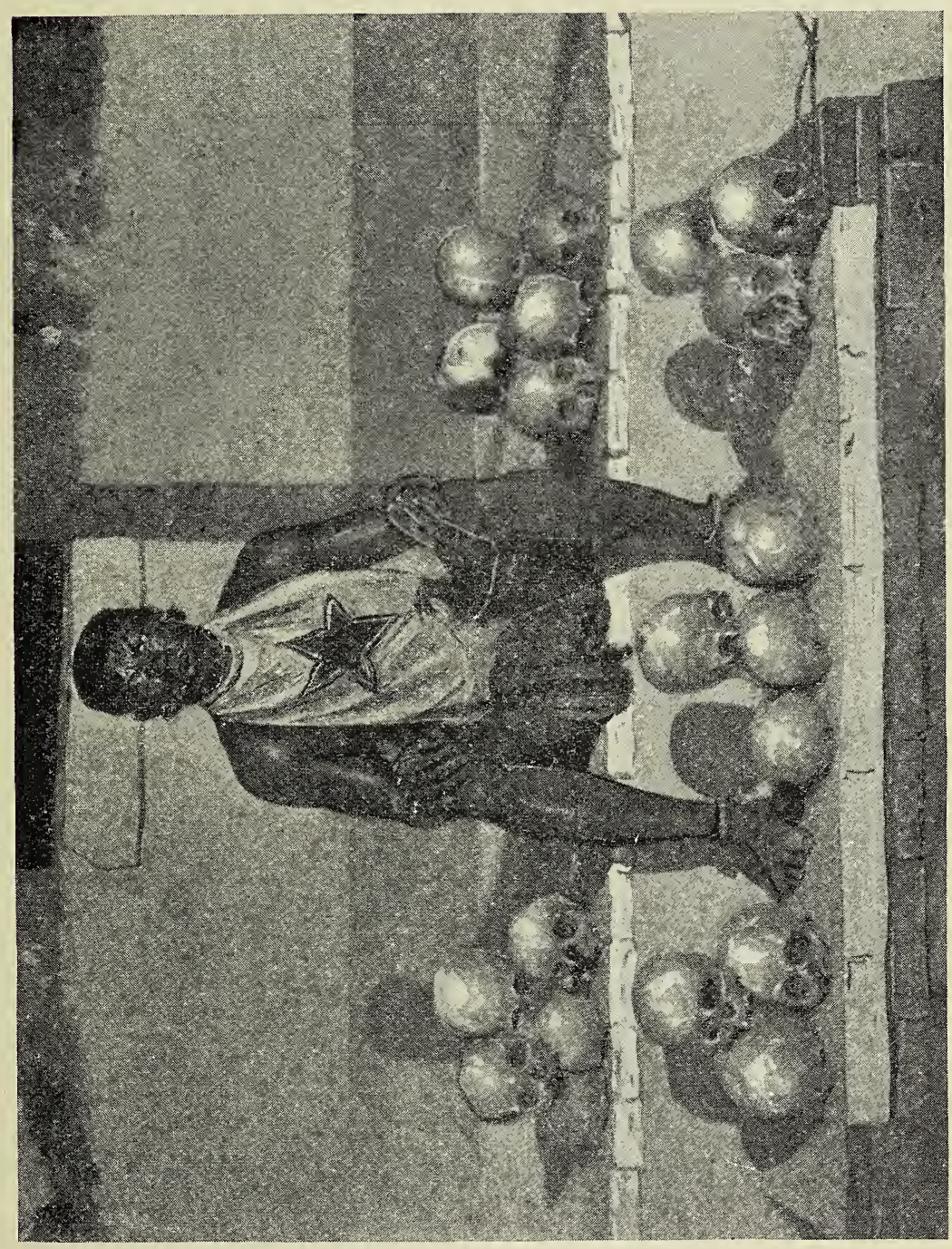

 
natives by "Major" Lothaire. Later investigations showed that the proceedings in question were by no means exceptional, but rather typical, of his emphatically autocratic rule. Many are the stories told in various parts of the State, and especially in the Mongalla region, of the short shrift accorded by "Lopembe" to those whom he has been pleased to consider offenders. Of his reputation and its consequences I shall, however, have another occasion to make mention.

An hour's march inland from N'Dobo was the village of a petty chief named Bau, whose people were compelled to render a variety of services (corvées) usual throughout the State in the case of places which have the misfortune to be situate near the posts. These obligations are so repugnant to the people that they have to be very frequently exacted at the muzzles of the Albinis, which the white men take very good care shall always be in evidence. Though Bau's village contained fewer than a hundred male adults it was obliged to furnish, in addition to rubber, poles and thatch and other building material, labour for the post, and carriers for the transport service to the interior. The women, moreover, were compelled to bring food for sale at the market established at the station. I have, however, usually noticed that most of the produce provided by the women under these circumstances is stolen, before the unfortunate owners have opportunity to more advantageously dispose of it, by the mob of soldiers and other black parasites who inhabit the stations. All these services are regarded as "impositions," and are, of course, practically uncompensated.

Bau and his people, perpetually harrassed by the white man and his satellites, and consequently unable to attend to their own plantations, were brought to the verge of starvation, and finally defied their taskmasters. "They could not do everything," they said, "but were always willing to furnish building material."

When "Lopembe," who was regarded by the natives as the great chief of the white men, arrived upon the scene, the Bangala capita stationed in the village came forward with bitter complaint of Bau's rebellious spirit. That same night, just after dusk, a band of soldiers slipped out of the station and, creeping through a circuitous jungle path, fell upon the sleeping villagers, shooting 
down a score of men, women and children, while the rest fled, terror-stricken, to the bush.

Two hours after the departure of the soldiers the capita who had lodged the complaint and had followed the band of cut-throats, rushed into the station, trembling with excitement, and announced that his wife was among the killed. He was, however, only laughed at, and called a fool for not having sent the woman away. Some time later I heard that Bau had again been attacked by the soldiers of the State, and that on this occasion the old chief had been killed, together with a number of his people.

Finally we set out with the fifty soldiers who had come from Mobeka, and some thirty carriers, who transported our little pile of baggage and still more meagre store of provisions.

The first few hours took us over a fairly good path which had been cleared of weeds and grass. Then we passed many abandoned villages, and finally came to one that was inhabited, stockaded, and surrounded by a trench eight feet deep and ten feet wide. The men of the village ranged themselves along the roadside and presented kwanga, a kind of dough made of the cassava root, to which the soldiers liberally helped themselves. I noticed that all these people wore the zinc discs which denoted that they were rubber-gatherers, and also on this occasion served as passports, for without them the people would scarcely have dared to remain quietly in the village while the soldiers were there. As it was, neither they nor their houses were molested, and after a hasty meal we continued our route.

As we proceeded, the clearings became less frequent and all signs of habitation disappeared, save an occasional trench such as we had seen at the village, but now overgrown with great trees. We had entered the broad belt of forest which separates the Budjas from the people known as Gombés, who inhabit the strip of country between the Budja country and the river.

It is now desirable that the reader should be made acquainted with some details concerning those redoubtable tribesmen, who play such a conspicuous part in the present narrative.

The Budjas may be said to occupy the entire territory bounded by an imaginary line drawn northward from the post Lisala on the main river, to the small river known as the Eau Noire, following 
this stream in an easterly direction almost to its source, and immediately north of the State post Bumba, and thence drawn south to the river at the latter point. Of Budjas there are three sub-tribes. The northern branch, known as the Budja Elwa, inhabits the country along the Eau Noire; to the south of them are the Madjambuli, whom we were about to visit; while to the west, in a direct line extending from Baiengi to the Eau Noire,

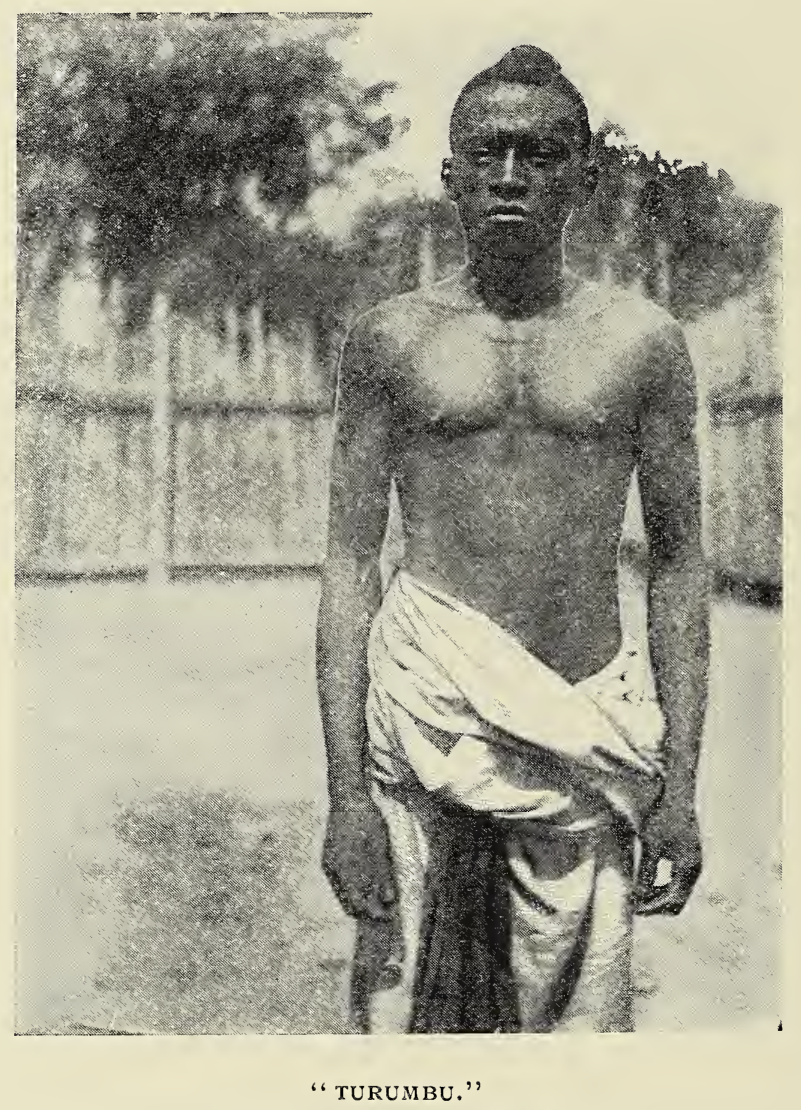

due north, are the Budja Boli. All three divisions, it may be noted, speak the same language.

The origin of these people is difficult to determine, but there is every likelihood that at a comparatively recent time they came from the north, probably from the banks of the Uelle. Their tattoo marks are horizontal lines across the forehead, generally 
three in number. The people are tall for Central African negroes, and have a wilder and more ferocious aspect than I have seen among other Congolese savages. They are known to be exceedingly fond of human flesh, and the number of slaves annually killed among them for food must be very large. Up to the present, because of their notorious strength and courage, the

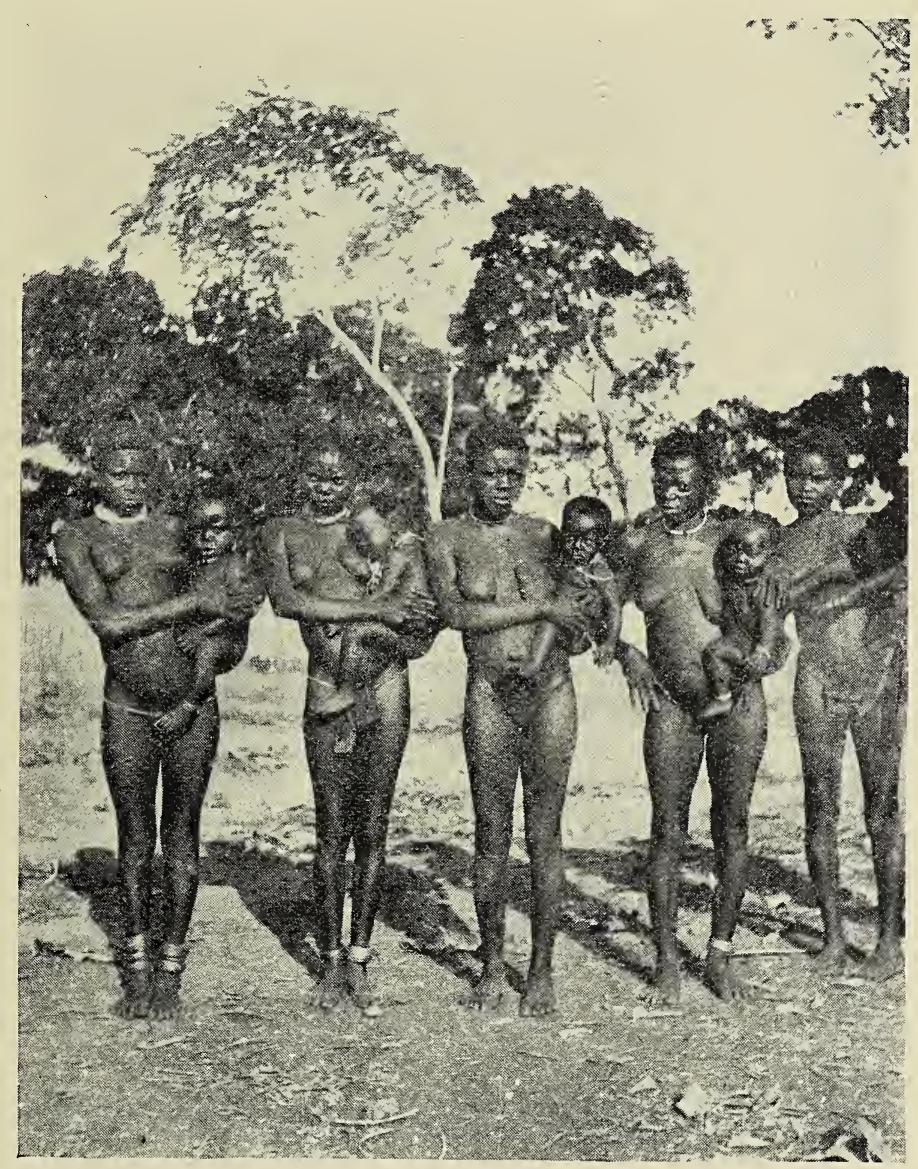

NATIVE WOMEN AND CHILDREN.

Budjas had been left in comparative quiet by the Belgians, who have, as a rule, preferred to wage war upon the weaker and more docile of the tribes. Avarice, however, now proved more potent than discretion. The Mongalla Company was prompted to a serious effort to introduce among them the "rubber régime," it 
being estimated that the large Budja population and extensive forests could not fail to produce great quantities of the muchcoveted and valuable product.

Accordingly, several stations had been already established in the country. Some of the Budja Elwa had submitted to the company about a year earlier in consequence of defeats inflicted upon them by an expedition under Major Lothaire, in which hordes of spearmen from the Eau Blanche and Mongalla River were employed. Eseko, their principal chief, was, however, never captured. It is said that during this campaign many natives from the Itimbiri River came over to the scene of the fighting in order to feast upon the bodies of the slain, and of course the spearmen, and even the "regulars," lacked not meat. A portion of the Budja Elwa having commenced to produce rubber, it was thought that the Madjambuli would follow suit, as their kinsmen, the Budja Boli, had already done. Some of the Madjambuli, indeed, had evinced a disposition to temporize; but when the leaders saw that the white men were putting up post after post, and "tagging" right and left, they decided to resist: and the attack upon the chef of our district was a first blow struck for freedom and man-meat. For the first, perhaps, the Budjas had no very idealistic preference, but the hope of procuring the latter has always been with them a powerful incentive to war. Moreover, they had not yet been imbued with a sufficiency of respect for the breech-loader of the white man as handled by his ragamuffin "soldiers."

We camped about noon, having marched some six hours, ample in the climate and through such thick jungle. The path, indeed, was little better than an animal trail, full of roots and crossed at almost every step by creepers, which tripped up the "tenderfoot" white man, and compelled him to perform a species of jungle calisthenics very fatiguing to the back. Moreover, we had marched for the first hour or so through native clearings, where the trunks of large trees lay by hundreds across our path. Over these we had to climb, the trail seeming to lead to the top of every high ant-hill within range. The carriers had an especially hard time, for many of them were chained together by the neck, being prisoners of the company for reasons which no one seemed to know. They carried our boxes slung on poles, and when one 


\section{The Curse of Central Zftrica.}

fell he usually brought down all his companions on the same chain. Many of the poor wretches became so exhausted by this kind of marching that they could be urged forward only by blows from the butt-ends of the rifles. Some had their shoulders so chafed by the poles that they literally shrieked with pain.

All this had somewhat delayed us, and the entire expedition was much relieved when the order to camp was given. As soon as the column, which had lengthened out to nearly a mile, had closed up, the soldiers were formed in a circle, with rifles still in hand as a precautionary measure in case any band of Budjas had come to meet us, while the carriers were sent out into the surrounding jungle to cut stout poles. These, when gathered, were stuck in the ground by the soldiers and bound together with small creepers

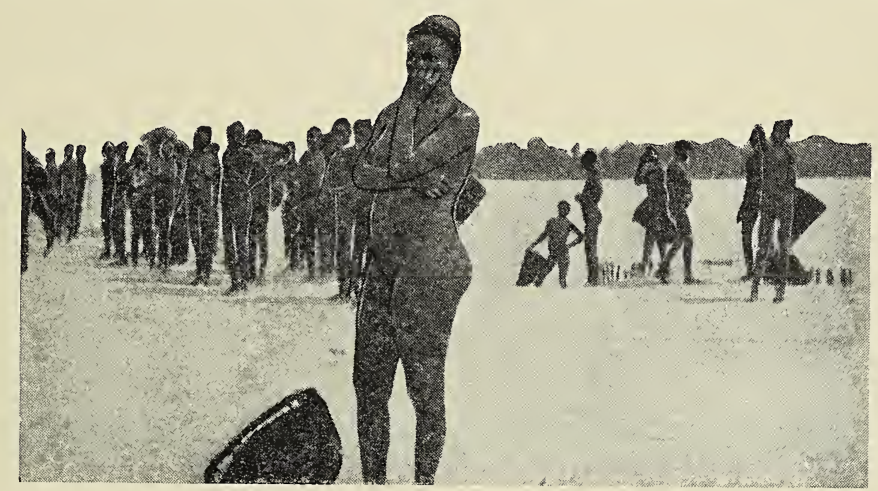

CARRIERS AWAITING ORDERS.

and strips of bark. In a short time, therefore, we had ready a circular stockade some twenty yards in diameter. Around the interior of this the soldiers and carriers arranged rough shelters of poles and leaves, under which they were to lie, with rifles at hand, prepared to repulse any attack which might be made during the night. A slight shelter for the white men was also thrown up in the centre of the zareba, the beds being constructed of poles. I did not venture to occupy one of these couches, for I had had experience of their comfort, but slept that night, as I had done often when exploring new lands, in my deck chair.

As soon as the stockade. had been constructed, the cook began to prepare our meal, a party having in the meantime been told off to bring water from a deserted village close at hand. The 
Europeans, after a wash and a change of clothing, felt much refreshed, but it was well on into the afternoon before we obtained our somewhat meagre repast.

In that gloomy forest it became dark at sundown, and as soon as the sentries had been posted all others went to sleep, with the exception of myself. I lay long awake listening to the peculiar night noises of the jungle. The loud, rasping cry of a wild cat sounded particularly awe-inspiring in the Cimmerian darkness, while insects and night birds kept up a constant din. I made several rounds of the sentries and, strange to say, did not succeed in finding any of them asleep. Finally I also slumbered, until I was-awakened at break of day by my boy, who brought a cup of what purported to be coffee, but which more closely resembled a compound of powdered charcoal and water.

We were soon again on the march, the same order being preserved as on the previous day, I and another company's agent bringing up the rear, while the carriers occupied the centre of the column. For hours we marched over what appeared to be a perfectly level sandy plain covered with giant forest, the foliage of which fortunately kept from us the fierce rays of the sun. But for this we should have soon become exhausted, for we were traversing a region destitute of water, and had only carried a bottleful apiece. These vessels, however, were soon emptied, for, although the greater part of the route was shaded, even gloomy, the air was sultry, and the rapidity with which we marched caused all the white men, and not a few of the blacks also, to perspire freely, inducing an unquenchable thirst. I felt my tongue grow parched, and I was ready to pay any price for a cup of water. At length, when it appeared almost impossible to continue longer without liquid relief, I espied, to my great joy, a carrier who had lagged behind, bearing upon his back a basket in which were several large and ripe pineapples. My companion and I pounced upon him and appropriated one of the pines, which was very quickly divided. I think that no fruit ever tasted more delicious than this, which came so opportunely to quench our thirst, although under other circumstances I confess to having despised the Congolese pineapple as absolutely without flavour.

Greatly refreshed, we pushed forward for two hours longer, when we caught up to the head of the column and halted upon the 
bank of a small stream, called the Koi, where the Major had decided to camp. The zareba having been constructed, a bath in the creek revived us after our long and exhausting march, and we sat down with excellent appetites to a meal of goat-meat and boiled yams.

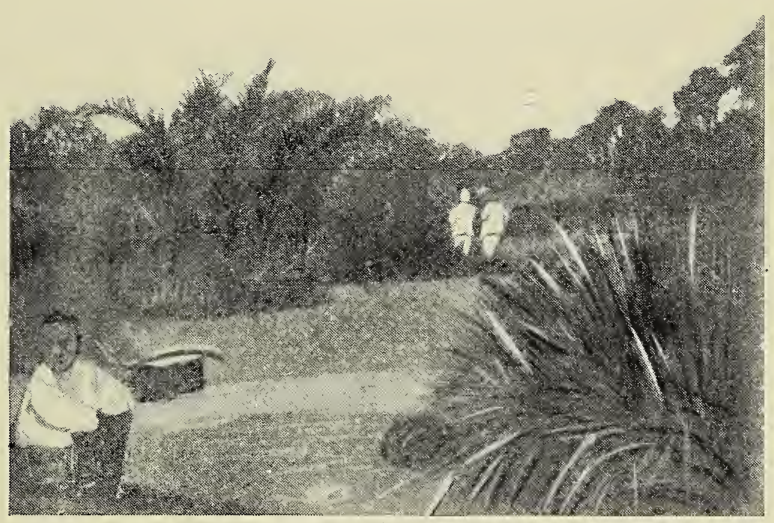




\section{CHAPTER VII.}

THE MARCH TO YAMBATA.

Precautions Against Attack-Budja Villages-The Dawn of "Civilization"-Budja Ambuscades-"Kitchwa na Askari"-Arrival at Yambata-Description of the Post-Playing Tribe Against Tribe-The Belgians as Colonisers-Some Traits of the Belgo-Congolese-My New Command.

As the column was now within three hours' march of the first of the Madjumbuli villages, it behoved us to take extra precautions against attack. A palisade was accordingly erected considerably stronger than that of the previous night, and the sentries were doubled. In the path the sentinels lighted small fires and then withdrew into the jungle a short distance, yet near enough for each man to secure a good view of the fire of which he was in charge. This was done because, more frequently than not, men seated at a fire will either fall soundly asleep or doze, and also because hostile natives will sometimes sneak up in the darkness undetected and spear a sentry. To prevent this, and, as a consequence, entrap any tribesman, more bold than his fellows, who ventures to slink, panther-like, upon the sentinel, a $\log$ of wood with a blanket thrown over it is sometimes laid on the near side of the fire, giving the appearance of a man quietly sleeping on the path. The sentry, however, concealed in the thick undergrowth, is, or should be, closely watching his fire, and has ample time to take careful aim as the enemy raises his spear to transfix the supposed sleeper and simultaneously exposes his naked body to the faint fire-glow.

On the night in question no such event occurred to disturb our well-earned slumbers. The next morning, at daybreak, we resumed our forward movement. Scouts were sent out ahead, the column halted frequently to permit the rear to come up, and every 
reasonable precaution was taken against a surprise, although at any time an enemy might easily have cut through the column marching in single file. In the course of a few hours we emerged from the forest into some extensive clearings, and recognised that we were now in close proximity to the first of a long line of Madjambuli villages. After scrambling for some time through bush-grown plantations we came upon the first of the huts, and here the column was formed in hollow square, with the carriers in the centre.

Budja settlements do not greatly differ from the generality of African villages. The chief peculiarity about them is that they often extend for many miles in the same general direction, being divided one from the other only by short spaces of abandoned plantation or swamp. A single row of huts lines each side of the path, while in the rear a dense growth of bush comes to within a few feet of the buildings. More wretched and unattractive villages I have never seen. No evidence of cultivation is apparent in their vicinity except, perhaps, occasionally some old, abandoned plantations, now overgrown with rank vegetation and more difficult to traverse than the jungle itself.

The huts, only large enough to crawl into, are usually constructed upon a raised platform of clay, with clay walls and a roof of leaves. They are built close together, forming a fairly regular oval, the entrance at each end being narrow, which enables the inhabitants, in case of attack, to more easily prevent the entrance of an enemy. The interiors of these ovals are generally kept very clean, for here in the evenings the people squat before their fires. A march along a line of Budja villages simply means passing from one oval to another. The huts themselves are seldom more than eight or ten feet in length, oblong in shape, with walls rising three or four feet above the platform. A crude design in charcoal and red and white clays is the only indication of artistic instinct among these people. A small hole closed with a strip of bark at night gives access to the interior, which is smoke-begrimed and malodorous. In each village there is usually an open shed of somewhat larger dimensions, in which, on rainy days, these lords of the jungle meet, presumably to discuss local politics.

It was through lines of such villages that we were now to march. Here no great trees dispensed shade to shield us from the 


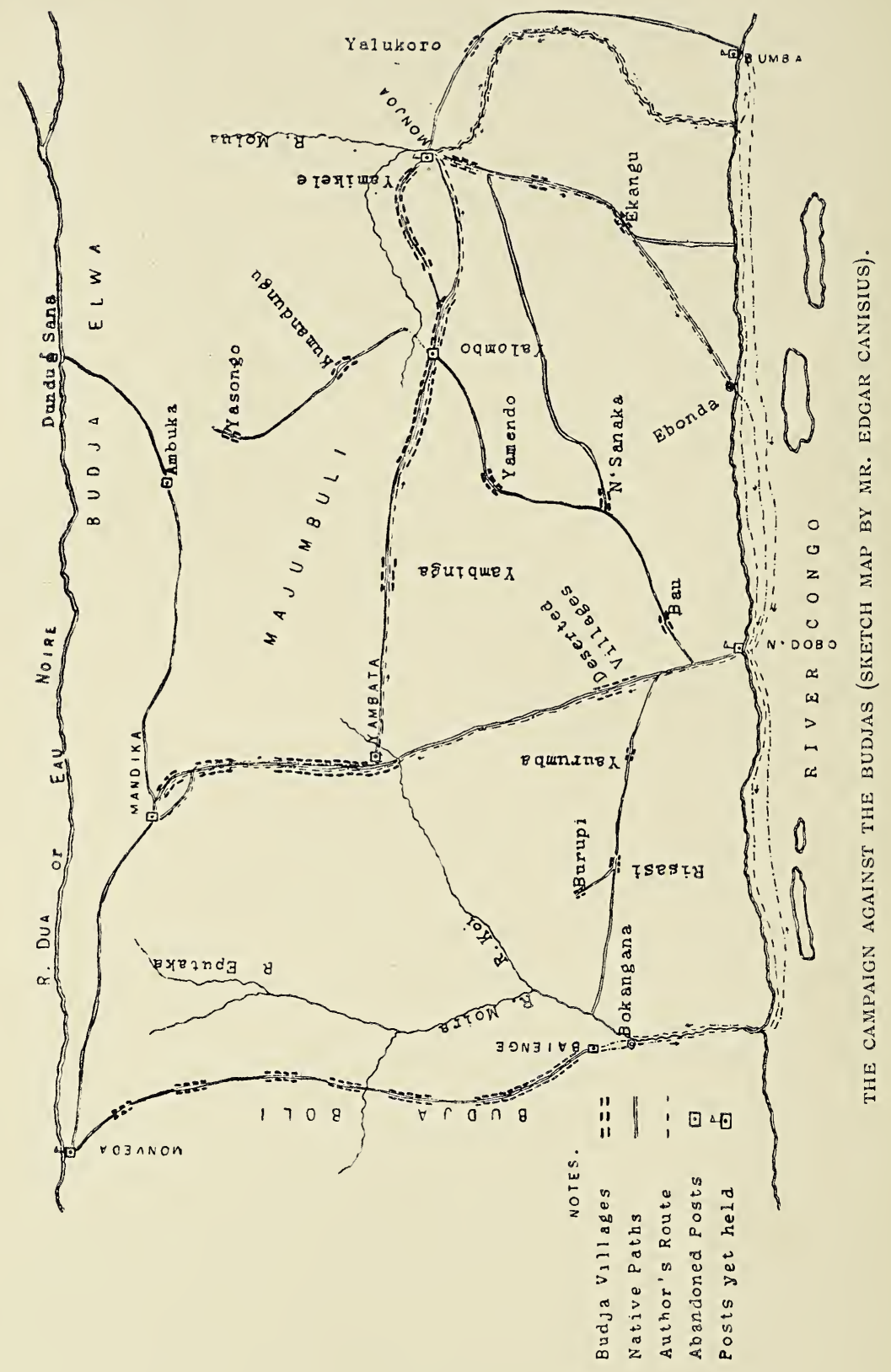


blazing sun. The perspiration poured from us, and our thirst was unquenchable. To make matters worse, we could procure nothing but slimy, tepid water from occasional stagnant pools found near the villages. It seemed to me that the problem of water-supply must have been one of the most serious to be solved by the village sages. During the rainy season there was apparently no lack of water, for the surrounding country seemed to be largely swamp, but of the latter in the dry season nothing remained but stagnant pools, to which wild men and scarcely wilder beasts came to refresh themselves. As our party moved through village after village, preserving as nearly as possible a hollow-square formation, with scouts in advance carefully beating the bush to discover any ambush which the natives might have prepared for us, a long line of smoke rose heavenward in our rear. This was the explanation: a party of men had been detailed with torches to fire every hut that had not already been burned by the detachment which, under command of the lieutenant, had passed ahead of us; and, as we progressed, a line of smoke hung over the jungle for many miles, announcing to the natives far and wide that civilization was dawning in their benighted forests.

The Budjas in their wars know but one system of tactics, namely, the ambuscade, and they owe repeated victory over their enemies to the cunning with which-as we ourselves were to experience to our great cost - they arrange these ambushes. When fighting among themselves, isolated bands will sometimes meet and engage in hand-to-hand encounters in the open, but their usual practice is to lie in wait for and surprise the enemy. Since they have found it necessary to combat a new and more dangerous enemy in the rifles of the white man, they have perfected their method, and with almost invariable success, for even the best of negro soldiers are usually unable to withstand a sudden onslaught, but throw down their guns and seek safety in the jungle. Therefore we had all been instructed that our first duty, in case of an attack, was to hold the men in their places; for if a few Congolese soldiers give way, the whole band invariably follows suit, panicstricken. Our men were made to understand that the first who gave signs of bolting would be shot in the back. I doubt, however, whether even this threat would have prevented them taking to their heels in a body had the Budjas suddenly issued from the 
bush. We called our men n'taba na Umangi (Umangi goats), for most of them came from the camp of instruction at the place named. They were certainly more like goats than soldiers, and we were all very doubtful of the consequences of an attack until our column was joined by a detachment of Maganzulus, one of the fighting tribes of the Uelle region.

When preparing their ambushes, the Budjas generally select a space between two villages sufficiently clear of bush and other obstructions to give the warriors a clear field for a swift charge. As already described, the growth of bush which has taken the place of the primeval forest in the immediate vicinity of the villages forms an impenetrable hedge on each side of the path. Behind this curtain of foliage the Budjas partially clear a space, carefully cutting out some of the undergrowth, so as to enable them to easily glide through it into the open space crossed by the road along which the enemy must pass. So carefully and cunningly are these places arranged that not even the sharpest eye can find a trace to arouse suspicion, and it is only by constantly beating the bush on both sides that an ambush can be found. The natives have learned that the white man invariably follows the main paths on account of the difficulty of marching through the jungle with boxes of provisions and other impedimenta, and consequently, when they learn of the advance of a body of soldiers, they simply camp behind the curtain of vegetation, even for weeks if necessary, and await his arrival. If it be decided by the chiefs that the moment for attack is not favourable, or if their ambush be discovered, they quietly withdraw into the jungle and let the column pass, awaiting a more favourable opportunity for attack. While lying in wait, the women bring food in baskets, which are afterwards utilized, in the event of victory, for carrying off the flesh of the slain. I have heard that they even eat the bodies of their own slain, but have never been able to confirm this statement when questioning those blacks familiar with Budja habits. I think, however, that it is highly probable, for the craving for animal food is very strong with these people, who seem to possess no domestic animals save dogs, and are restricted in time of peace to a diet of plantains or kwanga and pundo-the leaves of the cassava pounded in a mortar and boiled, sometimes with a little palm-oil as flavouring. We noticed that villages where the cassava or manioc is 
cultivated never attempt to grow anything else. At some villages our foragers found an abundance of manioc in the plantations concealed in the jungle; at others they found only plantains.

An evidence that the Budjas have not long been settled in this part of the great equatorial forest is the utter absence of mature palm trees. Generally, where the native inhabitants have been long settled, groves of tall palm trees exist, but here we saw but a few very small trees. Yet the inhabitants barter manioc for palm-nuts with the Gombés living between them and the river-bank, where palms are abundant. The palm propagates itself, and a nut thrown on the ground will in most cases germinate and produce a young palm. I have followed an old trail leading

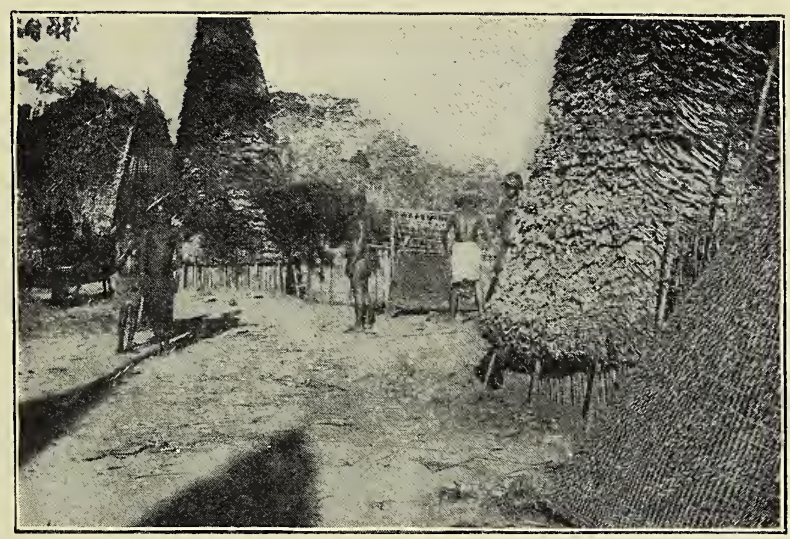

A MOGWANDI VILLAGE.

from this region to the Congo, and have been surprised at the abundance of palms on each side, forming a veritable forest to a distance of several hundred yards. Beyond these belts, however, not a palm could be found. This indicates the existence of a considerable traffic for many years past, as these palm clumps were evidently produced in the first place by the kernels falling from baskets during transport to the interior.

We found many fires burning in the villages, and even cookingpots boiling merrily, but no native could be seen. During wartime the Budjas post their sentinels at advantageous points to give timely warning of the approach of an enemy, and also to warn the warriors lying in ambush on each side of the road 
to prepare for attack. When the enemy is crossing the open space opposite which the warriors are concealed, they rush from both sides in a dense mass, and are upon the foe before the latter has time to recover from his surprise. With their shields covering their bodies, and spears poised, they come like an avalanche, those in front pressed forward by the dense mass behind. The Budja warrior does not throw his spear, but only stabs. Unlike the majority of Africans, he utters no cry when closing in combat; the only warning an enemy has of his presence is seeing him issue from the bush. When charging in a dense mass only a very rapid fire can make the warriors swerve.

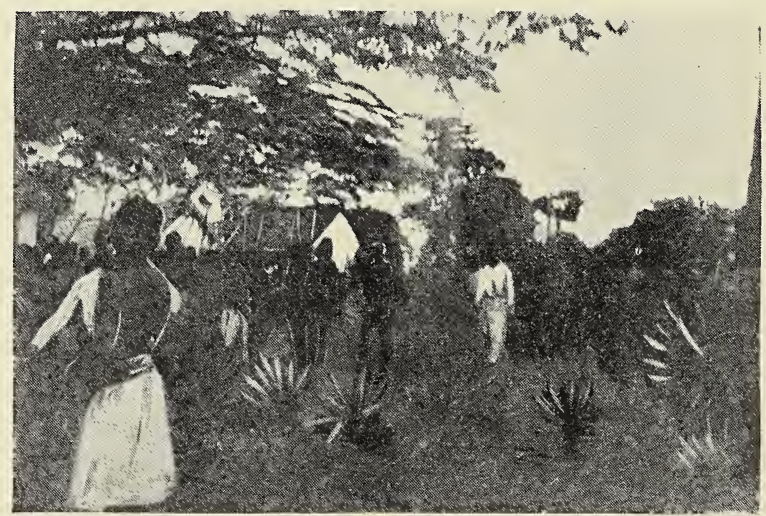

A TRADING POST.

A sudden rush of several thousand of these "braves " upon a body of ill-disciplined "troops" such as ours-many of whom did not even know how to handle the weapons they carried, and who insisted upon marching in the greatest disorder (which it is not always possible to prevent in a country where a march means simply a rough-and-tumble scramble through the bush)-almost invariably results in disaster. Then the unfortunate white man, abandoned by his black poltroons, falls a sacrifice to the cookingpots of the wild men and the avarice of distant speculators.

As we knew that in previous campaigns against the Budjas several columns had been cut to pieces in this way, we anxiously watched our scouts flit from side to side, peering into the thick foliage, expecting every instant to hear the crack of their rifles. 
We were passing through one particularly large village, evidently the residence of the principal chief of the neighbourhood, when I stumbled over an object lying concealed in the grass, and, on peering down, perceived it to be a human skull. One of the soldiers, a Manyema, remarking my surprise, said nonchalantly:

"Kitchwa na askari" ("It is a soldier's skull").

On looking about I saw many more lying in the grass, all white and clean. This was the spot where our chef had been attacked and had lost his thirty men. The heads of the slain had been cut off and stuck on stakes by the roadside, but had probably been taken down and picked clean by the hungry slaves of the village, while the remainder of the "meat" had been divided among the villages taking part in the ambuscade.

The appearance of these skulls had the effect of making me rather uncomfortable for some time, as it did our valiant band, for they closed the gaps in the ranks and held their rifles ready. The carriers caused us much annoyance, for they continually let their loads drop, greatly delaying us. They would also frequently press too much to one side or the other, throwing the soldiers into confusion, thereby earning many a blow from the butt-ends of rifles and the stout stick of the cook, a British subject from Sierra Leone, who was in charge of the convoy.

About noon we perceived the blue golden-starred flag of the Congo above the bush, and soon emerged into a large cleared space where stood the post of Yambata. As we approached, our bugles announced our arrival and were answered from the blockhouse. We found the place occupied by a solitary company's agent and some fifty soldiers, many of whom were sick. There was also a crowd of men, women and boys, some of whom had escaped from the ambush and bore frightful wounds from spear and knife. The population further included a score or more Budja women, tied together with cords and most dreadfully emaciated, and so feeble from starvation that some of them crawled on their hands and knees whenever they had to move. These women were prisoners of war, and it was intended to send them down as slaves to one of the distant posts of the company, this being one of the methods of recruiting labour in the Congo.

The post of Yambata consisted of a manager's house, built of clay, which formed the front, and three other houses in the rear 
some fifteen yards long, which completed the quadrangle. These houses were thatched with leaves, and we were suprised to hear that the Budjas had not yet attempted to throw burning spears upon them, as they could very easily have done, the roofs being very low. Loopholes had been pierced in the outer walls of the rear houses, which were the quarters of the soldiers and others. In one corner a blockhouse of logs had been constructed commanding the front and one side of the post, and on the hostility of the natives becoming apparent, a palisade was added before the agent's house. This palisade Major Lothaire ordered to be removed and so placed as to surround the rear of the station at a distance of two yards from the walls of the other houses, a re-arrangement which nearly entailed the loss of the place a few days later.

We learned that the chef-de-zone, together with the lieutenant and non-commissioned officer, and the lieutenant commanding the police post at Mandika, had left for that place with two hundred and fifty men to ascertain how it fared with the white man who had been left there. They had not been advised of our intended advance upon Yambata, but had expressed their intention of returning in a few days. We therefore decided to remain and await their arrival, occupying our time in reconstructing the defence of the post. An additional blockhouse, similar to the one already existing, was commenced in the opposite corner, and the place generally strengthened. I noticed, however, that the front remained quite open, and, with the exception of the blockhouse which commanded that side, possessed nothing to guard against an attack, the two flimsy doors which gave admittance to the interior being scarcely worth the name.

Our stay at this place was far from pleasant, for not only were the quarters of the whites very limited, but the interior of the palisade was so crowded with blacks that one had to make use of a stick to force a way through them. On the bare ground in the quadrangle they lay in batches, the unfortunate Budja women faring the worst, being bound together and exposed to the fierce rays of the sun and the chilling cold of the night-naked, miserable creatures, kicked and beaten by the brutal soldiers and their still more brutal women. 
I have always noticed that the greatest delight of these negroes is to be in a position to domineer over their fellow-blacks of another tribe. Then they thoroughly enjoy themselves, raining blow after blow upon a well-tried and defenceless prisoner without rhyme or reason-merely for the exquisite pleasure of witnessing human suffering. It is, perhaps, fortunate for the white man that the negro invariably detests his neighbour of another tribe with a deep and lasting hatred, prompting him to take part in any scheme likely to give him power over his brother black. It has been solely by playing tribe against tribe that the whites have been able to

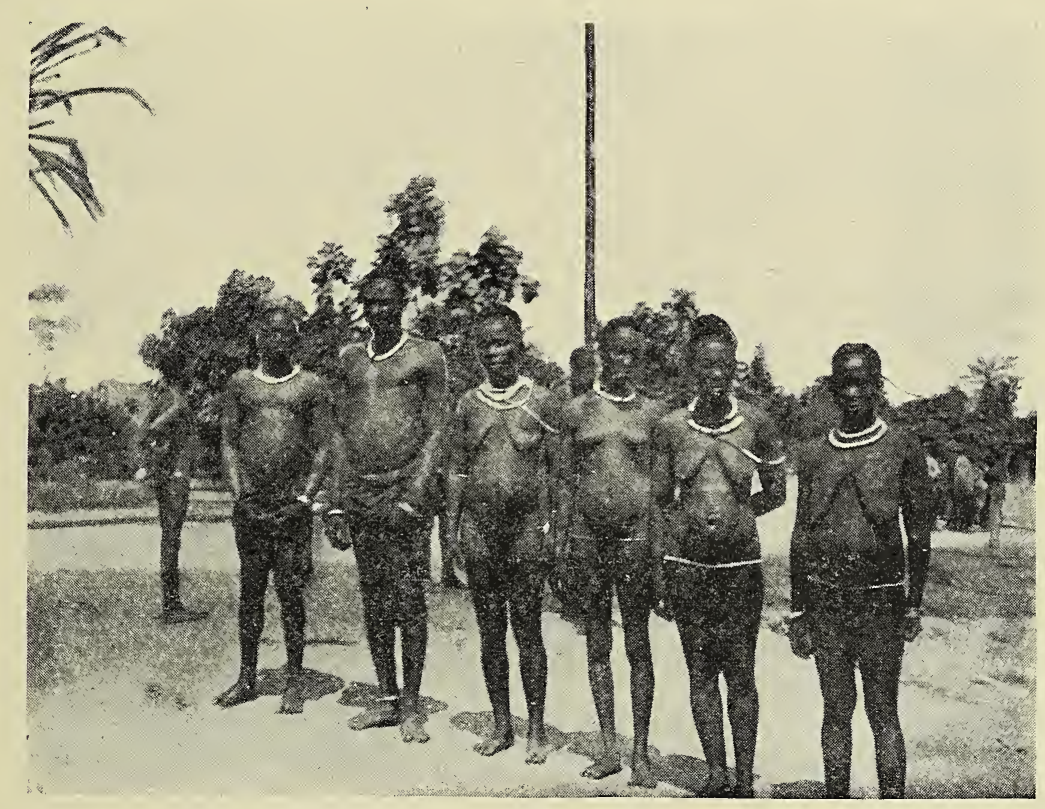

MOGIVANDIS,

maintain a footing in Africa. The day is perhaps coming when the aborigine will see the folly of this; and should he ever do so the reign of the European is over, so far at least as tropical Africa is concerned. I am convinced that that day is not so distant as some enthusiastic "colonisers" affect to believe. There are unmistakable signs, in the Congo at any rate, that the prestige of the white man, as represented by the Belgians, is rapidly waning. The awe with which the savage formerly regarded the white, to whom he, in his superstition, ascribed superhuman powers, has 
largely given way to a feeling of contempt, a fact which will surprise no one familiar with the character and habits of the Congolese Belgians.

The question why the Anglo-Saxon has succeeded in so effectively subduing and ruling the dark races of the world is easily answered by one familiar with the methods of other white races who have attempted a similar work. As a general rule the English utilize for administrative purposes men of far better education and breeding, and who have the sentiment of self-respect strongly developed. Some are not without characteristic faultsthey are "English, you know, quite English"-but few lack that happy genius which demands just dealing with the aborigine, and

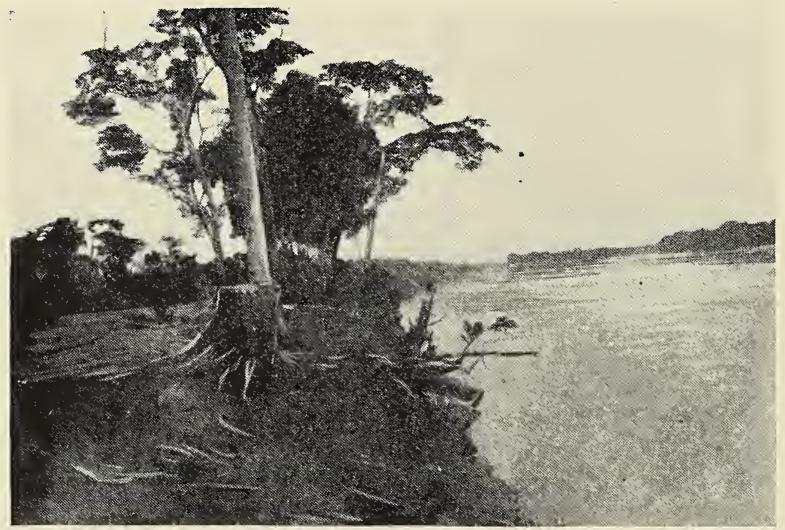

A VIEW ON THE ARUWIMI RIVER.

challenges a better understanding of the workings of the savage mind. These qualities are-and my opinion is formed after years of observation-utterly wanting in the Belgian even of the better class, of whom, unfortunately, few are found willing, for the scandalous pittance offered them, to risk health and renounce the luxuries of European life in order to promote the civilization of the jungle. Thus the grande cuvre of King Leopold has been entrusted to men who throw themselves with zeal into the oppression of the blacks, made necessary by their employers' greed for immediate gain. A large majority of these men, reared in the not too healthy atmosphere of the barracks, have but two ideas in their treatment of the native-arbitrariness and swift punishment for trivial 
offences. Others, suddenly transplanted from their primitive villages and their peasant occupations, are aghast at the difficulties and privations of a life of which they had never even read. The petty annoyances which are inseparable from contact with the savage are to them offences of the deepest dye, to be suppressed with severity; they become discontented and irritable, and, having little moral courage, often give way to nostalgia, to an irresistible craving for flat fields, evenings at the cabaret lambic, and other features of peasant life in Belgium.

Of the higher functionaries, the majority are officers of the Belgian army who have left their regiments for their regiments' good and for the benefit of their creditors. They are chiefly of the lower commissioned grades, and usually men who have risen from the ranks. Until my first contact with this class of men, I had always held the belief that officers in any army were gentlemen. I was disillusioned on this point, however, very soon after my first association with the Congo.

These remarks are particularly apropos of the men under whose orders I found myself placed during my sojourn in the land of the Budjas. The commandant under whom I served reminded me much of one of whom I had read and who was so cleverly subdued by the doughty Captain Kettle. As arrogant as ill-bred, and cowardly as boastful, this officer was a type of the men one often meets in the higher ranks of King Leopold's rubber-hunters. The ignorance of some of these is really astonishing to one accustomed to look upon an officer as at least an educated man. The pleasure they find in making their subordinates feel their inferiority is the inevitable consequence of ill-deserved promotion from the ranks. "Je suis officier Belge" is an ejaculation so frequent that, to escape it, one would fain believe such rank to be the highest honour on earth. Their conversation invariably reverts to the life of the barracks, criticism of their superior officers, and adulation of the Belgian army, until one is forced to the conclusion that the German, French, and other hosts are in comparison mere corporals' guards. Nor are they too tender in their comments on brother officers, whom they backbite in a fashion which impressed me as most offensive. Of course there are exceptions to this rule, made the more brilliant by their rarity. The Belgians' anxiety to acquire decorations is 
one of the characteristics of their race, and is as absurd as the facility with which the said decorations are obtained.

The expedition now assembled in the vicinity of Yambata was nominally under the orders of a commandant of the Force Publique, but it was in reality Major Lothaire who conducted the campaign, the commandant merely executing the orders received from him. A large portion of the force was composed of company's men; but, whether State or company, all alike looked to "Lopembe" as their chief, the remainder of the whites being merely " "boys' of Lopembe." On the return of the detachment which had gone to Mandika, the expedition was reorganised in four platoons of fifty men, each under the command of a white man. Rather

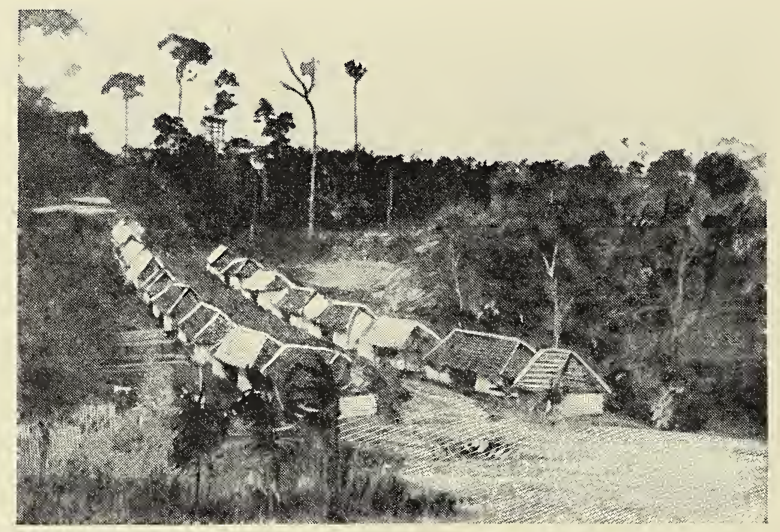

SOLDIERS' CANTONMENTS.

to my surprise, an Italian non-commissioned officer of the Force Publique was directed to remain at Yambata with the "weeds" and the sick, while I was ordered to take command of his platoon. As I had come out with the idea of being a peaceful rubber-trader, this was a considerable change from my original plan. My men were all State soldiers, mostly Bango-Bangos from the region of Lake Tanganyka and Abarambos from the Uelle. These races are not considered as "fighters," and on looking over my decidedly awkward squad I felt far from reassured. However, I decided to make the best of them. Although I might have been justified in refusing to render military service to the State, being a civilian and not liable to military service, I considered that, as the company 
and State were much the same thing, I could not well refuse. Moreover, another company's agent was also given a platoon of n'taba na Umangi to command, so that I could not consider myself worse treated than he. Indeed, a refusal might have had exceedingly disagreeable consequences, for I should, perhaps not unnaturally, have been credited with other than the real motives, and thereby earned the contempt and dislike of my superiors. I had also heard stories of the disappearance of "obnoxious" agents as consequences of an accidental bullet in the back and other expedients equally unpleasant. To be quite candid, I was, on the whole, by no means disinclined to accompany the column, for I much desired to witness the operations which were to be conducted with a view to compelling the Budjas to accept the benefits of our rubber régime.

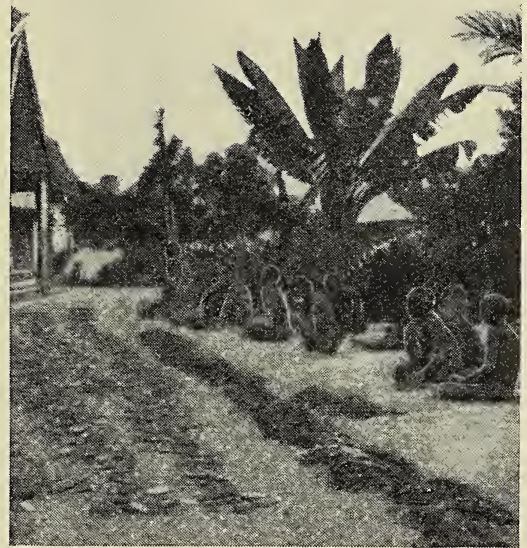




\section{CHAPTER VIII.}

AT YALOMBO.

How War is Conducted in the Congo-Counting the "Bag"-Budja Prisoners-A Motley Crowd-Attack on Yambata-A Wanton Murder-Major Lothaire's Responsibility-The Budjas and Their "Mono"-Arrival at Yalombo-"Telegraphy" in the Jungle-Kumandungu Appears-Experiences at Yalombo.

Having reorganised our "army," we started off towards the post of Mandika. The first day we camped at a place only four hours' march from Yambata, constructed the usual light stockade, and sent out detachments to "patrol" the jungle for Budjas. The men were drawn up outside the palisade and given their instructions. Naturally I thought that I should go with my squad, and was preparing to do so when I was told to return to the camp, as the men "would arrange matters under their black corporals." I therefore re-entered the stockade, where I found all the white officers seated under the rough shelter which had been made engaged in smoking cigarettes, drinking absinthe, and playing cards. This, I thought, was a rather easy method of making war, and one altogether at variance with my preconceived notions on the subject. The system certainly has its merits, for the "leader" can remain in the cool of the shelters instead of being obliged to scramble through jungle and swamp behind his men, to keep up with whom often requires a frantic effort. Certainly, when there is any butchery in prospect, the blacks can be depended upon to accomplish it as well when alone as when accompanied by a white man, especially if the proposed victims be women and children, as is usually the case.

While the patrols were out, ostensibly scouring the bush for natives, the carriers and other camp-followers were sent on a foraging expedition under an escort, and in an hour returned laden with plantains, which were distributed among the force. 
The game of cards occupied my companions all the afternoon. This consequently left me at liberty to retreat into the cool of the jungle-where ants are the chief annoyance-in order to escape the heat and smoke of the camp fires and the myriads of "elephant" flies, black insects much resembling bees, which are among the worst pests of bush-clearings in this part of the Congo. They swarm all over one, especially when freely perspiring, literally cover the face and hands, and generally drive the victim to a state of semi-desperation.

Towards sunset the three squads returned. The "hunt," however, had been but indifferently successful. As each squad

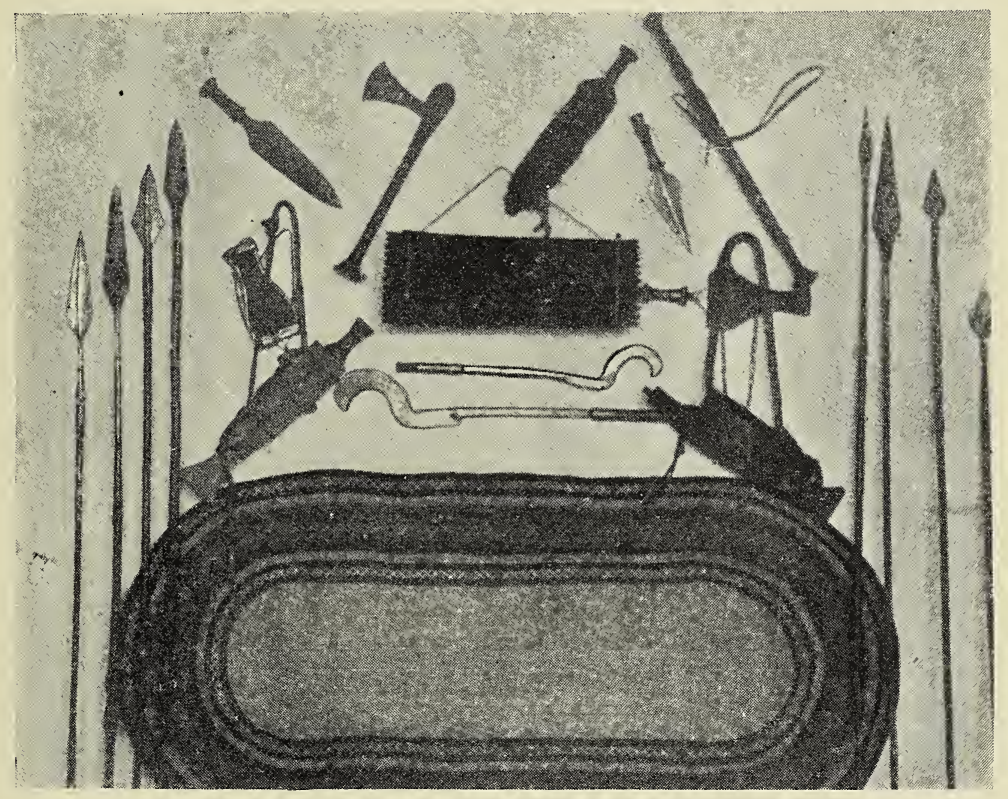

NATIVE WEAPONS.

arrived, its chief, a corporal or sergeant, reported to the Major the result of the day's work. The usual manner of presenting such reports may be thus described: if the corporal and his men have succeeded in shooting many natives, the jack-in-office brings up the spears and shields of the warriors slain; but for the women and children he keeps a reckoning by means of small sticks, which he ties in a bundle and hands to the white commander. On the present occasion the spears and shields were conspicuous by their absence, and the bundles of sticks were very diminutive. 
Consequently all the raiders were soundly rated by the Major, whose comments were decidedly uncomplimentary. Only one out of the three patrols could furnish any of the required evidences of their courage, and I strongly suspected that the other two had quietly crept into the jungle and remained snugly hidden until the moment came for returning to camp, when they told the story, concocted beforehand, of having been far and wide without lighting upon any trace of Budjas.

The old familiar method of cutting off the hands of the slain has been abandoned since the commissaire-de-district at Equateur brought down a storm of indignation upon his head for employing this system of obtaining undeniable proof of the "bag" of his soldiers. We were well aware that the "stick system" of accounts was liable to errors and exaggeration, but could, as a general rule, rely upon a proportion of ten "sticks" to one "spear." Often enough, during the course of the expedition and in the quiet of the evening, I have heard the men boasting to one another how many Budjas they had "potted," and so could form a pretty accurate estimate of what each squad had accomplished.

Moreover, the lieutenant kept an accurate account in his notebook of each day's proceedings, so that we were always able to calculate how the "war" was progressing.

The following day, February 3rd, 1900, we advanced another four hours towards Mandika and stockaded, as usual, in a village. All huts which had escaped the torch were set on fire save a few near the camp, the roofs of which were "unshipped" and carried into the stockade to form shelters. As on the previous day, patrols were sent out. This time they were composed of a different set of men, those who had been out the previous day remaining to guard the camp and escort the foragers. The result was slightly more gratifying, the total killed being forty, among them some "spears." Moreover, an Albini rifle, which had probably been taken in the massacre of the chef's escort, was recaptured. The Budja who possessed it, upon seeing the soldiers, hastily pulled the trigger, but, unfortunately for himself, he was insufficiently acquainted with the manipulation of the weapon of the mundele, and placed the butt against his face. The heavy recoil, of course, nearly knocked him down, and the soldiers had time to "plant" several bullets in him before he could recover from his surprise. 
At this camp water became very scarce, and nothing but thick slimy liquid of a whitish colour was obtainable. We had with us pocket filters of three different systems, and it was necessary to pass the water through all three before we were able to obtain a glass of drinkable liquid. However, this disadvantage had its compensations, for wherever water was scarce the mosquitoes were also absent.

The following day we marched considerably further than on the previous days. Having formed our stockade, the Major, the commandant, and one of the lieutenants started off with half the force for Mandika, which by a jungle path was only an hour's march distant, while the other lieutenant and I remained to guard the camp. In the evening they returned, bringing a number of prisoners chained together who had been found at the "factory." Among them were several Budja men, and I must confess, concerning these people, that I have never seen a more wild and animal-like expression on the human face, although I have lived among many of the savage peoples of the world. The horrible manner in which they are tattooed, their ears distended in great lobes, their staring eyes and filed teeth give them the air of true anthropophagi. They are a rather lanky people, all muscle and no fat, and the specimens we now had with us proved the race to be endowed with almost incredible endurance. All were compelled to carry heavy loads, each of which had previously required two men to transport, but which they carried day after day without apparently much effort, until they finally succumbed to starvation and smallpox.

In this chained gang were also several soldiers of the company who had been caught asleep while on sentry duty, and had been disarmed and were now to be utilized as carriers, after receiving a sound flogging.

A motley crowd indeed now composed our column. These were from nearly all the tribes in the Congo, and a score or more of distinct tattoo markings could be seen at the same time. There were Bango-Bangos and Wabudjwa from the lake region, Bakussus from the Manyema, Batatelas and Balubas from the south, Banzas and Mogwandis from the Mongalla, Bapotos and Bangalas from the main river, Likwangulas and Mobangis from the Itimbiri, Wangatas from Equateur, Azandés from the north, and free-born British 
coast niggers from Sierra Leone and Lagos. All this hungry and tattered crew had been collected from far and wide to aid in the "production" of rubber, and the consequent filling of King Leopold's coffers.

To keep order in this cut-throat crowd was a task of no small dimensions, and "Dame Chicotte" was kept briskly on the move the greater part of the time.

Our return march to Yambata was more rapid than was the outward journey. The patrols were sent out on each side with orders to rejoin the column at that place. Early in the morning we heard the rifles of the advance guard of our column, and occasionally passed the body of an unfortunate slave or woman who had evidently returned to the village in search of food, and

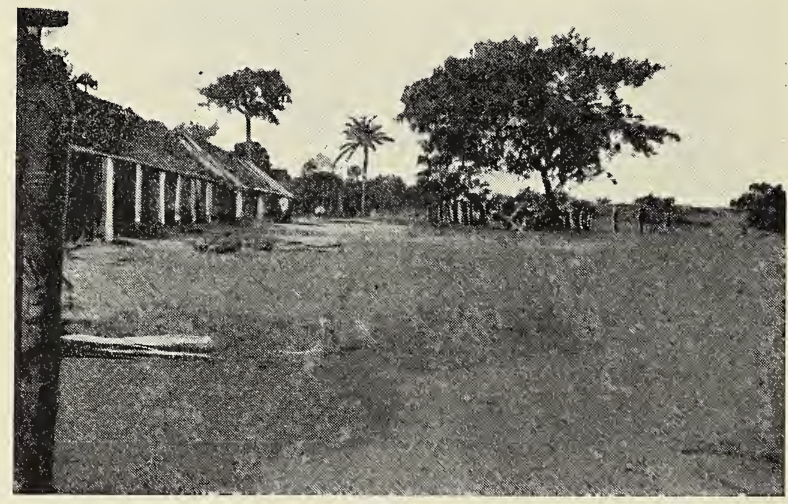

SOLDIERS' QUARTERS.

had not expected us back so soon. One case impressed me greatly-that of a young girl who, surprised by the scouts, had evidently attempted to conceal herself by jumping into a pit beside the path, some ten feet deep. The merciless "soldiers" had, however, espied her, and a bullet soon made the pit her grave.

On our arrival at Yambata we were treated to a piece of news which did not surprise me. The post had that morning, at about four o'clock, been attacked by a numerous band of natives. Certain Budja women who had been purchased by some of the soldiers of the garrison had evidently informed their brothers of the exposed state of the front face of the post caused by the removal of the stockade. The approach had been 


\section{The Curse of Central zitica.}

made so stealthily that a corporal who was just outside the blockhouse was speared to death without being able to give an alarm. When finally they were discovered, the Budjas were already entering through the door which led from the verandah into the quadrangle in rear of the house. The sentries in the tower first opened fire, and their example was soon followed by some of the soldiers within. This, however, did not prevent the invading warriors wounding severely several women and boys whom they encountered. It being pitch-dark, the assailants could not be seen as they sneaked swiftly by, but the soldiers in the blockhouse opened so hot a fire that they probably judged it discreet to abandon the attack. After the soldiers had once begun to fire they

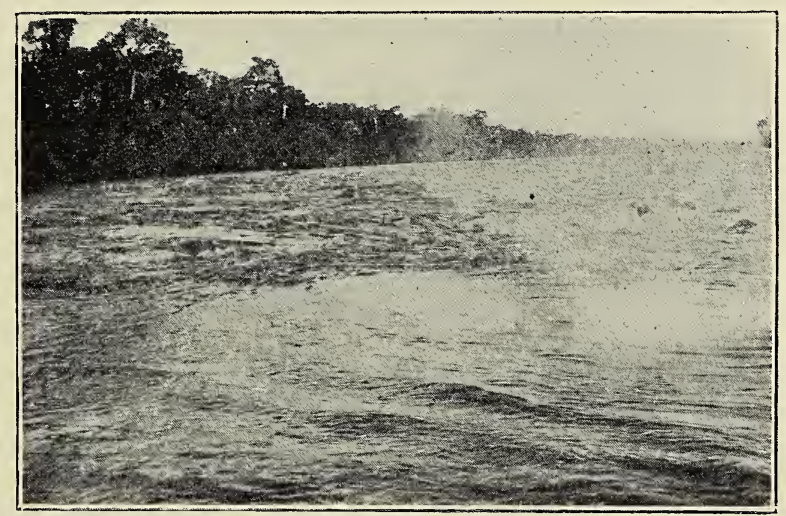

THE RAPIDS OF YAMBUYA, OPPOSITE STARVATION CAMP.

kept it up, and a number of them who were lodged in a large rubber drying-shed at the back of the factory continued to fire into the darkness, bullets whistling in all directions. Meanwhile the three whites did not dare to open their doors lest the Budjas might enter the rooms, which all opened on to the verandah, and it is fortunate for them that they did not, for they would have been speedily mowed down by the hail of bullets which the soldiers continued to pour along the front face of the post, many of which struck the wall of the house, some even penetrating the doors and windows. At dawn the bodies of seven Budjas were found, the result of the expenditure of some fifteen hundred rounds of ammunition. 
I had good reason to congratulate myself that I had not been one of those who had remained at Yambata, for I had selected as my sleeping-place the verandah where the attack was made; the room which the manager occupied, and which he had offered to share with me, proved too hot for my taste, and I found the verandah more cool and comfortable, and also less frequented by mosquitoes. Had I been sleeping there at the moment of the attack, I should either have been found by the spears of the Budjas or the bullets of our own soldiers, and thus enjoyed the honour of inaugurating at Yambata the cemetery, without which no Congo station is complete. Warned by this event, the Major decided that some defence in the front of the post was necessary, for, although the blockhouse commanded that side, it was of no advantage in repelling a night attack. We therefore took from the stores of the factory several rolls of the brass wire which is used to pay the natives for their produce, and constructed an entanglement in such a way that any rush of the natives would be impossible. An excellent provision for defence can be assured by running a wire all round the post at about two feet from the ground and hanging thereon small bells, which tinkle whenever the wire is touched, thus warning the sentries. I strongly recommend the Congo Government to send out a large supply of barbed wire, to be stored in the chief stations of each district in anticipation of the time when all the whites will be called upon to defend themselves from the storm which, sooner or later, is certain to burst over them.

After having put the post in a proper state of defence we resumed our march, this time in an easterly direction, following a long line of villages which reached from Yambata to Monjoa, a company's post due north of Bumba on a small river called the Malua. Our strength now consisted of some two hundred men and six whites, having been reinforced by a band of Maganzulus who had come from the Mongalla, where they were established in one of the company's posts. Great confidence was placed in these men, who had acquired, during a number of years, a reputation as fighters when engaged in "subduing" the weak and cowardly tribes of the Mongalla. They were to find, however, that the Budjas were of different metal, and that the game of massacre and pillage which they had carried on among the Mogwandis, Banzas, 
Gwakas and other insignificant tribes was here more dangerous and less profitable. The ease with which they had carried on their expeditions in the Mongalla was their undoing, for they had become insouciant; they had learned to regard with contempt the man with the spear. However, up to the day of their death they rendered excellent service, for henceforth the greater portion of the daily "bag" was due to their efforts, and the bundles of sticks became fatter and fatter each time Jumbo, their chief, handed in his account to the Major.

Our camp was pitched in the forest, where we slept soundly and undisturbed either by Budjas or mosquitoes ; moreover, during the daytime we were free from the elephant-flies, which persistently annoyed us while following the line of villages. One of the men, who had been out foraging on his own account, returned with a small Budja child, whose foot had been wounded by a bullet. The infant, however, was released, and gladly made off into the forest.

On the following morning we arrived at the first of a long line of villages, and during the subsequent march passed a great many newly-made clearings, evidently intended for plantations. The road became abominable on account of the many huge trees which had been cut down and now lay across the trail. Finally we emerged from this labyrinth into a village which appeared to have been newly constructed. We had, however, gone off the proper path and were in doubt for a few moments in which direction to proceed, for the few men who knew the way were absent with the patrolling parties. We soon, however, recovered the path and, arriving in another and older village, halted.

As no one knew the name of this place, the prisoners brought from Mandika were interrogated. Among them were a young woman and a little boy, who, in reply to the question previously put to others and always answered in the negative, said that they were unacquainted with the name of the place because they came from the neighbourhood of Mandika and were quite ignorant of this part of the Budja country. This was in all probability a perfectly true statement, for Mandika was, by the line of villages, quite four days' march distant, and natives very rarely venture so far from their homes-a general remark especially applicable to women, who are usually occupied in the plantations of their 
lords. Therefore I doubt not that the unfortunate creatures were as much strangers to the place as we ourselves, and that had they been able to give the required information they would gladly enough have done so. Nevertheless, the commandant insisted that they must know, and finally, in great wrath, ordered the two wretches to be taken out of the square and immediately shot. The cruel command was no sooner given than obeyed. The unfortunate woman, especially, faced death with the fortitude of a martyr of old, and looked straight down the barrels of the rifles which the brutal soldiers, with undisguised glee, levelled at

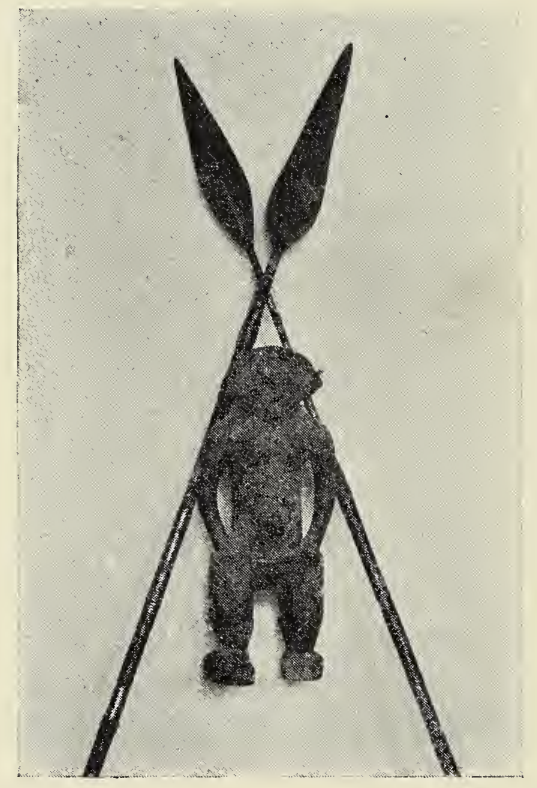

A FETISH.

her head. The fatal shots rang out simultaneously, and two more victims were added to the already formidable list of Bula Matari's Afro-Belgic "civilization."

While it is quite true that the commandant gave the order for this brutal and wanton murder, Major Lothaire it is who should be held primarily responsible. Nothing was ever done during this expedition without his knowledge and assent. He was always practically in command, and it is not improbable, therefore, that the order emanated directly from him. 
Not without good cause has it been alleged that most of the massacres and atrocities which have given such infamous notoriety to the Mongalla concession may be placed directly at the door of Major Lothaire, whose reputation for despotic acts has been fully established after a career in the Congo covering many years. The system of butchery which has been inaugurated in the Mongalla concession is directly traceable to him, although he has always been sufficiently wily not to place any written proof of this where it could be brought against him. His reputation was far too well known among the men who were to carry out his instructions to

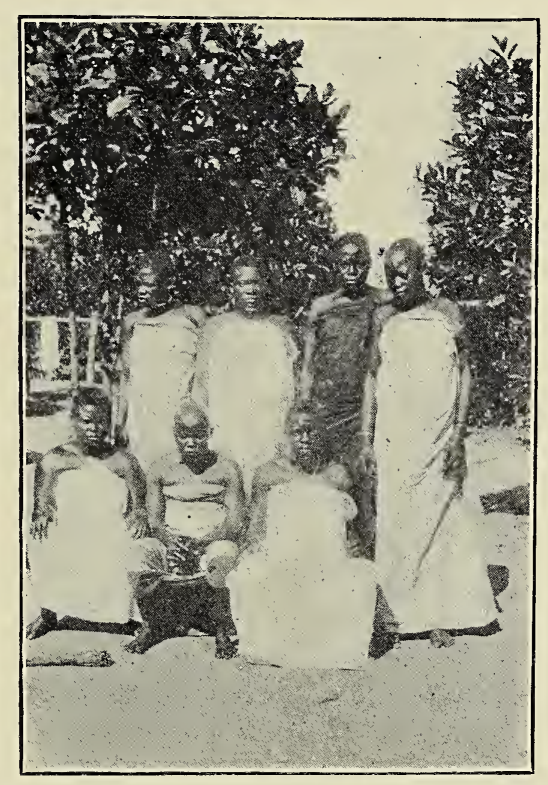

GROUP OF MANYEMA WOMEN.

admit of any doubt as to the real significance of his methods in dealing with the natives. Some understrappers have been punished for committing crimes for which, undoubtedly, the Major was morally responsible. His hasty and despotic treatment of the blacks, as shown in the massacre at Bau, had due effect upon his subordinates, by whom he has been regarded as a hero since the day he lynched a British subject, Stokes, a white man, in the Zône Arabe. To imitate him was, therefore, "the proper thing," and every low-born and illiterate person who was placed in charge of 
one of the company's numerous posts soon imagined himself a despot on a smaller scale, and boasted loudly of the number of natives massacred by his order. This commenced on the Major taking charge of affairs on the Mongalla, and only ceased with his departure. It is, however, mere justice to add that Major Lothaire is a brave, usually even-tempered, and, I firmly believe, not naturally hard-hearted man. For many of his faults and much of the ill that he has done, the system of the Congo must be held primarily responsible.

The bodies of the two unfortunates were left lying by the roadside, to the great delight, no doubt, of the villagers, who were thus provided with an unexpected but not less welcome supply of fresh meat.

As we continued along the main path, which was now fringed as usual by huts, we heard the crack of Albinis on both sides, advising us that our blood-hounds were on the scent. We kept along the line of villages, the reports of the rifles becoming fainter and fainter as the soldiers pursued the natives further into the jungle. We learned afterwards at Yalombo, from a chief of the Budjas who pretended to be friendly, that an ambush had been prepared for us near the village of Yambinga, where we had camped, but that the warriors, hearing the firing of the patrolling parties, and not having sufficient confidence in their mono or fetish, decided to withdraw, and that a number of them in their retreat had stumbled upon some of the soldiers and been killed.

The Budjas, like most Africans, have an unbounded faith in their mono or talisman, and it is often this superstitious confidence which emboldens them to attack with the greatest coolness and courage. The mono may consist of any object-a leaf, a pebble, or a bit of wood, according to the whim of the fetish doctor. From some of the dead Budjas we took small packets, the size of a walnut, of a black powder, probably charcoal, tied up in leaves and attached to the neck by a cord. Later I saw that they smeared a kind of red pigment upon their bodies and their spears. Whenever a fetish doctor has established a reputation for making "strong" mono, natives from far and wide come to him to purchase a supply. Should the talisman bring success, it attains great popularity, and is frequently sought by distant tribes who scarcely know whence it comes. I was informed that the black-powder mono, which was so 
much in vogue at the time I write of, had been seen among the Mogwandi people inhabiting the banks of the Mongalla and knowing little or nothing of the Budjas, who are to them as alien, so far as inter-communication is concerned, as the Bakussus. The fetish doctor, of course, grows rich on the sale of his speciality, and should anything go wrong, has always some plausible excuse to account for the failure.

When the patrols came in that evening we had quite a collection of native weapons to choose from-spears, shields and knives. The shields-made of rattan and ingeniously wrought and sometimes quite ornamental, generally including a design in black, presumably the coat-of-arms of the warrior who bears it-we threw upon a fire and burned, while the spears and knives were retained by the soldiers who took them. Their ultimate destiny, no doubt, was to be sold to the white men passing up and down the river, who pay exorbitant prices for such articles. A total of sixty was the result of the day's hunt, and, as the proportion of spears was unusually large, all concerned were accordingly pleased. The capture of so many spears showed the presence of warriors in this region, and extra care was consequently taken. The enemy had evidently assembled here, for on our march towards Mandika very few males had been seen.

At this camp plantains in abundance were found, and even the prisoners were allowed to gorge themselves; nor did the whites fail to supplement their meagre diet of corned beef and rice with well-baked plantains, which, to a hungry man, taste fairly good with the addition of a little butter and salt.

The next day we camped some three hours further on, patrols being sent out as usual; but they were less successful than recently, only thirty of the enemy being accounted for, while one woman was brought in prisoner.

The following day, the 11 th of February, we arrived at Yalombo, where it had been the intention of the chef to establish a factory. For this purpose he had, some time previously, left a black sergeant and eighteen men. These men had taken possession of a portion of a native village, where they constructed a light palisade. When, however, the natives united in an effort to throw off the company's yoke, they attacked the place. The sergeant and his men were, at this juncture, engaged in clearing off the surrounding bush in order 
to have a space ready for the construction of a station when a white man could be found to act as agent there. They had just time to rush back and throw themselves into the stockade when the Budjas arrived. Three of their number, not as quick as the others, or being further away, were speared, but the attack on the palisade was repulsed, for the men within it opened a hot fire upon the enemy and killed a score. The sergeant, seeing that it was useless to maintain a small post with natives hostile, and not caring to risk starvation, decided to abandon the place, and finally rejoined the force gathering at Yambata. We were told that the natives came soon after, and, disinterring the bodies of the slain, held a great feast.

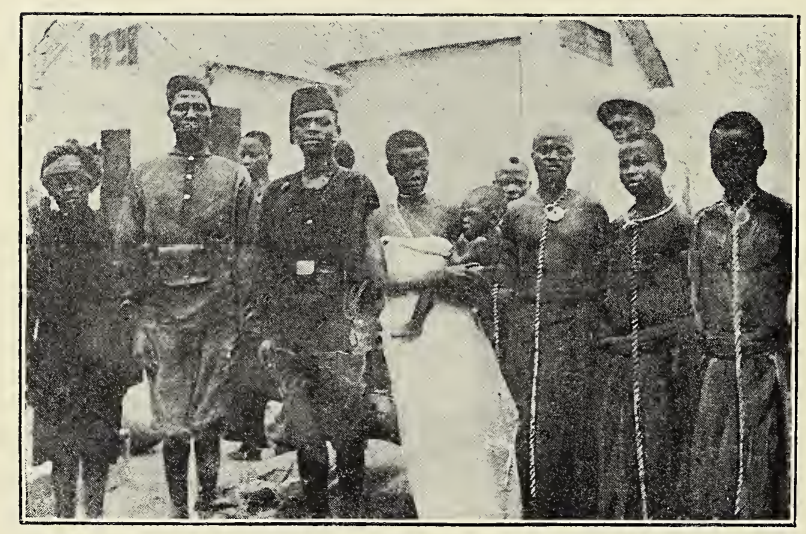

PRISONERS.

The space cleared for the construction of the trading station amounted to some ten or fifteen acres, and was situated upon a slight elevation, from which the ground sloped on one side to a small swamp-bordered creek. In the centre of this space a site was selected for the post, and the stockade commenced forthwith. Some twenty yards square were marked off, poles being cut from the forest and planted firmly in the ground. One corner of the stockade rested on a large ant-hill, and upon this a blockhouse similar to that at Yambata was constructed.

While the carriers and the soldiers were occupied in making ready the new post, at which it was decided I should remain as manager, the best of the men were sent out to patrol the country 
on all sides. The Maganzulus, forming a special corps, were attacked by a band of Budjas, who retired, leaving thirty killed, and these, together with the women and children, made the largest bag of the march. An effort was made to open up communication with a chief of the neighbourhood called Kumandungu, who had hitherto proved friendly. The sergeant previously stationed here, and now with the column, stood each evening upon an ant-hill and shouted the chief's name for an hour or so, while the woman who had been made prisoner was liberated and ordered to seek Kumandungu and persuade him to come in to the post.

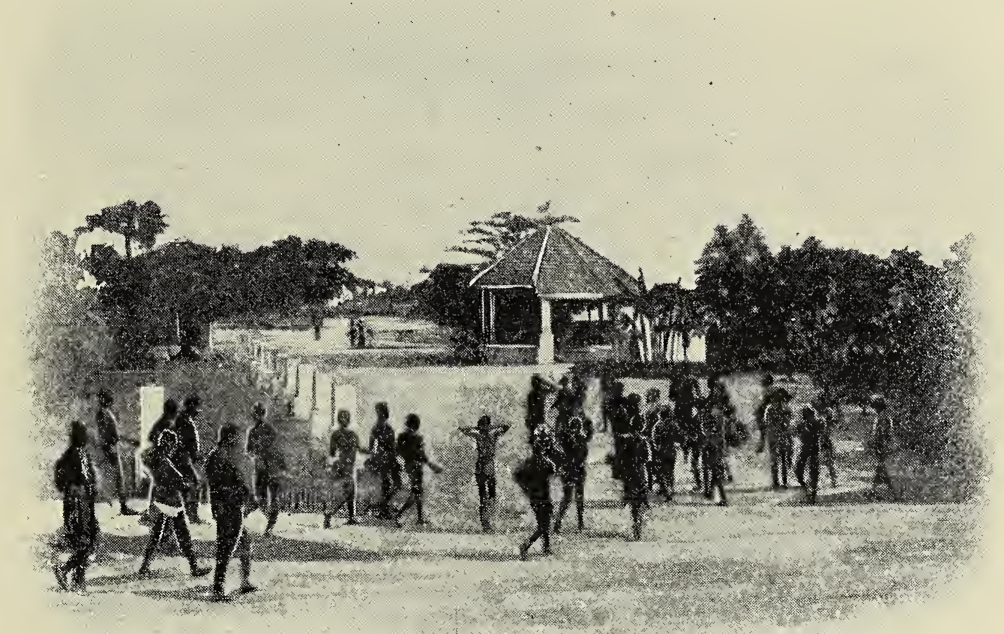

STANLEY FALLS.

Frequently at night we could hear the Budja war-drums beating a message of defiance, which was answered by a lively march from our bugles. Like all the Central African tribes, the Budjas employ a system of telegraphing by means of these tomtoms, and in a country like that which we now proposed to occupy, where the villages are never far apart and lie in long lines in one direction or the other, a message can be sent for long distances with a rapidity nearly equalling electricity. While on the Lualaba I have often been warned in this way several days in advance of 
the arrival of white men going up or down the river, nor did I ever have need to send messengers when I wished to communicate with the chiefs, Arab or native, in the neighbourhood of the post; I merely called my "telegraph operator" and sent my message "by drum." At Yalombo we had captured one of the Budja drums, which are merely logs of wood hollowed out in the centre, and which, when beaten with a soft-wood stick, give out two distinct notes. We requisitioned one of the Budja prisoners to work the "instrument." The message was to the chiefs in general, ordering them to come in and submit, or pay the penalty of death.

The reply came: "Tumba aringi! tumba aringi!" ("War, war! we want war!")

This did not presage a large rubber trade at my new post, and I made up my mind that the occupation of the region would be for a long time to come of strictly military character. The establishment of a "factory" at this point just when the entire country was in arms against the white man-cut off from communication with the other posts save by the native paths, which were too dangerous for a small force to attempt-seemed to me as senseless as it was risky. The presence of a weak enemy among them would only have incited the natives to every effort to starve him out, as they did later at Yambata.

On the third day after our arrival the chief Kumandungu came in, followed by a slave bearing a fowl the size of a pigeon and a dog as presents for the white chief. He was but a petty chieftain of the district, the head chief having declared his intention never to make peace with the white man. A great deal of confidence was placed in Kumandungu's professions of friendship, for he it was who had warned the black sergeant, when he had abandoned his post at this place, that the natives were lying in ambush along the road it was his intention to follow; and by Kumandungu's advice the little garrison took a trail through the jungle and so avoided the ambuscade. For my part I felt convinced that the wily cannibal was only playing the spy. The Budjas had at each post one chief who remained ostensibly friendly, and in this manner kept themselves well informed as to the invaders' movements. However, as Kumandungu promised to bring in plenty of kwanga, we were content to have his friendship. 
After the post had been completed, so far as its defences were concerned, the Major, the commandant, and the two lieutenants left for Monjoa, which was only a day's march to the eastward, while I and the other company's agent were left, like two feudal barons, to "hold the fort" with fifty valiant men-at-arms. Our superior officers, however, furnished no provisions, save half-adozen tins of "embalmed" beef and one of butter, and we should have fared badly had not some of the soldiers, immediately after our arrival, killed two buffaloes, which provided us with meat for two days. Of course we were strictly teetotal, from lack of means to be otherwise. However, we consoled ourselves with the thought that provisions would arrive in a week's time, and were content, in the meanwhile, to make the best of matters.

After the departure of the column we occupied ourselves in strengthening the stockade and improving the blockhouse. The latter, built upon the top of an ant-hill which had been partly levelled for the purpose, commanded a considerable space around the post. It consisted of logs firmly embedded in the ground, above which they rose to a height of fifteen feet. Inside, twelve feet from the ground, a platform was built of logs, a rough ladder giving access through a small hole. A roof of leaves partially kept off the rain, although during one of the tornados, which blow fiercely with every rainfall, it was a matter of some difficulty to find a dry spot. In the space thus provided, measuring some twenty-five by twelve feet, we rigged up an old tent, and with the aid of a tarpaulin and our rubber blankets, constructed a small and somewhat airy apartment just large enough to hold two camp beds. As the tops of the perpendicular logs rose about three feet above the platform and the roof stretched well down on every side, leaving us only sufficient space to preserve a good view when standing upright, we were well sheltered from the sun. A door of logs, bound together with rattan, was hung in such a way that the narrow entrance which gave access from the stockade to the lower part of the tourelle could be dropped like the portcullis of a castle. Along the interior of the palisade shelters were built for the men, each of whom slept in the place assigned to him, and so, in case of an attack by day or night, we were always well prepared. In three upper corners of the blockhouse sentries were posted, while the lower part served as a guard-house. A small shelter which had 
stood outside the stockade was removed and placed within the quadrangle, and this was intended to be utilized as a kitchen and lounging-place for our "boys," whose duties at this time, however, were almost nil, seeing there was nothing to cook.

On the evening of the day our friends left us I was fortunate enough to shoot two guinea-fowl. These birds, though not very numerous, are met with all over the Congo. At Yalombo they were accustomed to roost upon the low trees bordering the clearing, and by creeping carefully along the edge of the open ground I got to within a dozen yards of them, and had no difficulty in knocking over two of their number. This was a great windfall for us, for the birds were both large and fat, and proved delicious eating.

I occupied the next two or three days, aided by some of the carriers who had remained with us as labourers, in sowing the entire space which had been cleared with maize and beans, for which, I doubt not, our Budja friends were duly grateful later on, when they gathered the crop.

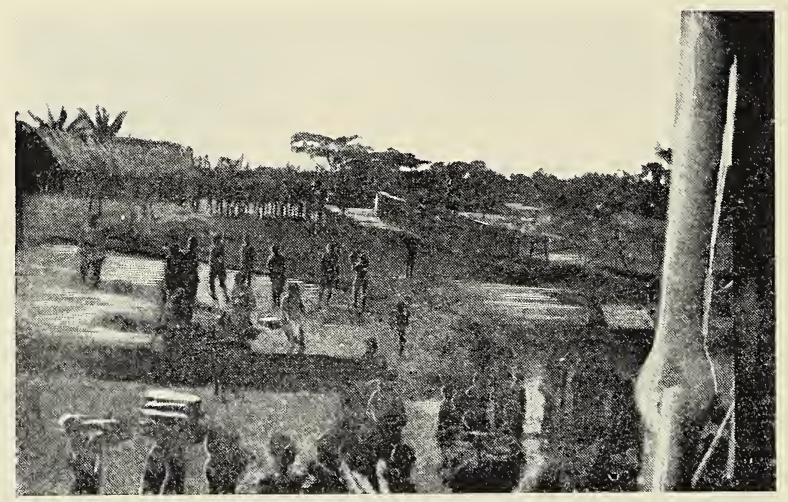




\section{CHAPTER IX.}

THE RETURN TO THE RIVER.

Our Budja Babies-An Elephant Hunt-Kumandungu as Comedian-An Intended Feast and Its Sequel-The Massacre Near Yambinga-I Act as Surgeon-Seven Tons of Human "Meat"-Yalombo Abandoned-Smallpox at Monjoa-Again at N'Dobo-The Cost of the Campaign.

ONe morning we heard an unaccustomed wailing in the bush a short distance from the post, and on investigation found that it proceeded from one of three Budja infants who had, in the confusion consequent upon the approach of our column, been lost or abandoned by their mother, and had evidently wandered about in the neighbourhood of the village until the search for food brought them quite close to the station. The soldiers carried them in, and on seeing our white skins the youngsters set up a howl that no amount of coaxing would stop. We accordingly had them placed in the guardroom with the soldiers, who gave them kwanga and soon had them quiet. Still, whenever I or my companion approached too near, the din recommenced. Later we handed the infants over to the chief Kumandungu, and very possibly they later on found their way into that dusky diplomat's cooking-pots.

We continued each day to add a little to our defence, occasionally sending out the force of labourers to forage under escort. They generally returned laden with cassava-root, which was afterwards, by a process of soaking in water and kneading, converted into kwanga.

We had been some five or six days at Yalombo, when one morning we heard a regular fusilade in the bush close to the post. On asking the soldiers what it was, they replied: "Joko, joko." ("Elephant, elephant.") 
It appeared that during the night an elephant was heard trumpeting near the post, as, indeed, quite frequently happened, and that early in the morning a party of men had crept out bent on having meat to vary the diet of kwanga. They soon came across the great brute, and opened up a hot fire on him. We heard continual shots, the sounds receding into the jungle. Taking an Albini and a pocketful of cartridges, I made off with two or three more men in the hope of catching up with the others in time to join the fun. We followed a native trail some distance until we came upon the tracks of our men. After this there was a scramble through

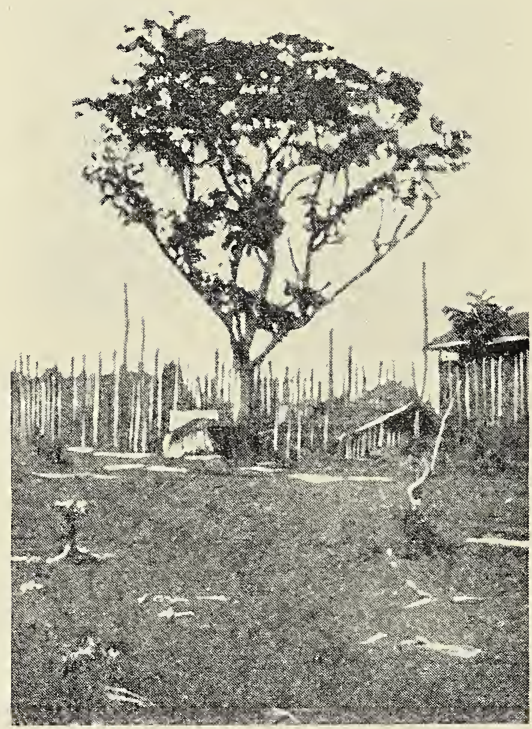

STOCKADE AND BLOCKHOUSE AT YALOMBO.

thick jungle for ten or fifteen minutes, and then we came to a muddy pool where the animal had probably first been seen, for there were many tracks of both it and the men. Through the jungle a fairly wide path had been torn by the wounded beast in its frantic rush, and we were enabled to follow rapidly, the shots ahead telling us that we were on the right path. When we finally came up with the chase the huge beast was already on his knees, and in a few minutes toppled over, but not yet dead, although he must have had over fifty bullets in him. The hunters were all around him, stationed behind the trees ready to open fire should the 
quarry show signs of reviving. I directed each of the men who came with me to fire a bullet into his head behind the ear, said to be one of the vulnerable spots. This they did, and before long the huge pachyderm, with a final flap of his trunk, expired. He was a big bull, and I secured by his capture two fine tusks, each weighing about sixty pounds, which I later handed over to the company's agent at N'Dobo, for I could not keep them, being only an employé. Moreover, all the rubber and ivory in this territory is a monopoly of the company.

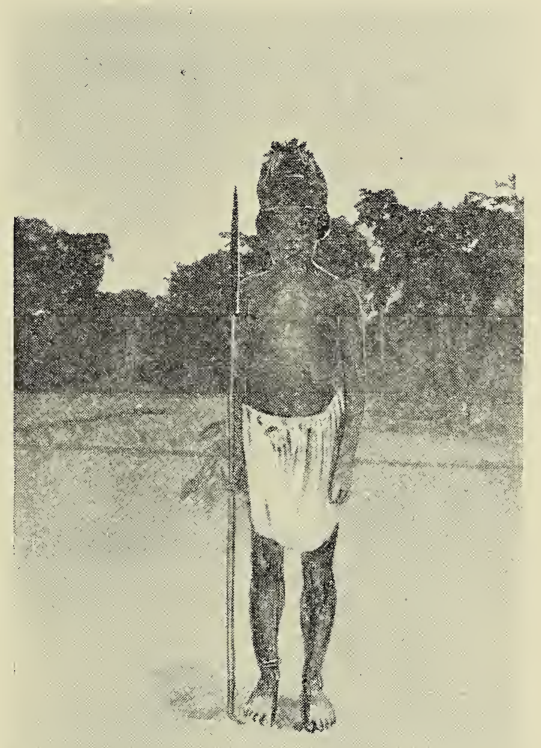

MOBANGI CHIEF.

Leaving a small guard to stand sentry over the huge pile of flesh, I returned to the post with the remainder of the men and sent them back with the labourers armed with machetes to cut up and bring in the meat, a task which occupied them until sundown. For ourselves we reserved only the heart, as the flesh is too coarse and tough for teeth accustomed to tender beef and mutton, while the remainder was distributed throughout the garrison. All night and the following day great fires were kept going, over which, laid in slices upon a platform of sticks, the meat was put to smoke. 
Thanks to this piece of good fortune we were able to keep our people in food for many days, for Kumandungu came with his folk, bringing quantities of kwanga to exchange for meat. After the division of the elephant, there remained the hide, the head, and other odd pieces. These were first exchanged for the kwanga. Every day thereafter, until our departure from Yalombo, the natives came, and, seating themselves in a row before the post, waited patiently until the corporal purchased whatever they had to sell. I had meanwhile strictly forbidden the soldiers to approach the natives, in order to avoid the possibility of disputes, for brother black never loses an opportunity to steal, or outwit another. The third day after the killing of the elephant there remained only the ears and a piece of the hide, all in an advanced state of putrefaction owing to having been left in the sun; nevertheless these people eagerly jumped at the opportunity of buying even the smallest piece. A morsel of elephant skin, nearly an inch thick and much resembling rubber in texture, would buy a large kwanga weighing two or three pounds. What would not some of our dyspeptic millionaires give to possess such stomachs as those of these men of the bush!

Every day the soldiers and labourers continued to buy kwanga with the meat they had smoked, and consequently we soon had a store of provisions sufficient for a few weeks. Indeed, our men were better off than my companion and myself, for our slender stock of European food had disappeared, and we were finally reduced to living on kwanga fried in elephant grease, a small quantity of which our cook succeeded in procuring. It was not a diet to set before any other than the Cannibal King, and we did not gormandise to any great extent upon it. My fat Belgian comrade complained bitterly of the lack of variety that characterised each day's menu. I offered him, it is true, some roast dog, for Kumandungu had succeeded in finding another cur which he thought possessed the "points" needful to grace a white man's table, but my friend had the bad taste to refuse this dish which is one essentially proper for chiefs-in that country. Just at this time, too, the guinea-fowl ceased to frequent the neighbouring bush, so that there was absolutely nothing to vary our gastronomic monotony, nor did we dare allow our men far from the post to hunt game, for we risked their lives and 
the safety of the station often enough by sending foraging parties into the plantations and in cutting poles and logs in the forest. There was, therefore, nothing left but to hope for the speedy arrival of the detachment with provisions.

One day the men announced that they had heard firing to the south, so we concluded that the force with the commandant was busy "patrolling." We had seen no natives with the exception of the chief Kumandungu and his people, but by the beating of tom-toms at night we could tell that they were not far away.

Kumandungu came regularly to "palaver" with us. $\mathrm{He}$ seemed quite intelligent in spite of his ferocious aspect, and was renowned as a great traveller among the natives, having been to Bumba, three days' journey. He recounted each day his experiences, among which the one that seemed to have made the greatest impression on his mind was the arrival of the steamer at Bumba. His illustration of how the steamer was sighted, and the noises he made to imitate the escaping steam, the whistle and paddles, were most ludicrous, and his contortions illustrative of the backing and mooring at the river-bank marked him as a comedian of the highest rank. His counterfeit of a white man riding a mule was excruciatingly funny. For this he called in the services of one of the slaves who accompanied him, making him get down on his hands and knees and mounting on his back, all the while beating him unmercifully with a stick. Kumandungu became a great favourite with us all, even the soldiers. I gave him a suit of pyjamas and the only spare hat I had, and he appeared with his people each day in this costume, of which he was prouder than he would have been of a jewelled crown.

Finally there arrived a detachment of eighty men under Lieutenant Wynants, who had commanded the police post at Mandika, bringing a quantity of provisions. He was to return immediately to Monjoa with Rabe in order to join the command of the commissaire de district, who had arrived at that place, for it was intended to march in a north-easterly direction towards the Itimbiri River, where there is a State post called Mondungu. However, my companion Rabe, in a fit of excessive zeal, persuaded Wynants to go over the ground we had covered from the village of Yambinga (where the execution of our two prisoners took place) to Yalombo in order to show the natives that the white man, with his 
guns, had nothing to fear from them. The lieutenant, ever ready to oblige his friends, consented to march towards that place, and accordingly, the next morning at daybreak, the men were mustered before the post. Twenty of the best men of our troop were selected to reinforce the detachment, which was thus increased to a total of one hundred soldiers, and to these were added some twenty carriers, cooks and boys. It was arranged that I should stay with the remaining thirty men to hold the stockade, it being the intention of the others to return on the morrow.

I had seated myself in the corner of my "tower," and was about to raise to my mouth the first spoonful of soup-the initial

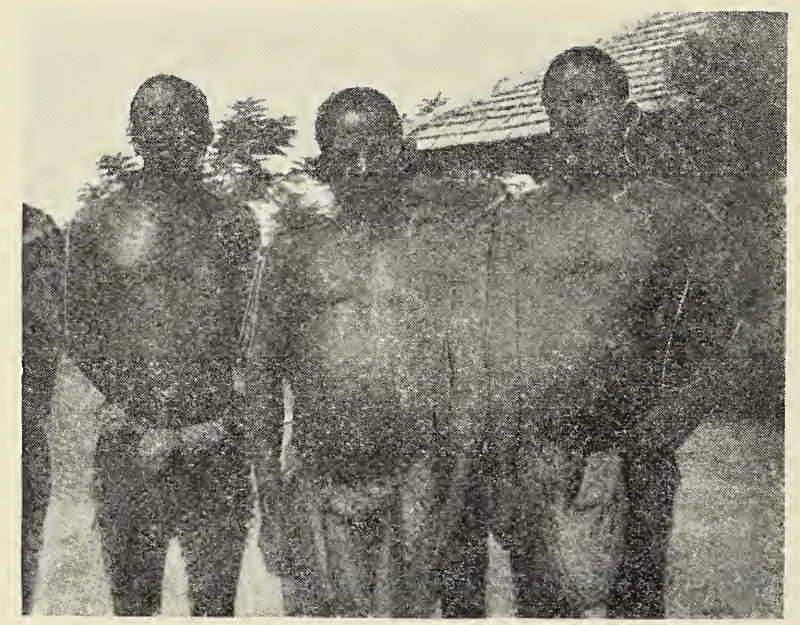

BASOKO NATIVES.

course of my mid-day meal, and intended to be succeeded by ox-tongue, tinned peas, pancakes and jam, cheese and coffee, a carefully-arranged gastronomic treat such as had not come my way for some time--when I was startled by several shots fired in rapid succession in the village road close to the post. Rising hurriedly to learn what was the cause, I perceived a soldier running towards the stockade, pausing every dozen paces to fire behind him. On perceiving that it was one of the Maganzulus who had left a few hours earlier with the column, I felt instinctively that disaster had befallen them. As the man reached the blockhouse and was brought inside the guardroom he threw himself upon the ground, 
unable to move or speak. However, after a drink of water and a few moments' rest, he recovered sufficiently to answer my questions.

His story was quickly told. The column had been marching, as usual, in hollow square with scouts ahead, and had arrived without incident at the spot where we had camped at Yambinga. As many posts of our stockade were still in the ground, the lieutenant wished to camp there; all that was needed, he thought, was to add a few new poles and slightly repair the portions destroyed. A black sergeant, however, advised him to advance a little further, where, he said, was a better camping-ground.

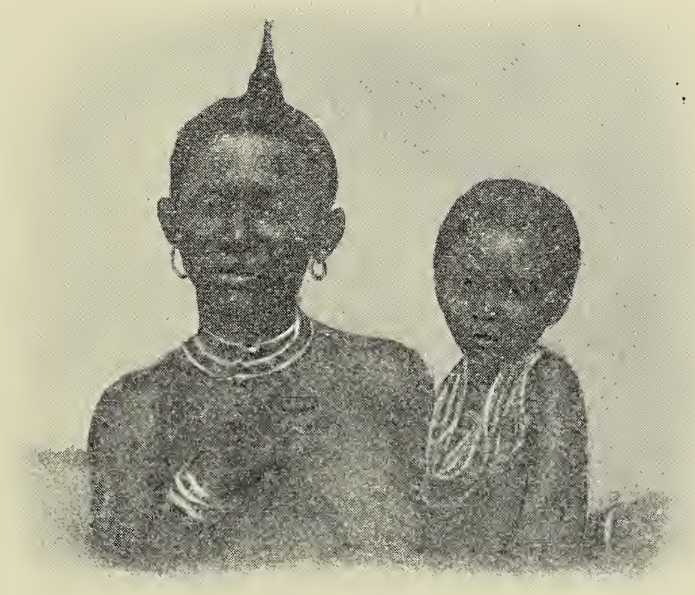

GOMBÉ WOMAN AND CHILD.

Accordingly the column moved on again, but had only just entered the space selected by the sergeant when, without a sound of warning, a great mass of Budja warriors broke from ambush, where they had no doubt lain concealed for some time, and fell upon the soldiers before the latter had even time to raise their weapons. The men of the advance-guard were able only to fire one cartridge apiece, when they were transfixed by the enemy's spears. With the exception of the Maganzulus, who formed this advance-guard, the whole column broke into a frightened mob, rushing in all directions to escape, having dropped their arms at the first sight of the enemy. In the midst of this seething mass the two white men 
were thrown down, and probably within a few moments speared to death. Hemmed in on every side, escape was impossible, and it was only owing to the fact that he had been somewhat in advance of the column that my informant succeeded, on seeing that all was lost, in running quickly into the jungle, followed by a number of the enemy, who continued the pursuit to within a few hundred yards of our palisade.

This suggested a decidedly awkward predicament. I expected every instant to see a host of warriors appear from the bush surrounding the stockade, for in their moment of triumph the Budjas, convinced that their mono was indeed strong, might essay an attack on us. Nevertheless I felt secure enough in the blockhouse, in spite of the small confidence I had in my men.

The disaster was far-reaching in its effects, for, with our best men slain and the enemy no doubt greatly elated by what must have appeared to them a brilliant victory, the task of subjugating the Budja country became more than ever impossible. Fortunately the capture of a hundred rifles and some eight or ten thousand rounds of ammunition made little difference, for the savages had no idea how to use the weapons. Had it been otherwise, we should have been speedily sent to join our unfortunate comrades, for our "fort" would not have been tenable for a moment against the rifle fire which could have been poured upon us by the enemy from the shelter of the bush. Knowing, therefore, that I could hold the place even with a few men against any number of spears, I resolved to disregard the advice of the only black corporal I had (who was most anxious to make a run for Monjoa), and remain as long as provisions held out. Besides, I thought it more dangerous to venture out at that moment, when I expected a host of warriors to be concealed in the surrounding jungle. After considering awhile I decided to send a runner to the commandant at Monjoa, advising him of what had taken place and asking him to come to my relief as soon as possible. Accordingly I selected three of the best of the labourers who, having previously been to Monjoa, were acquainted with the road, and, writing three hurried notes, charged each one to make the best of his way to the commandant, which was done with the instinct inherent in all "bush" blacks of keeping the right direction even in the densest jungle. 
Whilst my messengers were speeding away, I occupied myself in putting everything in order, so as to give the enemy a warm reception should the Budjas feel their mono strong enough to venture an attack. The entrance to the stockade I had strongly barred, leaving only enough space for one man to pass at a time.

The loss of my companions of the morning and of so many soldiers did not have a cheering effect upon me or my men, nor did my spoiled and now cold "banquet" help to enliven me. The men were naturally excited on hearing the news, but I think were somewhat reassured on seeing me apparently indifferent, an air which I jauntily assumed, but which, I am free to confess, was more politic than genuine. Having some faint hope that one at least of the two white men might have escaped, I ordered the bugler to sound various calls from time to time with a view to attracting the attention of any of the detachment who might be wandering in the jungle. Although the Maganzulu had appeared most positive that he was the sole survivor of the column, I found it hard to realize the fact.

Towards the middle of the afternoon two men arrived, both covered with spear wounds. They had succeeded in dodging the enemy by keeping their bodies bent close to the ground and rushing between the Budjas' legs, finally getting away into the bush, but not without receiving a number of spear thrusts from the thickly-massed warriors. I did the best I could for them, and had scarcely dressed their wounds when another wounded man arrived, followed soon after by a corporal and a boy-the last mentioned the only uninjured inidividual among these new arrivals. I had now all I could do to dress the wounds, many of which were very severe, especially that of the corporal, whose cheek had been traversed by a spear coming out at the neck and narrowly missing the carotid artery.

The arrival of these men excited a hope in my mind that more of them would reach the stockade under cover of the darkness, so the bugler was kept busy sounding his instrument until midnight. However, no more of the men turned up; and as it appeared that all but six out of the hundred and twenty had been killed, I concluded it was impossible for either of the two white men to have escaped. 
I passed a rather anxious night and remained awake until daybreak, for I could not trust to the sentries whom I had posted, and who, negro-like, dropped off to sleep as soon as my back was turned. I rather expected a visit from the enemy during the early morning hours, or at least to hear them in the jungle. But, as my friend Kumandungu informed me later, the victorious and hungry Budjas were busy dividing the "bag," which was certainly a larger one than any we had made. It must have taken them some time to divide the bodies, cut them up, and carry them off into their jungle retreats, although the women were probably summoned by drum from all quarters to load the baskets. Seven tons and more of human meat cut up into roasts, steaks, chops and cutlets! It was no doubt a most festive occasion

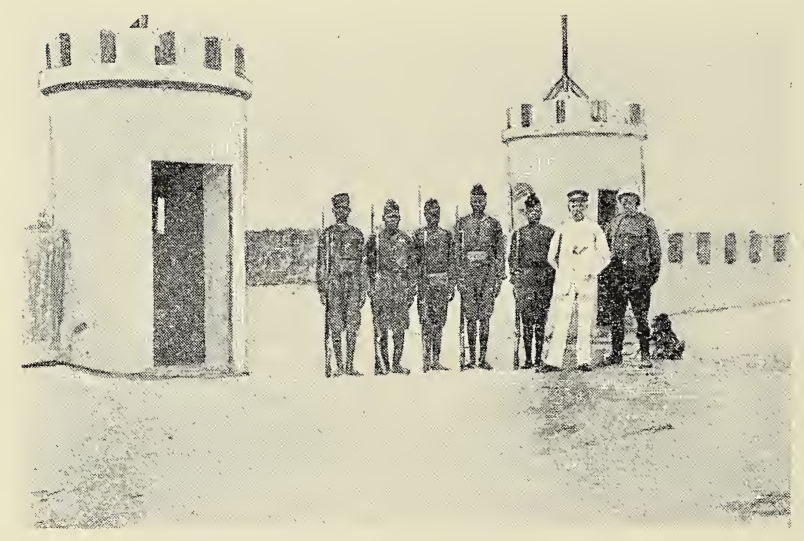

ENTRANCE TO BASOKO.

for our friends and neighbours the Budjas. I would have given much to have been able to take a snapshot of the scene, but dared not venture into the bush, where many of the enemy were no doubt sneaking, nor would I have found a single man among my valiant garrison willing to accompany me.

As a consequence of the anxiety of each to secure his share of the meat, the Budja warriors were kept busy for several days smoking it over their fires. For this we were duly thankful, for, with our forces so seriously reduced that a continuation of the campaign was out of the question, the only thing for me to do was to make good our escape from a position which, to say the least, was most precarious. 


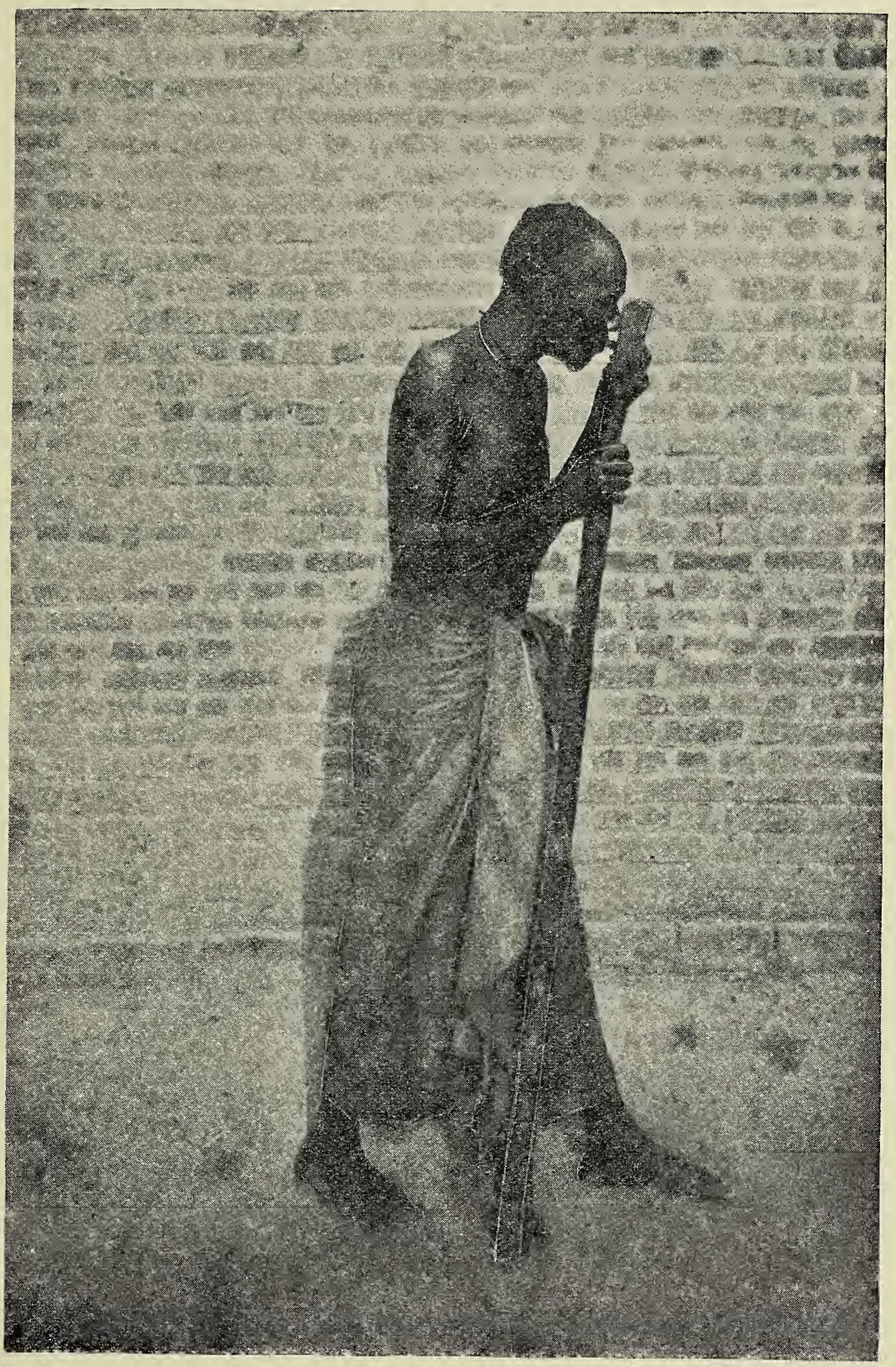

JO OF OLD BASSAM. 
During the afternoon we saw a soldier creep out from the bushes and advance towards the post. He announced the arrival of the commandant, who, he said, was on the other side of the swamp which filled the low-lying land to the east of Yalombo. Monsieur was lame and wished the hammock sent, and asked, as evidence that all was well at the stockade, that a shot should be fired. This .was done and the hammock sent, but the commandant himself soon appeared with his men, his lameness having no doubt vanished when the shot announced our safety.

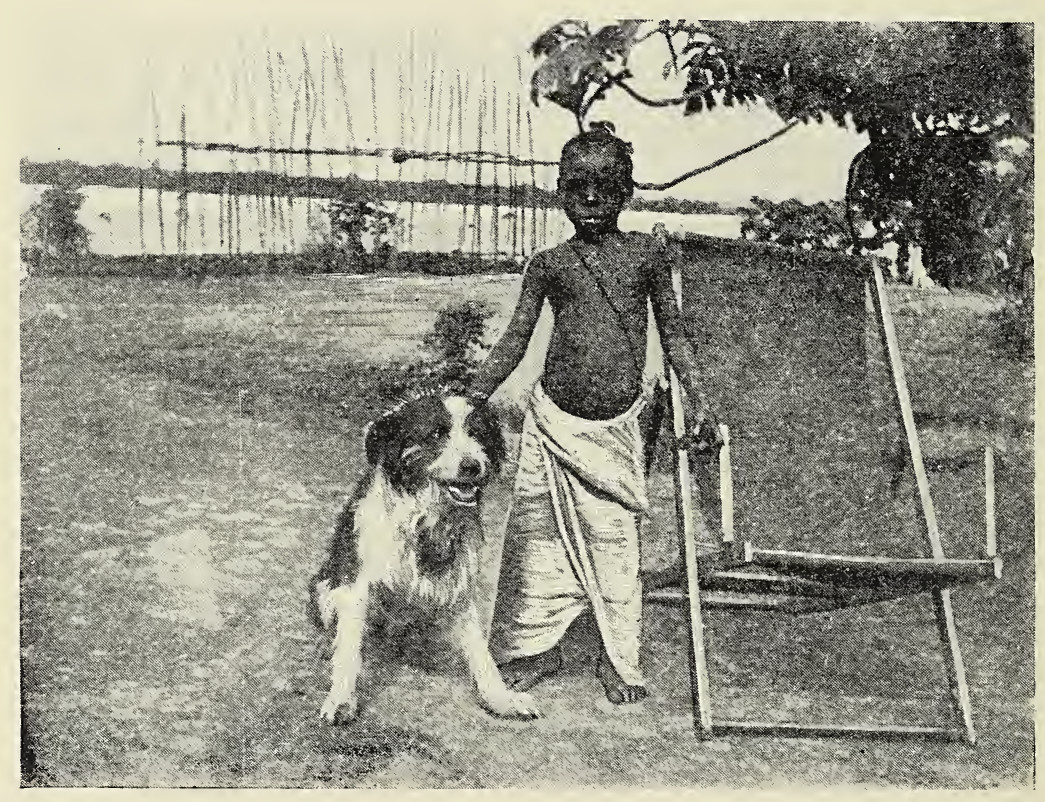

PIGMY AND SHEEP DOG.

The hitherto blustering and supercilious Belgian lieutenant was now more civil and amiable. He even condescended to listen to advice from a humble pékin like myself, who had been among cannibals long before he left his school-desk. He looked upon the loss of the best men we had as a serious blow, but said that I should nevertheless remain at Yalombo while he went off to Bangala station, or some other distant place, to look for fresh troops. I informed him that I was willing to remain as long as provisions held out, but that as soon as the last kwanga was eaten I should scurry off to some place where provisions were more 
plentiful and Budjas less numerous. He finally came to see the utter futility of keeping a white man and thirty soldiers cooped up like so many parrots in a cage, and decided to withdraw should the reply to his demand for immediate reinforcements, which he had sent by runner to the commissaire de district at Monjoa, prove unfavourable.

In two days the reply reached us. No reinforcements could be sent-not another soldier could be found-and M. le Commandant was advised to return as soon as possible to Monjoa. We therefore decided to abandon Yalombo.

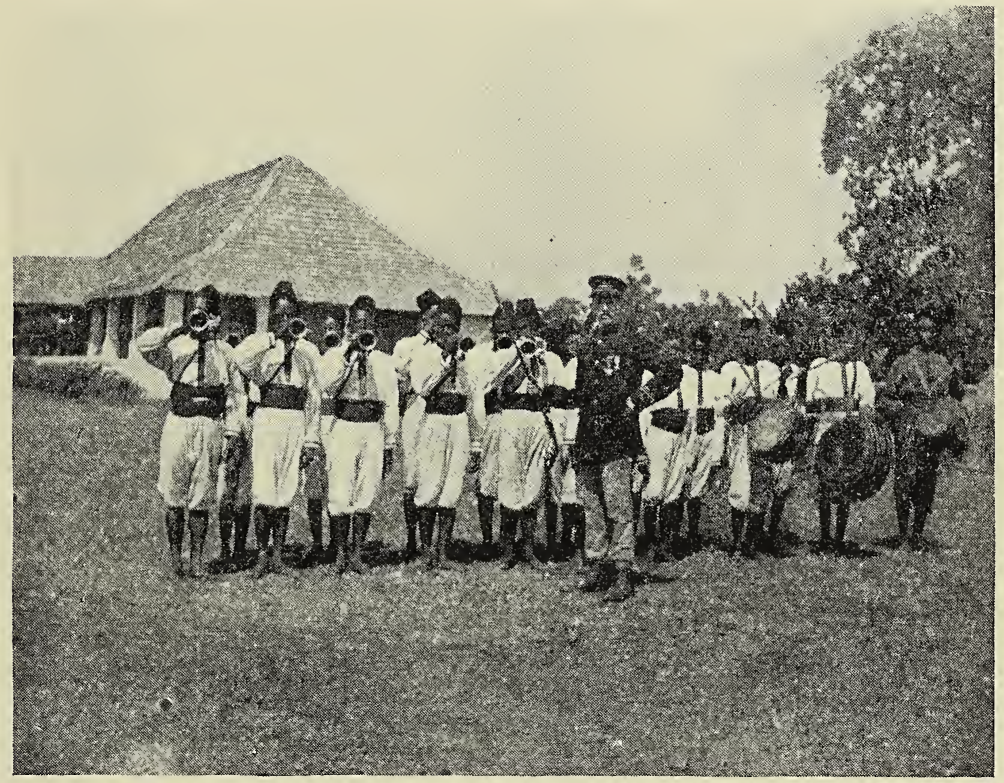

BASOKO BAND.

The next morning, while it was still dark, Kumandungu crept up to the palisade and announced that the enemy had arrived, and were in the jungle near by awaiting the break of day to attack us. At this news the commandant began to bustle about to see that everything was prepared, for he evidently did not want his corpulent body to add to the already plethoric larder of the wild men.

We waited anxiously for daylight. It came, but no Budjas with it, and we were puzzled to know whether our dusky ally was deceiving us or whether the enemy had seen that we were ready for them and had postponed their visit. 
During the day we packed all our provisions, ammunition and other valuables, not forgetting the two tusks, and made everything ready for our departure. As the earliest faint rays of light began to steal over the tops of the trees we filed out of the fort, quietly and without beat of drum or sound of bugle, and made rapidly for a small bush path which, avoiding the general line of villages, passed through many swamps and thick jungle towards Monjoa. Not a word was spoken, and the rapidity of the march kept me in a constant state of breathlessness, for the soldiers seemed to have winged heels, the commandant, however, who was at the head, setting the pace. We passed some small clearings and groups of huts, but saw few natives, although several were shot by the scouts. After a few hours' quick march we arrived at Monjoa, where we were received by the commissaire de district and the company's agent in charge of the factory.

Thus was the post of Yalombo abandoned. It should never have been established, for, being far from any navigable river, it was entirely at the mercy of the enemy, who could easily enough have cut off all communication with the outside. It would merely have been necessary for him to abridge our supply of kwanga to force us to abandon the place. All these considerations, of course, should have been carefully weighed before the decision to establish a "factory" was arrived at; as a matter of fact they never, apparently, entered the minds of the two military heroes who had the direction of affairs.

Kumandungu, dressed in his pyjamas, came to Monjoa a few days later and illustrated, in his usual comic manner, how astonished he had been when he arrived at the palisade and found nothing but empty tins. He received not a few presents, and promised to come often with his people to sell kwanga, but I never saw him again.

The natives of the neighbourhood had been quite friendly before the revolt of Majumba; but the agent of the company, an ex-pastrycook, having become displeased with the chief for his neglect to carry out some orders, seized him, and, taking him into an empty store-room, proceeded to pummel him until he cried for mercy. This strange treatment offended the chief as much as it must have astonished him, and, vowing vengeance, he came no more. The incident may be quoted as another example of Belgian tactlessness in dealing with the natives, who at this place had 
never seen a white man before the arrival of the ex-fabricator of tarts and cakes. One inferior chief, however, still remained friendly, and came daily with half-a-dozen women laden with cassava leaves for sale. I saw at once that he was playing a rôle identical with that which our friend Kumandungu had enacted so admirably at Yalombo, and he, no doubt, kept his brother chiefs well informed of our movements.

The day after our arrival at Monjoa the commissaire de district and the commandant decided to go to Bumba, while I received orders to remain with the "troops" at Monjoa until further instructions were sent. Major Lothaire, I learned, had departed several days before for Mobeka.

I found the place afflicted with an epidemic of smallpox, and each day one or two of the soldiers were taken ill. All we could do for them was to erect rude shelters in the jungle close to the post. The labourers also became infected, and we soon had a score of patients to look after. It was far from pleasant being so near the "cases," but I am of opinion that in this climate the disease rarely attacks white men. The epidemic had been raging throughout the Congo for over a year, and I had heard of only two Europeans who had contracted the malady. We subsequently learned that the disease was raging among the Budjas. It had no doubt been introduced by some of our force carrying the germs in their clothing. Moreover, one of my own men had died of smallpox at Yalombo and had been buried beside the post; and the corpse, according to Kumandungu, was disinterred some days later and-devoured. This surely was sufficient to inoculate the tribe and explain the subsequent mortality.

I was not sorry some days later to receive orders to march my men to N'Dobo, and we all set off rejoicing in the prospect of once more beholding the broad placid waters of the mighty Congo. The march lasted two days, during which nothing worthy of note occurred. We passed a few isolated villages in ashes, about which lay many putrefying corpses, and made some prisoners (I had strictly forbidden the men to shoot), whom I promptly released. As we approached the river we passed through many little grassy plains, and near Ebonda, a fishing village on the river-bank, we 
had the good fortune to kill three buffaloes, I bagging one with my Winchester. This lucky find gave all my people an ample supply of food.

Thus terminated, so far as I personally was concerned, active operations against the Budjas. Not so, however, my connection with their country, for within a short time I was again on its confines, destined to remain for no fewer than three months a beleaguered "advance-guard of civilization." Up to the present we had undergone six weeks of painful marching and had killed over nine hundred natives, men, women, and children, according to the

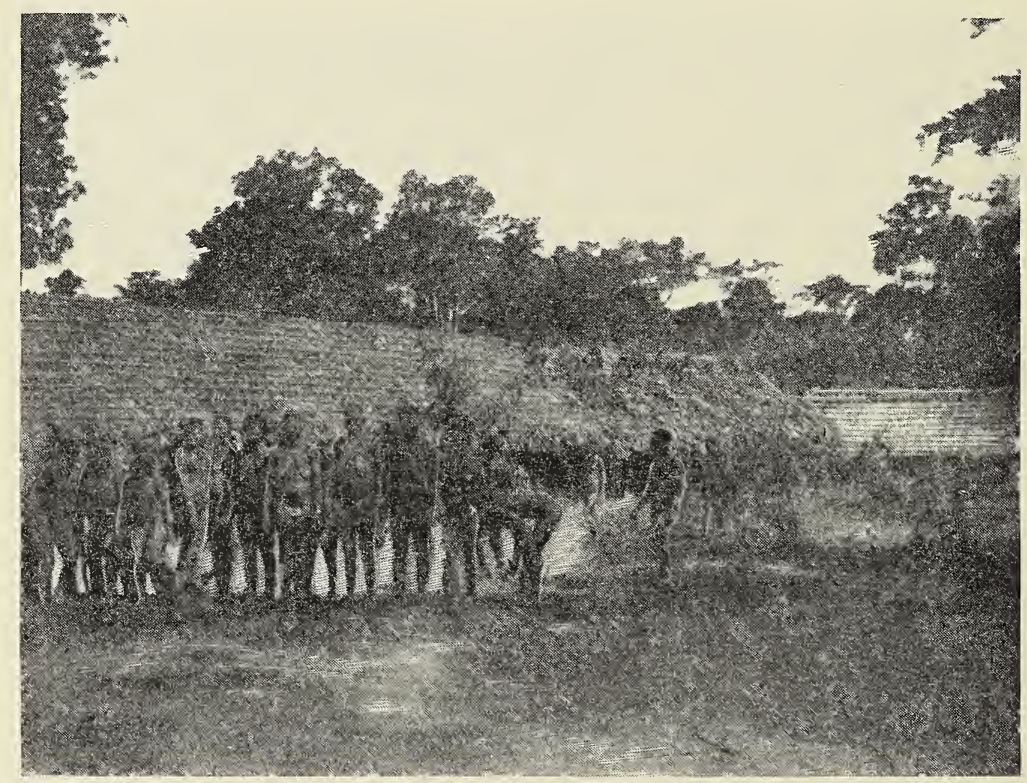

WORKWOMEN IN BRICK SHEDS, BASOKO.

account kept by Lieutenant Gilson; but, on the other hand, more than half our force had been destroyed by the enemy or by disease, and our prestige among the Budjas fatally affected. Had we succeeded, it would have been a "big thing" for the company, adding fully twenty tons of rubber to the monthly crop. The Budjas, moreover, might have become our docile slaves, to be "tagged" and flogged with impunity until the arrival of a moment opportune for them to fall upon and massacre another column. 
It was many a long day since the cannibals had had such a plentiful supply of "meat" as we left behind us. May they long live to enjoy the memory of it! I wish them no ill, but hope that they may keep their wretched country, for I am sure no white man need grudge it them.

At Ebonda the company's steamer picked us up and took us to N'Dobo, where I immediately turned the command over to the commandant and took to my bed, for my stomach, in revenge for the manner I had been compelled to abuse it during the previous six weeks, rebelled and kept me confined to my room for three

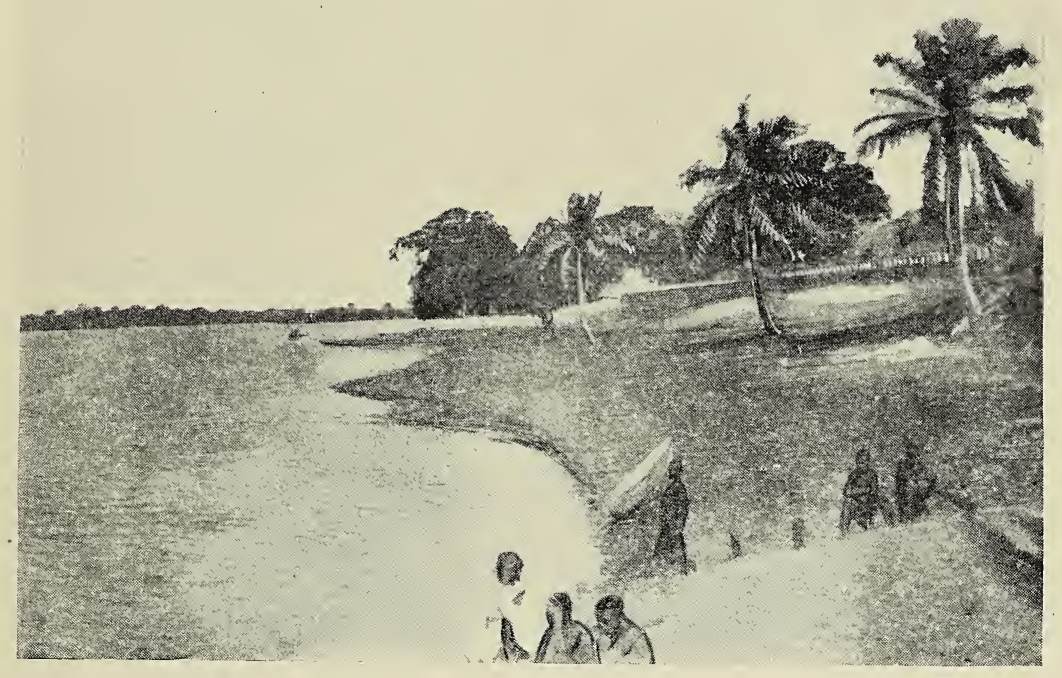

BASOKO BEACH.

weeks on a diet of milkless and sugarless tea, with but an occasional piece of toast.

At the end of this time, although I was so weak that I could not walk, M. the Belgian commandant said that I must "get out" and, with what remained of my platoon, travel over the same villainous road as before. Eventually I started to rejoin the column at Baiengi, a post in the interior one day's journey from N'Dobo by water, but found myself quite incapable of proceeding further; so the commandant finally left me in peace, though 
reluctantly. He seemed most anxious to have me as his second in command, but I failed to see in this any great compliment, for he knew as well as I that ninety-nine of every hundred of his countrymen in the Congo are arrant cowards. He then arranged for me to go down river to Mobeka, and I returned to N'Dobo, not altogether dissatisfied with the turn of events.

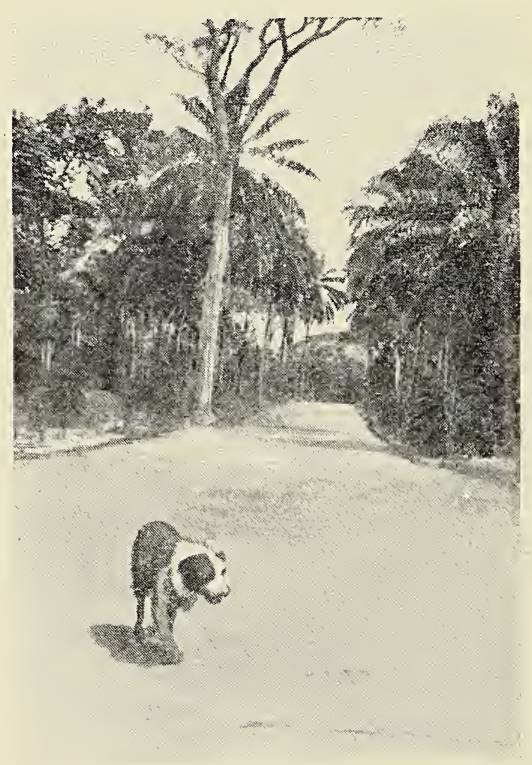




\section{CHAPTER X. \\ BELEAGUERED IN MONJOA.}

My "Temporary" Command-The Commissariat Question-A Weary and Wearing Life-A Loquacious Garrison-Another Expedition Against the Budjas-My Soldiers Conspire to Kill Me-What the Expedition Achieved-Moray as Accuser -The "Commissaire Royal"-Belgian Promises-The Attack on the Chef de Zone-Yamikele's Visit and Pleasant Intention-I Decide to Abandon the PostA Sensational Dénouement-The End of My Outfit.

A DAY or two later, just as I was about to embark on the steamer bound for Mobeka-preparatory to a journey up the Mongalla River for the purpose of taking over a station called Likimi, where it was intended, or hoped, to make large plantations of rubber-vine-the commandant reappeared, with an urgent request that I would modify my arrangements and, for a time at least, take charge of the post of Monjoa. It seemed that the brave Belge hitherto in command, and whom it was proposed I should replace, had become panic-stricken on hearing of a threatened Budja attack, and declared his intention to forthwith abandon the post with all his men unless he were immediately superseded. Under these circumstances I could not well refuse the call made upon me, especially as no march was involved-the route to Monjoa being by canoe up a creek called the Malua-and the commandant undertook to send up another agent to relieve me within a very few days. However, we had no sooner reached the station than the commandant begged me to remain permanently. This I refused, but promised that I would stay a month or more if necessary.

This was the understanding when the commandant left me for the interior on a mission to reinforce and provision some posts then besieged by the natives. No one, of course, arrived 
to relieve me as had been arranged; so at Monjoa I remained with a band of thirty black "soldiers," holding the fort on a diet of rice, and not too much of that. I found the commissariat question pretty much as it was when I had the honour of serving the "State"; in most of the Government posts, however, there was usually something in the way of fresh provisions (fowls, eggs, goats, sweet potatoes, \&c.), whereas here, in the Mongalla region, these were almost unheard-of luxuries. At Monjoa I could not always obtain a root of cassava, which at least can be had in every other part of the country. The Mongalla region is the

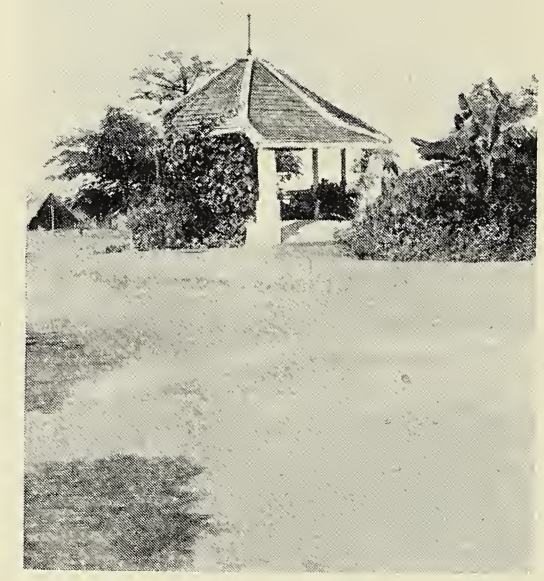

BASOKO.

poorest and most savage part of Africa I have yet seen, but it might have been flowing with milk and honey judging from the unconcern of the company's directors for the comfort and even lives of their employés.

A few weeks after my appointment to Monjoa, having in the meantime written more than once to complain of the commissariat arrangements, I went down to N'Dobo to personally insist upon some better understanding on the subject. This action was so far successful as to procure for me-I took good care to act as my 
own transport agent-my so-called six months' supply of European provisions, all packed in three small cases. For the edification of my readers, especially those of the gentle sex accustomed to the responsibilities of house-keeping, I detail the following items from the list:-1 tin of herrings, 1 bottle of table salt, 1 tin of hard biscuits, 5 packets of matches (which would not ignite on the box or elsewhere), half a ham, half a Dutch cheese, 4 tins of condensed milk, 4 lbs. of sugar, 1 half-bottle of cognac, and 2 bottles of St. Julien. Possibly some of the company's employés, ex-Belgian peasants, imagined that they were splendidly fed; but I confess

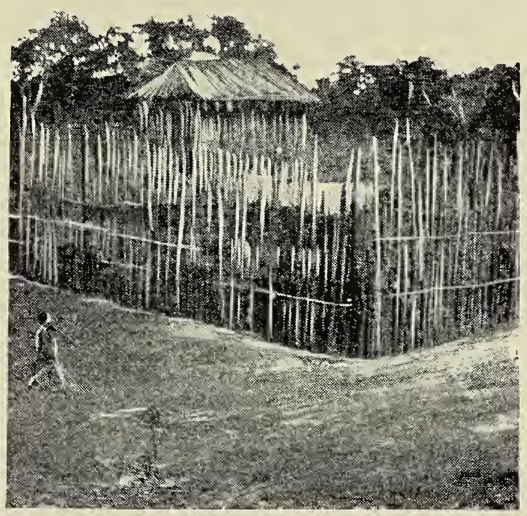

MONJOA.

that my six months' allowance suggested little in the way of self-indulgence, especially as I knew there was scant prospect of obtaining any fresh provisions wherewith to eke it out. Around Monjoa it seemed impossible to raise any vegetables on account of the myriads of insects, which devoured the young shoots the instant they appeared above the ground. Such a thing as fruit is practically unheard of in this region; even the pineapple, so common in tropical countries, is conspicuous by its absence. A curse appeared to rest upon the land; Nature had clothed the soil 
with a covering of green, but beneath the pleasing prospect she hid all that is worst in her domain. The general surroundings were savage and vicious, especially man.

I will endeavour to describe my manner of life at Monjoa, so that in after years I may read over my experiences and rejoice that I am no longer there. To begin with, I was caged up like a parrot in a kind of fort or stockade of logs and sticks, and provided with a watch-tower and blockhouse. I was commandant-in-chief of thirty savages, here called "soldiers," and also had under my watchful eye three decidedly non-domesticated "domestiques," upon whom it was necessary to practise football at least once a day, and twenty other non-military cannibals, quite recently lassoed in the jungle, and who had been sent to the station to do whatever work the white chief might think them capable of performing-in other words, nothing.

The great charm, however, of this station was my white "assistant," whose part of the show was to "assist" me to dispose of its always scanty stock of provender, which he did in a fashion decidedly unconventional. I never understood what induced the commandant to send this man to Monjoa, where certainly he could be of no earthly use. If the idea was to make my duties as disagreeable as possible, then great success attended the experiment, for I would rather have been alone with the blacks than have a necessarily uncongenial white dependent loafing around, doing nothing, and without inclination or ability to work. I was not even sure of his utility had the Budjas made up their minds to attack us. It was, therefore, quite without a sense of personal bereavement that I mentally thanked the chef de zone, a few weeks later, for carrying away my unprized aide.

However, to continue my story. I rose early and held a muster of all hands, after which I set the men at such work as could be attempted without endangering their lives. As a matter of fact, it was usually impossible to go a hundred yards from the gate of the stockade without running the risk of having a spear plunged into one; and several people belonging to the post were killed or wounded in this way because they would persist in wandering outside the fort against my strict orders to the contrary. Moreover, we never knew what it was to feel secure against a Budja attack. 
Whenever I sent out the labourers to cut posts and sticks for building purposes, an escort of soldiers accompanied them. The former went into the bush with a machete in one hand and a spear in the other, while the soldiers moved ahead, prepared to shoot if any Budja appeared in sight, or to bolt, as the case might be. Occasionally the Budjas arrived in bands, showed themselves just without the belt of heavy forest which encircled the fort, indulged in a kind of war dance, and shook their spears at us. We, on the other hand, assembled on the top of the blockhouse and fired a volley, whereupon the enemy retreated with alacrity. It must not, however, be assumed that the Budjas are cowardly; they are far from that, and, being both numerous and ferocious, I at least always held them in wholesome respect.

The following is one of the little incidents of life at Monjoa which occurred occasionally to vary the general monotony. On the morning of the 30 th of June, I sent out twenty labourers, with an escort of twenty soldiers, to cut sticks in the bush. As the best wood had now disappeared from the neighbourhood of the fort, it was necessary for them to go a short distance by canoe. They then returned with the wood they had gathered to a spot whence a path led from the river to the fort, a matter of some two hundred yards. As they were unloading the wood, a party of soldiers whom I had sent to forage along the creek shot a buffalo, and the labourers rushed off to cut him up and help to bring in the meat. This done, I sent them back for the poles and sticks which they had left lying by the river-bank. Suddenly I heard a terrific yelling, and saw the men tumbling over one another in their hurry to reach the fort. It appeared that the soldiers, instead of keeping with them, had found the neighbourhood of the newly-killed buffalo too fascinating, with the result that three labourers were speared by a band of roving warriors, one of them being found on the following day minus a leg and an arm.

I found, about this time, that the small stock of palm oil with which the station had been supplied was exhausted. Many days passed before I could obtain from N'Dobo a fresh supply, and I experienced considerable inconvenience as a result. My correspondence was, of course, very limited both as regards the receipt and despatch of letters, and I was always thankful when some of the bundles of newspapers sent to me by friends in England and 
America reached the hands for which they were intended. I endeavoured, as a general rule, to devote at least a portion of my evenings to this intermittent supply of literature, but the pleasure was usually a painful one and promptly abandoned. Thousands of mosquitoes and a score or more varieties of equally objectionable insects made miserable my attempts at comfort, and soon drove me to the shelter of my netting. Moreover, the palisade was so small

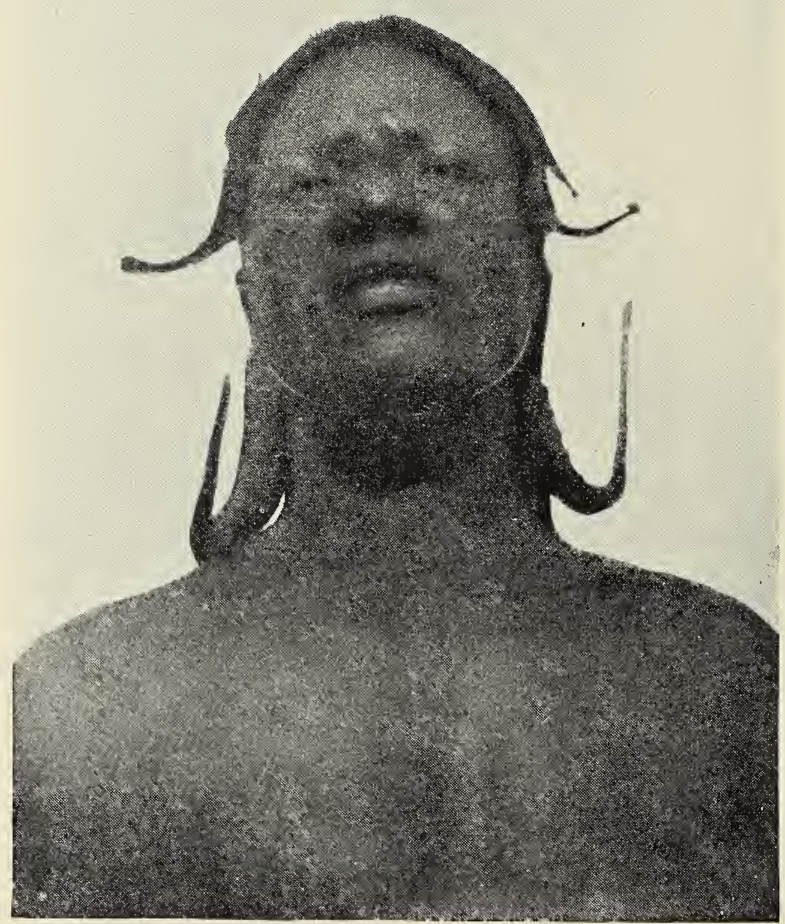

GOMBÉ FROM INTERIOR, ARUWIMI DISTRICT.

that I was never more than ten yards from my chattering, yelling, malodorous gang of gallant soldiery. I only put up with the nuisance because we were always in a state of siege, and any attempt to remove or enlarge the fort under such circumstances would have been an invitation to useless loss of life. Many of my readers have probably heard a gang of Chinese chatter, say, after a police raid in Chinatown, San Francisco, or a shooting 
affray in a mining camp. Each is a quaint experience, but a mutes' procession compared to a Congolese palaver. With the blacks in Central Africa it is cackle, cackle, cackle all day long, each man yelling at the same time as if all the others were deaf as posts. Sometimes at Monjoa my men carried their discussions into the night also, with the result that I seized a heavy club I kept handy for the purpose, and hit the first debater I could reach. Then they all ran behind their houses and hid, but talked no more. I had hard work trying to instil into their brains the necessity of silence at night, especially when there was no moon, so that the sentries might hear if an enemy approached the fort. It was only after

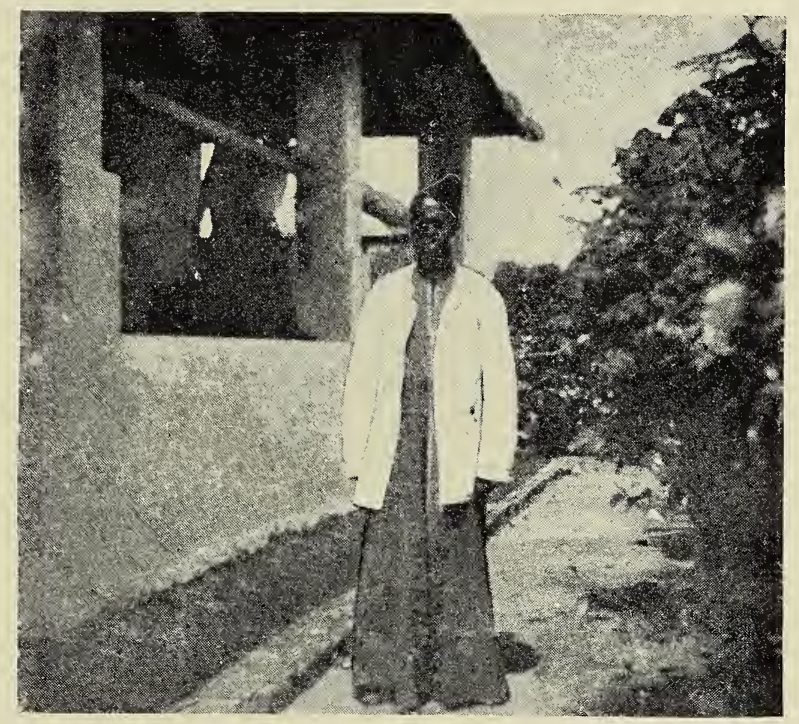

ARABISED NATIVE.

many lessons, expounded with the aid of the club, that they showed themselves at all qualified to grasp the sense of my tactics.

Early in July I received notice that the commissaire de district was shortly coming up country to personally take command of an "important" expedition which had been organised to "crush" the Budjas. A formidable-looking document was at the same time forwarded, stating that the entire region occupied by this tribe had been placed under martial law, and I was instructed to post this prominently in the Monjoa "factory," so that all people might read and take warning. The authorities could not, 
of course, be expected to know that, except myself and my "assistant," there was not a soul within thirty miles of Monjoa who could read or write. The chef de zone, an official of the company who also acted as a sort of district manager, had previously unofficially informed me that in ten days or thereabouts I would hear the crack of rifles around the post; but this notification he modified about a week later, in a letter from N'Dobo, to the effect that the commandant and other officers had gone down river to collect the remainder of the soldiers needed, and other whites. He also asked me to remain at Monjoa for an indefinite period, to which arrangement I, of course, offered a protest, at the same time consenting to leave the matter of my future movements to the determination of higher officials.

For weeks I awaited my long and oft-promised visitors, but the sun went down many times on the old monotonous round before the much-vaunted rifle-cracks were heard. It was a weary and wearing life, cooped up in a little fort, with no other companions than a few uninteresting savages, constantly expecting an attack which never came but was over and again threatened, feeling oneself the person to whom all eyes turned at the first whisper of danger, but with nothing to do more useful or exciting than a small, uncertain amount of cooking for myself, and the practically constant supervision of my flimsy defences and not too reliable allies. Often I wished the Budjas as smart as they are savage; had they been so, they would at least have made a steady effort to drive us out of the country. At the time of which I write they had in their hands some hundred and fifty breech-loaders and perhaps ten thousand cartridges, captured at various times from the State troops and company's auxiliaries; but, fortunately for the Belgians, they buried these prizes in the bush and continued to trust to their spears and shields. Even as it was, N'Dobo, the principal station of the region, had already been twice attacked by the Gombés. The latter, however, less numerous and warlike than the Budjas, had been easily scared away. Yet the very fact of such an important post having been menaced was full of significance. The entire region of the Budjas, a country about onefourth the size of Belgium, was in arms against the white man, and I, for one, never doubted that considerably more than five hundred slave-soldiers would be needed to bring the people to that 
blissful state of mind-a longing to gather rubber and "sell" it to the company at the latter's price.

I was experiencing so much difficulty early in July in obtaining supplies for my garrison, and the attitude of the Budjas outside appeared so threatening, that I decided to reduce, as far as possible, my non-fighting strength. I accordingly sent all my labourers down to N'Dobo, which left me only thirty mouths to fill; and, as soon afterwards I received some 2,000 lbs. of rice to serve as reserve stock, I felt more confident of my position. My soldiers also, as the result of constant drilling, appeared about as efficient as they were ever likely to be; and I had taught some of them to shoot fairly straight, which certainly was not in their power when I took over the command. Their capacity for edibles was not, however, sensibly affected by the acquisition of soldierlike qualities. Each of them, at 6 a.m., disposed of considerable quantities of kwanga and rice, but within three hours he was ready for more. I let them have as much food as was good for them, but every day they begged for additional allowances, until at last I fairly frightened them with the threat that the next grumbler would be shot and boiled down to make much-needed oil for my lamp. Soon after this, I received a reinforcement (which I neither needed nor had asked for) of ten more soldiers; and it is probable that the oil-making story was repeated to the new arrivals with considerable "embroidery," for they always appeared well satisfied with their rations.

Pending the arrival of the long-advertised expedition, which I was informed would consist of ten whites and five hundred soldiers, I kept my garrison fairly busy preparing for its reception, building an additional palisade along two sides of the station and constructing shelters within it. Just after the completion of this work a great row occurred between the two races, Abarambos and Bangalas, who composed the bulk of my force. The former were the more numerous, being in the proportion of twenty-six to ten, and they found, on the evening of the 20th of August, an apparently convincing pretext to pounce upon their rivals. The result was a general scrimmage, in which the Bangalas were naturally getting the worst of it when I appeared upon the scene, club in hand. To stop the noise, it being a dark night when perfect order in the camp was desirable, I drove the combatants to their houses; and then, 
notwithstanding a good deal of loud talking, of which I took no notice, I thought the trouble was over. This, however, was not the case. About half-an-hour later the corporal came across with the pleasing information that the men were conspiring to kill me. In a loud tone I questioned him as to the people who were talking thus, and he mentioned one of the Abarambos, who, hearing his name, at once appeared, followed by the others. I asked them, with a great assumption of anger and pained surprise, who it was that wanted to kill me, and said that he should go for his gun and try to do so. Of course they all denied any knowledge of such a plot or desire, but I am convinced that there was more than a little truth in the story, for I noticed in their talk after the row a threatening tone. Unfortunately my acquaintance with the Bangala language was somewhat elementary, but one of my boys told me in Swahili what had been said. I dismissed them

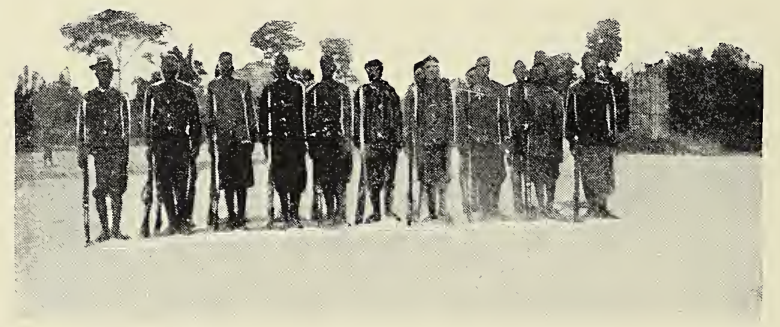

A GROUP OF SOLDIERS.

all to their houses, with the remark that they were evidently very foolish people, and that the next time I heard of any such talk I should myself begin the shooting. Somehow or other the incident made little impression upon me, although certainly it suggested a more lively time than I had been experiencing of late-with the Budjas on the outside of the stockade waiting for a chance of cutting me into "meat," and my friendly savages within thirsting for my blood.

On the following day, it so happened, there arrived at Monjoa the advance-guard of the expedition which had recently traversed the villainous road over which I had journeyed with Major Lothaire a few months earlier. This was its most notable, indeed, single achievement, for it did not even succeed in its first objective, the proposed re-establishment of the post at Yambata, which had been 


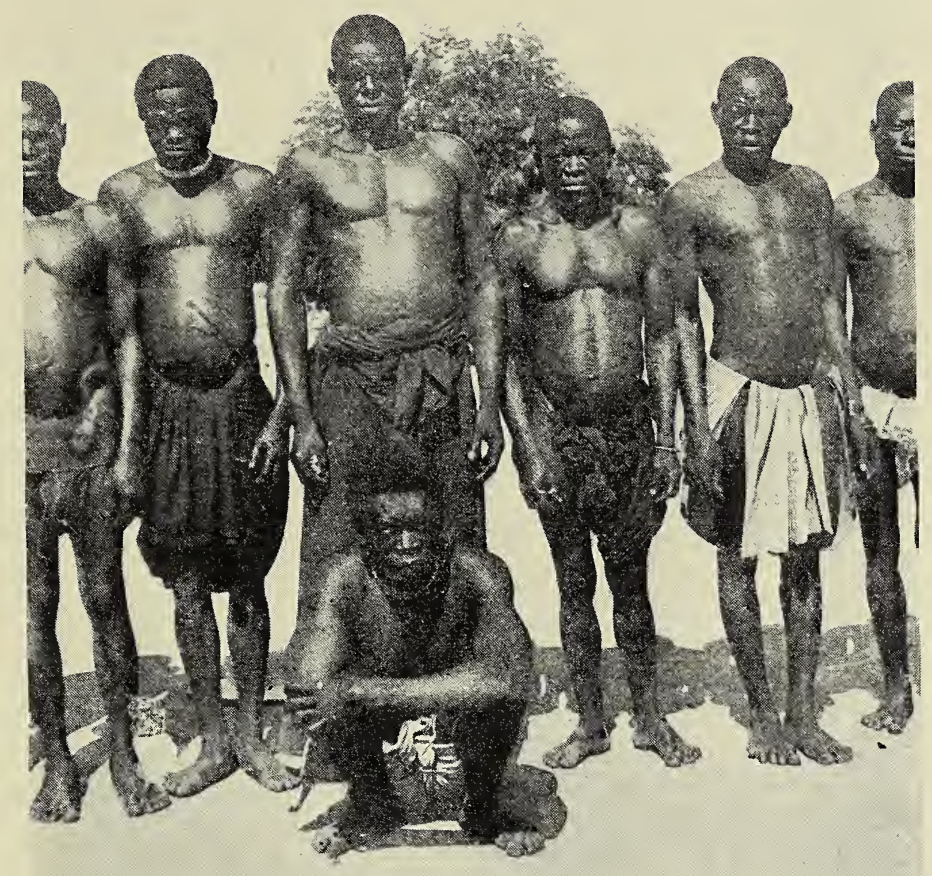

BOSCHOBERRI AND SUB-CHIEFS. 
abandoned after two months' siege and famine, but really because of the supineness of the State authorities. The story of this place may be regarded as typical of Congolese administration. Officialism bitterly complains if agents do not hurry up and put up posts, and then, when the work is done, the whole thing is abandoned or the original plans are completely revolutionized. The authorities never allow one enterprise to be completed before commencing another, more showy but probably not a jot more useful than the first, and always with the traditional amount of formality-one official writes to his immediate superior, the latter follows suit, and so on through the long list up to the GovernorGeneral.

I could not gather, even from the white officers who took part in it, any evidence that the expedition would secure for the company its heart's desire - the practical enslavement of the Budjas and their condemnation to unceasing labour in rubbermaking. Low as their intelligence is, the Budjas recognised that if they gave way they would forfeit their last shred of liberty. That they were not yet prepared for this was proved by an attempted ambuscade near Yalombo, my former post, which, very fortunately for the expedition, was discovered in good time. So sure were the enemy of surprising and killing the entire force that they had women close at hand with baskets ready to carry off the " meat," and one of these creatures, during the attack, was struck by a stray bullet and killed. The fact that the commander of the expedition showed a keener inclination for peace than for war went far to lower us in the estimation of the natives, who always judge others as they would themselves; and, perhaps with some justification, attributed to fear the present attitude of the invaders. It would certainly have been better-having once opened the campaign - to have subjugated the Budjas by force of arms and then, when they sued for peace, justly treated them. As it was, they felt more than ever confident of themselves, and the inevitable end was an enforced abandonment of the entire region, at least for a time. Even our own soldiers were adversely affected; the commissaire de district, they said, had gone up country to wage war and ended by asking them to make peace. In favour of the latter they had no sentimental weakness, and they very decidedly objected to be deprived of the promised luxury of pillage-the 
whole thing, as they put it, was "all a big lie" (lokuta). The Budjas, for their part, and I cannot blame them, want neither the white man nor his trashy goods; they certainly will not work for either if they can help it-they would much rather eat the former and his miserable following of slaves. Eight Belgians and three hundred "soldiers" had been killed in this region within a year preceding this last expedition, yet the State still clung to the belief that mere displays of "force" would suffice to bring the country under the rubber régime.

With the advance-guard of the expedition-the latter I now found to consist of only eight whites and 320 soldiers-came the chef de zone and the agent who formerly had charge of the now abandoned factory at Yambata. The main body had been left at Yamikele, three hours' march to the west of Monjoa, where it was proposed to tarry until the chief of Yamikele brought in his submission. M. van Eyck only remained one night at my station, being evidently very anxious to push on to Bumba, where a judicial official, described as the Substitut du Procureur de l'Etat, was at that time installed, presumably for the purpose of opening an investigation into the since notorious atrocities in the Mongalla concession. Together with Major Lothaire and others, the chef de zone had been accused by an ex-agent of the Société Anversoise of various horrible outrages, and he now wished to discover whether any charge had been officially lodged against him. The agent in question, a Belgian named Moray, whom I was subsequently not sorry to see lodged in the gaol at Boma, had recently been indicted before the court at Bangala for having killed in cold blood a native chief. This man, outwardly at least, remained loyal to the whites after all the other people of the neighbourhood had betaken themselves to the jungle. He one morning came to the post of Mandika, of which Moray was in charge, and the agent at once, without provocation or word of warning, took up his rifle and shot him.

There was also, within easy distance of the Mongalla country, at the period of which I write, a somewhat mysterious dignitary, a major in the Belgian army, and-if one might judge from the tremendous awe which even mention of his name inspired among State officials, great and little - an especial protégé of the Sovereign. He was entitled the "Commissaire Royal," and it . 
seemed that his particular mission was to scold, fine, and dismiss everybody in the country. He was certainly a person of quite eccentric ideas, and played havoc with the time-honoured customs of the river. One of his notions was that he was "Royal" without the "Commissaire," for he never by any chance addressed the smaller fry unless to inform them that they were fined so many days' pay. The Commissaire Royal was coming into the interior, so they said, when the news reached him that $M$. Lothaire had lost half his men and two whites, and that his own chance of being grilled over a hardwood fire were quite first-class. Thereupon he

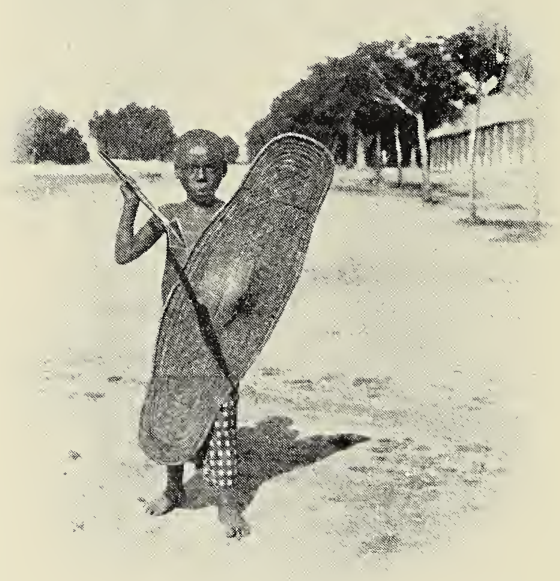

PIGMY.

reconsidered his plans, decided that his august presence was much needed on the river, and accordingly was so conscientious that he never, when travelling, could be persuaded to quit the steamer.

On August 23rd the main body of the expeditionary force arrived at Monjoa. I found all the white men with the commissaire de district strangers to me, for they had, with few exceptions, been drawn from the Welle district. It appeared that the officers of the Bangala region, on learning that their services might be required against the formidable Budjas, discovered with one accord that they were afflicted with various grievous maladies. The commis- 
saire was accompanied to my station by the chief of Yamikele, who had ostensibly submitted to the authorities, but was, I had not the least doubt, playing an old-time trick. He had most probably been compelled to feign submission by the clamour of his people, who, seeing their plantations eaten up by the soldiers, had resorted to a very favourite expedient for ridding their country of most unwelcome guests. They knew that as soon as peace was declared the white man would move away to another place.

The commissaire only remained at my post a few minutesjust long enough to enable him to give the Yamikele chief some

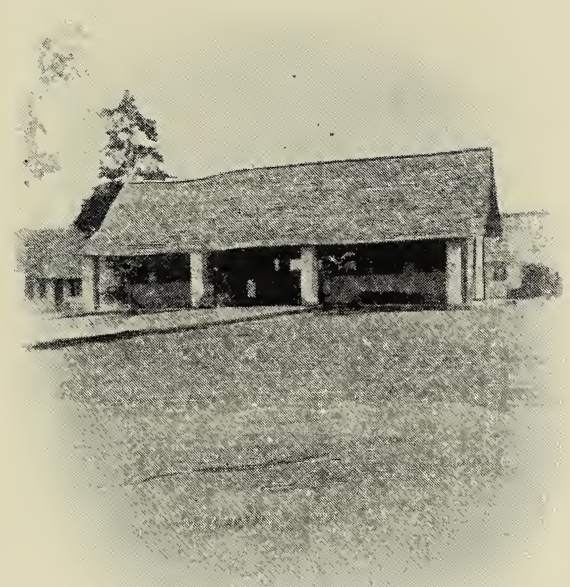

BANGALA.

presents. He was evidently in a great hurry to be off to Bumba, perhaps for the same reason as the chef de zone; perhaps because it was better supplied with eatables and drinkables. I had intended to speak to him with regard to the threatening attitude of my soldiers, and to suggest certain changes in the garrison, but he and his body-guard of 320 went off so expeditiously that I had no. opportunity of putting in a word. I am convinced that if he had been going the other way he would have found it necessary to remain at least a week; now, however, he was leaving danger behind, and consequently travelled much faster. He told me that 
he would return in fifteen days; but so many promises had been made to me and left unfulfilled since I took over the Monjoa command that I had now determined to follow in the future the course which my judgment told me would be for the best. I had at that time a supply of provisions just sufficient for eighteen days, and determined that if the commissaire or some other official of the State did not appear within that period I should dismantle the fort and make for the river with my little garrison. I recognised that I should risk much in traversing the country with such a band of sheep as my "soldiers" were likely to prove themselves, but, after all, it was better to die by the spears of the enemy than of starvation. My "force" now consisted of sixty-one persons, to wit, forty-six men armed with rifles (of whom twenty-two were recruits, and knew just about as much of shooting straight as they did of scientific astronomy), four women, nine boys, one porter, and one unarmed recruit.

My resolve was considerably strengthened by news received within twelve hours of the commissaire's departure. Soon after sundown the two soldiers whom I had detailed to act as escort to the chef de zone returned in a very flurried state of mind and with a circumstantial story to the effect that, on the way down the Malua, the canoes had been attacked by natives and the mundele (white man) killed. They themselves, of course, had only just managed to escape. The Budjas, it appeared, had cut down a large tree so that it would fall across the creek, and then secreted themselves on each side of the water. When the first canoe, with the mundele in it, reached the tree, it stopped for a few moments preparatory to "climbing over," as is quite frequently done on these little streams when obstructed by the trees which fall across during the rainy season. The stop gave the natives time to rush from their ambush and in a dense mass fall upon the white man. He fired two shots from his revolver and was then, the survivors reported, transfixed by dozens of Budja spears. Had this been so, he would have fallen a victim to his own temerity and the criminal carelessness of the commissaire in permitting him to travel in a hostile country without adequate escort. So far as I was concerned in the matter, I felt my conscience clear. I had offered the chef as many men as he wanted; moreover, as he was my superior officer, he had only to issue orders and they would have been 
carried out. The three canoes he had with him were old "dugouts," and after his baggage had been stowed away there only remained room for himself and his boy, the paddlers and the two soldiers. Although I had warned him that soldiers coming from N'Dobo with provisions for the fort had more than once reported native tracks in the mud and sand of the river-bank, I confess that I had not thought much of the possibility of an attack. I had passed over the same route as recently as June, and heretofore no attempt had been made to molest canoes. Even had Van Eyck provided himself with a stronger escort the result would probably have been the same, for, in the ordinary course of river travelling, he would have been in advance of his party.

For me the incident was full of significance, for it showed that the Budjas had at last found means to cut the communication between Monjoa and the main river - a somewhat serious matter now that the two alternative land routes were so dangerous owing to the Gombés having joined in the fight against the white man and his rubber régime. Of course my first care after receiving the bad news-for the killing of a mundele is accounted equal to a great victory by the natives-was to convey it to the commissaire de district, who, I calculated, would be encamped about three hours' march to the eastward of the post. I called for volunteers to carry a note to him, and, somewhat to my surprise, experienced no difficulty in persuading ten of the Abarambos (the men who only a few days before had conspired to kill me) to undertake the possibly perilous task.

On the following morning a detachment of 100 men, under the command of a black sergeant, came into the post with a reply from the commissaire. I was instructed to send to him the two soldiers who had deserted Van Eyck, advised to redouble my vigilance, and informed that the sergeant had been instructed to reinforce my command with twenty of his men. For the lastmentioned I was certainly not grateful. The men could be of no possible service, and I would rather that the commissaire had diminished than increased the number of mouths to be filled. $\mathrm{He}$ might, I thought, have considered that the post was absolutely dependent upon N'Dobo for supplies, and could hold out only just as long as food remained. 
I was favoured on the 1st of September with a visit from our new friend Yamikele, who, accompanied by a slave, brought as presents for me a small bundle of cassava leaves, with which, he was good enough to explain, I might make pundo, and a native cur (in his eyes no doubt a most choice specimen), which he hoped would serve to vary the normally monotonous diet of Monjoa. Having fortunately found an interpreter in one of my "boys" I was able to fitly acknowledge the gifts, of course supplementing my verbal compliments with presents from the "trade box." I urged Yamikele to visit me frequently, and promised that I would buy as much kwanga as he and his people could bring. I even returned, without regret, the toothsome cur, begging Yamikele to himself

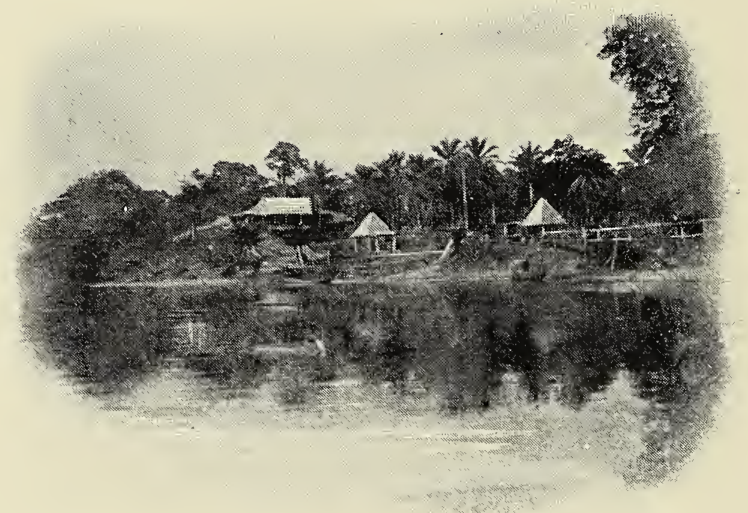

BARUMBU.

feast thereon in token of our friendship. The chief, though evidently ill at ease and obviously anxious to get away as soon as possible, made suitable response, and then loaded the slave with the presents I had bestowed. Once outside the gate, however, Yamikele was again the truculent Budja chief, and said to his companion in their common tongue that he would assuredly return, but with the special object of eating the white man-words overheard and understood by my boy belonging to the Gombé tribe. Yamikele, needless to say, I saw no more; nor was I very anxious, after becoming cognisant of his amiable desire, to renew our short acquaintance. 
On the 8th of September there appeared, not the commissaire, as he had promised, but a messenger from Bumba, bearing a letter from the supposed defunct chef de zone. With him also came other men, who had journeyed up the Malua by canoe, with supplies of rice and sweet potatoes, all of which were spoiled. It appeared from Van Eyck's letter that the two soldiers who acted as escort had simply heard the noise made by the Budjas when attacking the first canoe, and this had so upset them that they forthwith abandoned everything and fled into the bush. The chef, however, escaped by plunging into the stream and concealing himself near the bank among the thick overhanging foliage, whence he saw his baggage become the prey of the attacking savages.

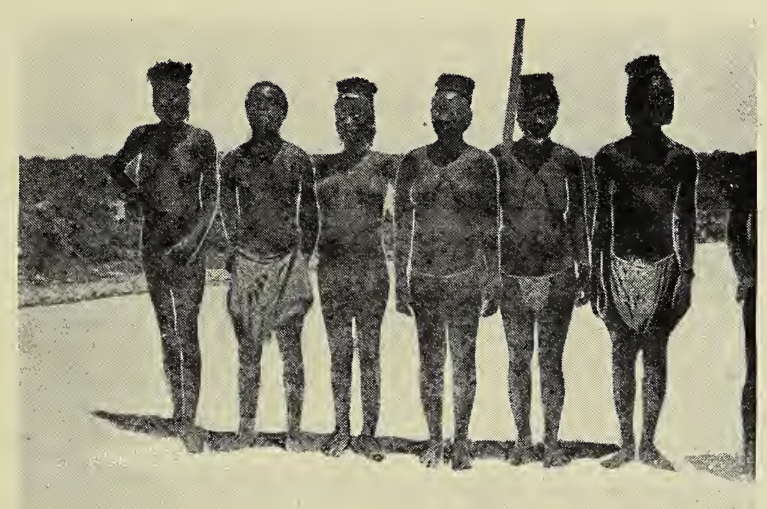

LOKANDU NATIVES.

He subsequently wandered about the jungle for seven days, sustaining life with such wild fruit as he could find, and finally made his way to Bumba, exhausted and almost naked. He now wrote that he had met with a slight "échec," meaning, I suppose, that he was wounded. "The incident," he added, "shows that the natives are not much inclined to submit." He might, it seemed to me, have arrived at the same conclusion when the first spear was stuck into him near Yambata; but some people apparently learn nothing from experience. The chef authorised me to abandon the Monjoa station, but at the same time remarked that this depended upon the decision of 
the commissaire de district, and accordingly I was advised to await the latter's instructions.

I did so, and with the usual result, for neither commissaire nor instructions arrived. Towards the close of the month, when there was left at the post but a cup of rice for each person and I had the best of reason to doubt the early arrival of fresh supplies, I determined to be the arbiter of my own fate and to make a dash for Bumba by the route followed by the expeditionary column a month before. Having buried the few articles of merchandise remaining, I mustered all my people and explained to them the position in which we were, and that it seemed to me far better to risk being killed by the Budjas than to starve to death like rats in a trap. The answer to this was a joyful yell, and the native equivalent to a vow " to conquer or to die." All were in a frenzy to start at once, and I was busy showing the men how they should act in the event of an attack, when the sentries announced that they heard shouting from the direction of the Malua. A few minutes later there appeared amongst us a white man and some soldiers who, it seems, had been sent from Bumba to relieve me, and with them came a letter from the commissaire de district informing me that it had been agreed between the company and the authorities of the State that the country of the Budjas should be forthwith evacuated by the former until the natives had been "pacified" by the soldiers of Bula Matari.

The next morning I embarked my Bangalas in the canoes which had brought our relief, and, with a score of soldiers who were to return to Bumba, started down the Malua. The Abarambos, much to their disappointment, were left behind. I promised that I would intercede on their behalf with the authorities, and did so, but I believe that they were kept at the post for some months longer.

On arrival at Bumba I reported to the lieutenant in command the state of affairs in the neighbourhood of Monjoa, and then took canoe for the company's post at N'Dobo. Here I found, but without any anticipation of contentment, my long-missing trunks. When I took over the command at Monjoa I was informed that they had gone into the interior to a place called Dundu Sana along with the baggage of the commandant. A promise was given that they should follow me to Monjoa, but this was 
the last I heard of the matter, and two letters which I sent to the authorities had the result usual in such cases-not a line in reply. I now found the trunks half full of water, in which condition they had evidently been for some time, for the greater part of the contents had rotted into a mass of dripping pulp. Judging from previous experience of baggage and goods which has been knocked about for any length of time in canoes, Congo steamers, or the jungle, I should have been very agreeably surprised had any of my possessions now been usable. This reflection, however, did not make me the more happy, for my outfit was a good one and cost much hard-earned money, and I already knew the Société Anversoise too well to expect a cent in the way of compensation.

While at N'Dobo, as a consequence of the sudden change from a rice to a meat diet, I contracted a not mild form of dysentery, and this compelled me to tarry for nearly a month awaiting an opportunity to get down to Mobeka. I was for a long time too feeble to march, and during the whole time mentioned no canoes were available for the journey.

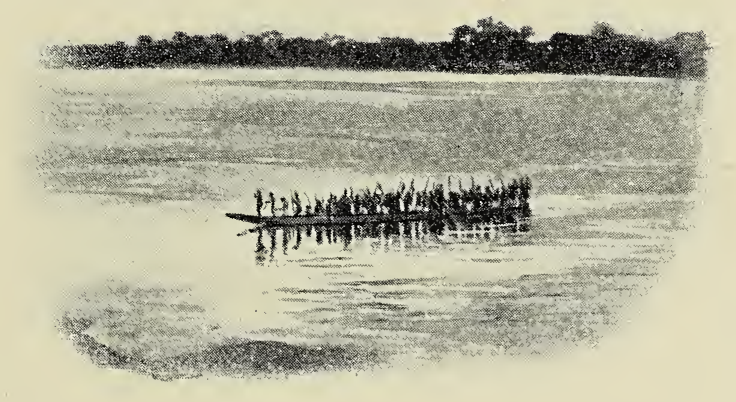




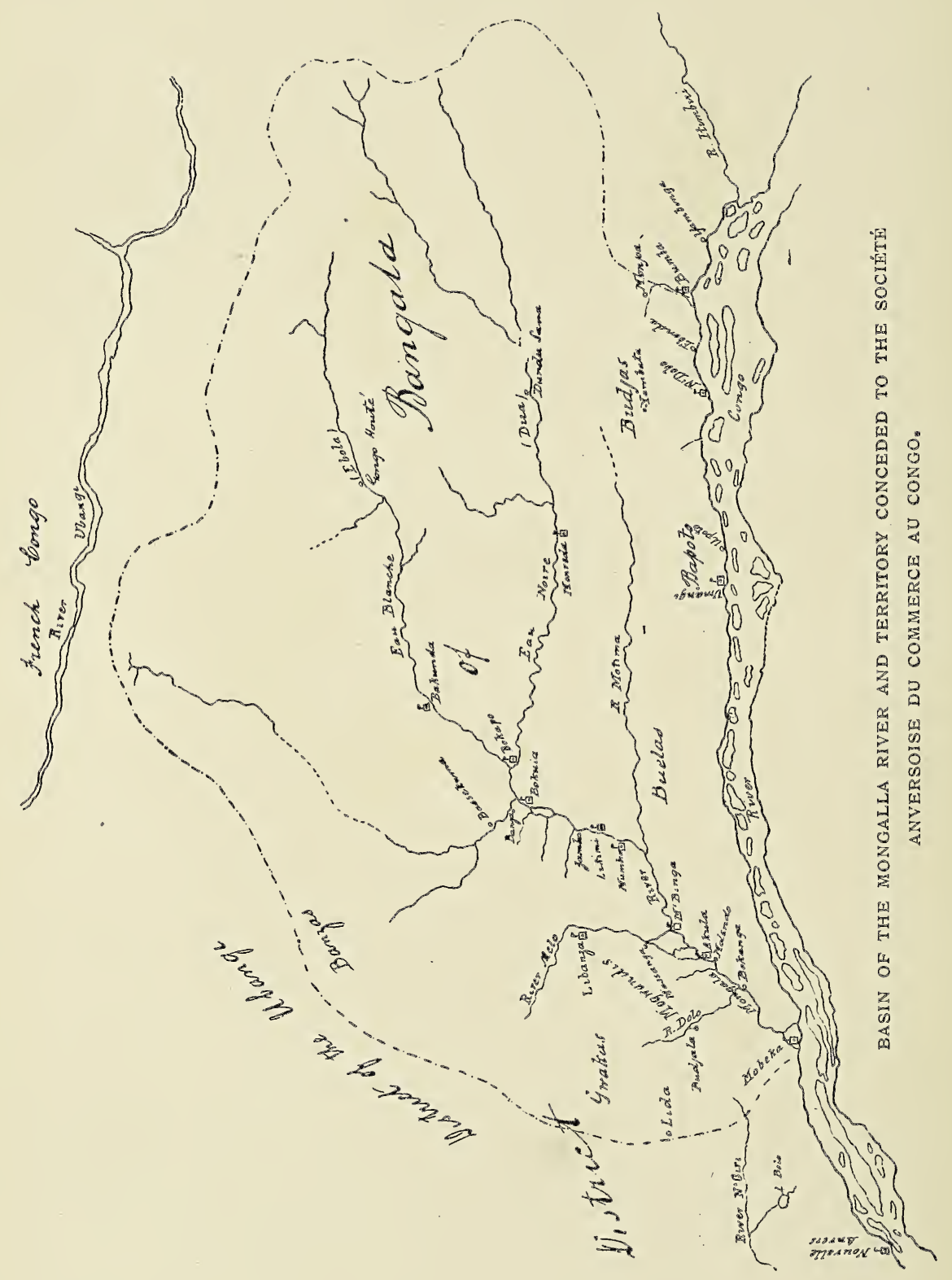




\section{CHAPTER XI.}

THE MONGALLA ATROCITIES : THE MASSACRE OF THE GWAKAS.

My Post at Akula-The :Capita-Chiefs-Attack on Molendo-The condition of the Natives-Massacre of the Gwakas-Bartering with Human Flesh-The State and "Atrocities"--Recruiting for the Force Publique-Djabbir's Traffic"Volunteering" in the Congo State-The African Negro as Soldier-Farewell to the Mongalla.

I REACHED Mobeka from N'Dobo in one of the steamers of the State. Thereupon I was requested to immediately proceed to a post called Akula, as the agent in charge there was ill and wished to return to Europe. Hoping that my recovery would be hastened by the comparative tranquillity which was reported to reign in this portion of the Mongalla concession, I accepted the appointment, and within three days reached Akula. I could not, however, shake off the disease, for at my new station, though quiet, there were no means of effecting a cure; here, indeed, as at other Congo posts, I found none of the comforts and few of the necessaries of life.

The region of the Mongalla was now in a state of transition. Strict orders had been received from Boma that the hitherto continuous massacre of the natives must cease. It was ordained that each post should contain but twenty-five rifles, which were on no account to be used for any purpose other than defence against attack. White men were forbidden to march through the country with armed bands, and if it were necessary to traverse or send merchandise through a region which was hostile, an application for an escort was ordered to be made to the nearest State post. Such escort, however, was very seldom granted, on account of the insufficient number of soldiers available.

In this portion of the Mongalla concession I found quite a different system of rubber-gathering to that in vogue in the Budja country. Each post had established in the principal villages 
capita-chiefs-men selected generally on account of their superior intelligence and audacity. These capitas assumed great state among the natives, and had under their command scores of assistants recruited from the scum of the native population. They were supposed to see that the natives collected the rubber, and they ensured this generally by means of blows, and occasionally by a bullet from their "gas-pipes." The manager of the "factory" entrusted to the capita-chief a quantity of merchandise, sufficient to pay the natives for their rubber at a rate not exceeding threepence per pound; but the capitas usually appropriated the goods to their own use, and took the rubber without any payment whatever. Some of them had, as the result of these peculations, become the possessors of dozens of wives and many slaves.

They literally "ate up" the country by forcing the natives to bring to them goats and fowls and other provisions, for which they paid out the small quantities of merchandise belonging to the white man originally intended as recompense to the rubber-gatherers. Some of the capitas had hundreds of armed followers, who went about in bands devastating the villages, ravishing the women, and shooting down the men on the slightest provocation. They held the entire country in a state of terror. Several of the capitas who had been soldiers had fortified posts, where they assembled their bands and put them through a regular course of drill. Upon arrival at such places, I have often seen a body of these men "fall in " and "present arms" with greater precision than any of the "regulars." They were usually, engaged as labourers at the munificent wage of about three shillings a month, paid in mitakos; but the greater number of them, who were recruited by the chief capitas, were attached to the service by the opportunity for pillage which it afforded.

The people of the Mongalla country, chiefly Mogwandis and a rather mixed lot of Bangalas, Banzas, Buelas, and others, have had a severe time of it under the company's rule. The villages in the neighbourhood of the posts were compelled to furnish fish, building material, and also paddlers to man the canoes which are largely used for transport on the river. The post of Akula is built on soil brought basket by basket from the neighbouring swamp; consequently the ground upon which it stands has become an island, raised from the swamp by the unremitting and unpaid labour of 


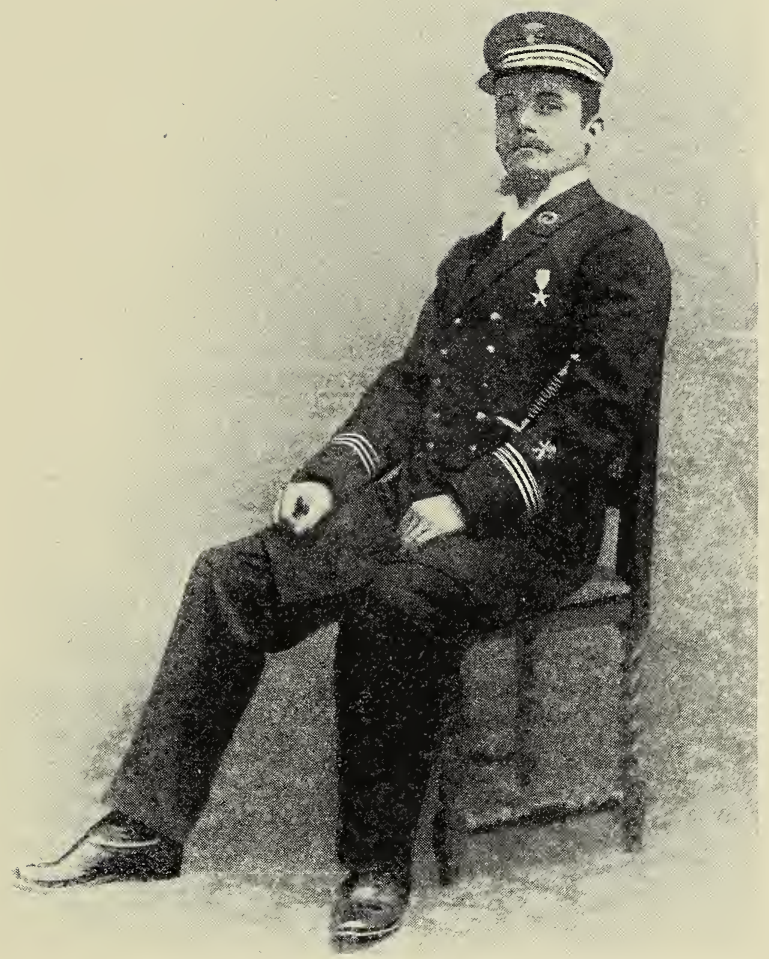

LIEUT. BRAECKMAN, IN COMMAND OF THE MONGALLA EXPEDITION. 
hundreds of native women. I am sure that Pharaoh was no harder taskmaster to the Israelites than the Société Anversoise has been to these people. Even after my arrival and the prohibition of the Governor-General, the chief de zone, who had his residence at Akula, sent soldiers to the village of a chief called Molendo and, by attacking it at night, captured a large number of women and children. The alleged reason of that outrage was Molendo's neglect to send his women to carry earth to raise the level of the land at the station-a work which had been going on for years, and of which the natives were heartily tired, for during the time they were so occupied their women produced nothing, and there was much hunger in the villages. During this attack, the soldiers fired upon and killed several of the natives.

I made various journeys into the interior during the months I remained at Akula. Everywhere I found a shocking state of affairs, and the natives dying of famine by the score. Continually harrassed and slaughtered at the behest of the white men, they had ceased to plant food-products, for they derived no personal benefit from their labours, the capitas and soldiers taking everything; consequently the people were now living like wild beasts in the forest, subsisting on roots, and ants and other insects. I have passed along paths where occasionally the putrefying corpse of a native might be seen, and this was the case even far away from the river. The people had evidently penetrated the thick jungle in the hope of reaching another line of villages, but, being too feeble for a long journey, had fallen by the way.

About the time of my arrival at Akula, a "police post" had been established at Bokula, some two days' steam up the river, and here a lieutenant, Braeckman by name, and a non-commissioned officer were stationed with about fifty men. In accordance with a prearranged plan, the chef de zone sent into the interior some twenty-five of the company's men under authority of a "permis d'escorte," a document issued by the commissaire de district to those chefs de zone who wished to convey merchandise from one post to another. Such a document, of course, very effectively nullified the orders of the Governor-General against the gathering of armed bands in the native villages. All that was really necessary was to fill a case with cheap merchandise, secure a hundred or so men to escort it, and, after an opportunely-imagined 
attack from the natives, shoot down as many of the latter as seemed desirable in order to induce them to augment their rubber supply. In the case mentioned, the horde of company's men, under one of the black corporals of the State army, made off joyfully into the bush, for here were no Budjas to mass their warriors in an ambush, but only cowardly Mogwandis. A few days later they were joined from Bokula by the lieutenant and his men, the chef de zone, and another white man from the post at Libanza.

The united force than attacked a small tribe known as the Gwakas, and, according to the statement of the lieutenant, killed about three hundred of these people. The only charges against the latter were that they had deserted their villages and taken to the jungle and killed one of the capita's men in a scuffle. No attempt was made to arrest the actual murderers, who were no doubt amply justified in defending themselves against the violence offered them, but all were shot down indiscriminately. When the lieutenant returned to Akula he brought with him many prisoners of warmostly women-poor gaunt creatures, ready to drop from hunger and exhaustion. At least one, to my certain knowledge, died of starvation while imprisoned at the post, and was buried by my men in the swamp. The survivors were taken to Bokula, where they, no doubt, are still labouring for the benefit of Bula Matari.

I have yet to learn that any but the most perfunctory inquiry was ever made concerning this altogether discreditable affair. Yet there was no dearth of witnesses available to describe one or more of its most prominent incidents-for instance, Lieutenant Braeckman himself; M. Ignace Loumaye, chef de zone de la Melo; M. Charles Caudron, chief of the factory at Libanza; M. Weyns, chef de poste at Budjala; Captain Christianus, of the steamer "Lothaire," on which the prisoners were conveyed to Bokula; Silvanus Jones, of Lagos, the black carpenter at Akula, and the two native non-commissioned officers, Mabruki and Benge, both of the Force Publique, who had been detached for service with the company.

After "pacifying" the Gwakas in the manner described, Lieutenant Braeckman and his gallant men proceeded to the north-west frontier of the Mongalla company's concession. Here, at a post called Lida, had been stationed a Likwangula capita named Zonga, a person apparently held in small esteem by the 
employés of the State who were posted on the N'giri River. Having claimed that the capita station was outside the concession, and, therefore, State property, these white men, with a number of troops, attacked and destroyed Lida- a proceeding followed, first, by a very acrimonious controversy between the agents of the State and company, and then by inquiries at Lida and Budjala, conducted by the Substitut du Procureur de l'Etat of the district.

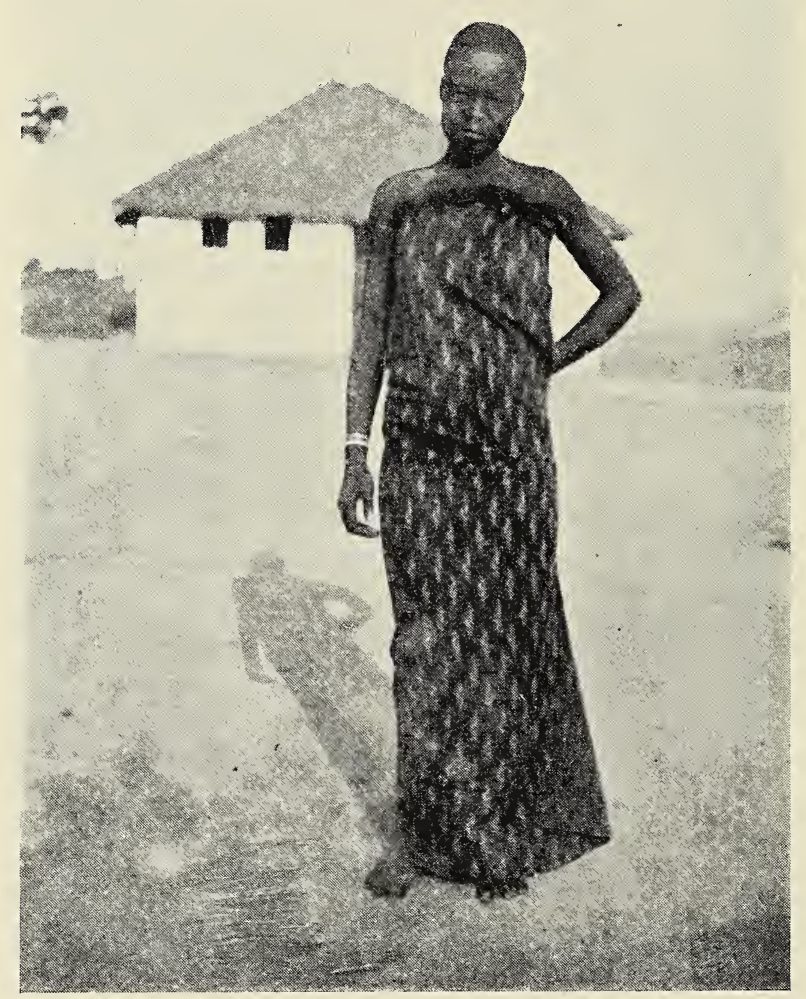

MANYEMA WOMAN.

I am afraid that, even though exhorted thereto by the most devoted apologists, the State would hesitate to submit to the judgment of civilization the papers dealing with this affair. In the course of the dispute and, I believe, the investigation also, the State and company's agents mutually accused each other of having purchased rubber with human flesh, of which, it was said, a quantity had been found in one of the capita posts. As it was 


\section{The Curse of Central Zftrica.}

notorious that the N'Giri region had been almost depopulated by the agents of the State, it was quite as likely that the "meat" came from State territory as from that of the company. Whether company or State, it is very certain that one or the other, and perhaps both, had been guilty of this awful barter. Whichever it was, the State lost no time in fixing the blame upon the company's agents, and at the time of my departure one black capita had been

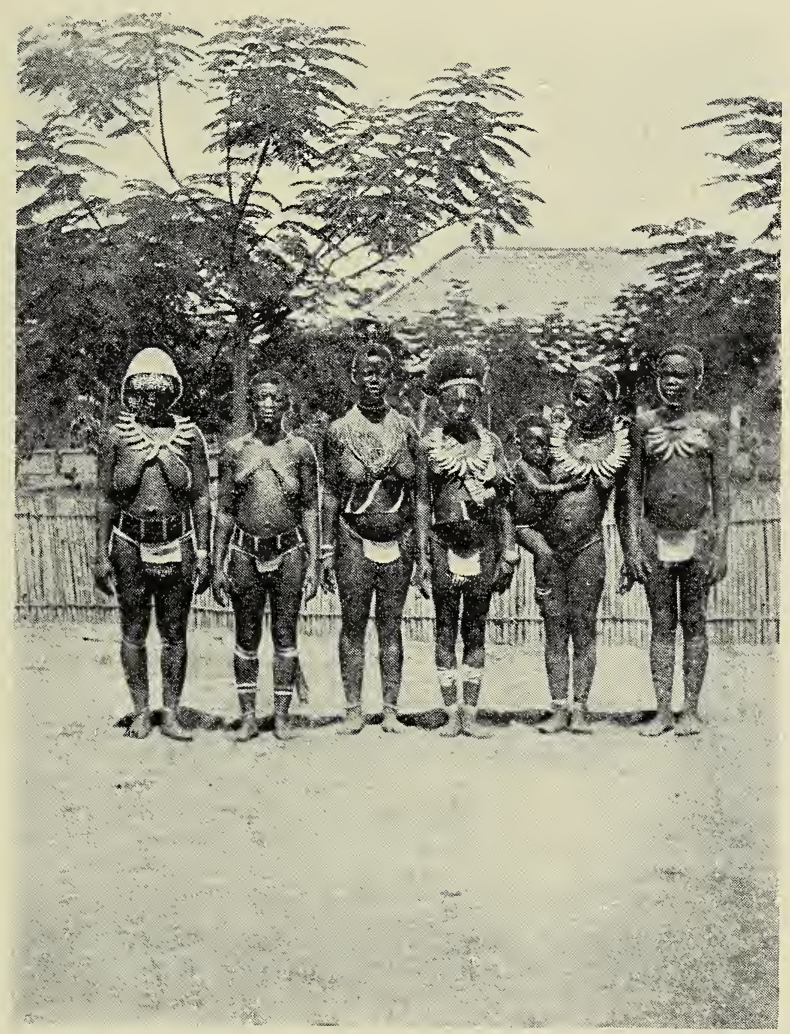

CHIEF AND HIS WIVES.

arrested; but his white employers, of course, were left unmolested. The "atrocity" business had been merely taken out of the hands of the company's agents for the nonce and placed in those of the State. The latter might massacre as many natives as it wished, but such acts on the part of its agents were not to be considered as "atrocities" - merely necessary measures for the efficient administration of the country. 
The natives, however, will not forget these deeds of the white man, and, when they have learned to subordinate their tribal animosities to the need of common resistance, the storm of bloodshed which the Belgians have been preparing for themselves or their successors-for all nations to the blacks are but mundeles-will burst upon innocent and guilty alike.

A few additional words concerning the Force Publique, or army of the Congo, may here be opportunely introduced. The first recruits to this remarkable agency for spreading "the light of civilization" in Central Africa were taken from the more progressive peoples inhabiting the coast regions, principally British territory. These were Zanzibaris, Abyssinians, Haussas, Sierra Leones, Accras and Elminas. That the British colonial authorities should have permitted the recruiting in British territory of men intended for the oppression of the native tribes of the Congo was certainly not creditable to the Home Government, which has during recent years so much prided itself on being the "protector" of the black peoples of the earth. Of the many thousand Africans first enlisted for service in the Congo, but few have returned to their native lands, the majority having fallen in the incessant fighting which followed the inception of the "rubber régime."

The Congo authorities soon came to the conclusion that one shilling per diem was extravagant payment for soldiers, and as far back as 1886 an effort was made to secure recruits from among the cannibal tribes of the interior. Some Bangalas were sent down to Boma, where they were drilled, and these formed the nucleus of the present army, their pay being about twopence per day. As the State established its authority in other parts of the territory committed to its care, a regular system of recruiting was instituted, each district being called upon to furnish a certain number of conscripts. To explain the modus operandi then established and since in vogue requires few words. The commissaires de district have orders to see that their quotas are promptly forthcoming, and each naturally enough delegates the duty of recruiting to his chefs de zone, who, in their turn, call upon the more subordinate chefs de poste to levy upon the local chiefs for the men required. The native chieftain usually makes his selection from the worthless and recalcitrant slaves of the village, 
who, when they reach the station, are promptly placed in the chain, or "collier national" as the Belgians call it, so that they cannot escape.

While journeying up the Congo some years ago I was surprised to see, coming on board at Coquilhatville, a gang of Wangatas attached to a long chain. On asking why they were chained, I was told that some of them were assassins and thieves, while others were prisoners of war taken in a recent rubber palaver. It was usual, when the steamer stopped at nightfall, for the Bangala crew and prisoners to camp on shore. Consequently, when on several occasions the crew reported that one or more of their charges had died of starvation, cannibalism was shrewdly suspected. However, neither the captain of the steamer nor the other white officials on board troubled about the matter; all accepted without question the statements of the crew. A few days after our arrival at Stanley Falls I observed the survivors on the parade ground attired in the red fezzes and blue cotton uniform of the State, each awkwardly handling an Albini rifle. I was informed that they were now soldiers, and were to go up to Kassongo to be drilled. Later on I frequently saw detachments of troops forming part of the army gathered to fight the mutineer Bakussus-once under Baron Dhanis's command-who had never fired a shot. Indeed they received their first cartridges from myself on the very day of their departure for the front.

In some districts the recruits are purchased. From Djabbir, one of the great chiefs of the Uelle district, the State is said to have obtained many hundreds, the price paid being generally one muzzle-loading musket for ten men. It is alleged that Djabbir has many thousands of muskets and a not inconsiderable number of breech-loaders acquired in this way. The traffic is a very simple matter for the dusky potentate, of whom the Belgians seem to stand in much awe; he only has to send his followers to raid the neigbouring tribes, and capture as many recruits as the representative of the State may require. With ivory he purchases ammunition from the State posts; for when the sale of firearms to the natives was forbidden, the Government, of course, exempted itself from the operation of the law.

The Governor-General is the titular head of the army; but for administrative purposes there is also, at Boma, a Commandant 


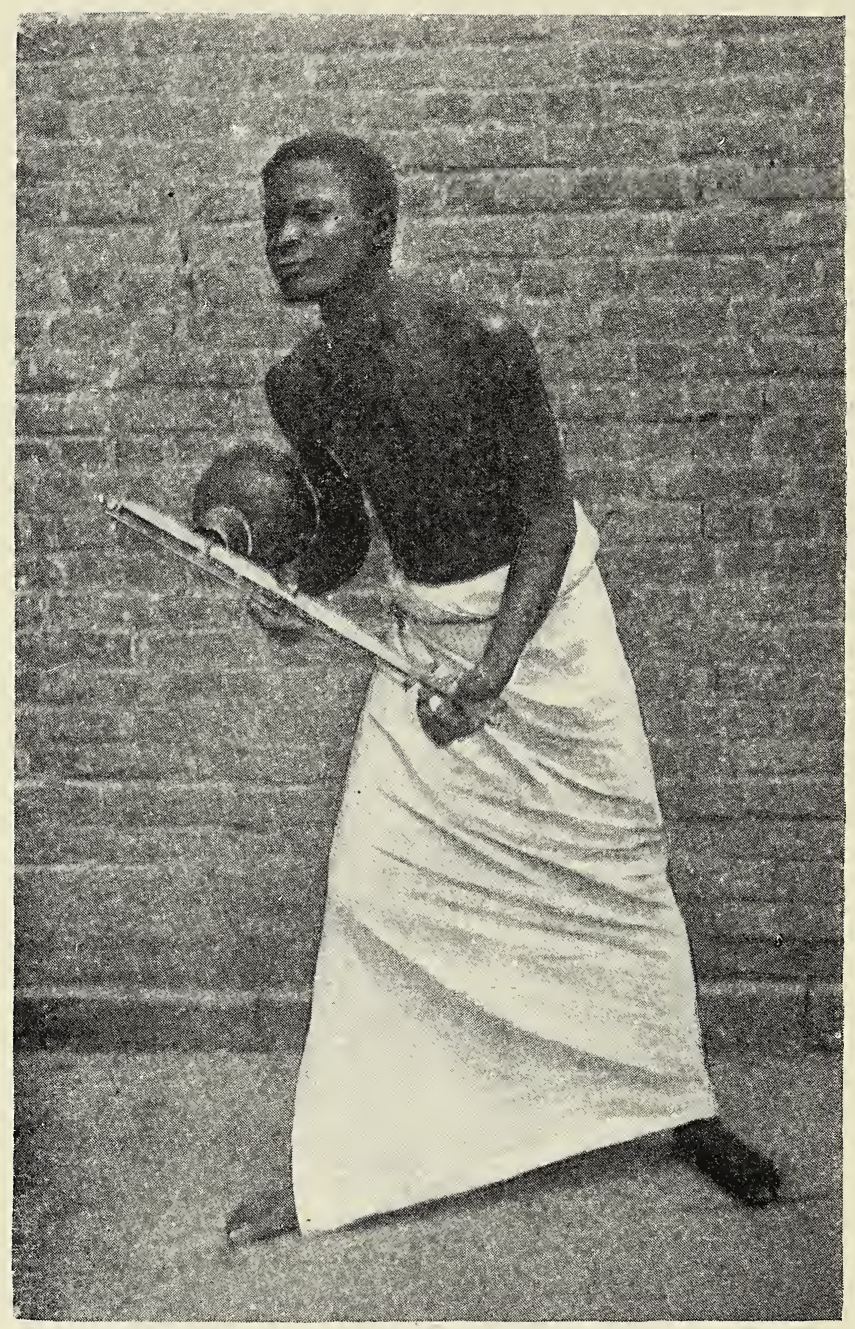

"TOBY," SIERRA LEONE PRISONER. 


\section{The Curse of Central $\mathfrak{A} f$ rica.}

en Chef. The divisional commands, or regiments, are called "companies," whose strength varies according to circumstances, and at the head of each is placed a commandant. His rank and authority, of course, are inferior to the commissaires de district, who command the local garrisons. The Force Publique has always been conspicuous for its dearth of European officers, and, though Belgians still occupy the highest positions and are a considerable majority, many commissions of late have been bestowed upon Italians, Greeks and Roumanians. According to official returns, the army in 1899 numbered 14,000, of whom 8,000 were militia, 4,000 " native volunteers," and 2,000 volunteers from the coast. These figures, however, are somewhat misleading, for in the Congo the term "volunteer" has quite a different meaning to the ordinary. During nearly three years' experience in a State post, I saw but a solitary volunteer present himself for enrolment, and, as transpired later, he was only driven to this course in consequence of having become "mixed up" with a dusky lady whose husband was looking for him with a spear. From the same post, however, were sent many "volunteers" chained together so that they could not escape.

In 1898, according to the Budget issued by the Finance Department, the sum of $6,870,631$ francs was devoted to the Force Publique. Of this, a very considerable percentage must have gone to the Belgian officers who swagger about the camps and stations radiant in gold lace. I cannot reconcile myself to the belief that a fair proportion went to the men, for the latter were nearly always as ragged as the typical plantation darkey of Alabama.

The record of the Force Publique, both as a fighting machine and as an instrument for exploiting the natives, goes far to justify the oft-repeated assertion that the African, as a general rule, is not suitable material for the making of a good soldier. That he is frequently unreliable, and likely, on occasion, to prove as dangerous to his employers as the enemy has been proved in the Congo by the revolts at Luluabourg and Kinchassa, and of the troops of Baron Dhanis's expedition to the Nile. From other quarters might be quoted, in support of the same argument, the scandalous conduct of some of the negro regiments of the United States, and the not rare mutinies of black soldiers in the British servicethose, for instance, of the West Indian troops, of the Soudanese 
in Uganda, and of the West African regiment at Kumasi. It is experience, and not prejudice, which prompts my opinion that no government calling itself civilized should employ African negroes to bear arms for it. These people have little or no idea of the virtues of patriotism and devotion to duty, and often enough lack the intelligence to realize the absolute need of discipline. It cannot be expected that within a few years or generations civilized man can be evolved from the cannibal savage.

My stay in the Mongalla came to a close in the month of April, 1901 , when the state of my health urgently demanded a return to Europe. A steady diet of baked plantains and kwanga was but a poor substitute for the milk and eggs needed to cure stomach diseases, and the parsimonious directors at Antwerp were evidently determined that we should have nothing better. Therefore, after having vainly sought the medical aid which the company had contracted to provide, I took the first steamer going to Leopoldville, and soon after shook from my feet the dust of Africa's fever strand.

That the company for which I had suffered much is surely tottering to its fall is to me a matter of small regret. By its longcontinued barbarities to the natives, its infamous treatment of its white agents, and its unequalled rapacity, it has forfeited the sympathy of even its most faithful employés. It is freely stated among the agents of the company that the magnificent "crops" of rubber gathered in the Mongalla region, which have for a long time equalled sixty to eighty tons monthly, valued in Europe at from $£ 20,000$ to $£ 25,000$, have awakened the avarice and jealousy of that larger monopoly, the Congo Free State, and that the severe "repression" of atrocities is merely an expedient to compel the company to return its concession to the beneficent care of Bula Matari. Be that as it may, it is certain that the company's concession has already lost much of its value. 


\section{CHAPTER XII.}

\section{BELGIUM AND THE CONGO STATE.}

Baron Dhanis's Disclaimer-King Leopold as an African Pioneer-The International African Association-Sir H. M. Stanley's Exploit-King, France and GermanyThe Berlin Conference-Belgium's Indifference-The Creation of the StateThe King's Testament-Belgo-Congolese Finance-The Relations of the Two Governments-Proceedings in the Belgian Parliament-The Compromise of IgoI -Its real Significance.

There was published in the Pall Mall Gazette of 31st October, 1901, an interesting communication from Baron Dhanis, in reply to certain statements concerning the condition and economic prospects of the Congo State which had appeared in the same journal about a fortnight earlier. Not the least valuable-but, from many points of view, certainly the most suggestive-portion of this letter was that in which Baron Dhanis took exception to references to the foundation of the State as a fruit of diplomacy, and "due largely" to the anxiety of the Great Powers to safeguard Central Africa from becoming a bone of contention amongst themselves. Objecting to this reading of history, Baron Dhanis maintained that to King Leopold II. and his subjects belongs the whole credit for the establishment of the State; that the international arrangements of 1884-5 have no greater importance than that of "officially" recognising a nation which already had a previous existence; and that practically the only duty of the representatives of the Powers assembled at Berlin was to act the part of chorus to chant praises of the King-his lofty views, great energy, indefatigable tenacity and other effulgent virtues. It is, of course, impossible to say how much, or little, of this argument was "inspired"; this, however, seems all but certain-that the ex-Vice Governor-General did not write without the knowledge, and perhaps authority, of the highest dignitaries of the State. This 
being so, Baron Dhanis's letter may be regarded as a semi-official repudiation of the views entertained in many countries that King Leopold is responsible to the Great Powers for the proper government of the Congo, and that, if it can be shown that treaty obligations have been defied, it is not only within the province, but the positive duty, of the nations concerned to demand inquiry and exact reforms.

It may be of interest, in the first instance, to outline the history and nature of the bond between Belgium and the MidAfrican State. Leopold II. we all know as a monarch of many

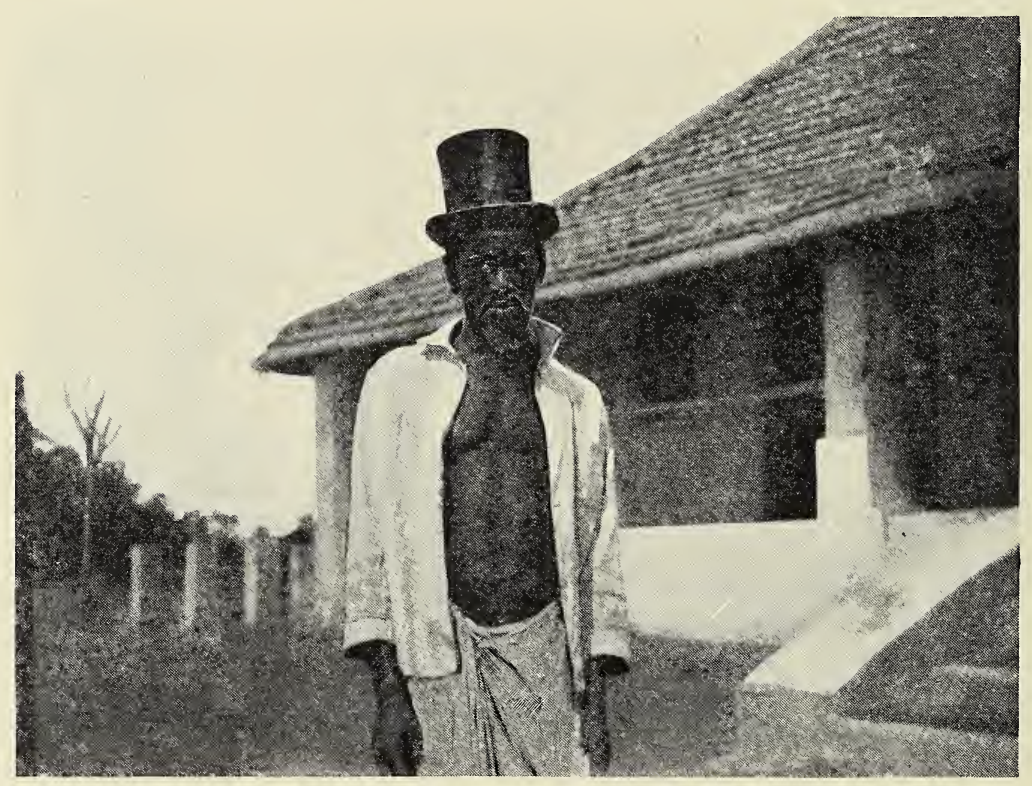

NATIVE CHIEF.

solid virtues, more usually encountered on 'Change than among the occupants of thrones. Even as heir-apparent he entertained visions of a Belgium beyond the seas, and, indeed, made memorable his majority in 1855 by a speech in the Senate, in the course of which he said: "A young nation such as ours should be bold, always progressive, and self-confident. To dare is to succeed." His imagination was fired by the sensational discoveries of the great African explorers, Speke, Cameron, Burton, Grant, Livingstone, Stanley, Nachtigall, Rohlfs, Junker, Schweinfurth, and 
others; and it must be admitted, whatever may have been his ulterior motives, that Leopold II. made the whole world his debtor by his consistent support and encouragement of such men of science and daring. To his initiative was due the Geographical Conference held at the Royal Palace in Brussels in September, 1876, and which was the origin of the International African Association. Before adjourning, the Conference elected an International Commission under the presidency of the King, and with Baron Greindl as general secretary, the other members being Dr. Nachtigall, M. de Quatrefages and Sir Bartle Frere, the place of

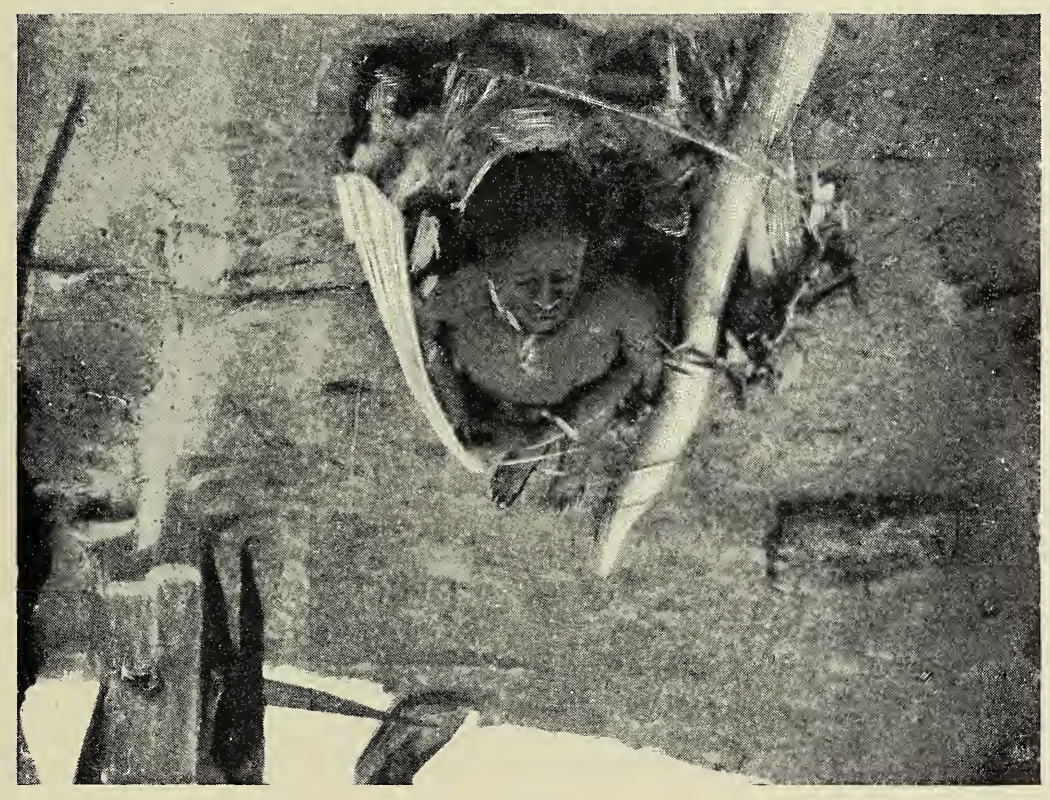

BODY OF A MURDERED WOMAN.

the last mentioned being taken soon afterwards by Mr. Sandford, ex-United States Minister at Brussels. The first meeting of this Commission was held at Brussels in June, 1877, and decided that the caravan route from opposite Zanzibar to Lake Tanganyka should serve as the base of the initial enterprise; that the Belgian Committee should organise the first expedition; and that the flag of the Association should be blue, with a golden star in the centre. From 1879 to 1884 numerous expeditions were dispatched under the auspices of the Association; those of the Belgian Committee 
met with scant success, but that organised in France under De Brazza resulted in the foundation of the Gaboon colony and the French Congo; while from that of Boehm and Reichardt was evolved German East Africa.

It is, however, to newspaper enterprise and the indomitable heroism of the then Mr. H. M. Stanley that the world owes that knowledge of the heart of Africa which was destined within a few years to make little Belgium the arbiter of the vast watershed of the mighty Congo. On the 9th of April, 1877, there arrived at Boma the remnants of the expedition which almost three years earlier had left Zanzibar, and nine months before had marched out of Nyangwe with the idea, apparently at that time ludicrous, of traversing the continent. Stanley, however, proved that not only was this possible, but that there existed, to aid the undertaking and in future days further the development of such resources as the country possessed, a mighty stream, stretching from Lake Moero, eight degrees south of the equator, to two degrees above that line, and thence reaching the Atlantic near longitude 12, south latitude 6. Compared with this giant flood, all the other rivers which flow towards the two sides of equatorial Africa appear little more than rivulets. It is, therefore, small wonder that Stanley's account of his historic journey created a lively sensation among geographers and far-seeing commercial men, and that the latter soon recognised that the long-sought route by which central Africa might be opened to European exploitation had at last been found. Inspired by the King, the Belgian Committee of the African Association promptly changed its original programme and decided to abandon Zanzibar and Bagamoya for what promised to be the more profitable bases of Banana and Boma. So rapidly, indeed, was the new scheme of operations drawn up that, when Stanley arrived at Marseilles in January, 1878, he found there awaiting him two representatives of King Leopold with a flattering and tempting request that he would co-operate in the enterprise.

With time, King Leopold's scheme became more grandiose, and Stanley soon learned that it would be his mission to make inquiry concerning practicable means of reaching the Upper Congo, establish base stations among the riverside tribes, and obtain from their chiefs rights of occupation, which might eventually transform the yet almost unknown basin of the Congo 
into a dependency of Europe-in other words, he was to conquer "Darkest Africa" and plant throughout it the blue flag with the golden star. Questions of organisation having been discussed, first at Paris and then in Brussels, Stanley accepted the King's invitation, and a society, having a capital of 1,000,000 francs and entitled "La Comité d'études du haut Congo," was established. King Leopold became honorary president, the three vice-presidents of the Belgian Committee of the African International Association were elected honorary members, and Colonel Strauch, who had just succeeded Baron Greindl as general secretary of the same association, was appointed president of the administrative council. Thenceforward the enterprise was pursued with great activity, and, for some time at least, with remarkable secrecy. In the February of 1879 Stanley left Europe for Zanzibar for the purpose of recruiting porters, and on the 21st of August six steamers, having on board the first expedition, left Banana en route for the Upper Congo. Within the next five years agents of the Belgian society had moved among a hundred heretofore almost unknown peoples, obtained from the native chiefs five hundred acknowledgments of suzerainty, founded forty stations, launched on the upper river, beyond the cataracts, five steamers, and virtually occupied midAfrica from the Atlantic to Stanley Falls, Bangala to Luluabourg. It was a great performance, and one naturally calculated to excite interest, and even some disquietude, in Europe.

This was pre-eminently the case as regards France and Portugal, which claimed rights, the one to the north, the second south, of the estuary of the Congo. It was, however, England, strange to say, which nearly wrecked the fortunes of the nascent State, for she it was who, in February, 1884, in exchange for certain commercial privileges, recognised the sovereignty of Portugal on the two banks of the Lower Congo as far as Noki, thus depriving King Leopold's enterprise-which had now assumed the title "International Association of the Congo"-of all communication with the ocean by means of the Congo estuary. Thereupon the Association turned to France, and in April of the same year obtained from the Government of the Republic an engagement to respect its stations and territory, and to raise no obstacle to the exercise of its rights. For this the Association undertook not to cede to anyone its possessions, and to give to France a right of 
preference should unforeseen circumstances induce it at any time to realize its assets. In a convention dated February 5, 1895, the French Government has admitted that this "droit de préférence" could not take precedence of that of Belgium. King Leopold, however, found a more potent ally in Prince Bismarck, who protested on behalf of Germany against the Anglo-Portuguese treaty, and at the same time invited France to join with him in securing by international agreement a solution of the mid-African question. This was in April; in June he went a step further by publicly declaring in the Reichstag that the Belgian exploitation

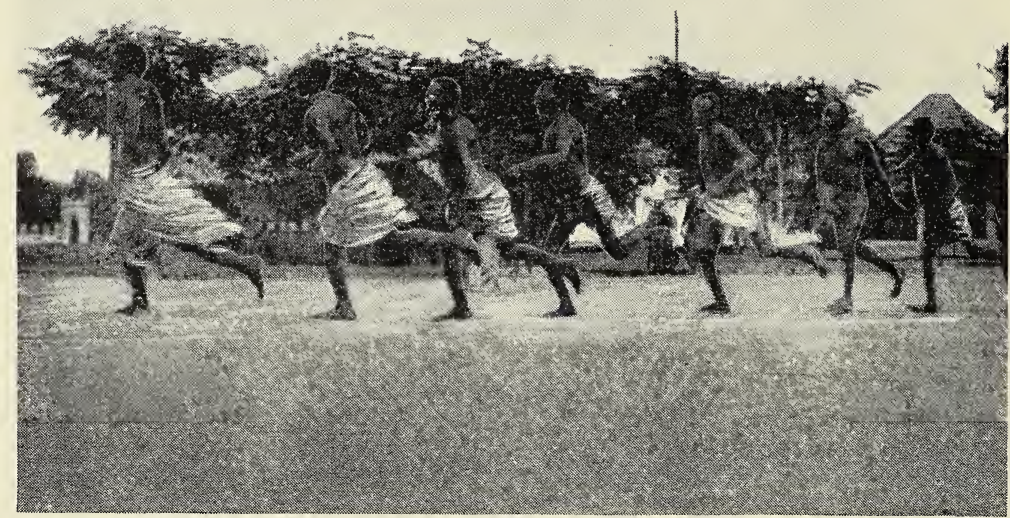

NATIVES RACING.

of the Congo had for end the foundation of an independent State, and that the Imperial Government favoured the project. Three days later the treaty with Portugal was officially "denounced" in the British House of Commons.

Prince Bismarck's overtures having been favourably received in Paris, and other Powers having promised to be represented at the proposed conference, the German Government officially recognised, on the 3rd of November, 1884, the International Association as a sovereign Power. At the same time it invited the 


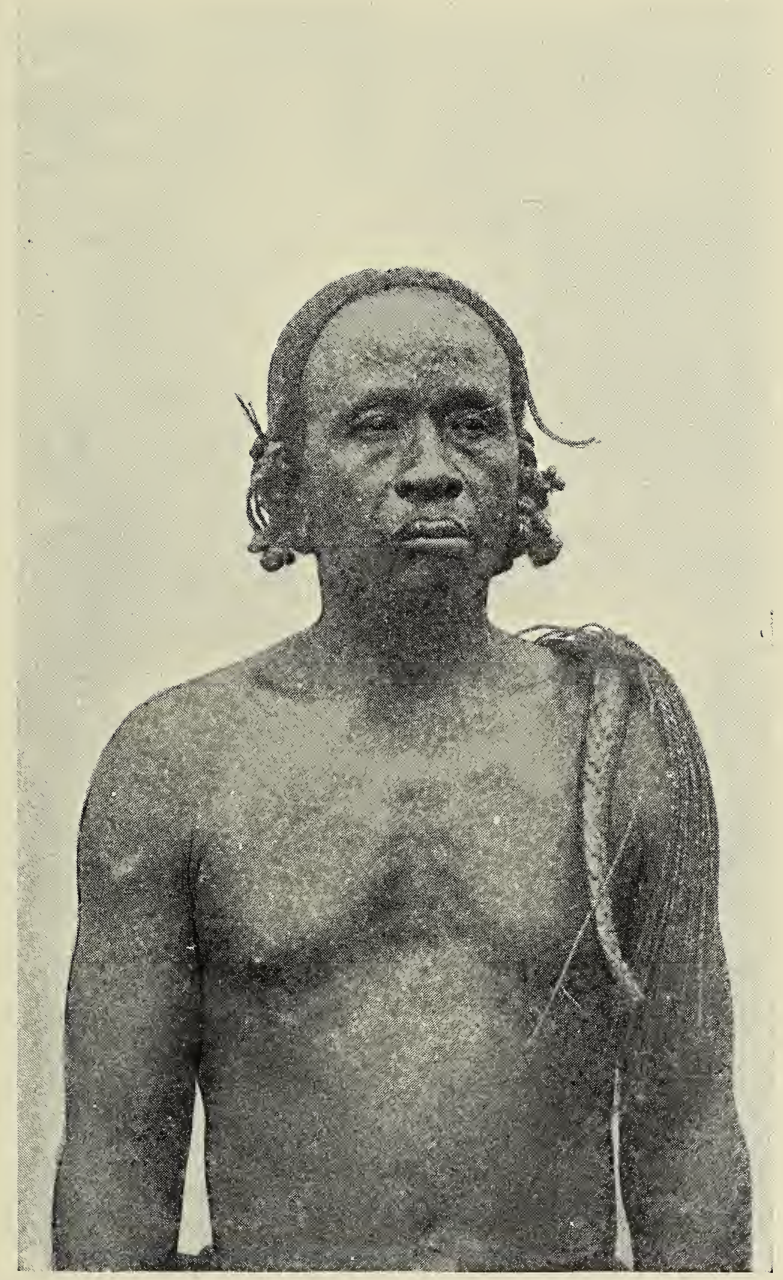

MOIMBA CHIEF (WHO FOUGHT AGAINST STANLEY). 
representatives of the Powers to meet at Berlin, with a view to an international agreement on the following principles:-

1. Free trade in the basin and mouths of the Congo.

2. The application to the Congo and the Niger of the principles of free navigation.

3. Definition of the formalities to be observed in order that new occupations on the coasts of Africa may be considered effective.

At the first sitting of the Conference on the 15th of November, fourteen Powers were represented, each by one or two plenipotentiaries and a technical councillor. For Great Britain, the late Sir Travers Twiss, and for the United States, Mr. H. M. Stanley acted in the latter capacity. The proceedings of the Conference extended over three months, and its decisions are contained in a document known under the name of the General Act of Berlin, and consituting a treaty in seven chapters and thirty-eight articles. To several of these decisions fuller reference will presently be made.

The Government of the United States of America had recognised, as early as April, 1884, the sovereignty of the African Association. Great Britain took a similar course on the 14 th of December, and the other nations gradually followed suit, the last two adherents being France and Portugal. Neither of these Powers showed itself unduly exacting, and with each a compromise was effected eminently favourable to the new State. The latter may be said to have been definitely founded on the 23rd of February, 1885, for at that day's sitting of the Conference Colonel Strauch announced that all the Powers represented at Berlin had fully recognised the International Association of the Congo, and that the latter would adhere to the General Act.

So far, Belgium had officially taken no part in the African work of the King, and this attitude was only modified on the morrow of the Berlin Conference by the King's request to the Legislative Chambers for authority to assume the sovereignty of the new State. The application, made in conformity with Article 62 of the Belgian Constitution, was contained in a letter to the Ministry of M. Beernaert, in which Leopold II. pointed out that, if the Chambers granted the desired authorisation, there would be between Belgium and the Congo State "only a personal bond." 
"I am convinced," he added, "that the union would be advantageous to Belgium, without imposing upon it any expense." The proposal was received with the same contemptuous indifference which had characterised earlier Belgian references to the King's African adventures. As M. A. J. Wauters remarks, in his book "L'Etat Indépendant du Congo," "the dominant feelings were astonishment, incredulity, distrust and prudence : all parties strove

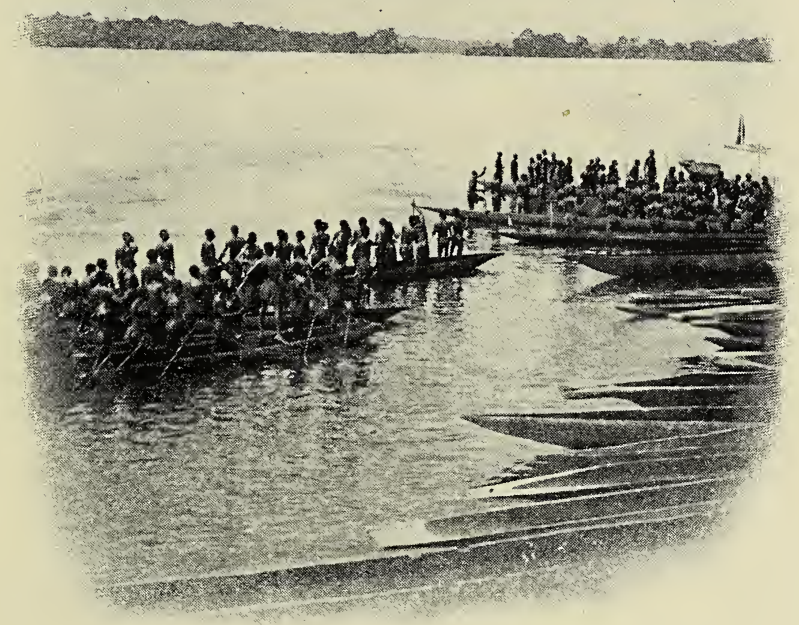

Native canoes on the aRUWimi, Basoko.

to relieve themselves of the responsibility of expressing an approval which they could not well refuse." It was only after certain reservations had been formulated by the Premier himself that the Legislature consented, in the following terms, to the Royal request: "H. M. Leopold II., King of the Belgians, is authorised to be head of the State founded in Africa by the International Association of 
the Congo. The union between the new Congo State and Belgium shall be exclusively personal." Three months later the King notified to the Powers which had been represented at the Berlin Conference the foundation of the State and his own accession to the throne. This document is the first in which mention is made of the "Independent State of the Congo," and of the title adopted by its head :-

The Government of your Majesty has been so good as to recognise the flag of the International Association of the Congo as that of a friendly State.

A.t the time of the signature of the General Act of the Conference of Berlin, the President and members of that high assembly, when receiving the adhesion of the Association to the work of the Conference, expressed their sympathies for its enterprise. Now that the position of the Association is determined from an international point of view, its territorial settlement established, and its mission the recipient of much valued encouragement, I am in a position to bring to the knowledge of your Majesty and your Government that the possessions of the International Association of the Congo will henceforth form the Independent State of the Congo. I have at the same time the honour to inform your Majesty and your Government that, authorised by the Belgian Legislative Chambers to become the head of the new State, I have taken, in accord with the Association, the title of Sovereign of the Independent State of the Congo. The union between Belgium and this State will be exclusively personal.

The new State, I am firmly convinced, will fulfil the expectations of the Powers which have in some way greeted in anticipation its entry into the family of nations.

I am firmly convinced that the new State will know how to show itself worthy of the benevolence of all the Powers; I shall endeavour to guide it in this way, and I venture to hope that your Majesty and Government will facilitate my task by giving a favourable reception to the present notification. 
At the same time, the foreign ministers of the Powers represented at the Berlin Conference were notified by M. van Eetvelde, the State Administrator of Foreign Affairs, that the Congo State "declared itself perpetually neutral, claimed the advantages guaranteed by the General Act, and at the same time assumed the duties which its neutrality allowed." It may also be here mentioned that Sir Francis de Winton (Mr. Stanley's successor) had already notified heads of the missionary societies and commercial houses of the foundation of the State, and that at Banana, on the 19th of July, he had proclaimed its constitution under King Leopold's sovereignty.

Belgium's second official appearance in the work of the Congo occurred in April, 1887, and had reference to a loan to the State of

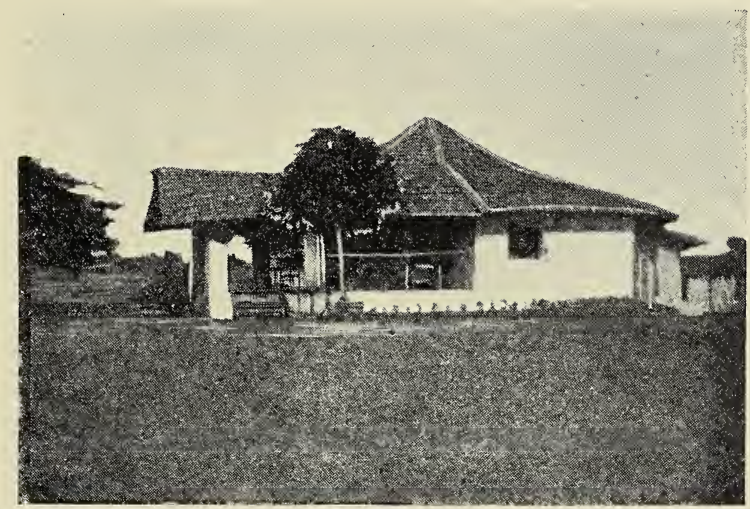

HOFFMAN'S HOUSE, BASOKO.

$150,000,000$ francs, authorised by the Belgian Government and Parliament. Two years later the Government afforded considerable assistance to a Belgian company organised for the purpose of constructing a railway across the region of the cataracts, and obtained the enactment of a measure authorising it to subscribe $10,000,000$ francs of capital. This sum was increased by $5,000,000$ francs in 1896, and at the same time Belgium gave its support to a subscription of $10,000,000$ francs in bonds. It was now evident that the large profits which were being earned by Belgians out of the Congo were increasing the confidence of the nation, and that, though the people generally distrusted the African adventure into which they had been led, the moneyed and commercial classes had 
ranged themselves on the side of the King. The latter, on the 2nd of August, 1889, two days after the incorporation at Brussels of the Congo Railway Company, signed a will in which he bequeathed to Belgium, after his decease, all his sovereign rights in the Congo, "such as have been recognised by the declarations, conventions and treaties concluded since 1884 between the foreign Powers on the one part and the International Association of the Congo and the Congo Free State on the other, together with all property and advantages attaching to this sovereignty." A year later circumstances induced the King and his Government to make this document public, and at the same time M. Beernaert read to the Chamber of Representatives a Royal message on the subject. In this, Leopold II. dwelt at considerable length upon his labours on behalf of Belgium and his African State, prophesied great things concerning the latter, and stated that if, before his death, Belgium thought well to contract a closer union with the Congo possessions, he would not hesitate to put them at its disposal. The impression created in Belgium by these documents was reflected in July of the following year by the signature of, and reception accorded to, the following Convention :-

1.-Belgium undertakes to advance on loan to the Congo Free State a sum of 25,000,000 francs immediately after legislative sanction, and 2,000,000 francs annually during ten years, dating from the first payment. During these ten years the sums thus lent shall not be liable to interest.

2.- Six months after the provided term of ten years the Belgian State may, if it thinks well, annex the Congo Free State, with all assets, rights and advantages attached to the sovereignty of this State, such as have been recognised and fixed, particularly by the General Act of Berlin of the 26th of February, 1885, and by the General Act of Brussels and declaration of the 2nd of July, 1880, but subject to the obligations of the said State towards third parties, the King-Sovereign expressly refusing all recompense on account of the sacrifices which he has made. A law will regulate the special administration under which the territories of the Congo shall then be placed. 
3.-Henceforth Belgium will receive from the Congo Free State such information as it shall judge desirable concerning the economic, commercial and financial condition of the State, and particularly the budgets of receipts and expenditure and the customs returns as to imports and exports. These particulars shall have no other purpose than to enlighten the Belgian Government, and the latter shall not interfere in any way with the administration of the Congo Free State, which shall continue unattached to Belgium except by the personal union of the two crowns.

4.--If, at the term aforesaid, Belgium should decide not to accept the annexation of the Congo State, the debt of 25,000,000 francs shall become due only after another term of ten years, but bearing interest at the rate of $3 \frac{1}{2}$ per cent. per annum, payable half-yearly; and even before that term the Congo Free State should set aside for partial repayments all sums accruing from cessions of territory or mines.

The Convention was without delay submitted to the Legislature and, opposition being for the moment dulled, was adopted without very serious criticism.

The next important movement in the direction of annexation was the revision, in July, 1894, of the Belgian Constitution by the addition to Article 1 of the following paragraph relative to the acquisition of colonies :-

The colonies, over-sea possessions, or protectorates which Belgium may acquire are governed by special laws. The European troops destined for their defence may be recruited only by voluntary engagements.

In spite of the financial assistance given to the Congo State by the Belgian King and Government, it soon became evident not only that the normal expenditure was exceeding the receipts, but that, for some years at least, there was little prospect of an equilibrium being established. The Congolese authorities themselves recognised the fact by seeking powers from the Belgian Government to contract new obligations, and this seemed in official circles in Brussels to afford an excellent opportunity for at once acquiring the entire administration of the Congo. The King 
declared himself ready to immediately cede his African possessions to Belgium, and the Ministry, on the 12th of January, 1895, submitted to the Chamber of Representatives a measure giving effect to this proposal. Instead of evoking enthusiasm, as had been anticipated, the Ministry's action aroused a storm of opposition, followed by an active propaganda, in which the whole Congolese régime was very roughly criticised. A day in June was appointed for what promised to be an impassioned debate in the Chamber; but on the 18th of May, in the Parliamentary Committee to which the projet de loi had been referred, M. de Lantsheere moved a resolution which at once revolutionised the situation. He proposed that a temporary subsidy should be voted for the purpose

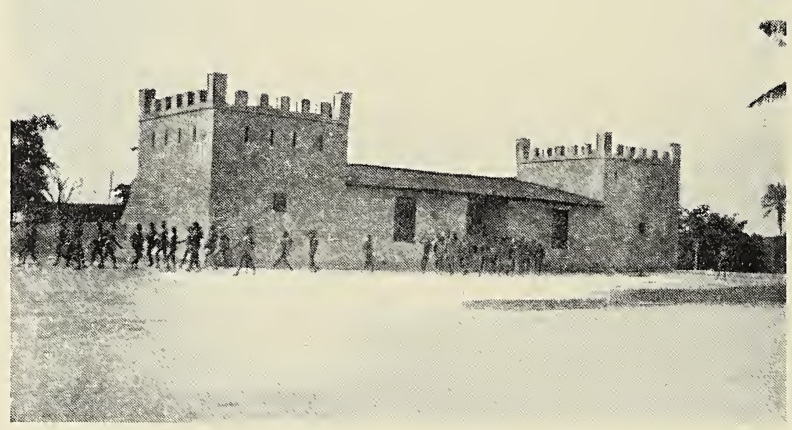

PRISON, BASOKO.

of relieving the financial embarrassment of the State, and this was received with general favour as offering a means of escape from what threatened to be a somewhat dangerous situation. The Foreign Minister having resigned, the Government immediately proposed a subsidy of 5,600,000 francs, and this was promptly voted by the Chambers, it being understood that discussion of the question of annexation should be postponed until January, 1901, as originally suggested in the Convention of 1890 .

Though the time-limit specified in the Convention expired on the second day of the year, the Belgian Government allowed several months to elapse before challenging a vote of the representatives of the people. The general question was 
in the first instance referred to a Parliamentary Commission, and to it, among other proposals, was submitted a draft Bill, which had been adopted by the Home Government on behalf of the Congo Free State, declaring that "the reimbursement of the sums lent to the Congo State in accordance with the Convention of the $3 \mathrm{rd}$ of July, 1890, and by virtue of the law of the 29th of June, 1895, as well as the payment of interest accruing on these sums, is suspended," but that, "should Belgium renounce its option of annexing the Congo State, the financial obligations incurred by that State by reason of the aforementioned Acts will take effect." These somewhat vague proposals were, however, subsequently modified by a project,

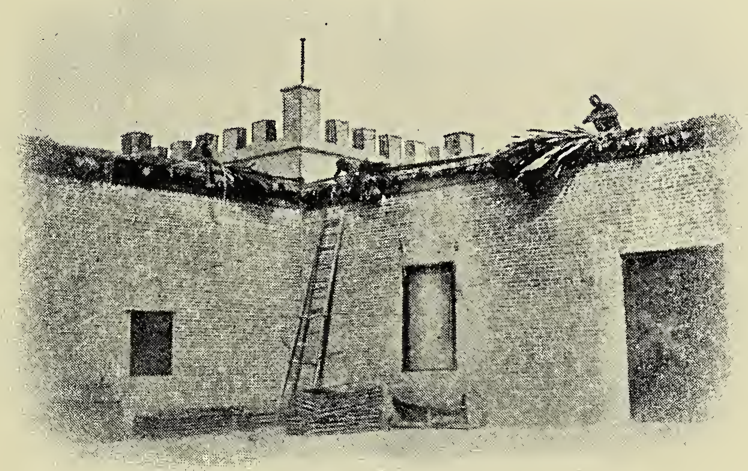

INTERIOR OF PRISON, BASOKO.

submitted by the Prime Minister, to renew for another ten years the Convention of 1890 , without payment of the loan or interest, and without provision for the better management of the State or its ultimate future. After considerable controversy over this and other proposals and the suggestion that the Belgian Parliament had already surrendered, by its action in 1895 , the right of annexation assigned to it five years previously, M. Beernaert introduced a definite measure for the union of the two States. His Bill declared the territories of the Congo Free State to be, by virtue of the Convention of 1890, "henceforth the property of Belgium, together with all prerogatives, rights, advantages, and sovereignty attaching 
thereto." The measure further proposed that Belgium should assume all the responsibilities of the State towards third parties, but that two years should be allowed for the preparation of a "special régime," legislative, administrative and judicial, for the new possession, and that "during the said two years, the administration of the territories shall be carried on under the same conditions as at present."

Although obviously intended as a compromise, this Bill failed to command substantial support; on the one hand, it lacked the sympathies of the more advanced of the Belgian Liberals, who had never disguised their objections to the complicity of their country in the methods of the Congo State, and, on the other, offended the King, his coadjutors in African adventure, and the trading monopolists by allowing them only two more years for the acquisition of wealth. So seriously was this provision regarded that, on the 11th of July, Leopold II., as Sovereign of the Congo State, addressed a letter to the Special Commission, in which he said :-

"If annexation is actually voted before the time arrives when the State is able to assure to Belgium all the advantages which I desire should accrue to it, the Congo administration will naturally refuse to participate in a hybrid government, which, in reality, will be mere chaos, and can only produce, both internally and externally, friction and loss. Is it conceivable that a State can be annexed, and yet be compelled to carry on its government ad interim? For it must be acknowledged that Belgium is not ready for such a step, and is at the moment unable to provide a substitute for the present administration."

Faced with this remarkable interference with parliamentary liberties, and threatened with chaos in the territories of the Congo unless those now ruling were allowed continued and absolute control, M. Beernaert and his friends made haste to withdraw their proposals, the Premier's Bill being then adopted, together with a new clause confirming Belgium's right to the reversion or inheritance of the Congo State.

This issue of the controversy must be regarded as disheartening, not only by those persons whose consciences are uneasy because of the notorious maladministration of the Congo 
State, but by all who wish well to Belgium. The latter was afforded a very favourable opportunity of demanding that the Congo State in the future should more effectively recognise its treaty and moral obligations. Instead of taking such advantage of the occasion, the Belgian Parliament has allowed itself to become party to a compact which largely increases the nation's responsibility for the acts of the Congo Administration, and at the same time debars it more absolutely than heretofore from any exercise of control. It has practically endorsed the breaches of faith and of the moral law of which the Congo State stands convicted at the bar of public opinion, and it has greatly added to its risks of national bankruptcy and of being involved in European complications. When the day of retribution dawns, as come it must, for the many sins of omission and commission of their monarch and his fellow-speculators, the Belgians will find it no easy task to meet the charge of aiding and abetting. It will then be idle to plead that they have but followed precedents; that the exploiters of Africa-of probably every nation-have much to answer for. This is unhappily true; no people can, without hypocrisy, point the finger of scorn at Belgium; but not the worst can be accused of such systematic, comprehensive, and coldblooded misdeeds as those which, during the past fifteen years, have made of the Congo State a veritable charnel-house. 


\section{CHAPTER XIII.}

THE CONGo FREE STATE AND THE BERLIN CONVENTION.

Prince Bismarck's Prayer-The Powers and King Leopold-The growth of Monopoly-Inception of the Concessionary Companies-Their relation to the State-Where Free Trade is not-The "Protection" of the Natives-Is reform possible?

The basin of the Congo comprises some 800,000 square miles and a population variously estimated at from $8,000,000$ to $27,000,000$. The representatives of the Powers by whose act this vast territory and its people were handed over to Leopold II., King of the Belgians, were no doubt very zealous for what they were pleased to call the extension of civilization to darkest Africa. They also, it may be presumed, believed that the new State was called upon to be one of the chief promoters of the work they had in view. "I pray," said Prince Bismarck, as President of the Berlin Conference, at the close of its deliberations, "for its (the State's) prosperous development and for the fulfilment of the noble aspirations of its illustrious founder." Nevertheless, they took care to impose upon the King and his coadjutors certain. welldefined obligations, the intents of which undoubtedly were to improve the conditions of life of the indigenous population and make the new State more or less common ground for the commercial enterprise of all nations.

Thanks to one pretext or another, the astute Sovereign of the Congo has gained the Powers' consent to the modification of some of these provisions; others have been simply disregarded, while the system as a whole, introduced into the government of the country, is opposed to the spirit, and usually the letter also, of every international agreement. The cloak of philanthropy, donned in order to secure the sanction and protection of the Powers 
during the early exploitation of the Congo basin, has now, in great measure, been thrust aside or ostentatiously discarded, and there is at last laid bare to the world a grasping commercial monopoly which has not only succeeded in absorbing every profitable enterprise within its reach, but has, by the unscrupulous exercise of despotic power, outraged every law of humanity and strangled every undertaking not of direct benefit to itself.

It was agreed by the General Act of the Berlin Conference that throughout the Congo basin the trade of all nations should enjoy complete freedom, and that "no Power which exercises, or shall exercise, sovereign rights" within it "shall be allowed to grant therein a monopoly or privilege of any kind in matters of trade." Thanks, however, to an ingenious misinterpretation of another provision of the Act and to the modification of the original restrictions sanctioned by the General Act of the Brussels Conference of 1899-90, the Congo State has been enabled to set in action elaborate machinery of tariffs and prohibitions which places at its mercy and that of subordinate monopolies all present and possible competitors. By Article 14 of the Berlin Act it was provided that "there shall be levied no maritime or river toll based on the mere fact of navigation, nor any tax on goods aboard of ships; there shall only be levied taxes or duties having the character of an equivalent for services rendered to navigation itself." Moreover, the said tariffs "shall not involve any differential treatment," and all affluents of the Congo, and all roads, railways or lateral canals "which may be constructed with the special object of correcting the imperfection of the river route shall be considered as dependencies of this river, and as equally open to the traffic of all nations; as on the river itself, so there shall be collected on these roads, railways, and canals only tolls calculated on the cost of construction, maintenance, and management, and on the profits due to the promoters." It is unnecessary to more than quote these very elastic provisions of Articles 14 and 15 to show how ingenious manipulation has converted them into weapons against the very spirit of the Act. Their scandalous misuse had already, in a measure, been exposed when the second Conference-professing even greater philanthropy than the firstcompleted the wreck of all true progress in Central Africa. Summoned with a view to the repression of the slave-trade and 
other evils, its greatest achievements were: (1) to sanction a 10 per cent. ad valorem duty on all goods imported into the Congo State; (2) to strengthen the latter's monopoly; and (3) to endow with the blessings of the civilized world the expeditions against the pseudoArabs of the east which, as I have sought to show in other chapters, imposed upon the unfortunate peoples of the Province Orientale worse forms of tyranny than they had ever heretofore experienced.

"To assure to all nations the advantages of free navigation," and to further "the moral and material well-being of the native populations" were, as regards the Congo, the prime purposes

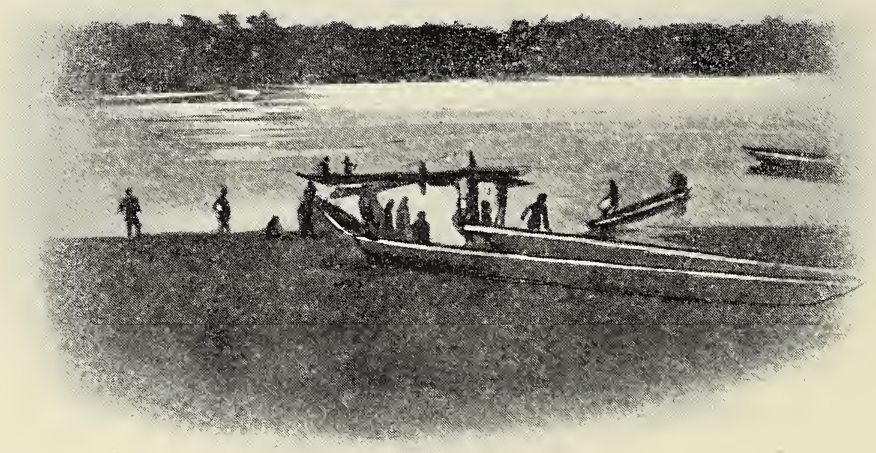

BASOKO CANOES.

of the Berlin Conference. In this chapter I propose to show how fatuous were the Powers in imagining that the first could ever be secured through the instrumentality of King Leopold, and how that monarch has succeeded in converting a so-called "free-trade zone" into an organisation of which monopoly, direct or indirect, is the all-pervading characteristic. So far as the white trader is concerned, this is a comparatively unimportant matter, for the Congo State, though large, is not all the world, and he can always seek markets elsewhere; but to the natives it is nothing less than a question between death by slaughter or starvation, and an even more miserable life of cruel slavery and continuous spoliation. 
Much has been written at various times concerning the Domaine Privé, but it is difficult for any person who has not travelled in the Congo to appreciate what these words signify to its wretched inhabitants. Ostensibly a measure for protecting the blacks against lawless intruders, the decree of the 1st of July, 1885, was really the first step towards declaring the natives outcasts in their own country and practically depriving them of all use of its lands, except for the benefit of the State or its chartered deputies. This was followed by other decrees, all in the same direction; for instance, on the 30 th of June, 1887 , all lands in which private property

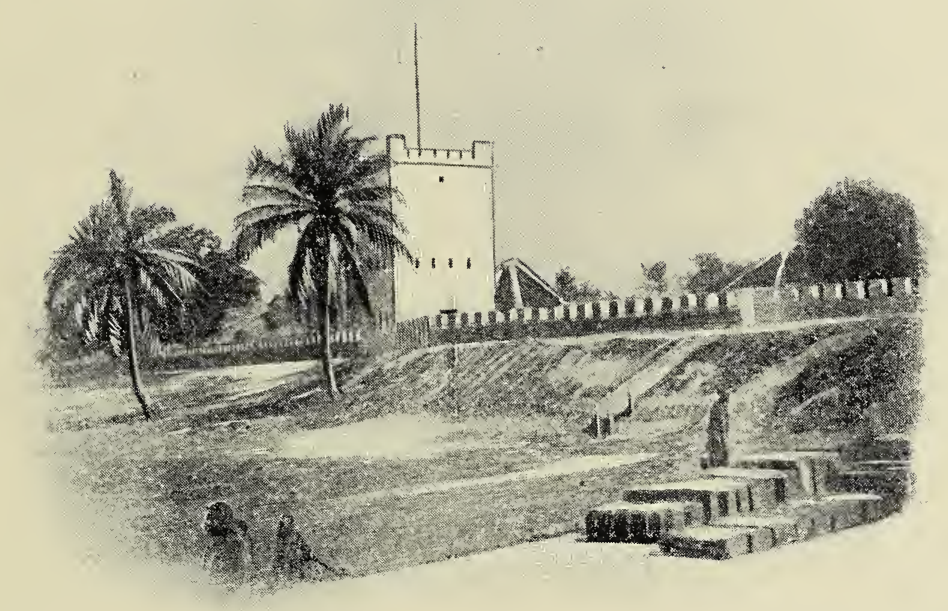

TOWER OF BASOKO.

had not been "recognised" were declared "terres domaniales," ("un domaine privé de l'Etat"), in which no wood might be cut, minerals extracted, or other undertaking of any sort entered upon without license from the State; on the 25th of July, 1889, elephanthunting and ivory were constituted monopolies of the State, "unless by special license"; and on October 17 th of the same year it was further provided that " the procuring of rubber, gum-opal, and other vegetable products, in the districts where these substances are not at present procured by natives, and which constitute part of the State domain," should be included in the 
monopoly of the State and its "concessionaires." All these arrangements, it must be obvious, were in direct defiance of the Berlin prohibition of " monopoly or privilege of any kind."

Even more scandalous, however, has been the grant in absolute monopoly of some of the richest sections of the rubber-producing forest to companies from the profits of which the State-in other words, King Leopold and his financial allies-have drawn a large percentage. The astute Sovereign was quick to recognise, first, that it would be impossible for the State, unaided and in a measure hampered by its administrative duties, to effectively exploit the country during his own and possibly its lifetime; and, secondly, that no private enterprise, unless carefully buttressed with exceptional privileges and the direct support of the Government, would be able to withstand the latter's taxation. To these considerations we owe the inception of these monopolist concessionary companies of the Congo, whose very names are now bywords of scorn among all men with whom the voice of conscience lingers, more potent even than the lust of gold. Of these companies, great and small-Belgian, Dutch, and Portuguese-there exist, and have hitherto flourished, many scores; but to only few of their number is it necessary to here specifically refer. These have for a long time enjoyed, in a very special degree, the direct support and patronage of the State; and from their careers of continual crime and massacre the State has derived substantial pecuniary benefit. Many ingenious attempts have from time to time been made by King Leopold's apologists, Belgian and British, to explain away, as quite accidental, the connection between these circumstances, but, needless to say, without great success.

Take, for example, the Société Anversoise du Commerce au Congo, founded at Antwerp in August, 1892, with a capital of 400,000 francs, subsequently raised to $1,700,000$, with $M$. de Browne de Tiège-a financier not unknown to the King-as president, and the notorious M. Lothaire as managing director at Mobeka. This company secured for a renewable term of fifty years concessions of the rubber-producing forests and all the lands of the Domaine Prive in the basin of the Mongalla, with the exclusive right of exploiting all their products, and for these 
monopolies undertook to pay to the State special royalties amounting to 300 francs for every 1,000 kilogrammes of rubber gathered, 150 francs for the same quantity of wax or copal, and five per cent. of their value in the markets of Europe for ivory and other products. In 1898, the year of its reconstruction with larger capital, the Société Anversoise declared its profits at $3,986,832$ francs, equivalent to nearly 235 per cent., representing -and on this point I can speak with authority second to no onethe forced and almost uncompensated toil of the indigenous populations, and the blood of thousands of men, women and children murdered by brutal agents and their cannibals employed for the purpose of "trading." Consider, also, the case of the Anglo-Belgian India-Rubber and Exploration Company, the now notorious "Abir," which has had a record scarcely less scandalous than that of the "Mongalla" Company, and equal financial success. This was founded at Antwerp four days later than the Société Anversoise, with the late Colonel North as president and a capital of 1,000,000 francs; and its profit returns in 1898 were 2,782,697 francs, or more than 248 per cent. The "Abir" obtained the absolute ownership of all the lands of the Domaine Privé in the basins of the Lopori and Maringa (about 470 square miles), and, in addition, the right for thirty years of exploiting all the products of the forest. For these concessions the State has exacted one-half the annual profits. Pretty much the same story has to be told about the Compagnie du Lomami, operating on the Lomami River from its mouth to Bena Kamba; the Société d'Agriculture et de Plantation au Congo, whose field of action extends to the left bank of the Congo, above and below the junction with the Lomami; the Société Equatoriale, with headquarters at Equateur; the Comptoir Commercial Congolais, with concessions in the basin of the Wamba, an affluent of the Kwango; the Société de la Djuma; the Société Agricole du Lubefu; the Société Kassaienne, and many others, whose very existence is an insult to the Powers signatory to the Berlin Act.

Nothing is needed to prove that the Independent State of the Congo, so far from being free to all, has become a huge network of monopolies. Neither in the Domaine Privé, which includes nearly all the rubber-producing regions not gifted away, for considerations, to the concessionaires, nor in the territories handed over to the 
latter, can an independent trader buy a pound of rubber or an ounce of ivory, or sell a spoonful of beads or an ounce of brass wire. The State fixes the price of the products which the natives are compelled, at the muzzle of the Albini, to bring to its posts; and it is scarcely necessary to add that the price so fixed is absurdly near to nothing. It may not have been guilty of all the crimes of the Mongalla Company-concerning this, however, I am more than sceptical-but it is at least significant that, whereas the Budget of 1891 took credit only for 142,000 francs on account of domain produce and imposts paid in kind by the natives, that for

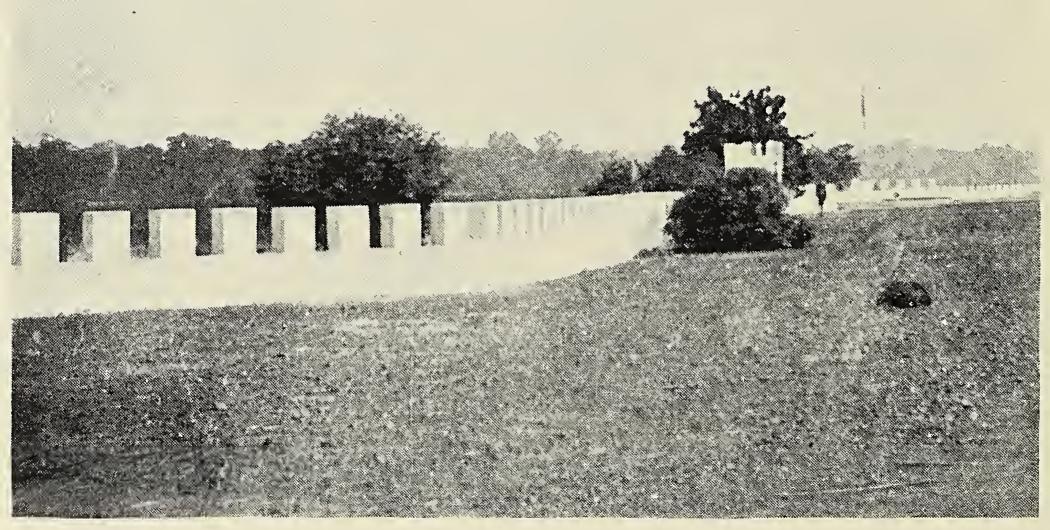

RIVER FRONT, BASOKO.

1898 admitted from these same sources no less than $6,700,000$ francs. I at least am sufficiently well acquainted with the Bantu to recognise that this 47 -fold increase has not resulted from equivalent zeal for rubber gathering or augmented appreciation of the blessings of Belgian rule.

Apologists for the Congo State and its treatment of the natives-the worst of institutions can always depend upon some champions, either short-sighted or self-interested-never tire of dilating upon the "measures" adopted by the Government at 
Boma to check admitted abuses. They point with great pride to the instructions issued in September, 1896, for the guidance of the State agents in their dealings with the natives; to the appointment of M. Michel at the same time as State Inspector to see that these instructions were carried out; and, above all, to the fact that by a decree dated the 18th of September, 1896, the philanthropic Sovereign instituted a permanent Commission charged with the protection of the natives throughout the territory of the State, and that this Commission (reverend gentlemen all) has never, or, to be strictly accurate, very seldom, reported that anything

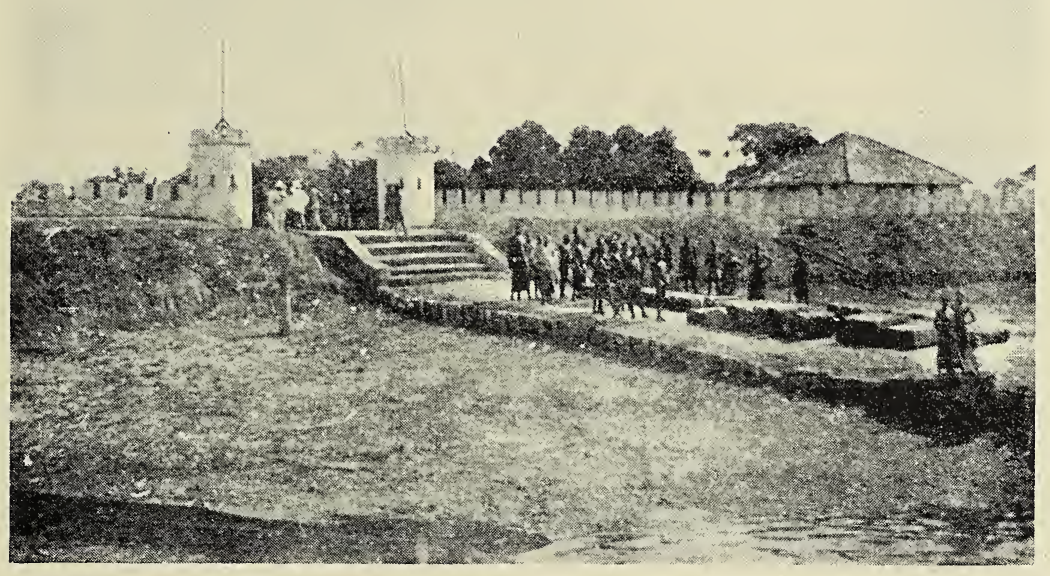

ENTRANCE FROM THE RIVER, BASOKO.

was wrong. To all these things the "Bulletin Officiel" of the State (12th year, pp. 253-259) bears printed witness; but to what practical end? This question has been already answered in these pages, and notably in the chapter entitled "The Massacre of the Gwakas," the principal incidents in which cannot be unknown to the Boma authorities, their State Inspector, or even much-vaunted Commission. Of the last mentioned, and, indeed, of the missionaries generally, I desire to speak with all respect; but it is essential to point out that the 
reputation of some few of their number has not always been above suspicion; that as a class they are very dependent upon the goodwill and assistance of the authorities, and that, therefore, they cannot be expected to go far out of their way in criticism of the Administration. When confronted with charges which cannot be conveniently ignored, or met, as is usual, with platitudes and a bare contradiction unsupported by proof, the State has very ingeniously shifted the guilt upon some subordinate company agent. Not without full appreciation of the gravity of the statement do I say that there has not been a single measure adopted for the protection of the natives which can be fairly described as serious, much less effective; nor do I believe that anything better can ever be anticipated from the Congo Government as at present organised and administered.

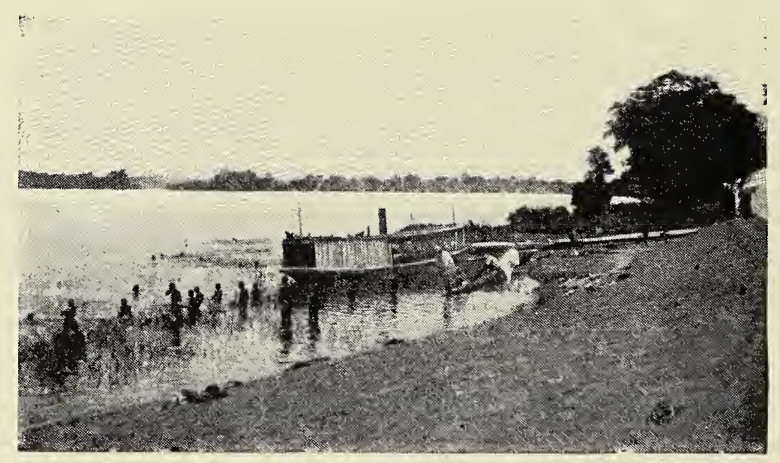




\section{CHAPTER XIV.}

\section{CIVILIZATION AND CANNIBALISM.}

Europeans $n$ the Congo State-Missionary Efforts-The Chief, the Fetish Doctor, and the "Poison Proof"-A Gang of Cannibals-An Execution at Ponthierville-The Traffic in "Man-Meat"-The Fetish Power.

IN the year 1896 the total European population of the Congo State was 1,678, and of these only 670 - the number is probably smaller to-day-lived in the Upper Congo, properly so called; that is to say, all the territory lying to the east of the longitude of Stanley Pool. Of these 670 Europeans, probably half were traders and the remainder agents of the State employed, incidentally, in the administration of the country. Thus 335 white men, many of whom were ill-informed corporals and sergeants of the Belgian army, whose services could not be utilized for much else than military instruction in the camps at Zambi, Bolobo, Irebu, and Umangi, were expected to efficiently administer. a country some 700,000 square miles in extent, and containing a native population variously estimated from $7,000,000$ to $20,000,000$. These white officials are stationed in some fifty Government posts, each of the latter the administrative centre, so to speak, of 14,000 square miles more or less. To properly administer such a country under existing conditions is clearly a physical impossibility, especially when it is remembered that some of the posts contain but a single white man, and that comparatively few are occupied by more than three.

Truth to tell, King Leopold and the Congo clique have never made any really earnest effort to civilize the Congo savages, for civilization, as generally understood, would mean free commerce, resistance to despotic rule, and other serious impediments to the continued maintenance of a strict monopoly. The little light that 
has penetrated the African jungle is primarily the result of missionary effort, and, outside the immediate sphere of such work and the military and trading posts of the white man, no change among the aborigines is observable, except here and there a scrap of cloth covering the nakedness of the savage. Of the adult representatives of the Congo races no hope can be entertained. It is to the rising generation that we must look for possible advancement; and this view apparently has been accepted by the missionaries, for they are devoting the largest share of attention to the instruction of the young. The number within the pale of their influence is, of course, small in comparison with the total population, for the efforts of the missionaries, in a field of such dimensions, must necessarily be restricted by the means at command. Unhappily, it cannot be expected that the ruthless massacre of parents and brothers by the soldiers of Bula Matari will be promptly forgotten, or that the younger negroes will be otherwise than unfavourably impressed by civilization as represented by many of King Leopold's rubber-hunters. The people of central Africa, like the majority of aboriginal races, are quick to acquire the vices of the white man, and the few virtues the latter ever displays to them make but little impression; they know him generally only as a hard, unpitying taskmaster.

As affording evidence of the painfully slow progress of civilization in the heart of Africa, I may cite a personal experience while stationed at Lokandu (Riba-Riba), a State post in the Province Orientale. One Sunday morning, while seated on the verandah of my clay house, taking advantage of the unusual quiet to read the "latest news" from a bundle of journals quite two months old, my attention was attracted to a small native boy weeping bitterly before me. At first I took no notice of him, being accustomed to the usually petty grievancies which the natives, whenever in the least encouraged, were ready to pour into my ears. As, however, he continued crying, I finally asked him what was the matter.

"My master is going to kill me," he answered.

The reply suggested an interesting story, so I bade the lad sit in the shade of the verandah, and gradually he disclosed the causes of his distress.

Kilongalonga was a chief of the Wagenia village on the bank of the Lualaba opposite to the State post. His brother, it appeared, 
was suffering from a great ulcer on the leg, and had declared himself bewitched. For no reason that I could ascertain, some of the women belonging to Munyumbi (also a Wagenia chief, whose village stood on our side of the river and only a musket-shot from my house) were suspected, and it was consequently decided to call in the fetish-doctor and, by means of the "poison-proof," unearth the guilty ones. The custom referred to, and common

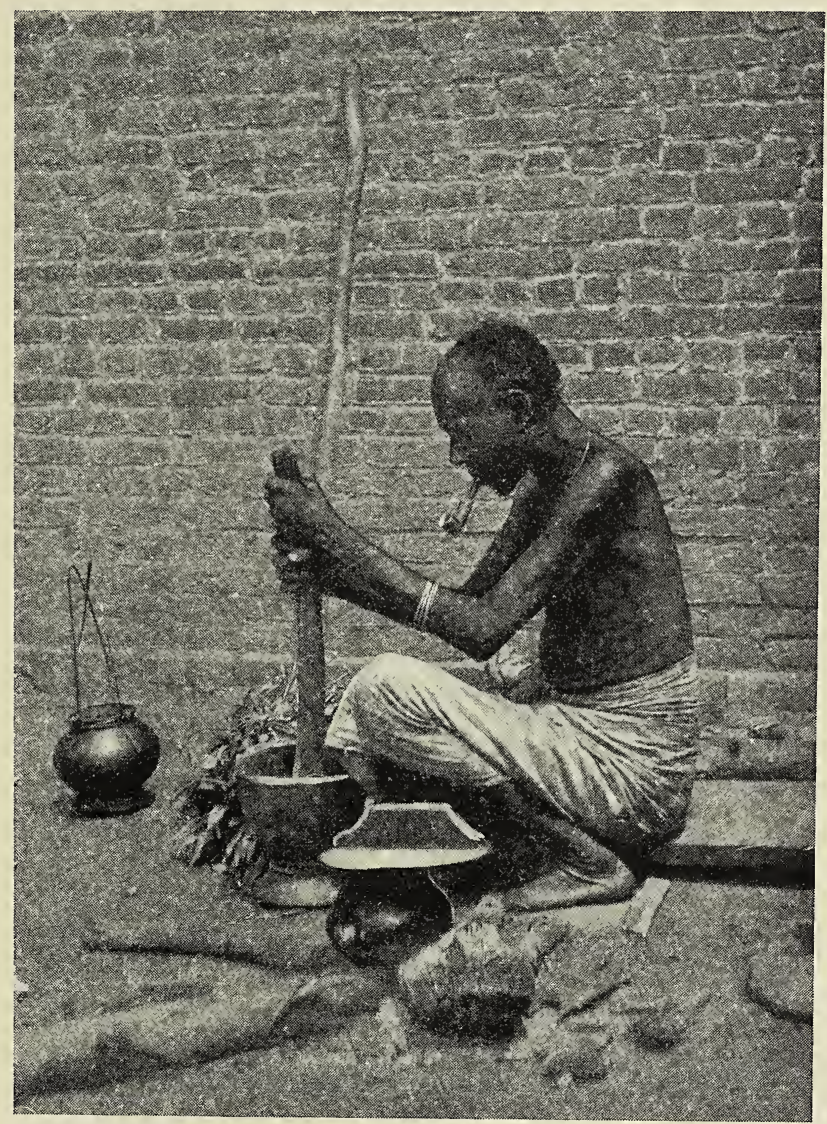

JO OF OLD BASSAM, PRISONER AT BASOKO.

enough among the African tribes, consists in administering to suspected persons a draught, the composition and proper preparation of which are represented by the fetish-man to be great secrets. It is, however, merely an infusion of not very rare jungle herbs and bark, which, when taken in sufficient quantity, will cause death. 
In cases of trial by poison, should the accused survive he is, of course, held innocent of the charge against him, whereas death is regarded as certain proof of guilt. At Munyumbi, therefore, there prevailed little doubt of the efficacy of this means of establishing the truth, for seven women had died, while several others had escaped merely with an illness. The former, in accord with local ideas, strengthened probably by a long-felt want of meat, were now adjudged most certainly guilty of having caused by witchcraft Kilongalonga's brother's sore.

The fetish-doctor having thus disposed of much valuable property-for the natives assess their wealth by the number of women slaves they possess-all interested in the affair should have been fully convinced that the demon which had entered the leg of Kilongalonga's brother had been duly exorcised. Kilongalonga, however, was yet sceptical, and deemed it essential to further appease the evil spirit by a sacrifice-and incidentally provide a meal for himself and his cronies.

Fortunately for the boy, he became acquainted with the fact that he had been selected as the pièce de résistance of the intended banquet, and accordingly promptly took passage in a canoe and hurried to the station. Here he hid during the night, and in the morning summoned sufficient courage to come and see me. Having satisfied myself that there was at least some foundation for his story, I told him to keep quiet, and ordered my "boys" to hide him until nightfall in a small hut at the rear of my house. As no one had seen him speaking to me, I flattered myself that suspicion would not enter the minds of the gang of cannibals.

Shortly before nightfall a party of soldiers, disguised as members of an Arab band, silently crossed the river by canoe, while another posse proceeded by a jungle path to the rear of Munyumbi's village. The fetish-doctor, I had ascertained, lived at a village some two hours distant on the other side of the river, and consequently my people were instructed to make no arrests before early dawn, in order that the man charged with the doctor's capture should have ample time to reach his quarry.

Early in the morning the soldiers returned, each with a prisoner. They had done their work well, the result, no doubt, of some prior knowledge of the cannibalistic proceedings. On the previous evening, before dismissing them to their task, I had 
asked the corporal if he knew anything of what had taken place. He replied that he had heard about it, whereupon I inquired why he had said nothing to me on the subject. The answer was at once characteristic and suggestive. He had not thought of it, he remarked; and moreover had not considered that I would care to know, for the same thing had often occurred in the neighbouring villages, and the white men at the post had never bothered about it. I, of course, rated him soundly, and gave all the soldiers to understand that it would be my special business to "smell out" the witch-doctors who made it theirs to "smell out" witches with fatal results.

The prisoners were duly ranged up before my house, and a sorry lot they looked. I had the boy brought forward, and he indentified all but one man, proved to be a slave, who was released. They were then securely chained together and sent to bask in the warmth of the fire at the brick kiln, which occasionally served also as a prison. The fetish-doctor had arrived resplendent in a huge monkey-skin cap ornamented with red parrot feathers. He also carried an earthen pot, in which was a greenish liquid. The latter he had brought as a sample of the poison to show how harmless it was; but I happened to know that the colour of the genuine article was grey, and therefore had little difficulty in exposing the attempted fraud.

In the preliminary investigation which followed, the facts were established substantially as the boy had stated them. There was, however, no direct evidence against any of the prisoners except Munyumbi and the fetish-doctor, who were held on a charge of murder. They not only admitted their guilt, but apparently failed to see anything heinous in their offence. Nevertheless, it was recognised that here was a fitting opportunity of making an example. Accordingly the chief and the "doctor" were brought before a court-martial at Ponthierville, the headquarters of the zone, found guilty of murder and cannibalism, and sentenced-the former to be hanged, the latter to a long term of penal servitude. Munyumbi was duly executed at Ponthierville, but the effect was entirely lost, for, thanks to the mischievous system much in vogue in the Congo of punishing natives far from the scene of their crimes, scarcely a soul in the Lokandu district ever heard of his fate. The boy who had proved the undoing of the chief and the 
witch-doctor was confiscated, and became a servant to one of the white men up the river.

The post of Lokandu has been established fully seven years, yet so little moral impression has the presence of white men, the representatives of civilization, made upon the natives that the latter continue their barbarous customs almost within the station's bounds; and practically the same may be said of all the posts above

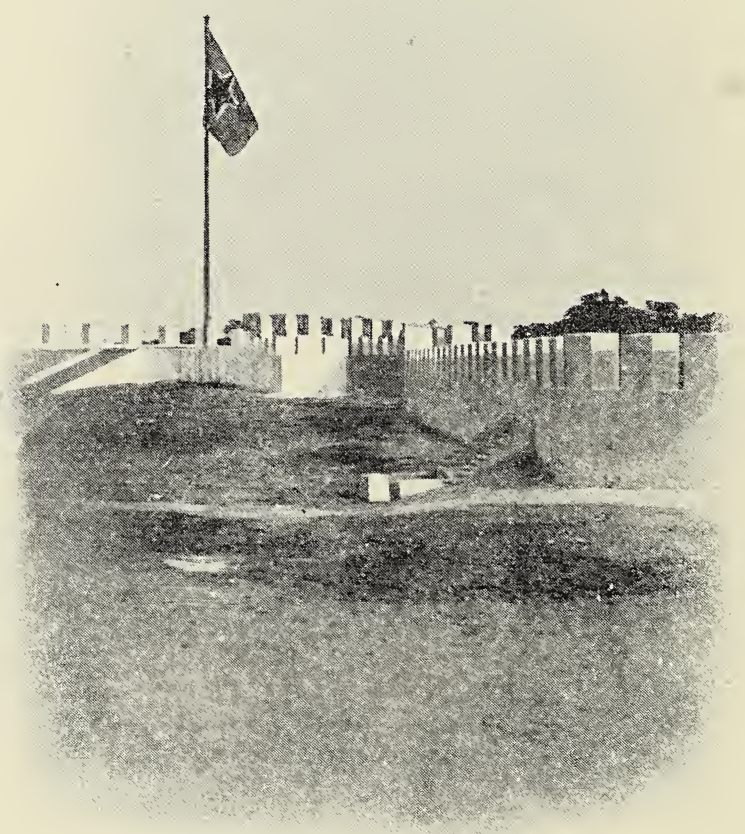

FORTIFICATION AT BASOKO, LOOKING WEST.

Leopoldville. In some parts of the Mongalla, the ancient traffic in slaves for the shambles flourishes unhindered. At a village called Bokanga, near the mouth of the Mongalla River, we were well aware that scores of slaves were being sold to supply meat to the people on the other side of the river. They were smuggled up a small creek called the Dolo, in the neighbourhood of which the consumption of man-meat was said to be enormous. Neither the State 
nor the companies use their Albinis for the purpose of suppressing the traffic ; the Albinis are in Africa to "produce" rubber, and for little else.

Nothing has been done by the Government with a view to dispelling the dense ignorance and superstition of the natives. I have, when traversing the villages of the tribes among whom I have been, seen frequent illustrations of absolute barbarism.

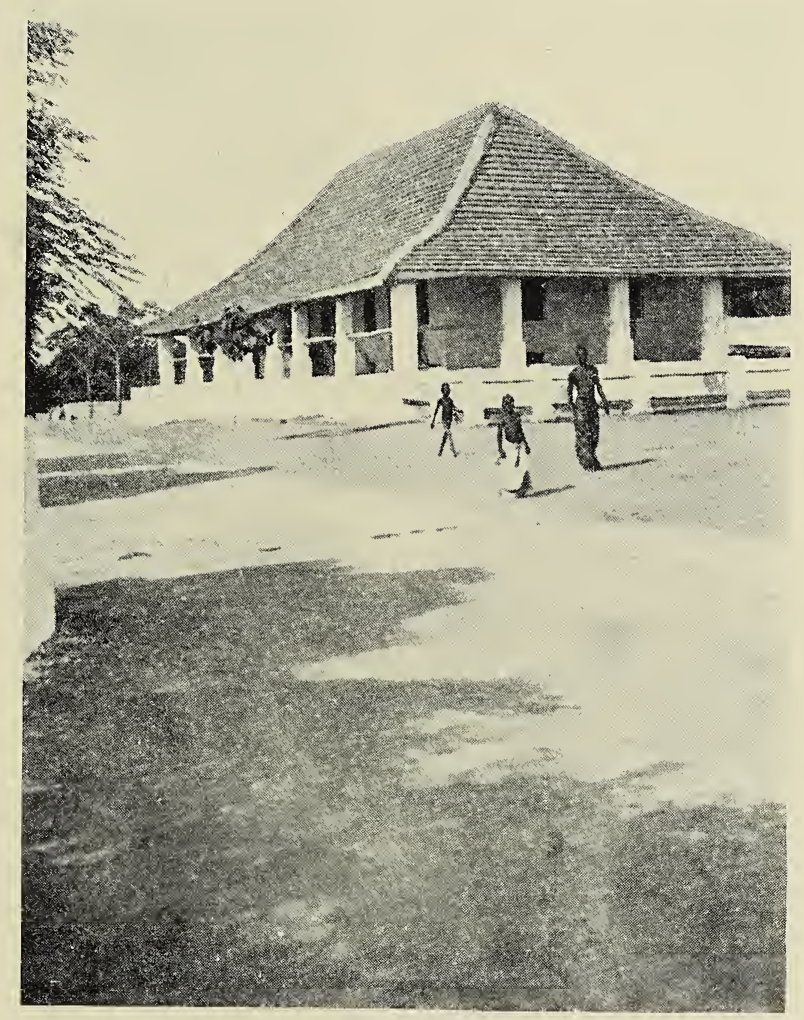

CAPT. BURROWS' HOUSE, BASOKO.

Generally speaking, and epecially in the Mongalla region, the people are quite as uncivilized as they were when Stanley made his famous descent of the Congo, save that they are more chary of attacking the white man. In or near many of the villages may yet be seen the "execution grounds" described by an earlier traveller in these regions. A stout sapling is planted in the earth, the slave destined for the cooking-pot is made to kneel, and 
the sapling is bent down and attached with a cord to the head of the victim. When the executioner's knife descends, the sapling reverts to its upright position, causing the severed member to fly high into the air.

The fetish power is as strong among the natives as ever it was. It is true that near the stations these things are kept as secret as possible from the white man, and it is generally only by chance that he hears of them. When passing through the villages I have frequently seen, stuck upon poles on each side of the road, earthenware pots containing mono, or medicine, the object being to prevent the entry of evil spirits. In the plantations the natives often put mono, in the shape of wild forest fruit, upon stakes to secure good crops and warn off thieves. There is an endless variety of superstition among the Africans which, at the rate of progress hitherto made under the sway of the speculators, it may require centuries to eradicate.

Among the riverside tribes, who live chiefly in their dug-outs for months at a time, fishing and curing their fish, regular rules of etiquette concerning the disposal of their dead friends exist. If in two villages, say a quarter of a mile away from each other, any member of one community dies, the body is promptly placed in a canoe and taken to the other village, where it is handed over to supply a banquet for the chief and his friends. The compliment, of course, is returned when a member of the other village likewise fulfils the debt of nature. Quarrels between villages are frequent, generally ending in a settlement by force of arms. Two or three men being killed on each side, peace is restored, and preparations promptly made for the ensuing banquet, each side taking over the slain of their opponents to furnish the feast. That the native thinks there is no harm in cannibalism there can be no doubt. It comes as natural to him to eat the flesh of a human being as it does to Europeans to eat beef or mutton; and he certainly emphasises the point that the flesh of man is superior to that of other animals. He prefers that of the white man to the black, because Europeans are accustomed to the habitual use of salt, which of course the native does not use. A curious incident occurred to myself as regards these banquets. Two villages having quarrelled, agreed to settle their differences with a friendly fight; they proceeded to business, with the result that four men on 
one side were killed and two on the other. Peace being declared, inquiries were instituted to ascertain the number of dead on each side. When it was found that the proportion was two to four, the village losing the greater number promptly claimed two more victims to equalize the account. It was agreed to refer the matter to the arbitration of the white man commanding the post, who naturally informed them that they must abide by the result of the patched-up peace. These chiefs, being much disgusted with the result of this appeal to the justice of the white man, waited until my arrival to again place the matter before myself, hoping that the former verdict would be reversed. Their disgust was only increased when I informed them that, in the event of hearing of any further disputes being settled in a similar manner, the chiefs on both sides would be severely punished and the villages heavily fined. That the influence of the Belgians over these customs is but small is proved by the fact that for over seven years a white man's trading post had been established between these two villages, the chiefs and natives of which were in daily and constant contact with the white.

On another occasion, at the same place, the chief of the neighbouring village arrived to see me, attended by twenty of his men, each of whom carried a gun in one hand and a carefully preserved skull in the other. On inquiring the meaning of this demonstration, I was informed by the chief that he had only come to visit me in order to prove to me his loyalty towards the white men. The reason of the skulls being brought, together with the guns, was to show me that he was not in the habit of selling his guns in exchange for women of the tribes of the interior-a habit very common with riverside tribes. The skulls, which he explained were only a small sample of what he had in his village, all belonged to the tribes of the interior, the majority of whom had been eaten by himself and family. On asking for information concerning the manner in which he obtained these men, he explained that from time to time an inland man was caught in the neigbouring bush, and occasionally these were obtained by raiding an enemies' village when they themselves were attacking some other tribe. I asked him how long it took him to eat a man. "That depends," was the answer, "if he is a personal enemy or not." I asked what difference that made. "Oh," he replied, "that makes a 
lot of difference. If he is a personal enemy, I eat him all myself; but if he is only an ordinary capture I allow my wife and family also to partake." He also explained that if his wife and family shared the repast, the body was consumed in one day, but that if he was the sole consumer it would take him about two days, according to the size of the man.

Amongst the chiefs with whom I was brought into contact was Moimba, the head chief of Basoko, who was distinctly a person

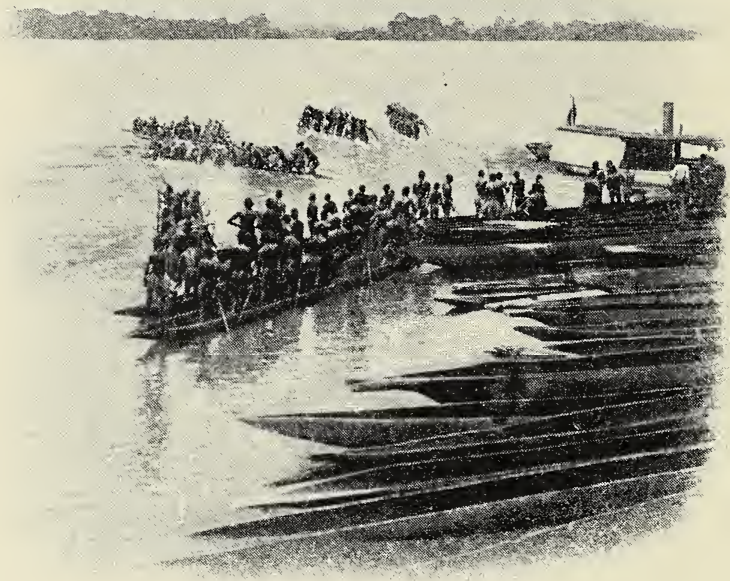

CANOE RACE, BASOKO.

with a past. On Stanley's voyage through Africa, when he discovered the resources of the Congo, this chief was one of the leaders of the attack made upon his flotilla when passing the mouth of the Aruwimi. After this, Moimba took a considerable part in the destruction of the State outposts, and the consequent killing and eating of the Haussa soldiers therein. I should not like to be Moimba if Moimba has a conscience, though I do not 
think that it troubles him much. He is now the nominal head of the Basoko people, and has a very fair idea of his own importance as such. He daily came to visit me when I was at the headquarters station, and invariably with the demand for a drink. His idea of a drink was distinctly peculiar. Accustomed as he was to the bittersweet native palm wine, he nevertheless preferred European drinks well seasoned with red pepper. I have seen this man drink a mixture of absinthe, claret, and whisky, filled up with two spoonsful

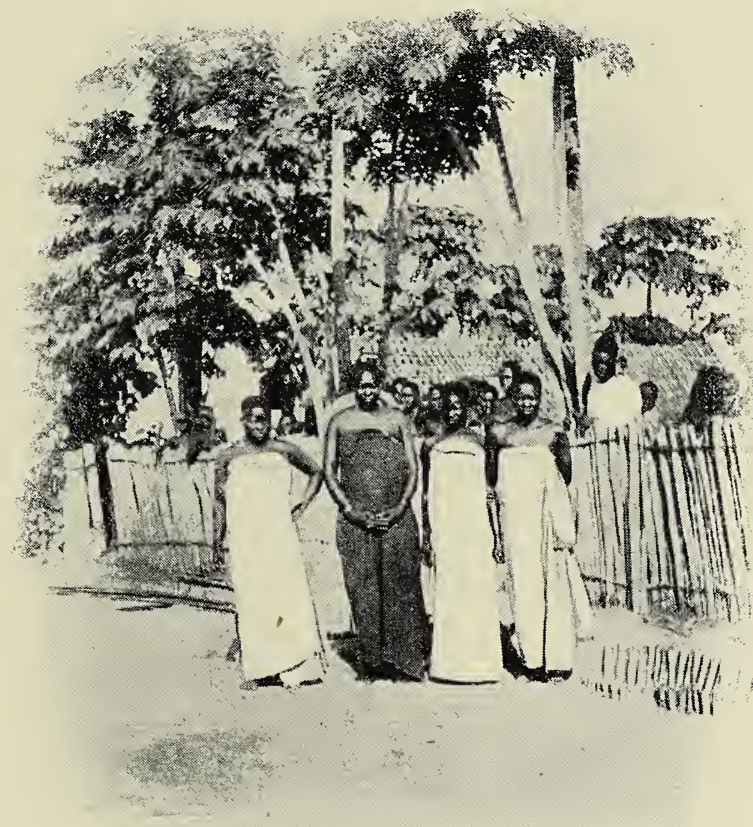

WORKWOMEN OF BASOKO.

of red pepper and a lump or two of sugar. A tumbler of this mixture he would drink off as we should drink a glass of water. The pepper remaining at the bottom of the glass he would carefully scoop out with his forefinger and swallow. He was never satisfied with one, and invariably demanded a further potation. I doubt if anything could have made him drunk. As paramount chief he invariably attended all the markets within reach, where palm wine 
was always sold in large quantities. He exercised his rights by sampling every pot of wine which appeared in the market for sale, and he arranged his own sampling-regulations in accordance with his thirst. This man must be over fifty years of age, though it is impossible to correctly judge the age of a native after he has passed middle life. His numerous wives caused him a considerable amount of disquietude, and he was constantly coming to the station with demands that he should be allowed to have two or three soldiers to go to some village in order to bring back one of his wives who had left him for a younger lover. He is now, to all intents and purposes, reconciled to the rule of the European, more from force of circumstances, perhaps, than from any desire of his own.

The Administration of the Congo Free State professes great anxiety that marriages should be performed according to the legal code in force among the natives, whether soldiers or workmen, and the men in State employ. The rules regarding these marriages are set forth in full detail. In my administrative capacity I frequently had to perform the rites of marriage amongst these people. Morality, fidelity, and the responsibilities of the head of a family had to be explained in full detail to the husband and wife. That they understood or comprehended the responsibilities which they undertook is more than doubtful. To quote one instance which came under my personal notice. One day, after due announcement had been posted five days on the public notice-board, I celebrated the marriage between a black sergeant-major (who, by the way, had been brought up by the French Catholic missionaries, and who spoke French fairly well) and the lady of his choice. Before signing the necessary documents, I explained to them in the best way I could the duties incumbent on husband and wife. At the end of my admonition I was, however, much surprised to find that the whole of this sermon had evidently been looked upon as merely a part of the performance. On asking the bridegroom if he understood what was required of him, he replied: "Oh yes," he understood perfectly. The wife, in reply to the same query, opined that she also understood, but she wished to know, if her husband misconducted himself without her consent, what were the penalties attaching to the offence. I explained to her that she could not obtain a divorce under these circumstances, 
but that if she offended, her husband could then divorce her, this being the State law. The lady was dissatisfied, but saw nothing that she could advance on her own behalf. The husband now wanted to know whether he might keep other wives, according to the native custom, without incurring any penalty; and, to make more certain, promised that he would always ask his wife's consent. Eventually they arranged the matter between themselves, and the alliance was duly published by the authorities in the official journal at Boma as a bona-fide marriage, tending to prove, with many other similar cases, the advance of civilization promoted by Belgium in Central Africa. A greater farce in the name of civilization it would be difficult to find.

Native children are not weaned until they have attained the age of two or three years. It is quite a common occurrence to see a young mother carrying on her hip a child three or four years old, and giving it the breast. During the whole time that the child remains with the mother-that is to say, until it is weanedthe husband is prohibited, by custom and superstition, from cohabitation with the mother. Here we have the reason why the Central African native is usually polygamous. I have inquired the reason of the custom referred to, and have been invariably informed that, were it non-existent, the result would be the death of the child. A further reason is, of course, that women perform all the manual labour in the fields and plantations, with the exception of cutting down trees and turning the ground. In addition to this, she always has to look after her children and prepare the meals of her husband. Therefore it follows that the more wives a man possesses the richer he becomes, because he is enabled to put under cultivation a larger area of ground, with the product of which he is able to buy practically everything he requires. The chiefs in the Upper Uelle invariably had a great number of so-called wives. N'yangara, the paramount chief of the Mangbettou, had no fewer than 500, in spite of the fact that he was over seventy years of age. Seventy years of age to a native is practically what ninety years is to a European. These ladies, whose ages ranged from twelve to thirty, all resided in a village built around the principal residence of the chief, and in that settlement no man except the personal attendants of the chief was allowed to reside. The penalty attaching to familiarity with any of these ladies was 


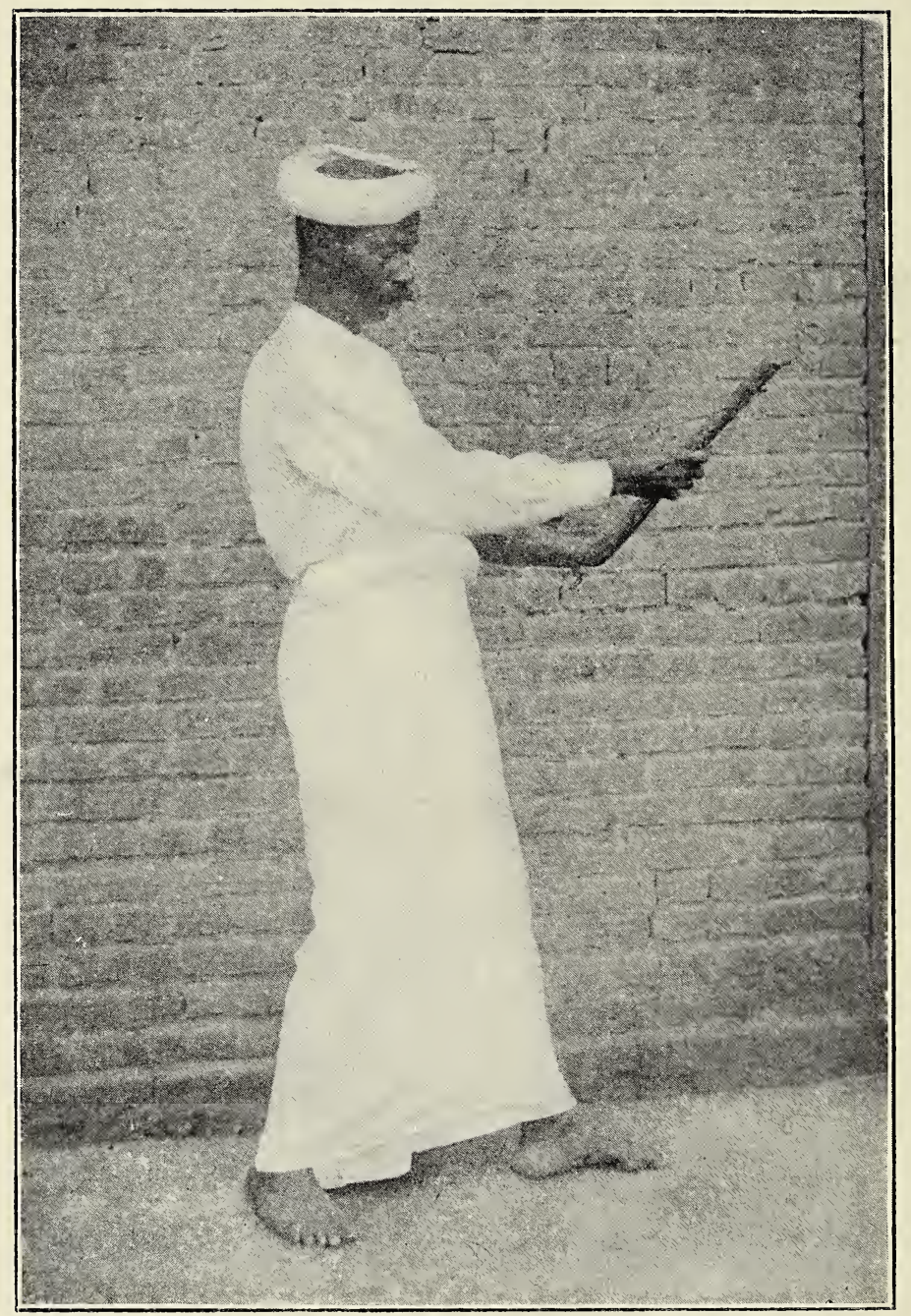

haUSSA PRISONER AT BASOKO (ENGLISH SUBJECT). 
calculated to inspire terror in the mind of any would-be Lothario. Of unhappy consequences, many instances came to my personal knowledge. In one case the Mangbettou chief N'yangara had reason to suspect an intrigue between one of his sons and one of his more useful wives. Apparently, evidence was forthcoming; but be this as it may, before the whole of the chiefs and headmen, the son was brought a prisoner and bound to one of the big poles supporting the huge grass building which served as a council hall. The woman was next produced, and was obliged, on pain of death, to mutilate her alleged co-offender. The trophy was nailed to the erring lady's doorway, where it remained as long as the woman continued to be a member of the community. As a matter of fact, the son thus punished was not the guilty party--it was his younger brother, whom he shielded, and for whom he suffered this terrible punishment. Afterwards forgiven by his father and given several villages to rule over, I frequently met the man, and, knowing the history, was astonished to find that he had several children. On asking for an explanation, I was assured that the guilty man whom he had shielded presented to his self-sacrificing brother every second child born to him.

Another instance of similar character occurred among the Zandé tribe. A son of one of the ruling chiefs having been sent in as an ambassador, I noticed that he invariably kept his arms folded and his hands hidden beneath his cloth. Eventually, however, when handed a pipe of tobacco, he disclosed the fact that both his hands had been cut off at the wrist. Being the son of a powerful chief, I naturally asked for an explanation. He then told me that his hands had been cut off by the command of his father, who had suspected him of an intrigue with one of his wives. Among the Arabs the punishment for adultery inflicted upon the man was, as a rule, dismemberment. The punishment for theft was the loss of one ear. Once I came across a middle-aged man whose eyelids, nose, lips, and ears had been cut off. He told me that this had been done years before, when he was a boy, by the Arabs under the rule, or rather mis-rule, of the Belgian Government and Emin Pasha. The reason why this punishment had been inflicted he declined to state, nor could I learn it from any of the natives in whose village he lived. 


\section{CHAPTER XV.}

The Natives in the Basoko District-Names of the Chief Tribes and their Customs - Burial ; Marriage ; Oracles - Fetish - Anthropology - LanguageWeapons-Customs in War-Cannibals-Feasts-Dances-Music-HistoryRecords.

I HAVE always taken a deep interest in the various customs and manners of the tribes in the districts in which I have happened to be stationed. During my stay in the Uelle district I found it a fairly easy task to gather information on the subject, and there was no lack of material upon which to work. To begin with, there are the Zandé, or Azandé-I am not an authority on the spelling of Congo names, so leave it to my readers to choose their own phonetic rendering-the most powerful tribe in that part of Central Africa: as far above all others in intelligence and civilization as the primitive pigmies are below them. These, besides others of less importance, gave me plenty of opportunity for ethnological study at first hand; but the tribes among whom I spent my last three years in the district of the Upper Aruwimi were far less interesting. Nevertheless they had a number of customs and peculiarities that are worth recording; and I had this advantage-that I was able to make some comparison between them and the natives of the Upper Uelle, hundreds of miles away. On this subject I shall have occasion to mention one or two points which ethnologists with a wider range of knowledge than mine will find it worth their while to note. First of all, however, I will give some idea of the people themselves.

My nearest neighbours were the Basoko, whose country lay around the station of Basoko, which was my headquarters. It is the usual thing for the principal centre of a tribe to take its name from the tribe, just as it is usual for the villages to take their name from the chief-a most annoying feature of native geography, 
whereby places so frequently change their names that map-making for the use of instructing native guides is reduced to a waste of time. The Basoko, living on the north bank of the river, and inhabiting a long, narrow stretch of country, naturally devote themselves very little to the cultivation of the land, and go in almost exclusively for fishing. For the most part they fish at night, going out in the moonlight in their long canoes, two or three of them together. They are a very demonstrative people, and are apt to be a great nuisance if they are fishing at night near the station or in the neighbourhood of a village; for they dance in their frail canoes, yell with delight, and make the night hideous generally if they happen to have the good luck to make a pretty good haul; and this they do frequently, notwithstanding their primitive and restricted tackle. Their nets, though always very small, are fairly well made; but their hooks and lines would have made old John Stewart stare. They use a kind of Stewart tackle made of thorns deftly bound on to grass string, five or six thorns one above the other; these they bait and then spin with them. They use no reel, and if they hook a big fish their method is to let him tow the canoe about until he is played out, when they generally contrive to land him in the shallows. Often they land quite heavy fish in their canoes out in the stream; how they do it I cannot say. Their nets are mostly of the circular pattern, and quite small. I once saw a remarkable catch made with one of these small nets. I was coming up the river in a steamer, and we had tied up for the night. It was after dusk and a bright moon was shining.

Far away across the stream I could just discern some canoes flitting about in the shadows, seeming to be hard at work, but in silence. Presently arose that frantic, delighted yelling of native satisfaction, which is unmistakable in its intent wherever you may hear it. I was tired, but I wanted to know what the commotion was about, so I sent some of my men across in a canoe to see what was going on. In a few minutes they returned and told me the natives who were fishing had captured a big fish, and they proceeded to describe it to me with what I thought to be the assistance of their own imaginations. I suggested that the fishermen should bring their booty to show me, and presently they did so. The fish was really an enormous creature-a species of catfish, with feelers at its jaws and a ground-feeding mouth. 
The men had run a pole through its gills and were carrying it on their shoulders; and when they stood up with it the tail of it trailed on the ground. I asked to be shown the net they had caught it in, and they brought out a little thing of the épervier pattern, circular, with rings about eighteen inches in diameterand it must be remembered that they brought the fish from the bottom of the river. As I said before, how they do it I do not

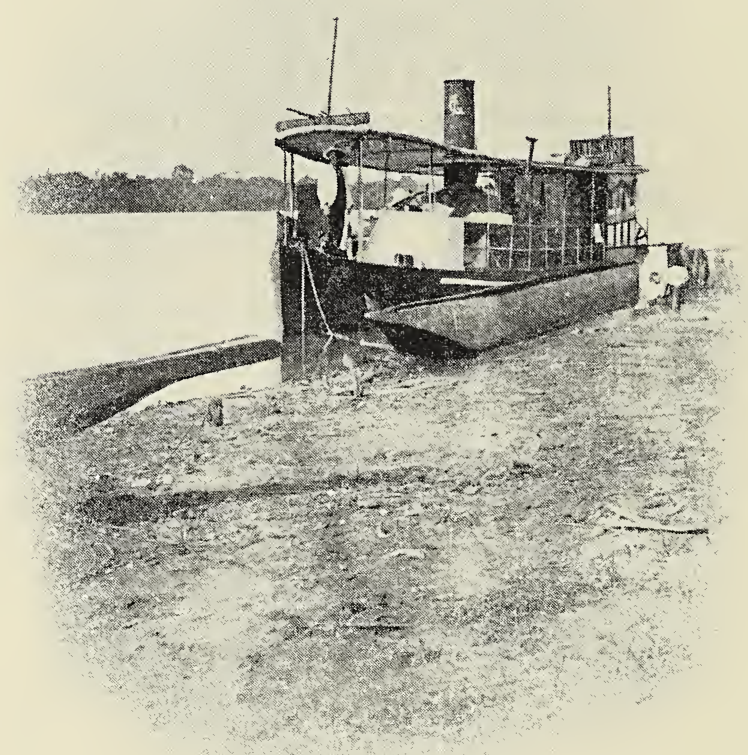

STEAMER OF THE LOMAMI COMPANY.

know. They are not a communicative people, and jealously guard their trade secrets; and had I attempted to find out they would simply have desisted from fishing. They seldom fish by day. I have seen them sometimes fishing with flares, but never spearing; this may be because they do not carry lances. They are not a fighting tribe. 
Great markets are held at all the points along the river-bank. There is a big market in one or other of the villages every day of the week, and the Basoko are very keen traders at them. For the most part it is the women who take the fish to the market, having first smoke-dried them. The markets are enormous concourses of people, natives of other tribes who cultivate and hunt coming in with their produce to barter and exchange for

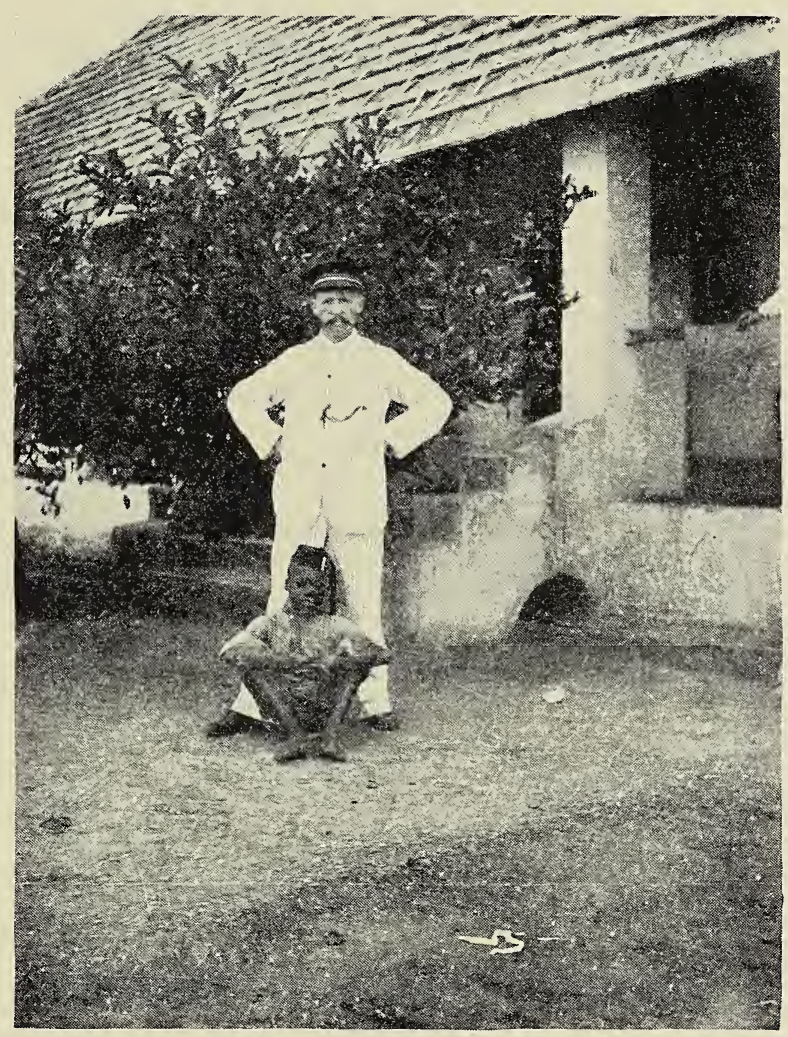

HOFFMAN AND BOY.

the dried fish of the Basoko. By common consent all weapons are always left at home on market days, and you never see such a thing as a spear or knife. The natives of the interior look upon fighting as a pastime to be kept quite distinct from the business of chaffering and bartering, and the consequence is that the markets are very orderly gatherings. Any disputes are settled with much noise and argument, but never by an appeal to 
arms. The natives, with their primitive but very sound sense of justice, would make it very bad for anyone who departed from this useful rule.

In the White Ant month the natives have a very busy time. The river is deserted, and men and women, boys and girls, go out to gather the white ant for food. I cannot say I admire their taste; but the white ant is not bad as food-merely very rich. In this month he is about an inch long; the natives gather him in his hundreds, pull off the wings, and roast him. The native boys have a shorter way with him. Sometimes at mess white ants flopped on to the table, attracted by the light. The boys who were waiting pounced on them, and without further ceremony popped them into their mouths.

The electric fish is very commonly found on the Congo, and the Basoko have a curious custom in regard to it. The men will not eat it; the women do. I tried to find out why, but the only reason I could get was, "the fish is only fit food for women; it is no food for men." I am convinced there is some reason, probably connected with superstition, underlying this; but I have never been able to fathom it.

There is not much iron about that part of the country. As the Basoko are domestically much farther advanced than most of their neighbours, their country forms a ready market for such tribes in the neighbourhood as possess iron ore. There is a good deal of the metal in the Upper Aruwimi, especially in the country south of the Nepoko River. This tribe is rather skilled at smelting. They build high conical furnaces, in which they manage to get up a good forced draught, and they puddle out the molten metal into lumps of about three to five feet long and about a foot thick. These they bring down the Aruwimi and barter them with the Basoko in exchange for the black palm-oil of the Palma elais. They are very fond of this oil, which they use to rub into their hair, working their tresses into a hard, filthy, caked mass, which among them is considered a great beauty. I think the Basoko have the best of the bargain, for there are some very skilful smiths among them. Their smithy outfit is primitive, but quite sufficient; their bellows are formed with a couple of goat-skins, their forge is a simple iron trough, and a pointed piece of iron placed in the ground is their anvil. Their work is all hammered, 
and is sometimes of very good quality, while the native mind sometimes runs to quaint and pleasing fancies in the matter of design.

Ordinarily the Basoko carry no spears or lances, preferring the quieter pursuits of the water. But they have one spear which is a very remarkable affair. It is about ten feet long, with a long thin blade and a straight wooden shaft of about the thickness of a forefinger. It is much too long for one man, and is thrown by two, standing one behind the other. I have seen it thrown for exhibition, when I wanted to see how they directed it; but I have never seen it in practical use. The natives told me they used it for killing buck, but I should say it was an awkward weapon to pull about in the bush, and gave the buck double chances of escape. It probably owes its origin to that curious native logic which sometimes takes the following syllogistic form:- "A spear will kill a buck; therefore a big spear will kill a big buck."

The Basoko are great athletes, and there is nothing they delight in so much as wrestling matches. Their meetings are full of fun. They are generally held on a Sunday, when the State natives have less to do; and the usual method is for one village to challenge another. The spectators squat down and form a wide ring in the open square in the centre of the village. Then one of the home team comes out into the middle of the ring and shouts his challenge. An opponent is selected to meet him who is suspected of being just about the same skill, for the native in this respect is a thorough sportsman, and prefers a good hardfought bout to a walk-over for his own side. The two grin pleasantly at one another, answering to the proceeding of shaking hands at home; then they work round for a grip, and the game begins. The style of wrestling is peculiar; each man wears a loin-cloth, and the idea which finds most favour is to get one hand through the cloth just above the hip, and the other hand on the opposite shoulder. While the men are swaying together for a fall, the women of the villages run round the ring at a measured pace and clap their hands, while some of the boys beat wooden drums, to the rhythm of which the women run. The throw is very simple; the man must be thrown squarely on to his back, and the bout is at an end. When one of the combatants is thrown, the women go into the ring and salute the victor, after 
which another pair comes out. Everything proceeds goodtemperedly, and I have never known a quarrel arise at a wrestling meeting. As at markets, all weapons are left at home.

As Commandant of the State forces in the Upper Uelle I had frequently come across native superstition in many forms; and in my book on the district I made a few notes on the more interesting of them. At that time, however, I was not in a position to give as facts a good many of my notes and observations of the extraordinary phenomena of native belief, because it was difficult to distinguish between the transient fears and those which had

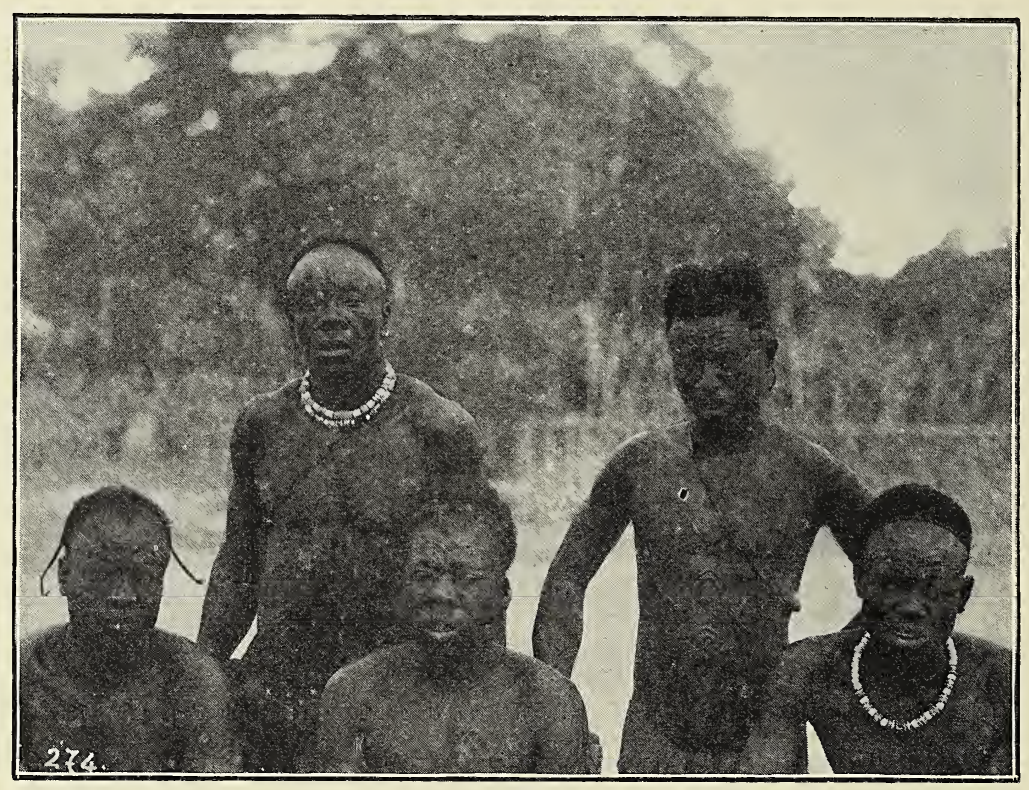

UPOTOS.

crystallised into custom. In the Basoko district I was more fortunate, and was moreover able to obtain confirmation of some observations I had made in the Uelle district, notwithstanding the fact that my new venue was many thousand miles from my former headquarters.

What the natives know as "Kilima" is the most extraordinary of their superstitions. Kilima is not exactly a divine being; nor is he the personification of evil, but partakes of the qualities of both, with some added. I thought at one time that Kilima was the 
native expression for pantheism, or rather for the theistic idea of nature's manifestations. I was led to this idea by the answers I got from natives when I asked them to explain Kilima. The rainbow was Kilima; the thunder was Kilima in a rage; the reflection in the water was equivalent to Kilima's seeing everything. Anything they were unable to explain was ascribed to Kilima; and as most unexplained things were natural phenomena, the idea of nature worship seemed a probable solution of the question. The theory, however, was quite disposed of when I learnt one day, in the course of an unofficial inquiry, that Kilima

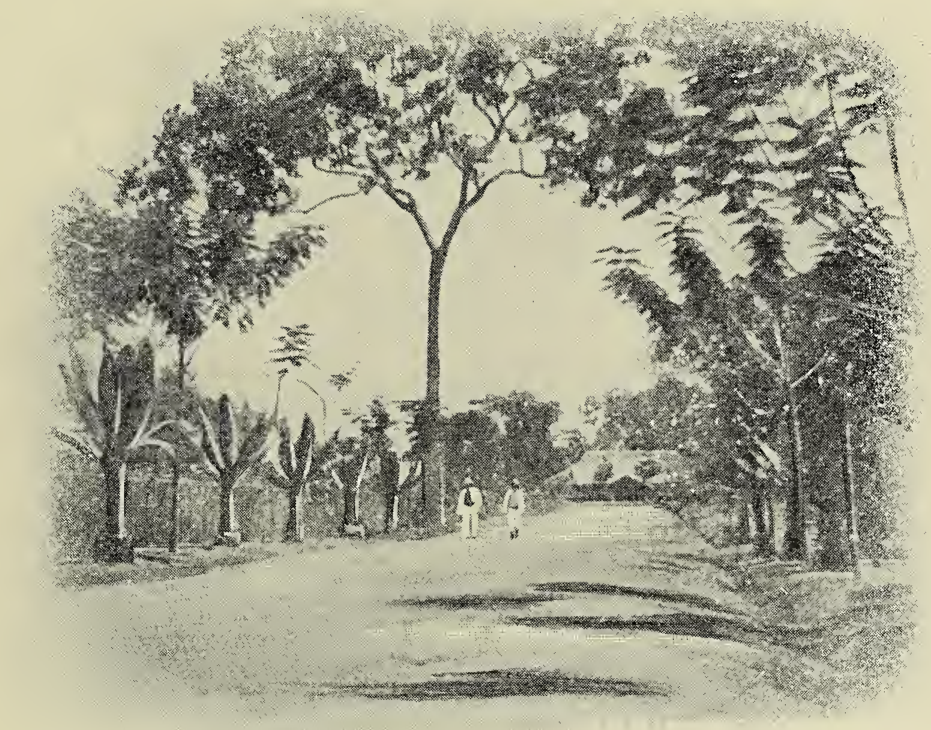

THE AVEnUE, Limbutu.

was "a large animal with a curved red back," and that he lived in the water.

When I left the Uelle and came to the forest of the Aruwimi I imagined that I should come to another set of faiths altogether. The believers in Kilima in the Uelle district were the tribe known as the Monbuttu (I was accustomed to the more phonetic Mangbettou, but scientists seem to prefer the other form), and their country is very many miles away from that of the Basoko; moreover, there is no communication between the two. But I had 
not been long in the Aruwimi district before I discovered the activity of Kilima. My discovery was made in the course of a judicial inquiry into the report of one of my men, which warned me that some of the Basoko near the station had decided to kill their local witch-doctor. The witch-doctor is always a nuisance; but he was as much entitled to my protection as the man whose property he was supposed to bewitch, so I had the whole lot arrested and brought before me, witch-doctor with them. The natives were fairly intelligent specimens, and I got very coherent replies from them. In brief, they told me that they believed the witch-doctor was in communication with Kilima, and was a friend of his. They asserted that the witch-doctor was known to pay visits to Kilima in the latter's home in the water, and they wanted to put an end to these meetings, as it was the aim of Kilima to work mischief in the village through the agency of the witch-doctor. I demanded evidence. "How do you know he is a friend of Kilima?" I asked. They looked meaningly at one another, and there was more in it; but not another word could I extract. So I dealt impartial justice by promising to punish the witch-doctor if he disturbed the peace of the village, and to visit severely on the tribe any further attempt to molest the witch-doctor. I heard no more of that particular matter, but I frequently afterwards encountered the workings of Kilima.

One case in particular which happened during my stay on the Uelle was uncanny and mysterious to an unpleasant degree. Four men were sent up the river in a boat to collect pebbles in the shallow water, about a mile above Nyangara. Their boat was a dug-out canoe, about three feet deep. The men, Monbuttus, were working in the water, which was quite shallow, and at no place could have been more than knee-deep; and the boat was moored about five feet from the bank. I was at Nyangara at the time, and was sitting under the verandah. Suddenly one of the four men appeared at the station. He was quaking and trembling with fear, breathless with running, and far too terrified to speak. We asked him what had happened; but he seemed quite unable to explain, so I questioned him as to the whereabouts of his companions. All he could say was that Kilima had taken them. Bit by bit we got a story out of him. While they were 
sitting in the canoe, he said, the boat was suddenly flung into the air from beneath, and they all fell out into the water. He himself had made a dash for the shore. The canoe had been sunk and the other men had disappeared. I asked him if he had seen the animal, but could get no coherent answer. It could not have been a hippopotamus; the water at the spot, which I inspected later, was far too shallow, and they would have seen any animal coming for at least fifty yards; besides, natives are observant of all signs of danger. Neither could it have been a crocodile, nor anything else I could think of, so I had to give up speculation. But the sequel was the most extraordinary part of the occurrence. Exactly twenty-four hours after the thing must have happened, the sentry on the river-bank saw a corpse float by. A boat was sent out to bring it in, and it was found to be the body of one of the four men. There was not a single mark of violence about the body, and absolutely nothing to show how the man had come by his death. Exactly twenty-four hours later the second came by and was brought ashore, and at the same hour on the following day came the third, and in neither case was there anything to show how death had occurred. It was altogether a most uncanny business.

Just before I came away, two cases of alleged Kilima occurred at Basoko, quite close to my house. I came across them in much the same way as I had discovered the previous manifestation of the mystery-through the threat of some of the natives to kill a witch-doctor. The men explained to me that the witchdoctor, whenever he had a grudge against a man, used to seek out Kilima and get this strange being to take away one of the man's wives when she went out in a canoe. Just below my house shortly afterwards was found the body of a woman belonging to one of the men who had wanted to kill the witchdoctor. She was quite dead, and lay on her face in the shallow water, with absolutely no sign of a struggle or other sign to indicate how she died. But she was seen to start out in broad daylight, and it was in broad daylight and in the open river that she was found thus, dead! Precisely the same thing happened under precisely similar circumstances to a wife of another of the complainants, which was mysterious, to say the least of it; for these women swim like fishes, and in any case could not 
have been drowned. The natives came once more and complained about the witch-doctor, and I was obliged to inquire into the business, though I did so with considerable reluctance; for there could be no question of the witch-doctor's having had a personal hand in their death, and I did not care to go to work on a charge that seemed mysterious enough, but absolutely based on a groundwork of native superstition. However, I had the witchdoctor brought before me, and he came jauntily enough, as a man conscious of power. He was wise enough to deny roundly that he had any hand in the death of the two women, but stated

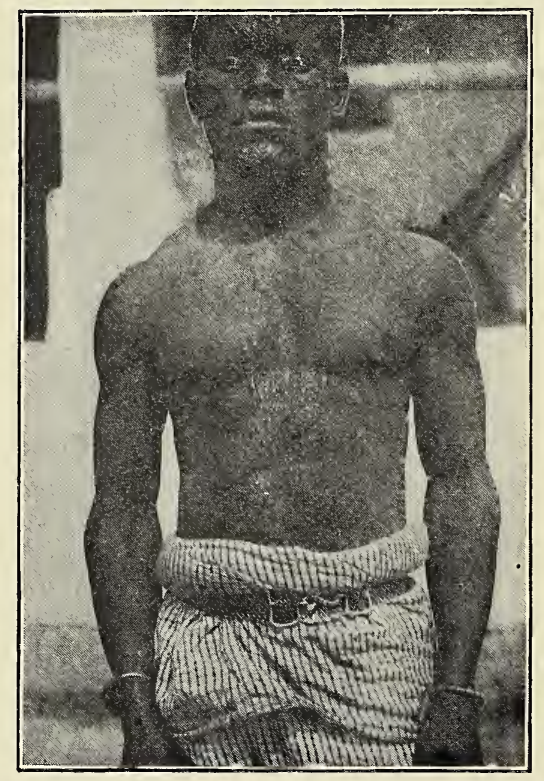

TOPOKÉ CHIEF.

that he was a friend of Kilima, and that Kilima had killed them as a punishment to the two men. I tried to get some information about Kilima. "It was a big beast," he said vaguely, indicating a creature of enormous dimensions; "and it lived under the water, where it built itself a house of sticks and dead leaves." He told me that Kilima lived near the station, and he seemed to think at the same time that it was but the embodiment of some great force, for he told me that Kilima was everywhere. Then he said he knew where Kilima's house was, 
and often went there; and from the way he told me I know he had some place in his mind. But I could not get him to take me to the place or describe where it was. When I asked him what Kilima did to the people whom he killed, he said, without a moment's hesitation, that Kilima sucked their brains out through their nostrils. All I could do to the man was to warn him against disturbing other people, and I promised him severe punishment if I had another complaint about him.

I found the oracle of poison among the Basoko, as I had found it among the Monbuttu, and they appeared to have the

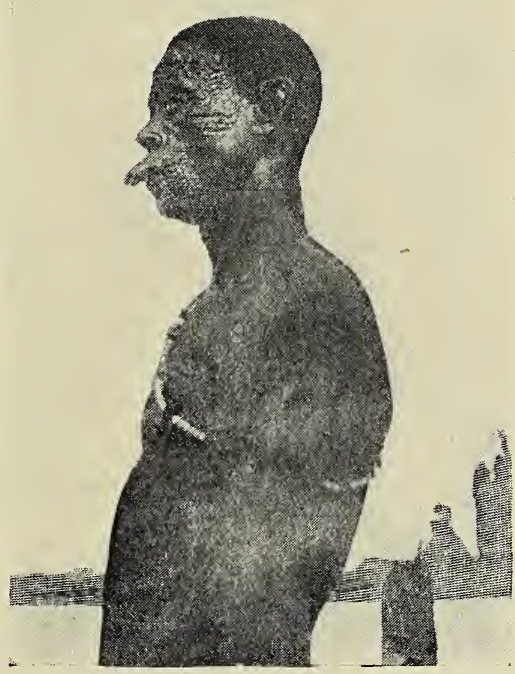

TOPOKÉ.

same faith in it. The mixture is made from the plant Strychnos scaja, and is given to the accused man in a cup. The strength of the poison of course depends on the witch-doctor, who is bribed, as a rule, by the relations of the accused; and he usually tempers the poison in proportion to the bribe. If the poison is weak enough it acts merely as an emetic, and the accused is considered not guilty; if strong, he dies. The natives have blind faith in the test, however; often when a man has protested his innocence to me, he has said, "If you do not believe me, give me benge; benge cannot lie." 
A somewhat similar custom is observed among the Basoko to test the faithfulness of a woman. The bark of the acacia tree is pounded up and a more or less poisonous mixture is made; and this is put into the eye of the suspect. It does not destroy the sight, but merely tends to inflame the eye. If it fails to do so, she is innocent; but if her eye becomes red and swollen and discoloured, she is considered guilty. And this is, in my experience, always the verdict.

On the other side of the river dwell the Gombé, who are a much less civilized folk than the Basoko. They are a very savage lot, constantly fighting, and behaving cruelly to their prisoners. I fought them on two or three occasions, and found them brave enough; but their methods of fighting were peculiar, and had to be learnt by bitter and unpleasant experience. They do not attack, but always retreat and draw their enemy on-reminding one very much of the hen lapwing, who pretends she is lame in order to draw attention from her nest on the ground. Only, with these people, it is the other way about; they want to draw the attacking party into their nest. On my first expedition against them we had crossed over from Basoko with two white men and about fifty soldiers. We proceeded along a bush track towards the village, and had not gone far when some of the Gombé were sighted. They were not acting in the least like decoys, but rather like scouts, so we made haste to follow them up. This movement was just what they wanted; it took us into a hornet's nest of Gombé, and in a moment they were raining down spears upon us from the high trees. They had climbed along the branches, and had us at their mercy. Their spears are only wooden, for they have no iron; but a hardwood spear, with the sharp wooden point still further hardened, is a deadly weapon, as we found to our cost. We lost one white man, one man prisoner, and about ten soldiers killed, besides a number of wounded. The prisoner had a bad time among them. I found out afterwards that they took him off to their village and there debated what they should do with him, he, poor fellow, having to be witness of their deliberations in a dialect which he did not understand. Finally (for I found out afterwards what had happened) one of the more cruel of the chiefs carried the day; they tied the unfortunate man's hands and feet, slung him up face 
downwards in a tree, and marched round him, each taking a cut at him, or a lance-thrust, as he passed-being careful enough not to kill him. When at last the poor fellow died in agony they cut him down and held a cannibal feast.

Meanwhile we, who had been driven back, got further reinforcements, and, armed with a better knowledge of Gombé methods, came on again. This time there was no mistake. We dropped the Gombe from their branches with Albini bullets before we came within range of the wooden spears, except in a few cases where they were too well concealed. In the rout that followed I came up with the particular chief who had instituted the cruel procedure I have just described, whose description from a native spy had enabled me to recognise him. I noticed that he wore a grimy black thumb round his neck as a charm. I had been told that; so there was no mistake, and, as he continued to show fight, I shot him. But even if we had taken him prisoner he would have had to be shot. We could not afford people of his propensities in the neighbourhood of a peaceful station.

This was not the only trick the Gombe had in their system of bush tactics. In fighting against other natives it was a favourite practice of theirs to secrete all their goats and fowls at a spot some distance from the place they desired to fight in. They would take a goat, or perhaps two, and would bury it in the ground, leaving only its lips and nose sticking out. Meanwhile they would hide close by in the high trees, ready with their wooden lances and throwing-spears. Their opponents who did not happen to know the pleasant little ruse would hear the cries of the uncomfortable goat, and would of course follow up the sound, for in war the native always makes for the spot where he thinks there is something to be got. The opposing force rushes up and sees no goat, but only hears it; and when sufficient of them have joined in the search, the Gombé, who have lain perfectly still, let fly at their foes, who are thus ambushed.

In after times I went a good deal among the Gombé on less warlike missions. I found them always savagely and brutally inclined, and certainly not of prepossessing appearance; in fact, the character of their tribe was written in their low-browed, sullen-looking faces. But in many ways they were interesting 
enough, though reticent. They had in their possession a considerable quantity of copper, which their smiths used to work very skilfully; but I could never make out where they got it from, though I often saw the raw ore placed ready for smelting. I think it came from some place south of the Congo. They have no iron, however, which must be a great drawback to them. They are not a trading tribe, and certainly would not go out of their way to trade in any commodity which was not brought into their country, as I suspect the copper is. The natives who gather the iron ore and who do all the smelting in these parts have no dealings whatever with the Gombé, from whom they are separated by a dangerous distance-which in Africa means that there are tribes

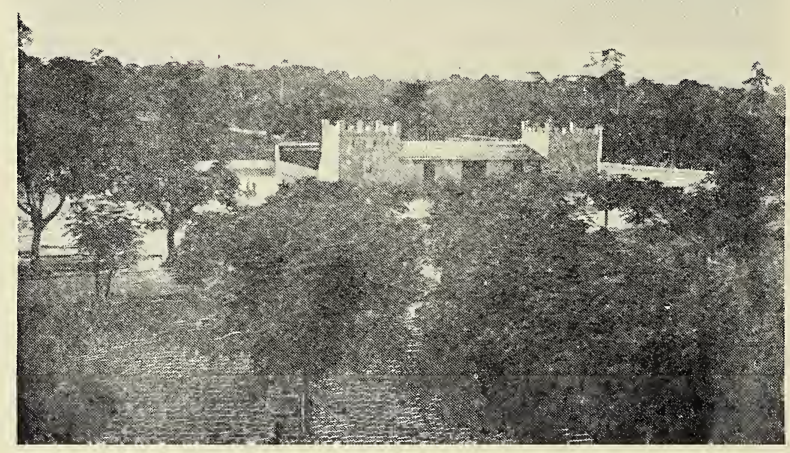

OVERLOOKING BASOKO.

between them who would make a meal of them if they tried to pass over the intervening territority. About these smelters of iron I shall have something to say further on. To return to the Gombé: one of the most curious customs of this tribe (a custom one meets with frequently) is that performed by them on the occasion of a death in the tribe for other reasons than fighting. They lay the departed out in state, and hold an enormous "wake" during the night, in which the whole village takes part. On the next day they cut off the first joint of each finger and toe, and these are distributed among his nearest relations, and are intended as charms. Then they dig a grave, about four or five feet deep, circular, and just wide enough to let down the body, which is 
placed in a sitting position, with legs and hands crossed. What the object of this was I could never find out. Afterwards they filled in the grave and built a little thatched roof over it on corner posts about a foot high. A dance completes the proceedings, and they then disperse to their ordinary avocations. The thatch is never repaired, and when it has disappeared there is an end to the memory of the deceased.

They are absolute savages in almost every respect, as the following illustration will show. One man was brought into my station-the tribe was within my jurisdiction-for the murder of his wife. When I came to go into the question I found that the man, who was a brother of the chief, and therefore an important

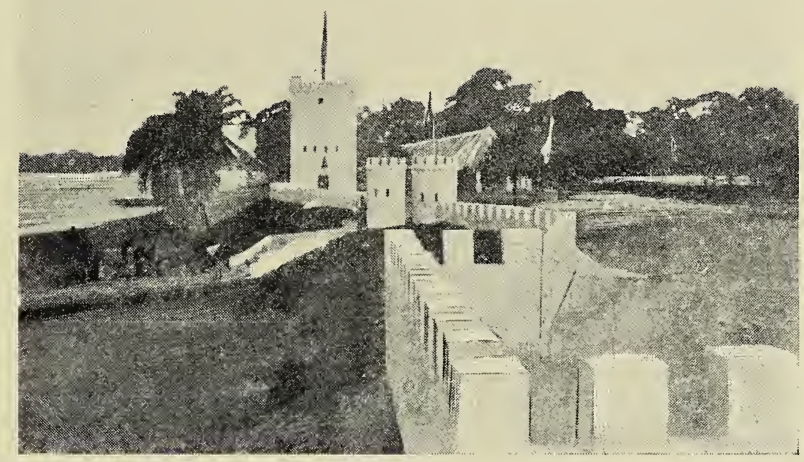

BASOKO.

person in his way, had suspected his wife of adultery; and he explained that he had cut her open to see if that was so or not. He explained it in all seriousness, and it appeared that it was quite the usual way of settling doubts of this kind among the Gombé. To one given to look into the native mind with a certain amount of subjective observation, it made the administration of justice rather difficult of accomplishment.

Behind Basoko and north of the Congo is the territory of the Mobongo. These people have not properly been explored. Only very rarely have white men been among them, and they are not anxious to have any dealings with the State officials if it can be avoided. The Belgians, for their part, make no attempt to open 
up intercourse with the tribes who are not directly on the waterways, a feature of their colonisation that in part accounts for the deplorable state of the Congo as an administrative colony. The Mobongo see in the Belgians a treacherous enemy, well armed, and rapacious for ivory and rubber; therefore an enemy to be resisted to the utmost where they cannot be avoided altogetherand this is a common view, to be found throughout the country as soon as you get off the trade tracks. I found the Mobongo quite unapproachable in the ordinary sense. On rare occasions I went among them, however, and with some difficulty had peaceable dealings with them. They differ from the other tribes round them in this respect, that they use the spoon; they make themselves little ivory spoons, very delicately carved and often gracefully designed, which they use for eating their meat. This is, I think, the only example of this domestic utensil in these parts. It does not, so far as I was able to make out, betoken them to be at all further advanced socially than the Gombe, who eat their food with their fingers; and I was convinced, on the occasion of my encounter with them, of the fallacy of reasoning that implements imply social distinction. Why they use these little spoons I cannot say. It is certainly not for any nice reason, and is probably merely a custom that grew out of accident. In their own untutored way, however, they are very skilled in the working of ivory. I found some very pretty ivory bangles among them, a curiosity not often found in the Congo, as the making of them cuts too much to waste. Perhaps they are more profligate of the ivory they have; though, as near as I could make out, they do not appear to use ivory in any other way but for making spoons and bangles.

They are cultivators of the soil, and, among other things, they grow the yam-not the sweet potato, but the real yam. In this respect they are peculiar.

On the occasion of one visit I paid them, I spent a night at one of their villages as a guest of the chief, who, having to entertain a white man-at least, he thought he had to-did the thing handsomely, and wound up the evening with a war dance for my benefit. In this way I obtained a good idea of the Mobongo methods of fighting, for the dance was very dramatically executed. The natives who took part in it went through the whole story of a fight from beginning to end, acting so well that it 
was easy to follow every stage of it. The dance showed, first of all, the news of attack; then the scouting; then the evident approach of the enemy, until the two were at close quarters. Then the Mobongo lay down on their faces, two and two behind one another. The noise ceased, and they came crawling along the ground like a long, half-human, silently intelligent serpent. Then, when the imaginary enemy was clearly ambushed, there was the sound of a shield tapped with a spear, and immediately the whole hundred were on their feet, wheeled, and charged like a rush of wind. I suppose it was inhospitable of me, but I made a mental note of the tactics in case the knowledge might some day come in useful. On the Congo your friend of to-day is your open enemy to-morrow, and it is just as well if you know his methods.

I had not been long in my district before I made the acquaintance of the Topoke and Lukeli tribes. They lay along the river Lomami, in the long strip of country which formed the southern arm of my district. The Lukeli were of less importance, reckoning by the degree of trouble they gave; for theirs was essentially a river life, and in consequence they were disposed to be peaceful. They spend their whole time in their canoes, engaged in fishing, and are in their trade perhaps even cleverer than the Basoko. They rarely came ashore, but drifted about in their canoes on the stream ; they smoke their fish on board their boats, and dispose of it at the weekly markets with much chattering and bargaining. Consequently I had little occasion to observe them; for although they have villages they are by no means attached to them, and desert on the slightest provocation homes which they never inhabit. This drifting existence tends to make them extremely nomadic, and I should not be surprised if, before long, they are not altogether foreign to the Aruwimi district. Like the rest, they are cannibals when they get the opportunity.

The Topoké are men of another stamp, and essentially a shore tribe. Their villages are scattered up and down the banks of the Lomami, and they come a good deal into contact with the white men. I fought them often, and found them very plucky foes. Their method of fighting is peculiar, and my first experience of it was very unpleasant. I was marching through a corner of their country on my way to call a village to account for some mis- 
demeanour. With me were some twenty soldiers, armed with Albini rifles. Our route lay through a swampy country, covered thinly with rank undergrowth and stunted forest, which afforded very good cover for an enemy, but which made pursuit almost impossible. The track, like all bush paths, was narrow, and admitted only of single-file marching; off the track the ground was a morass. Probably the Topoké of that locality had guilty consciences; anyhow, they thought we had come to visit them, and they followed the bush rule of "get your blow in first." The file marched on, when suddenly the last man was bowled over by a throwing-spear,

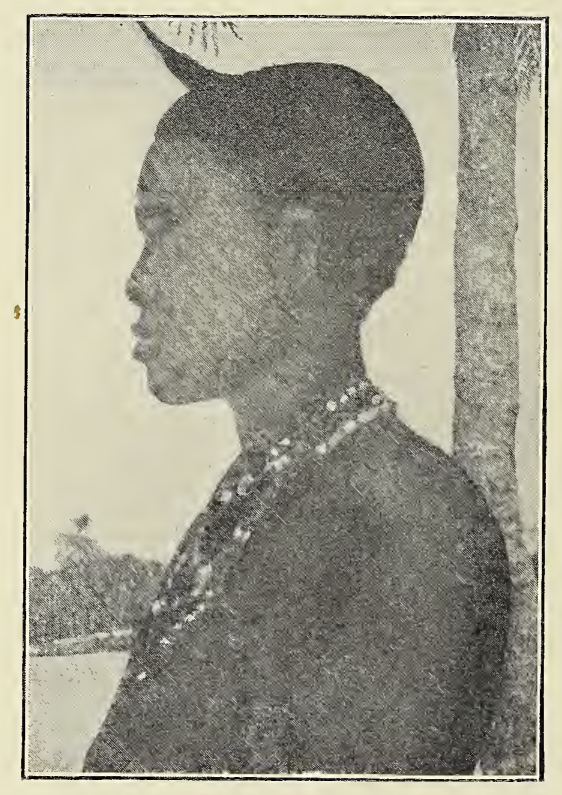

BARUMBU NATIVE, BASOKO.

which hit him in the back. Not a soul was visible, and no likely hiding-place at hand near enough to cover a spearman at the range at which this spear must have been thrown. So we tied the wounded man up as best we could, and proceeded. Not far off another man, also the last of the file, narrowly escaped a spear which passed just over his head. I halted the men and sent a random volley across the morass, apparently with no effect whatever. Then I saw a tussock of rank grass move, and in a moment we had the secret of the Topoké method of fighting. The man stood in a deep morass with merely his head out of the ground, 
behind just sufficient cover to hide him. Then, when we had passed, he had raised himself to free his arms and shoulders, had flung his spear at the last man in the column, and had bobbed down again.

For some time before I arrived on the scene of the Lomami, a Topoké witch-doctor, named Lifeta, a big chief in his way, had been amusing himself by killing State soldiers. His village lay some way up a side stream, called the Lukombi, in the track employed by messengers proceeding between two stations, and letter-carriers were his special mark. When these were not to

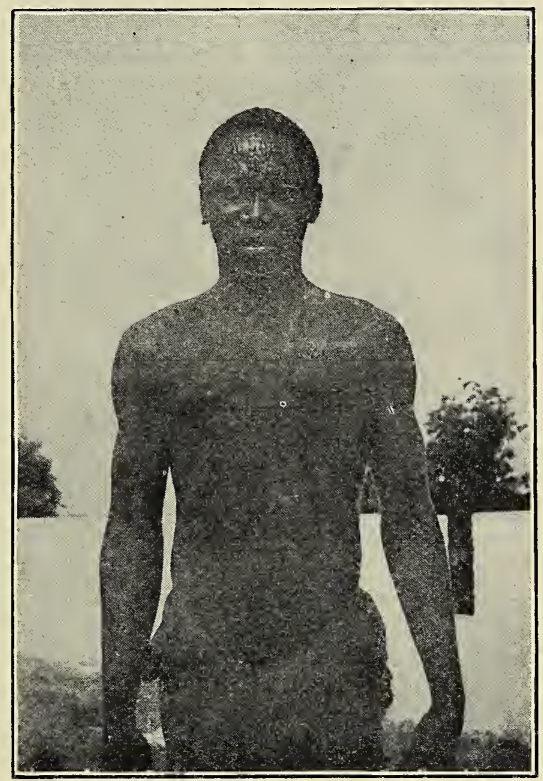

SON OF CHIEF MÖIMBA, BASOKO.

be had, he used to raid other villages and carry off the women, as well as one or two men, for his cannibal orgies, for he lived practically on human flesh. His plan was to ambush any wanderer or messenger who came his way, and, having killed and eaten him, he would very cleverly lay out the bones to look like the skeleton of a man who might have died in the bush. For four years he kept the district in a state of terror; De Keyser, my predecessor, utterly failed to cope with him. The old man had an extraordinary hold over his people, who believed in him implicitly. Once in the past he had been wounded; a 
bullet had gone clean through him. But he recovered, and out of this accident he built up a legend that he was invulnerable. This, of course, increased his witch-doctoring influence to an enormous extent. When I came to the district he was still at his old games, and I determined to put a stop to them. So I sent out some twenty Mobangi soldiers with a sergeant, armed with Albini rifles, and put up a reward for his capture; the Lomami Company, in whose territory he lived, also offered a reward, and the Mobangi, who are among the best soldiers in the State, went out determined to win it. After about a week's march they came to the spot where he had been located. His village was somewhere in the bush, but we were unable to find it, and the people in the neighbourhood were afraid to give him away. At last the sergeant pursuaded two natives of the village to show him where the village lay hidden away in the bush. The natives came to within a quarter of a mile of the village, and, having indicated where it was, they bolted off, for they did not believe for a moment that twenty soldiers could rush this formidable village, and they were anxious to have no public connection with the attempt. The arrival of the soldiers soon, of course, became known to Lifeta, who came out of his hut and advanced towards them. He was followed by all his people who carried weapons; but he himself was unarmed. On seeing the soldiers he called out: "I am glad you have come to see us. We want some meat." He had so worked upon his villagers that they firmly believed no bullet could touch him, and I think he believed it himself. The soldiers made no reply, but only laughed and stood still. They waited till the whole crowd, chief included, were only twenty yards off; then they fired at the chief. He was knocked over, but got up again, and it took three volleys to kill him. Immediately the people saw their chief was killed they fled with one accord. The Mobangi brought Lifeta's head into camp, and received their reward. Lifeta's skull I took charge of, and it now rests in the Anthropological Society's Museum at St. George's Square. The net result of the expedition was that Lifeta's people gave up their guns, some fifty in number, and settled down to a peaceful existence, and during my term of office were a model of peaceful propriety. 


\section{CHAPTER XVI.}

METHODS OF IVARFARE.

DURING six years passed in the Congo I have had to encounter at various periods many different unfriendly tribes. It is very rarely that any two tribes use the same methods of warfare. The Azandé, one of the most warlike tribes of Central Africa, invariably attack the head and centre and the rear of a column on the march at the same moment, charging in columns from six to eight deep, thus occupying the head of the column and the rear, and cutting the column in half in the centre. These tactics are almost invariably carried out with success, owing to the difficulty of marching through the bush in any other formation than that of Indian file and the ability of these native warriors to charge through what apparently appears to be the thick bush.

The Topoké, another warlike and cannibal tribe situated in the angle between the Congo and the Lomami river, pursue altogether different tactics. Their territory is marshy and swampy to a degree, and out of this natural circumstance they have developed a curious system of defence. One of their methods, and a very common one, is to stand up to their necks in the mud in a swamp, hiding their heads behind some tuft or bush so that it is impossible to see them. They will then wait until the head of an attacking column appears, the men naturally being obliged to hold their rifles above their heads and at the mercy of the Topoke spear. The Topoké is able through long habit to move through these swamps so quickly that it is impossible for the attacking column to do anything. Where the ground is not marshy and the bush is thick, they will secrete themselves in pairs close to the path so carefully hidden that it is impossible to see them. They will let half the column pass by, when one of these men, who is armed with 
a shot-gun crammed full of slugs, will suddenly fire on the man who happens to be passing almost in touch with him. His companion, who is armed with a spear only, in case the bearer of the gun is wounded or killed, is always in attendance, enabling him to at least save the gun from being taken.

Amongst the Mombassa the methods are very different. The bush being very thick, they leave their villages and disappear in the forest. The march of a column is invariably attended by the tapping of a small wooden drum, so that the natives hidden in the forest know the position of their enemies. At various places

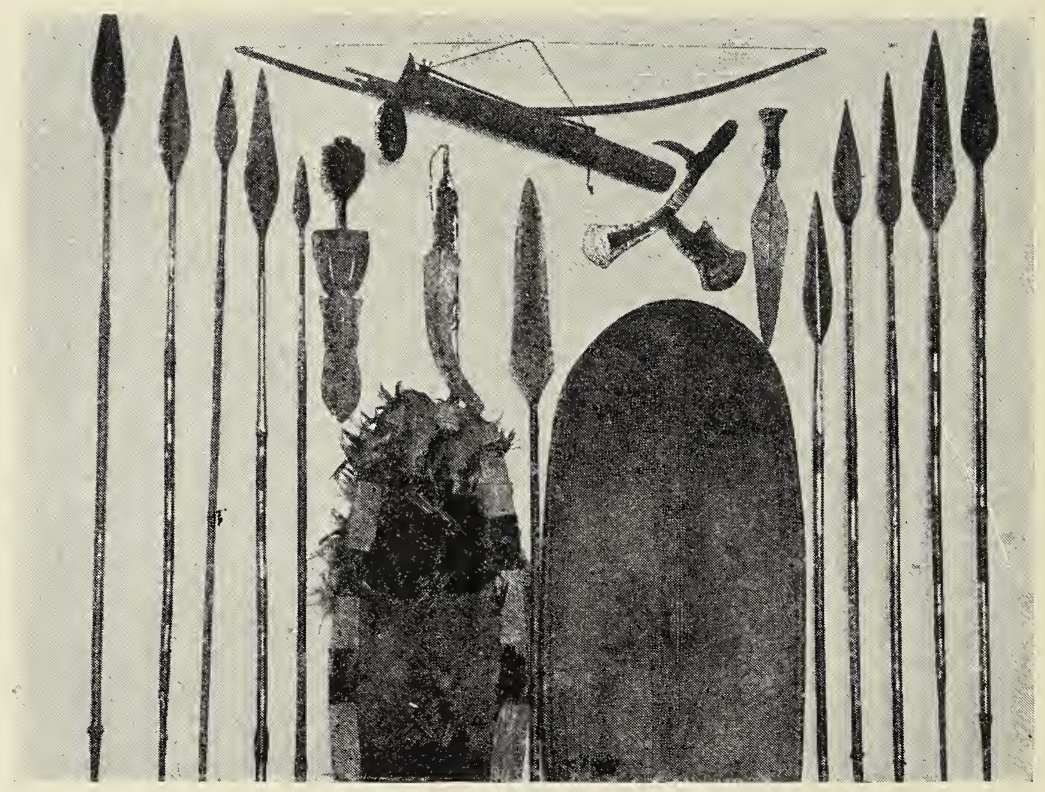

NATIVE WEAPONS.

the Mombassa bury, in a pit specially made for the purpose, a goat, leaving nothing exposed above the surface but the head. The goat, naturally objecting to this premature interment, protests loudly, and the native soldier, whose god is his belly, will, it is a hundred to one, quit the path to find the goat. In the meanwhile the natives are carefully hidden in a half-circle surrounding the buried goat. The native soldiers immediately place their rifles on the ground, and the whole crowd commence to dig up the goat, when they are uncomfortably surprised by a shower of poisoned 
arrows, followed by the charge of a yelling and shrieking mob armed with big-headed spears. This has happened time after time, in spite of the fact that the soldiers are perfectly well aware of this stratagem, though they almost invariably allow themselves to be caught.

Further south of the Mombassa, on the banks of the Lopori River, live a tribe who approach closely to the forefathers of the

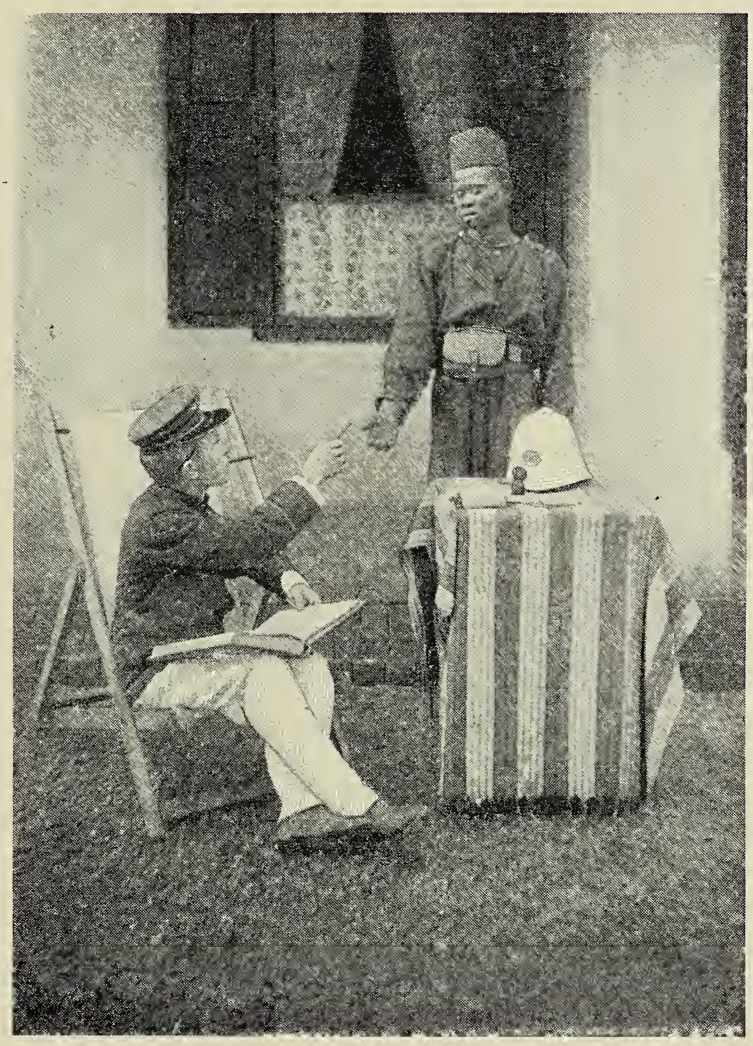

BELGIAN OFFICER AND NATIVE CORPORAL.

human race. On the approach of danger the women and children fly to the bush, together with the old men, whilst the fighting men advance against the enemy. Their methods are extremely curious. They are apt climbers, and every tree whose branches overhang the path is full o? these primitive warriors, armed with wooden lances-there being no iron in this country-and, as the attacking force passes underneath these trees, the lances are hurled 
into its midst from above. The first time I encountered these curious warriors we were very much puzzled to know where the lances came from. They also use small slivers of hardwood, pointed at each end, about six inches in length, one tip of which is poisoned. These are buried in the path leading to the village, with the poisoned tip just showing, in a slanting position, with the points just showing above the earth. To the native, who invariably goes barefooted, this hidden danger is a source of much trouble, the wood being so hard that it will easily penetrate an inch into the foot of the man walking over it.

Like all other savages, the Central African has developed a fine taste for torturing others, especially the white man when he can catch him. Many unfortunates who have fallen into their hands have had to pay the penalty for the cruelties practised by their own countrymen on the natives. One Belgian, who had not the pluck to keep a cartridge for himself, tamely allowed himself to be taken prisoner, was carefully taken to the village of his captors, and the following day was beaten to death by the women and girls, armed with clubs. This was practically a merciful death, for others have had to undergo far greater agonies. Three Belgians, who were captured by the natives in the Mongalla, were stripped and made to march in the heat of the day through the bush. One, the chief of the expedition, was obliged to carry the native chief on his shoulders, and during three days he was obliged to perform the most menial and degrading offices for his black master. After three days, these men were killed by the slow process of amputating the different members. Another white man who fell into the hands of the natives was taken to the village bound, and his fate hung in the balance for some time owing to the dispute between the young warriors and the elder. The older members of the tribe counselled against killing the white man, knowing the inevitable result. But the hot-blooded young men insisted on the murder of the prisoner. During the whole of this time the prisoner was lying within a few feet of his captors who were discussing his fate. Eventually the young warriors gained the day, the victim was stripped of all his clothes, and, his ankles and his wrists being tied together behind so that the front of the body formed a half-circle, a rope was attached to them and passed over the bough of a tree. The body was drawn up so that he was 
hanging by his ankles and his wrists. A war dance then commenced, and as each native passed underneath the suspended victim he showed his dexterity in the use of the knife by cutting the abdomen without inflicting a mortal wound. This continued until death ensued. When the body was taken down, the forearms were cut off and despatched to the different native markets, to prove to the whole of the surrounding district that one hated white man had been taken and killed. This was a very common practice amongst all native tribes of sending a portion of the body to be exposed at the native markets, to show the dissatisfaction of the tribe with the Europeans. Other white men have been taken alive, but each of these managed to procure a speedy death by pretending to draw a revolver from his pocket.

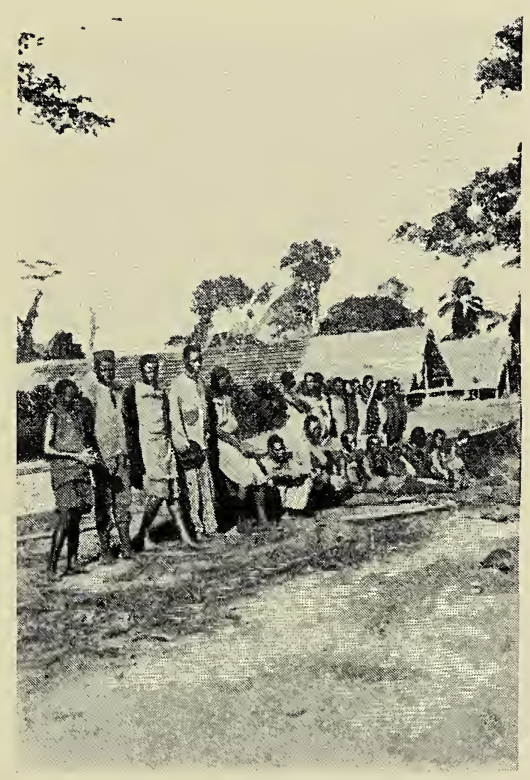




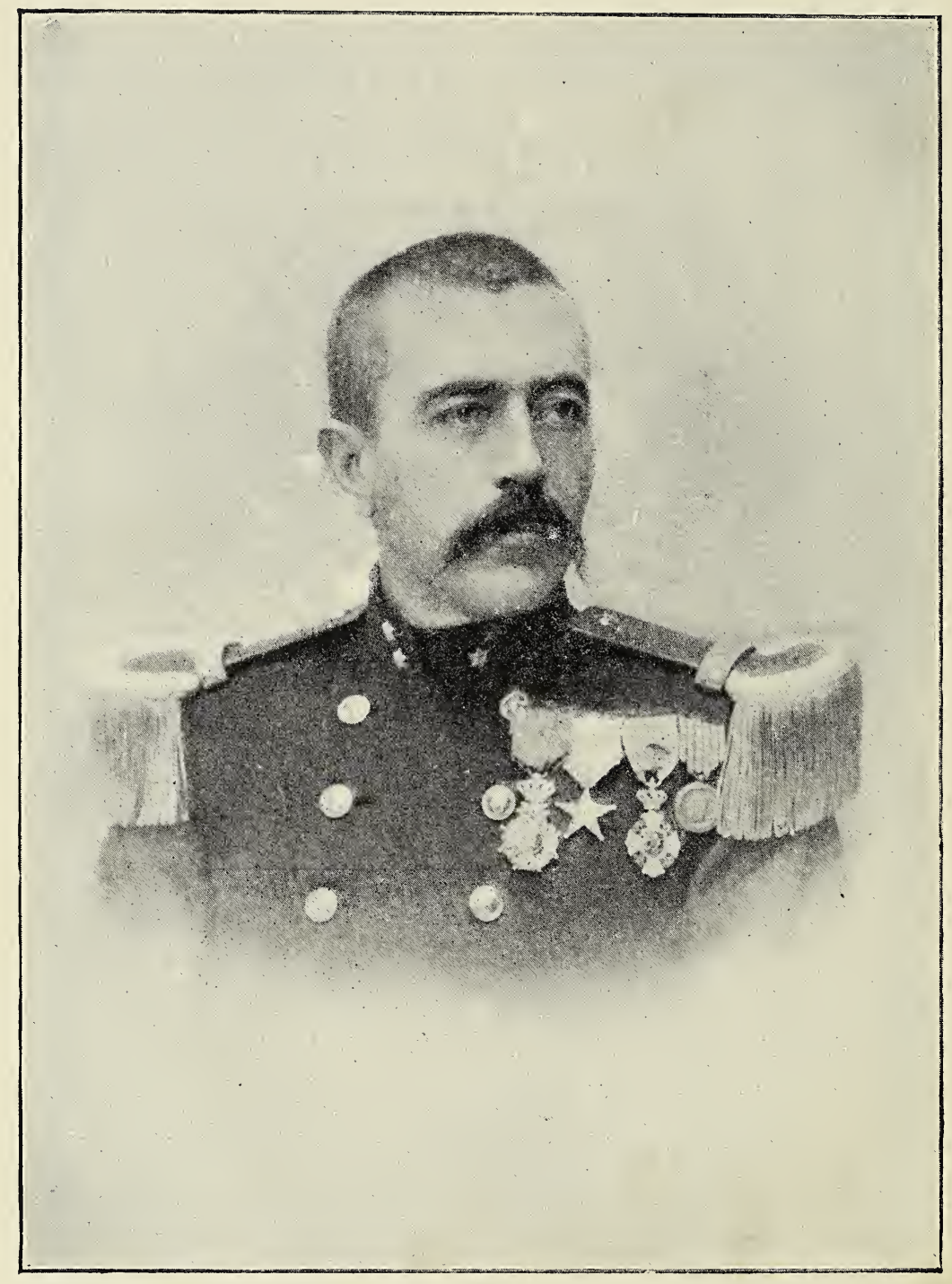

MAJOR LOTHAIRE. 


\section{CHAPTER XVII.}

\section{THE STATE AS SLAVE-RAIDER.}

An Expedition against the Batatela Mutineers-The "Münchausen of the Congo"The Fate of Lindsey Burke-The Balubas Enslaved-Ilanga's NarrativeGhastly Burdens-Murders on the March-The Slave System upheld by the State.

DURING the early part of 1897 , the Batatela soldiers-who had in 1895 mutinied at Luluabourg, and, after giving the Government much trouble, had wandered into regions unknown-suddenly reappeared along the Lomami River, and began a movement northward in the direction of Nyangwe, which place they had, no doubt, hopes of surprising. In order to meet this advance of the mutineers, the Governor-General, who was then at Kassongo, some two days' canoe voyage up river from Nyangwe, organised an expedition consisting of about 700 soldiers and eight or ten whites. This force was under the command of Commandant Michaux, a lieutenant of the Belgian army, who has achieved more fame as the "Münchausen of the Congo" than for his military ability or courage. A short sketch of him may, perhaps, be interesting as a type of "officer" frequently encountered in Central Africa.

The commandant always travelled with his harem, composed of forty-seven negresses, more or less, and surrounded by a body-guard of a score or so of young negroes, whom he called his macaques (baboons). He also was accompanied by a pet goat, some dogs, and other animals, and at night the whole herd, with the exception of the macaques, were crowded into a small tent, with himself in the midst of this odoriferous mass. He was a typical Belgian peasant, ugly to look upon, of medium height and great breadth of shoulder. He never opened his mouth without 
positively roaring, and never spoke many seconds without uttering a falsehood. His descriptions of sixty imaginary "combats," from which he invariably came out victorious, with only a few men against overwhelming odds, were really amusing. It is estimated that the number slain by himself and his men would have left scarcely a soul in all the Upper Congo. When under the influence of Congo-distilled "schnick" he would recount his adventures in a voice that was like the continuous roaring of many lions, and his huge paws would send our few and precious glasses jingling so violently against one another as to excite serious fears for their continued integrity. The gallant commandant, however, had no real craving for the gory fray, although his appetite for stimulants and food was usually very pronounced.

At the head-or rather in the centre-of his column he marched to meet the advancing Batatelas at such a pace that it was many days before he came in touch with them. When, finally, he encountered the enemy, he was all but routed; for had it not been for the care of an experienced Swedish officer he would certainly have had his column put to flight in a night attack which the rebels, under their leader Yambayamba, made upon the camp at Kapua. As it was, the Batatelas, in spite of their advance being discovered by the sentries posted by the Swedish officer, penetrated into the camp and carried off some of the baggage of the whites. No doubt they had hoped to secure the reserve ammunition, which they knew must be with the column.

This skirmish, which the brave commandant announced as a "victoire glorieuse," in which a small number of the enemy were slain, was not taken advantage of. The mutineers drew off, and, instead of sending a strong detachment at once in pursuit, the commandant allowed his column to leisurely march behind them. Scouting parties were sent out, and only once did they again come in touch with the enemy. It was on this occasion that my friend and countryman, Lindsey Burke, of Washington, when in charge of a reconnoitring party, was surprised and killed. It appeared that his men, having marched for some hours through long grass under the burning sun, were suffering greatly from thirst, when Burke pushed on rapidly with a few followers in search of water. The advance party had just issued from a belt of wood when it was fired upon by a band of the enemy concealed at short range. 
- The remainder of the men, on hearing the firing, at once dropped their rifles, and fled to the place where the commandant was already encamped. Of course, much blame was cast upon Burke, who, after all, had only acted under orders. Though perhaps at fault in not being more guarded, he at least died at the head of his men. Fear was unknown to him, although only a civilian, and he was ever to the front when danger menaced. Moreover, having been through half-a-dozen South American revolutions, he had probably more military experience than any of the officers of

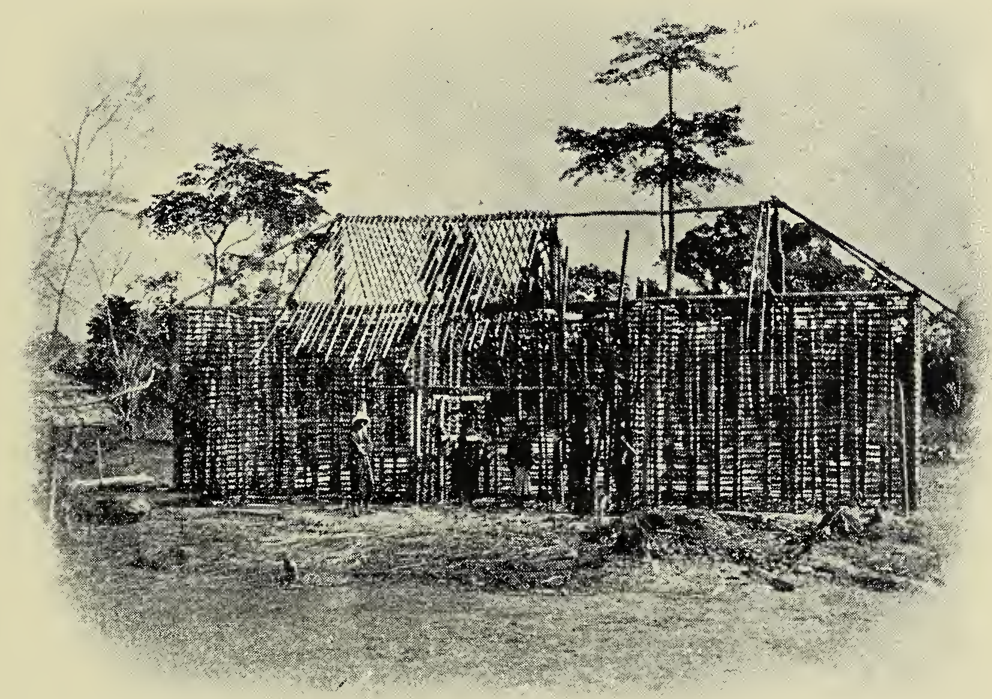

HOUSE-BUILDING, YAMBUYA.

Michaux's expedition. His headless and limbless trunk was found beside the trail, and buried in the long grass of the Urua.

After much fruitless and leisurely marching, the column returned to Nyangwe. About this time large numbers of Baluba slaves commenced to arrive at my post, frequently 300 in a batch. These people had been captured by the commandant, and carried off to work as slaves in the stations and on the plantations of the State. Many died of hunger and exposure, and quite a number, too sick to proceed, remained at the post. Those whom I succeeded in curing continued at Lokandu during the rest of my 
stay, and were employed on the plantations and other work. By treating them kindly I gained their confidence, and on moonlight nights they would sing for me their native songs, and dance the Baluba dances.

They were all Balubas, a docile and interesting people, whom I made it my duty to protect, not only against the violence of the whites, but against the thieving, rascally Bakussus who infested the region. I must confess that the only pang of regret I ever felt in quitting the Congo I experienced on leaving these people, as they trooped down, wailing in their native fashion, on the riverbank to bid me farewell. Among them was a woman of great intelligence, named Ilanga, who spoke the Swahili language well, and who, in response to my request, had told me in a straightforward and simple manner the story of the capture of herself and her companions. The truth of the narrative was proved, not only by the presence of these unfortunate people, but later by an officer and the Likwangula soldiers who had effected their capture, and who were later sent to garrison my post in anticipation of a possible attack by the mutineers of Baron Dhanis's Nile expedition. This was the story of Ilanga :-

"Our village is called Waniendo, after our chief Niendo. It is only ten days' walk from Nyangwe, and only one day from the water of the Lomami. It is a large village near a small stream, and surrounded by large fields of mohago (cassava) and muhindu (maize) and other foods, for we all worked hard at our plantations, and always had plenty to eat. The men always worked in the fields clearing the ground, or went hunting, or made madiba (a coarse kind of cloth made of the fibre of the oil-palm leaf). We never had war in our country, and the men had not many arms except knives; but our chief Niendo had a gun, which he had bought long ago from another chief for forty-three beads, but he had no powder or caps, and only carried it when he went on a journey.

"About a moon before we came here we were all busy in the fields hoeing our plantations, for it was the rainy season, and the weeds sprang quickly up, when a runner came to the village saying that a large band of men was coming, that they all wore red caps and blue cloth, and carried guns and long knives, and that many white men were with them, the chief of whom was Kibalanga, 
(Michaux). Niendo at once called all the chief men to his house, while the drums were beaten to summon the people to the village. A long consultation was held, and finally we were all told to go quietly to the fields and bring in ground-nuts, plantains, and cassava for the warriors who were coming, and goats and fowls for the white men. The women all went with baskets and filled them, and then put them in the road, which was blocked up, so many were there. Niendo then commanded everyone to go and sit quietly in the houses until he gave other orders. This we did, everyone remaining quietly seated while Niendo went up the road with the head men to meet the white chief. We did not know what to think, for most of us feared that so many armed men coming boded evil; but Niendo thought that, by giving presents of much food, he would induce the strangers to pass on without harming us. And so it proved, for the soldiers took the baskets, and were then ordered by the white men to move off through the village. Many of the soldiers looked into the houses and shouted at us words we did not understand. We were glad when they were all gone, for we were in much fear of the white men and the strange warriors, who are known to all the people as being great fighters, bringing war wherever they go. Our head men were asked if they had seen or heard anything of some Batatelas whom the white chief was anxious to catch; but nothing had been seen of them, and only a rumour had come that the Batatelas were fighting the white men.

"When the white men and their warriors had gone, we went again to our work, and were hoping that they would not return; but this they did in a very short time. As before, we brought in great heaps of food; but this time Kibalanga did not move away directly, but camped near our village, and his soldiers came and stole all our fowls and goats and tore up our cassava; but we did not mind that as long as they did not harm us. The next morning it was reported that the white men were going away; but, soon after the sun rose over the hill, a large band of soldiers came into the village, and we all went into the houses and sat down. We were not long seated when the soldiers came rushing in shouting, and threatening Niendo with their guns. They rushed into the houses and dragged the people out. Three or four came to our house and caught hold of me, also my husband Oleka and my sister Katinga. 
We were dragged into the road, and were tied together with cords about our necks, so that we could not escape. We were all crying, for now we knew that we were to be taken away to be slaves. The soldiers beat us with the iron sticks from their guns, and compelled us to march to the camp of Kibalanga, who ordered the women to be tied up separately, ten to each cord, and the men in the same way. When we were all collected-and there were many from other villages whom we now saw, and many from Waniendo-

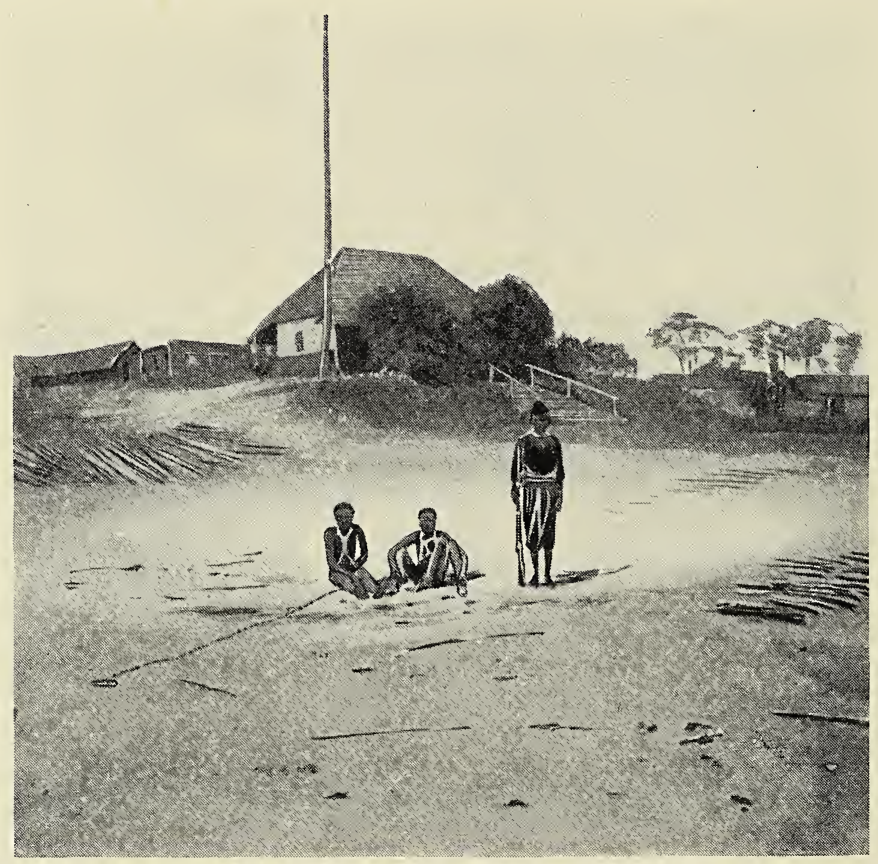

PRISONERS IN CHAINS, WITH PORTIONS OF HUMAN BODY TIED ROUND THEIR NECKS, STANLEY FALLS.

(a)

the soldiers brought baskets of food for us to carry, in some of which was smoked human flesh (niama na nitu).

"We then set off marching very quickly. My sister Katinga had her baby in her arms, and was not compelled to carry a basket; but my husband Oleka was made to carry a goat. We marched until the afternoon, when we camped near a stream, where we were glad to drink, for we were much athirst. We had nothing to eat, for the soldiers would give us nothing, so we lay upon the ground, and at night went to sleep. The next day 


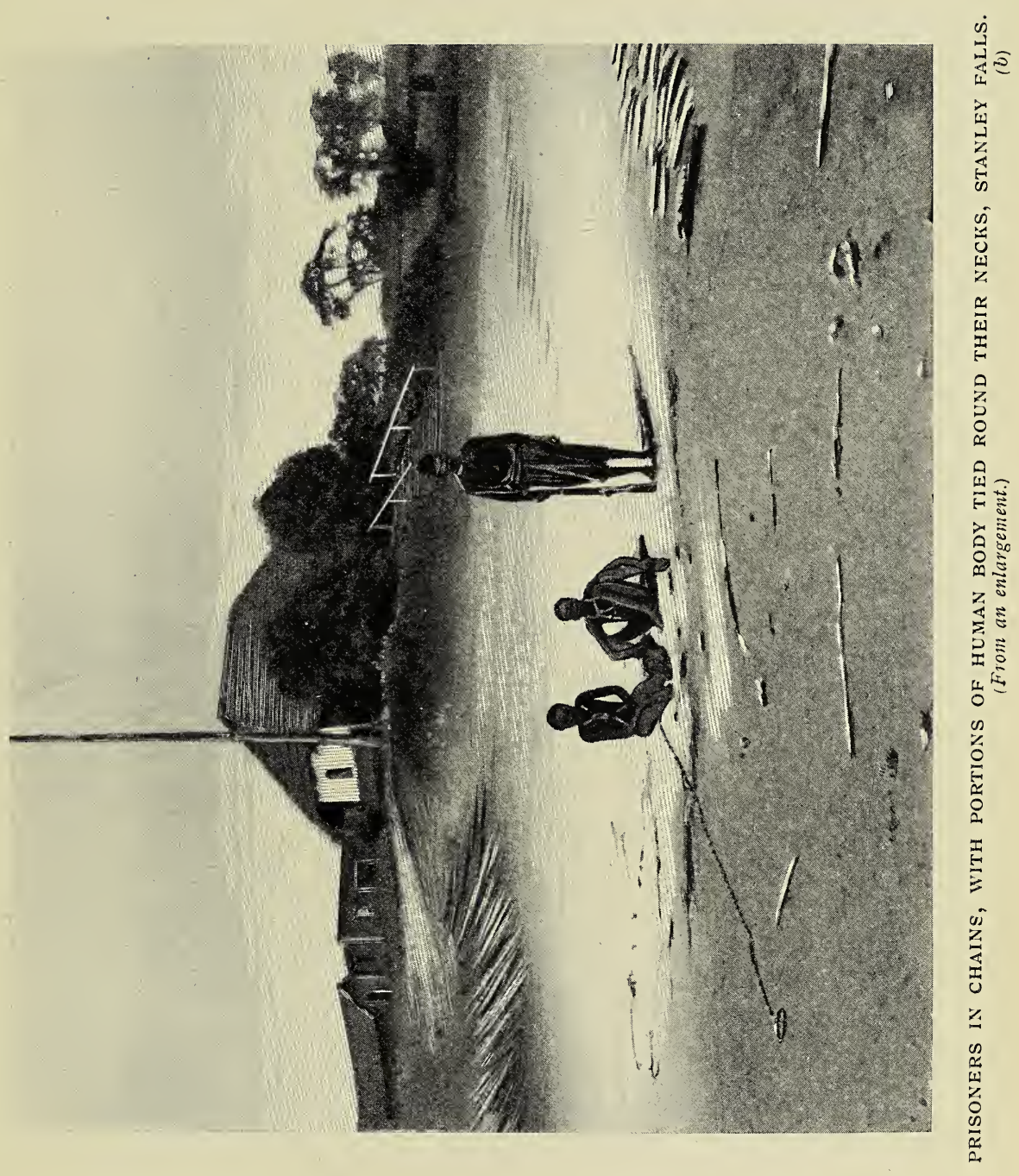


we continued the march, and when we camped at noon were given some maize and plantains, which were gathered near a village from which the people had run away. So it continued each day until the fifth day, when the soldiers took my sister's baby and threw it in the grass, leaving it to die, and made her carry some cooking-pots which they found in the deserted village. On the sixth day we became very weak from lack of food and from constant marching and sleeping in the damp grass, and my

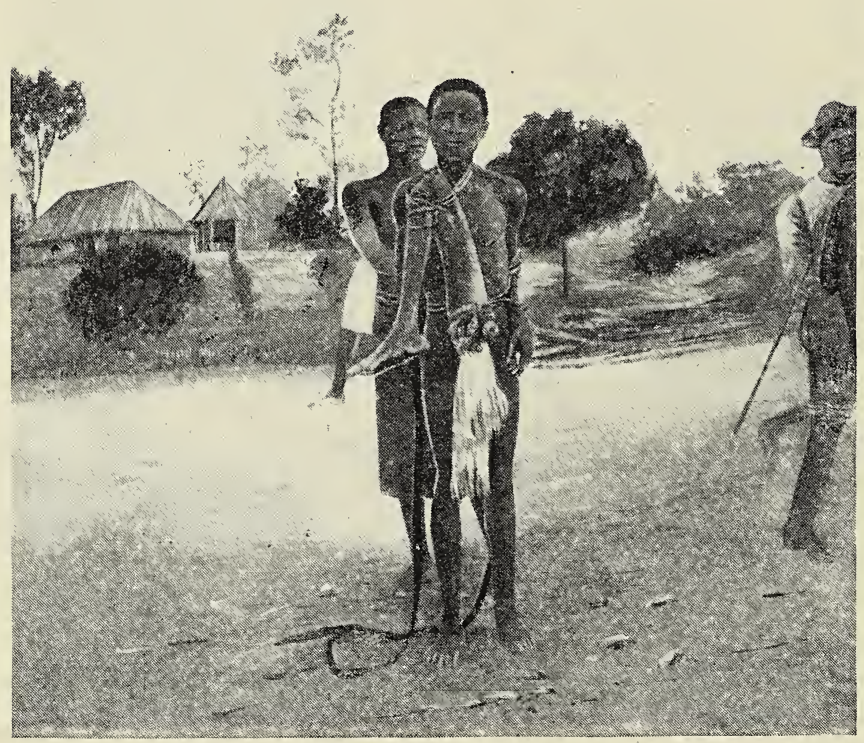

PRISONERS IN CHAINS, WITH PORTIONS OF HUMAN BODY TIED ROUND THEIR NECKS, STANLEY FALLS.

(c)

husband, who marched behind us with the goat, could not stand up longer, and so he sat down beside the path and refused to walk more. The soldiers beat him, but he still refused to move. Then one of them struck him on the head with the end of his gun, and he fell upon the ground. One of the soldiers caught the goat, while two or three others stuck the long knives they put on the ends of their guns into my husband. I saw the blood spurt out, and then saw him no more, for we passed over the brow of a hill and he was out of sight. Many of the young men were killed in 


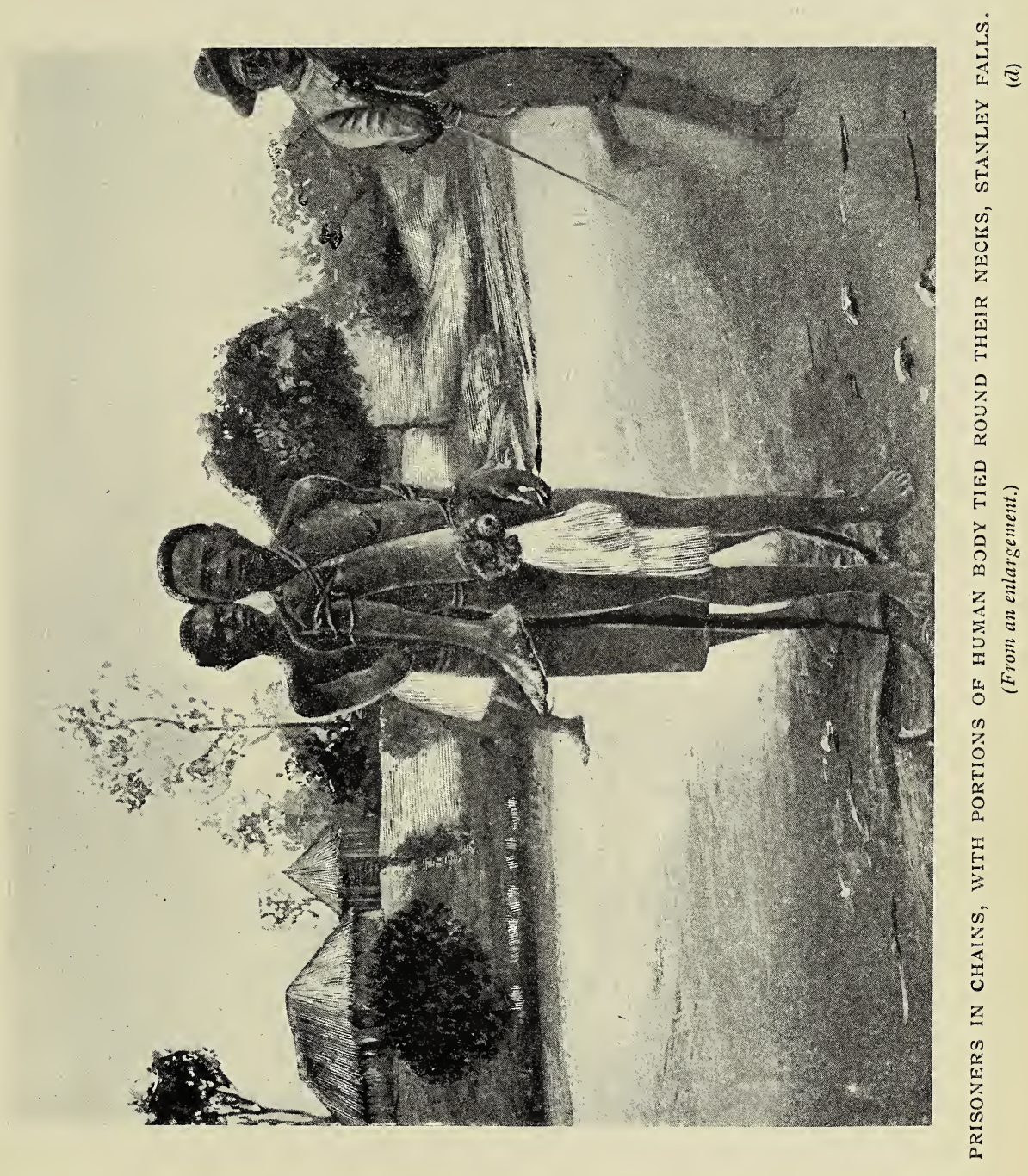


the same way, and many babies thrown into the grass to die. A few escaped; but we were so well guarded that it was almost impossible.

"After marching ten days we came to the great water (Lualaba), and were taken in canoes across to the white men's town at Nyangwe. Here we stayed six or seven days, and were then put in canoes and sent down the river, as we supposed, to Zingatini (Stanley Falls); but on the way we could get nothing to eat, and were glad to rest here, where there are good houses and plenty of food; and we hope we will not be sent away."

I promised the Balubas that they should remain, and they proved their gratitude by working very hard on the plantations. Nor did I ever have any difficulty with them, but found them always willing and most obedient. I never detected one of them guilty of theft, although they had many opportunities to steal. I occcasionally purchased cloth for them from the stores on my own account, for the State is not over generous to its slaves. Many batches of these people were sent down to Stanley Falls, where they were distributed among various posts requiring labour. This is not an isolated case of slave-raiding by the Belgian officials and officers; such occurrences are frequent throughout the Congo, for the example set by the State is only too readily followed by the companies.

The State agents have few duties more harrassing than those of hunting down fugitive slaves and returning them to their masters. Nearly all the disputes among the natives and the followers of the Arabs are caused by mutual slave-stealing. Much of the time of the post commanders is devoted to these disputes, for no sooner does a slave run away than his master sets off at top speed to the station to inform the white man. "Master, my slave has been stolen!" he cries; "send quick your soldiers to bring him back!"

Half-an-hour is required for the interrogation of the excited slave-owner, generally with the result that he admits that the slave has run away, but that So-and-so is harbouring the fugitive in his village. To the latter, therefore, a soldier is sent, with instructions to bring to the post both the slave and his protector. A court (mancno) is then held, and, if the claimant is proved to be the runaway's owner, the man is forthwith handed over. 
By an unwritten law, and under pretext of respecting moeurs indigènes, the slave system is rigorously upheld by the officials of Bula Matari. The war waged against the Arabs of Tippoo Tib was less for the suppression of the slave trade than in order to acquire their country, with its large slave population and great extent of rubber-producing forest. Half the stations of the Upper Congo have been built by slaves from the Manyema, and their garrisons have been supplied with wives from the same source. As far down as Leopoldville one may hear gangs of women singing in Swahili as they ply their hoes in the fields of the white man.

Probably the most cruel method of forcing the natives to bring in rubber is that employed in the Province Orientale, or eastern part of the State. Here the territory is divided among the Arabs or Arabised natives, the latter usually belonging to the bloodthirsty Bakussu tribe. Each of these Arabs, who are called "auxiliaries," has a band of cut-throats, armed with muskets belonging in part to the State, which also furnishes ammunition, and to them is entrusted the duty of compelling the natives to furnish rubber. This task, it is unnecessary to add, they perform with great zeal, for it affords them opportunity, under pretext of acting as agents of Bula Matari, of massacring and pillaging to their heart's content. Many of these Arabs who came under my observation busied themselves less with the collection of rubber for the white man than with the levying of tribute on the natives for their individual benefit.

It may be argued that the State does not approve of these proceedings. If that be so, why do the officials trouble themselves to keep these marauding bands supplied with arms and ammunition-a fact that cannot be denied. I have myself, at the instigation of higher officials, dealt out to them firearms of various descriptions, including breech-loaders. Since the occupation of the Upper Congo and the formation of the Force Publique, there has been a long carnival of massacre, and it is my opinion that the population has been sensibly reduced.

Should the natives refuse to submit to the awful exactions of the officials or company agents, they are said to be in "revolt," and bands of cannibal soldiers are sent to punish them, which they do with atrocities beside which the Bulgarian and Armenian outrages fade into insignificance. For the Turk some excuse may be 
found on the ground of religious fanaticism; but on the Congo these gruesome proceedings are the outcome only of lust of gain. Since the inception of the Domain Prive, the Belgians, while placing great value upon their own lives, regard those of the natives as worthless.

In the days of Tippoo Tib and the Arab dominion, great slave raids or "razzias" were conducted by these gentry, and thousands
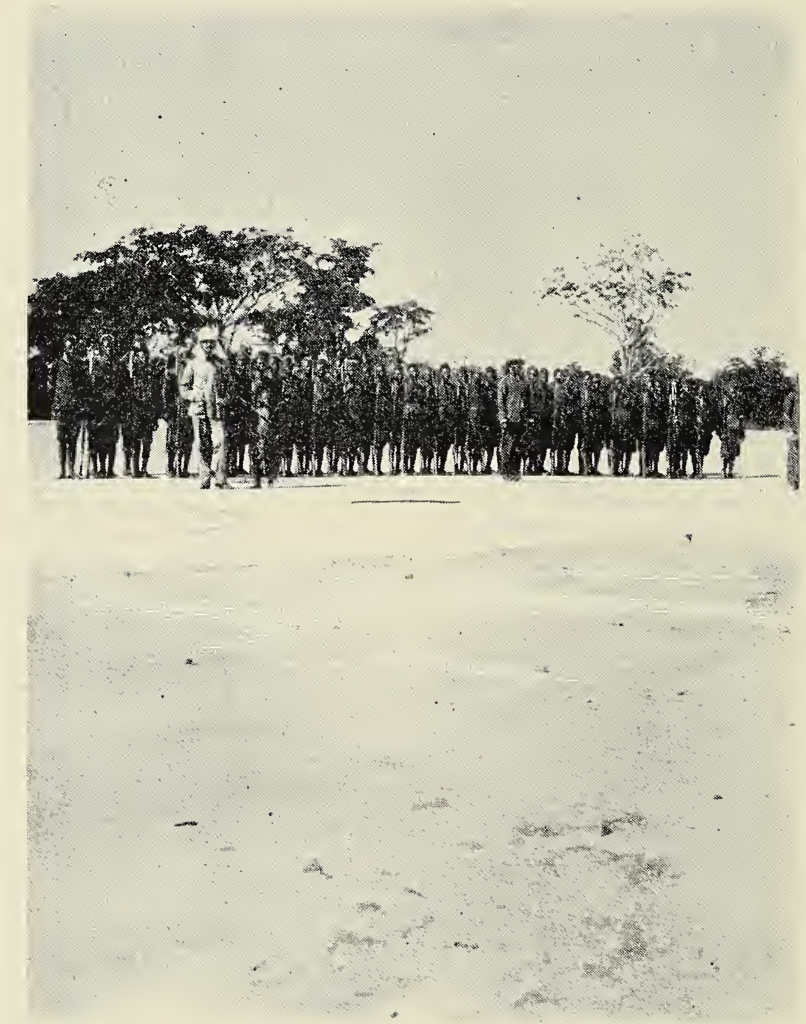

capt. bell (Killed, With Nearly all the above soldiers).

of natives were killed or carried off into slavery; but I venture to say that no Arab chief ever managed the business on so vast a scale as some of the officials of the Free State. I have had under my orders hundreds of poor creatures who were compelled, halfstarved and naked, to build the stations and work the plantations of Bula Matari. I have seen them flogged until the skin was so lacerated that horrid sores were the result, and the victims were 
then forthwith compelled to continue labour under the lash of a brutal soldier.

Not only does the State itself engage in capturing slaves, but it encourages and officially protects the traffic. On the Lualaba I have seen hundreds of large canoes coming down from Nyangwe and Kassongo laden with slaves packed together like sheep. The Arab or his niampara in charge of the convoy was armed with

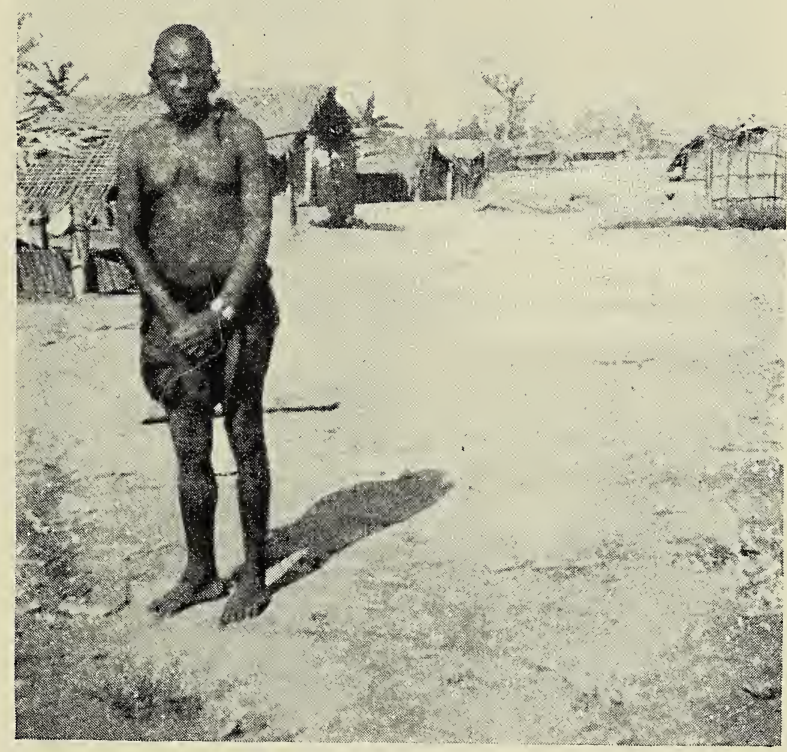

A BASOLO CHIEF.

an official passport signed by the commissaire de district, and bearing his official seal. These passports generally set forth that the bearer was authorised to "recruit" labour, and all agents of the State were required to aid him. Of course, as there is no voluntary labour in the country, the Arab purchases his cattle in the cheapest market. For that he is generally abundantly supplied with cloth, the price per "recruit" ranging from two to ten "doit" 
(a doti is two fathoms). The Manyema, on account of its denser population, has long been a favourite "recruiting" ground; but since the close of the Arab war in 1895 the slave crop in that district has not been so prolific.

This is not surprising when one recalls the massacre of so many thousands of the followers of Muni Mohara and Sefu. Not fewer than 3,000 men, women and children are said to have been slaughtered in the town of Nyangwe alone after the place was taken by the State troops-commanded by Baron Dhanis-and their savage allies under the native chiefs Gongo Lutété and Lupungu. A vast mob of slaves, deprived of their masters by death or flight, was seized and transported to Stanley Falls, whence they were sent into the wilderness of the Ituri to form stations and villages. Here also many of them died, as the result of privations induced by the uninhabited, and therefore uncultivated, character of the region.

The maintenance of the personnel of the stations costs but little, for it depends on the application of the universal principle of placing the burden of everything upon the natives. The villages nearest to the State stations are obliged to furnish quantities of food, for which they receive nothing, though they are generally exempted from the duty of rubber-gathering. This system, called "impositions," bears very heavily on many of the villagers, who often have scarcely sufficient for their own needs. Thus has the King of the Belgians been enabled to carry on his venture; for had the expense fallen upon him and his fellowspeculators they would speedily have tired of the enterprise. 


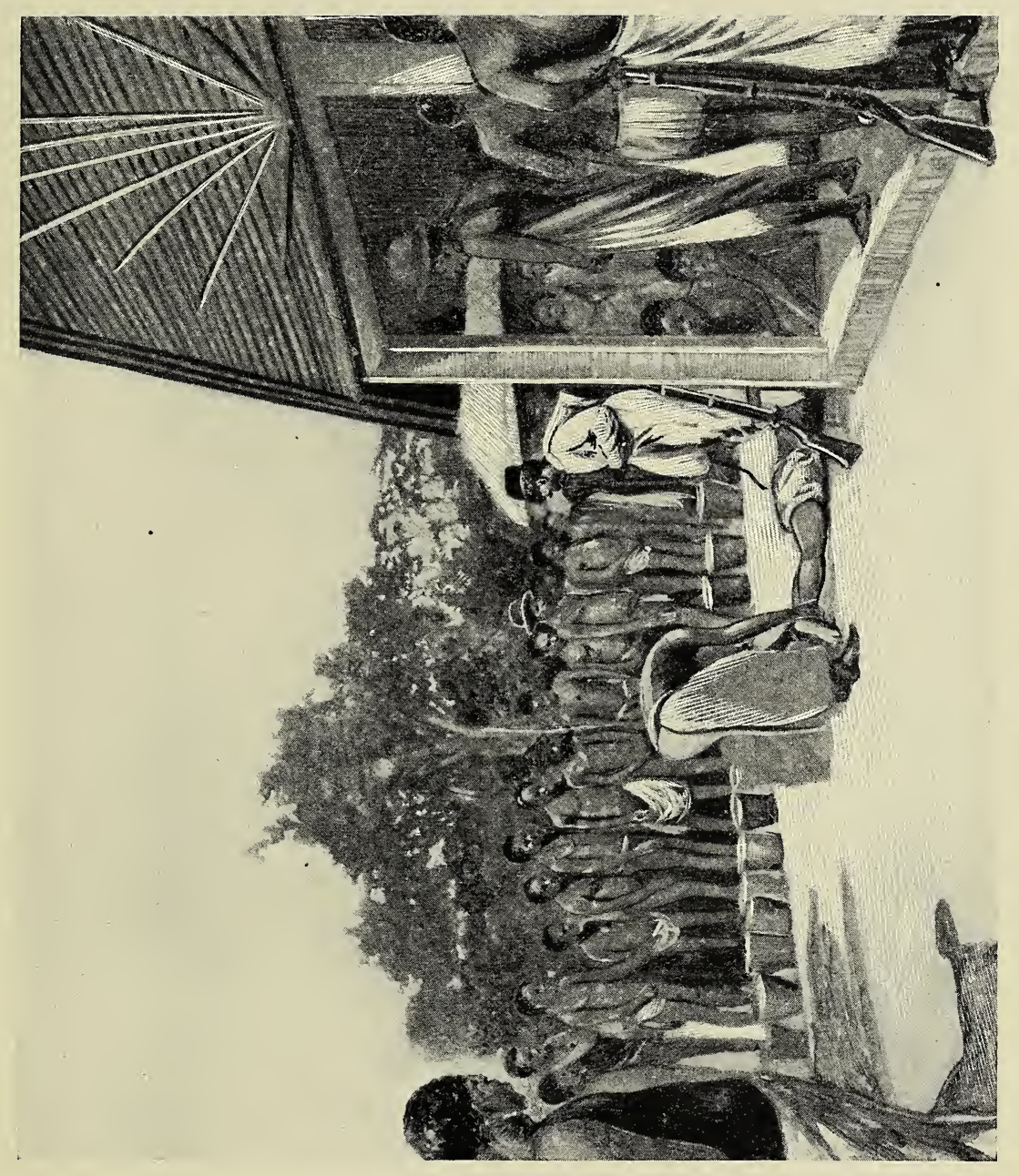

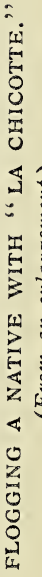




\section{CHAPTER XVIII.}

Isangi-A Pleasant Station-M. Baltus, Director of the Isangi Company-The Trouble with M. Hottiaux-His Revenge-His Departure-A Commission of Inquiry-I open Court at Isangi-The List of Charges-Encouragement of Cannibalism-How He Paid His Carpenters-Women in the Bush.

Aвоuт sixty or seventy miles up the Congo from Basoko is Isangi, an important trading station and headquarters of the Isangi Company, which has a monopoly in the district. Isangi is situated at the junction of the Lomami and the Congo. It is a very pleasant place, fairly well built, and certainly picturesque. The country is inhabited by the Topoke, who were the victims in the story of brutality with which this chapter deals.

I often visited M. Baltus, the director of the Isangi Company, and sometimes on business of the State, sometimes as a private caller, I used to sit with him on the verandah of his house. One day when I was sitting chatting with the director, his assistant, M. Hottiaux, appeared before the verandah. The director had just given him instructions to visit a certain post with thirteen soldiers, armed with Albini rifles-these soldiers being in the employ of the company. For some reason or other M. Hottiaux did not want to go; I think he was afraid, for he was not a very courageous person. This was grave insubordination. The director once more ordered him to go. He refused again, whereupon M. Baltus dismissed him on the spot. M. Hottiaux disappeared from the verandah, and in due time from the station.

When he arrived in Boma he went straight to the Administrator-General's office and lodged the most violent accusations against $M$. Baltus, his late chief, who had dismissed him. In a terrible tale of atrocities $\mathrm{M}$. Baltus was accused of fearful crimes towards the natives and towards the whites alike. Then, having made his deposition, M. Hottiaux left Boma for Europe. 
The Commissioner at Boma sent me the details of Hottiaux's complaint, and as commissioner of the district it was my duty to inquire into them. Accordingly I subpœnaed the necessary witnesses, and began to inquire into the conduct of M. Baltus; but it soon became clear from the evidence that the man whose conduct needed enquiry was M. Hottiaux. Accordingly I closed the case against $M$. Baltus and held an inquiry into the actions of M. Hottiaux who, out of spite, had accused his late chief of the very actions, as I found afterwards, that he himself had committed. M. Baltus then told me all he knew of M. Hottiaux, and as a

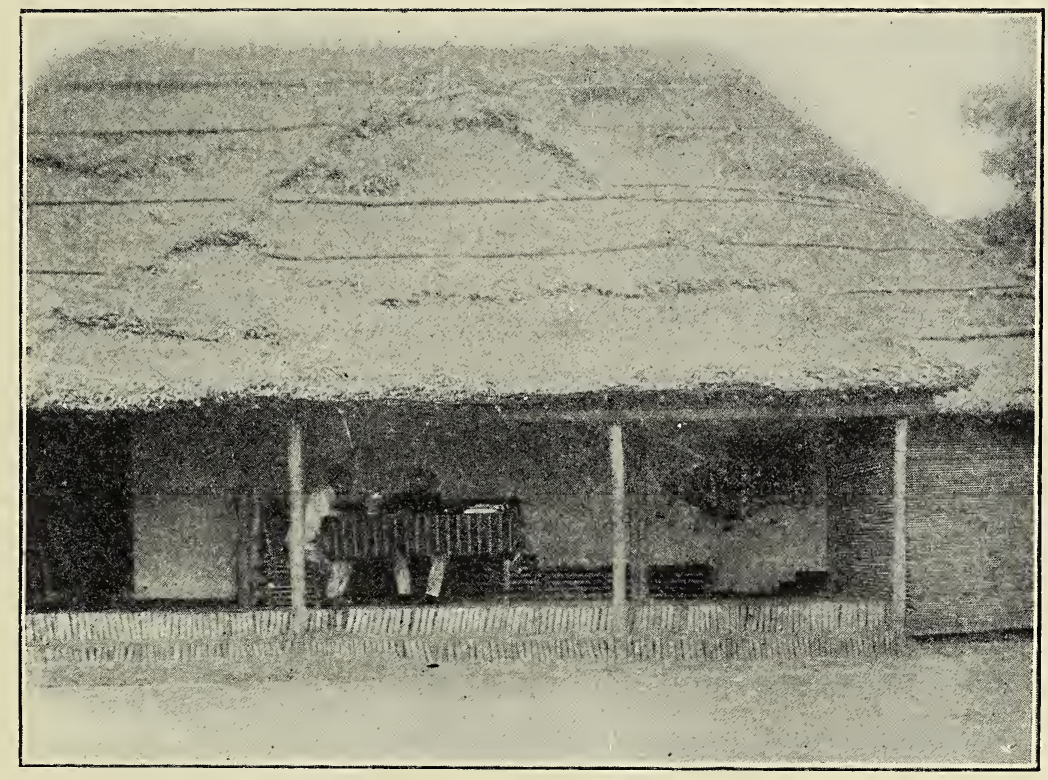

UMANGI.

result of this I instituted a formal inquiry at Isangi. There being no regular public prosecutor, the evidence was taken on oath and sent to Boma.

On the 26th day of January, 1901, I opened the court at Isangi. The court-house was the verandah of the director's house. I had with me a certain number of State soldiers to keep order and act as policemen. The other white officials were a barrister who acted as Procurator of State, or public prosecutor, a clerk of the court, and an usher. 
The list of charges against M. Hottiaux was read out in French and in the native tongue current at Isangi-the Bangala. The proceedings of the court were conducted in French, but the witnesses were examined in the vernacular, all of the officers who formed the court being proficient in that language. This again was recorded in condensed form in French.

The list of charges against M. Hottiaux, all of which I think were satisfactorily proved, make very unpleasant reading, the more because they are by no means uncommon in the annals of Belgian administration. They are :-

1. That he gave to the natives at Hondo the man named Tongu-Turru, telling them to eat him. (This happened at Mossengé.)

Witnesses:-Liombera; Chief of Hondo; Chief of Malinda; the woman, Andelwami.

2. That he caused the death, at Ligasa, of his boy, in that he caused him to be beaten with blows of a bludgeon by the workpeople till death ensued.

3. That he caused to be killed, at Ligasa, the chief of the village of Yabussunga, and gave his corpse to the chief of Malinda:

4. That he caused to be assassinated, at Ligasa, a dozen prisoners of the village of Yacoco, and gave the corpses to the chief of Malinda.

5. That he gave to the chief of Hondo and another chief several prisoners from various villages, as payment.

Witnesses to 2, 3, 4, and 5 :-Liombera; Andelwami ; Chief of Malinda ; and other witnesses who did not appear at Ligasa.

\section{Procès Verbal.}

In the year one thousand nine hundred and one, on the 26th day of the month of January.

Before the officers of the public ministry, appeared under oath :-

FIRA, ONE OF THE CHIEFS OF HONDO.

Were you at Hondo during the period during which M. Hottiaux (mafuta mingi) resided in Mossengé?-Yes.

Do you know the name Tongu-Turru?-Yes, I knew him. 
What has become of the man in question?-This man went down from Mossengé to look for boatmen for M. Hottiaux (mafuta mingi), and during the carrying out of this task he shot two men at the village of Massanga, chief of Hondo. We arrested the man Tongu-Turru and led him to the house of M. Hottiaux (mafuta mingi) at Mossengé.

What did M. Hottiaux (mafuta mingi) do with this man?He gave him the lash, and afterwards handed him over to the chief of Hondo (chief Massanga) to be eaten.

Did you meet M. Baltus (tala tala) when you were on the road with Tongu-Turru towards Mossengé?-No. M. Baltus (tala tala) crossed us on the road, but we did not see him.

Did the chief Massanga kill and eat this man?--Yes, he killed and ate him.

$$
\begin{aligned}
& \text { The Witness :- } \\
& \text { X (a cross). }
\end{aligned}
$$

SCHWIND, CHARLES, COMMERCIAL AGENT OF THE ISANGI COMPANY.

Since when and up to what date were you with M. Arens at Yombiti?-I was with M. Arens from the month of January to the month of July, 1900, as assistant at the post of Yombiti.

During your stay with $M$. Arens at Yombiti, did you have any knowledge of a native being shot by the order of M. Arens?Never.

Were you in a position to know all that happened daily at the post of Yombiti?-Yes, I was well informed regarding everything that happened at the post.

Did you ever know that regular elephant hunts used to be made at the post of Yombiti?-No, I have never even heard tell of them. During my stay I have never seen anyone but the natives themselves bring ivory into the post.

During your stay did any of the natives ever come with a complaint about the white men at Yombiti, or the white men of the neighbouring posts?-No.

During your stay did you ever see that there was regularly a string of forty natives, male and female, on a chain?-No.

Signed by the Witness :-

Schwind. 
ANDELOIME, WORKMAN AT LIGASA.

Were you in the service of M. Hottiaux (mafuta mingi) at the post of Ligasa?-Yes.

Did you know the boy Lutombe?-Yes, he was in the service of M. Hottiaux as boy. M. Hottiaux one day tied him up to the flagstaff of the pavilion, and he summoned the natives (gambes) to kill him with blows of a bludgeon.

Why did M. Hottiaux (mafuta mingi) have the boy killed?Because he had returned to his native village (Hondo).

Was there another white man at the post when M. Hottiaux killed the boy?-Yes, M. van de Putte (Kassongo) was at the post. M. van de Putte's boy ran away with M. Hottiaux's boy, but he only received a flogging as punishment.

Did you know the chief of Yabussunga?-Yes.

What happened to this chief ?-He was shot at Ligasa.

The Witness :-

$\mathrm{X}$ (a cross).

FIRA, CHIEF OF HONDO.

Did you know anyone named Lutombe?-Yes, he was my brother, and he was in the service of M. Hottiaux (mafuta mingi).

What happened to your brother who was in the service of M. Hottiaux (mafuta mingi)?-The white man killed him.

How did M. Hottiaux (mafuta mingi) kill your brother?-He had him tied to the flagstaff of the pavilion, and called the staff of the post to kill him with blows of bludgeons.

How did you learn of this deed?-I was present with my brother, named Moisa.

Why did you not make a complaint either at Isangi or at Basoko?-I wanted to go and make a complaint at Basoko, but M. Hottiaux (mafuta mingi) threatened me with death if I should make a complaint, and afterwards he gave me forty pieces of stuff in order that I might not make a complaint at Basoko, and I was afraid to make it.

What did M. Hottiaux do with the body of your brother?He gave it to the natives of the neighbouring village to be eaten.

The Witness:-

$\mathrm{X}$ (a cross). 


\section{LIAMBA, HEAD OF MALINDA.}

When M. Hottiaux (mafuta mingi) was head of the post at Ligasa, did you work for him?-Yes, I furnished him with leaves for roofing the houses, and my men worked for the station.

Were you paid for your work?-Yes.

With what were you paid-with cloth, with beads, or with brass?-I was paid with the corpses of the prisoners killed by M. Hottiaux (mafuta mingi).

How do you know that these men were killed by the order of M. Hottiaux?-Because I was present at the massacre, and because I saw the place where the corpses were hidden at the time of payment.

Did M. Hottiaux ever give you living women or children?Yes, he gave me six women and two men.

What for?-In payment for rubber which I brought into the station, telling me I could eat them, or kill them, or use them as slaves-as I liked.

The Witness :-

$\mathrm{X}$ (a cross).

LIOMBERA, CARPENTER TO M. HOTTIAUX.

Did you know the man Lutombe?-Yes, he was boy to M. Hottiaux while I was at Ligasa as carpenter.

What happened to Lutombe?-One day he ran away with the boy of M. de Putte (Kassongo). He was brought back again by the natives, and M. Hottiaux had him tied up to the flagstaff of the pavilion, and had him killed with blows of bludgeons by the natives. M. de Putte's boy only received corporal punishment. The boy Lutombe was disinterred that evening by the natives, and was eaten by them.

Do you know the chief of Yabussunga?-Yes, he was named Libulambila, and was a prisoner at Ligasa. One day, when he tried to run away, he was killed by order of M. Hottiaux (mafuta mingi), who was head of the post at the time.

Did you see any prisoners at Ligasa?-Yes, I saw a great many taken.

What did M. Hottiaux do with the natives who were taken prisoners?-Some of them were given to the natives to be kept as slaves, or to be eaten, at the will of the chief. 
Did you know that some prisoners were killed at the post?Yes, nine men and two women of the village of Yacoco, prisoners at the post of Ligasa, had their throats cut with the little native knives, because M. Hottiaux (mafuta mingi) was afraid to have them shot lest they should be able to learn of this at Basoko.

What was done with the bodies of the eleven men killed at Ligasa?-M. Hottiaux (mafuta mingi) had them thrown into a large pit, and paid the natives for their work with these corpses, saying, "Take them and cut them up."

Do you know of any other similar occurrence?-Yes, when going on a journey to Yabusio with M. Hottiaux. We met two women on the way, and two men shot them by order of the white man. The women fled, wounded, and M. Hottiaux himself fired, wounding one woman in the back with a bullet that went right through her.

Was the woman dead from this shot?-No, the woman was carried off by the white man. On the following morning the woman was unable to walk, owing to the gravity of her wound, and was despatched, at the white man's order, by the chief of Malinda, who cut her throat

The Witness:-

$\mathrm{X}$ (a cross).

LIOMBERA, CARPENTER AT MOSSENGÉ.

Were you in the service of M. Hottiaux (mafuta mingi) at the post of Mossengé in 1898?-Yes.

Did you know the man Tongu-Turru?-Yes.

What became of the man Tongu-Turru?-He was sent as messenger by M. Hottiaux to Isangi, and was brought back to the post by the natives of Hondo, who had disarmed him because he had killed two natives. The white man had him flogged, and then gave him to the natives of Hondo as repayment for the two men killed.

Was M. Hottiaux alone at the post of Mossengé when the man arrived?--Yes, and it was he alone who gave the man to the natives to be eaten. 
When at Basoko, I had occasion to try a Belgian by courtmartial for flogging women. I would not allow any of them to touch women, and succeeded in suppressing that absolutely. Half-a-dozen were flogged every day before I reached the post. I proved that, by witnesses, to the State authorities when M. Costermans came up to make an inquiry.

In 1898 , just when I went up to Upoto, a substitute for the public prosecutor arrived there, going up to inquire into the massacre of 150 natives who had been killed close to Upoto. They secured as auxiliaries a number of natives, who came because they were given the bodies to eat, and the loot and women. Mr. Smelts, the missionary there, went out and saw the remains after the massacre, and he told me of it.

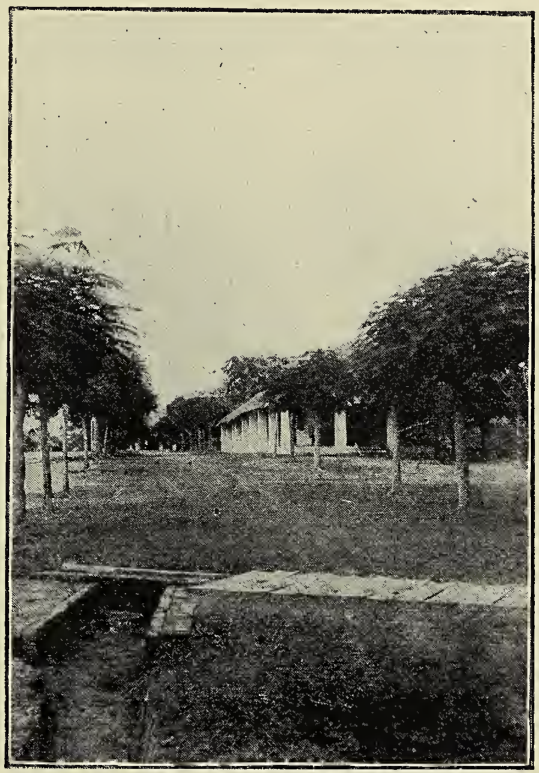




\section{CHAPTER XIX.}

THE STATE AND THE FUTURE.

The Central and Local Governments-The Real Purport of the Codes-Some of the Judicial Dignitaries-To Right the Wrong-An Appeal to the Emperor William-Suggested Partition of the Congo Basin-Great Britain's Responsibility-The Question of the Bahr-el-Ghazel.

THE Congo Free State is a despotism pure and simple, unfettered by checks other than those suggested by international obligations and pressure of public opinion-both, as we have seen, very lightly esteemed. The principal affairs of the State are regulated by the so-called Central Government at Brussels, comprising departments of Foreign Affairs, Finance, and the Interior. At first each department had at its head an Administrator-General, but after September, 1891, this title was changed for that of Secretary of State, and since September, 1894, there has been but one official so designated. This gentleman, Baron van Etvelde, is assisted in the execution of his duties by a Chef de Cabinet, TreasurerGeneral, and three departmental secretaries.

There is also a local Government, with headquarters, since 1886 , at Boma. It is probable, however, that this place will not long remain the capital of the State, for already there is talk of removing the administrative offices to a more healthy and certainly more central location overlooking Stanley Pool. To the GovernorGeneral are delegated administrative and legislative powers of the most elastic and far-reaching character, for he directly represents the King-Sovereign, and has authority over all departments, including even that of justice. He is assisted by a Vice-Governor-General, one or more Inspectors of State, a Secretary-General and several Directors, and is also supposed to enjoy the benefit of advice from a Comité Consultatif, which includes the officials already named, a Judge of Appeal, the Commissioner of Land Titles, and a certain number of other dignitaries. 
The Civil and Penal Codes of the State are more or less confused collections of orders and decrees by various officials, and even the judiciary often finds itself at a loss to obtain therefrom a clear idea as to the exact meaning of the law. The real laws governing the conduct of the whites, who are for the most part the paid servants of King Leopold, are contained in the "regulations" which impress upon them the necessity of making rubber and plenty of it. The "regulations" are executed through the commissaires de district, who are, however, allowed abundant latitude in the interpretation thereof. Thus the decrees of the Sovereign and his Governor-General may be carried out in as many different ways as there are commissaires de district.

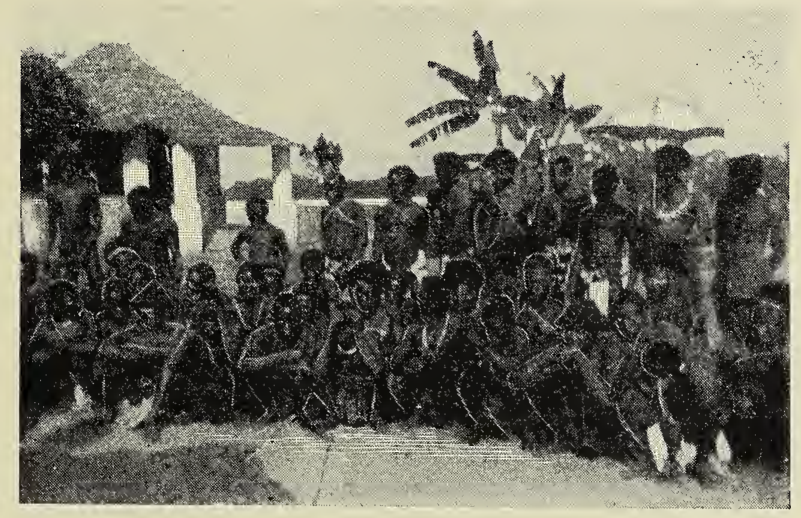

NATIVES, BASOKO.

At the chief station of each district, and in some districts at the headquarters of each zone, a court-martial is established to try criminal cases. Appeal is permitted from the decisions of these courts-martial to a superior court-martial sitting at Boma. Any region may be declared under martial law at any time, and appeal to Boma is permitted only to civilian whites-a right, by the way, denied to the late Mr. Stokes.

The judiciary consists of a Conseil Supérieur sitting at Brussels, and chosen from among King Leopold's favoured officials. This is the Supreme Court, from whose decision there is no appeal. A part of its duties is to administer the different codes in a manner most favourable to the interest of the "State." 
A Court of Appeal at Boma hears appeals from the decisions of the Territorial Courts which are established in the chief stations of the different districts. The judges in these courts, who generally bear the imposing title of Substitut du Procureur d'Etat, appear to fill quite a variety of offices-detective, policeman, jail-keeper, and prosecuting and defending counsel, as well as judge-and, considering the pittance which Bula Matari pays, no doubt work sufficiently hard. I have seen some very "queer fish" among the judges, many of whom have a failing for absinthe and other strong liquids. Their principal ambition seems to be to make the sum total of the fines they impose as large as possible. One of the agents of the Mongalla Company was fined $£ 8$ for boxing the ears

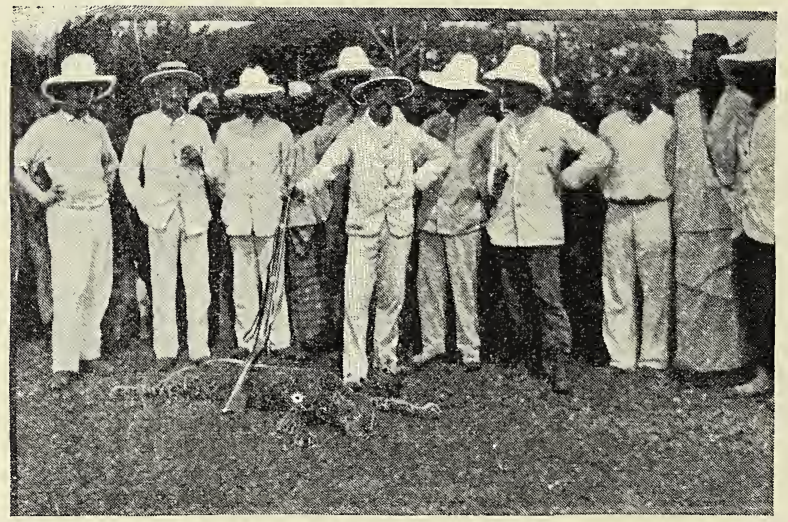

AFTER A LEOPARD HUNT, BASOKO.

of an insolent cannibal policeman at Matadi. The judge appointed to make inquiry into the atrocities committed in the Mongalla concession is said to have obtained his information by sending his "boy" among the native staff of the "factories," and, on his reports, to have arrested a number of white men. To vary the monotony of his voyage in those benighted parts, he engaged in a little quiet trading for ivory, much to the disgust of the company's traders. In short, the entire judicial system is a farce, mainly intended to create offices and blind the eyes of the public to the proceedings of the State in the far-off jungle.

It may very properly be asked-is there no way of preventing further excesses, and in a measure undoing some of the evils which have sprung up with the rule of avaricious monopolists? 
The Congo question is, in some of its aspects, the most dangerous and difficult international problem of the moment. This, however should not deter the Powers, who are certainly not blameless in the matter, from attempting a solution. It is argued that the present is an inopportune time for diplomatic action to that end, and that were any Power to move in the matter the floodgates of international jealousies would at once be opened. This is the official view, a normal one in the face of difficulty, and always very emphatic when there is a great wrong to be righted. One thing, however, the Cabinets appear to forget, namely, that the longer the question is permitted to remain unsettled, the more arduous will become the task of diplomacy. Sooner or later, for very shame, the Powers will be compelled to fairly face the situation; and it appears to me that it were better to do this now than wait until their responsibility to outraged humanity is augmented and the political horizon is overcast from this very cause.

To the Berlin Conference of 1885 the European nations and the United States are indebted for the ignominy of having collectively sanctioned the creation and continued existence of that governmental monstrosity, the Independent State of the Congo. To a second gathering of the representatives of the Powers in the same capital most of us look for an attempt to atone for the misplaced confidence of the first. There presides to-day over the destinies of Germany a monarch of exalted views, most catholic sympathies, and unrivalled energy, who is the master of mighty legions, but the pledged guardian of peace, whose personal influence in the councils of nations is greater, perhaps, than was ever exercised by a single man. He has already achieved much for his own people and for the cause of civilization; for each he may do more; but all humanity would be his debtor were he to take initial action towards securing for the downtrodden millions of Central Africa those blessings of equitable rule which his and other Governments have unwittingly but surely denied them.

What would another African Conference signify, and what could it effect? It would show that the conscience of the Powers had awakened; that the nations had determined that ruthless massacre and rapine should cease; and that if the peoples, or 
adventurers, adjudged guilty of malpractice did not forthwith mend their ways, they would be deprived of further opportunity for ill. The vast basin of the Congo, it is not uninteresting to note, readily lends itself to a scheme of partition among the three principal Powers possessing the adjoining territories. Nothing could be more easy than to find natural frontiers to the territories thus divided. The British frontier could be made to follow the waters of the Congo along its entire length from the point where the Lukungu takes its waters from Tanganyka to the present Portuguese frontier below Matadi. The German border could follow the same line as far as the junction of the Aruwimi and the Congo, thence following the course of the former to its source, and thence due east to the western shore of Lake Albert. The present frontiers between the British East African possessions and German East Africa could be readjusted to run from the southernmost point of Lake Albert to the northern point of Lake Victoria, following for a considerable part of the distance the course of the streams. To France would go the entire territory on the north of the Congo from Banana Point to the Aruwimi, following this river to the 27th degree of east longitude to the extreme eastern point of French occupation on the Uelle. To Egypt could be assigned the remaining fragment, including the Lado enclave and the Bahr-el-Ghazel, bringing the Egyptian border from the extreme easterly French line along the 27th degree of east longitude to the Aruwimi, and along the German line to Lake Albert.

Until the government of these vast territories is taken from the hands of a people so eminently unfitted for the task as the Belgians, and placed in those of Powers who have the means and the will to conduct it on civilized lines, there will be no amelioration in the condition of the millions of the native races.

Great Britain's responsibility is perhaps greater than that of the other Powers signatory to the Berlin Act, because it has been instrumental in adding to the territories of the Congo State, and even availed itself of the services of the latter and its cannibal mercenaries. The so-called Lado enclave and the adjacent territory in the Bahr-el-Ghazel were long assumed to be within the British sphere of influence in East Africa, but the claim had not been supported by such effective occupation as the Berlin 
Conference prescribed when Lord Rosebery's Government, in 1894, granted the Congo State a lease of the Bahr-el-Ghazel district. The proposed consideration for this act of misplaced generosity was a cession by the Congo of a portion of its territory bordering German East Africa, this being desired as a link in the, at that time, much talked-of Cape to Cairo railway scheme. Germany, however, objected to Great Britain as a neighbour on the north of Lake Tanganyka, while France protested against the cession to the Congo State of so much of the yet unappropriated country north of the Ubangi River which she had long coveted for herself. For these reasons, the AngloCongolese compact was abandoned except as regards the Lado

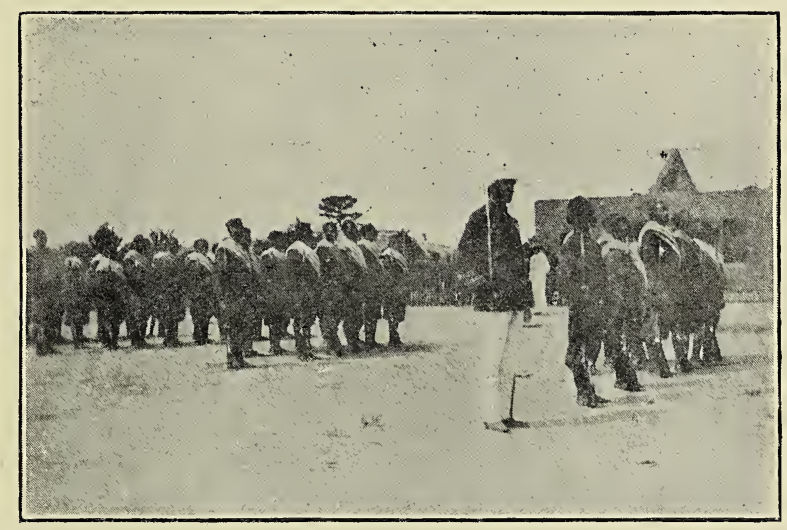

COMMANDANT MATHIEU.

enclave, and it was in taking possession of this territory that the State provoked the mutiny of its Batatela troops to which reference has already been made in these pages. A portion, however, of the Congolese army was able to give some assistance to Britain during the latter's reconquest, for Egypt, of the eastern Soudan, and also in blocking that march from the French Congo to Somaliland by which Lieutenant Marchand aspired to secure for France "effective occupation" of a trans-African route from the Atlantic to the Indian Ocean.

These incidents were in a measure terminated by the Convention of May, 1900, in which France recognised the claim of Great Britain, as guardian of Egyptian interests, to such ownership as it 
could establish over the Bahr-er-Ghazel, which, however, the Congo State still claims by virtue of the uncompleted compact of 1894 . For some time the State has been preparing for the exploitation of this territory, by presumably the same methods which have wrung wealth from the Mongalla and other regions recognised as under King Leopold's sway. If such be tolerated, England will have assumed even greater responsibility for the evils of the Congo Administration than any of her co-signatories of the Berlin and Brussels Acts. A nation ready to sacrifice the blood of her best and bravest in order to endow a few cosmopolitan adventurers with the doubtful advantage of the franchise in a country where their lives and property, at least, were respected, can surely raise a finger in defence of the rights of millions of the black races of Africa.

THE END. 


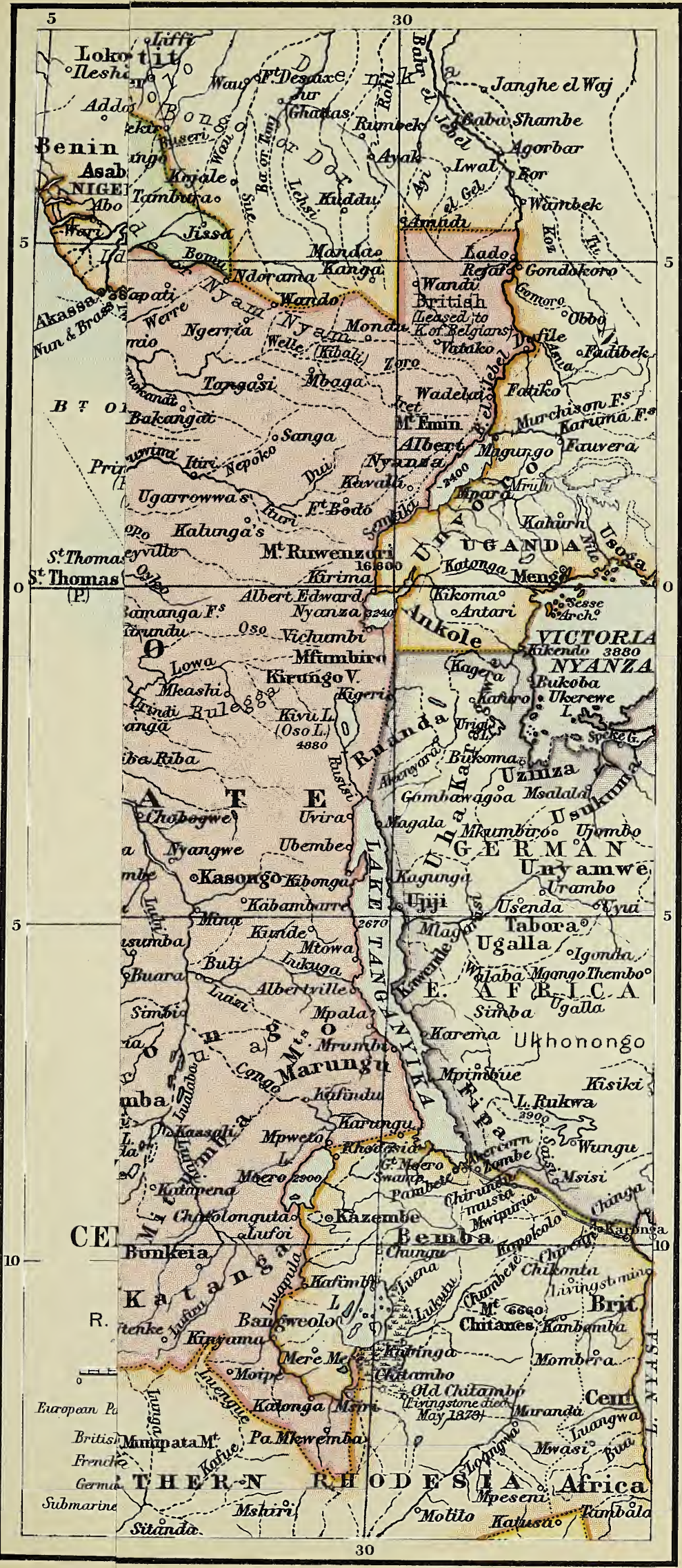





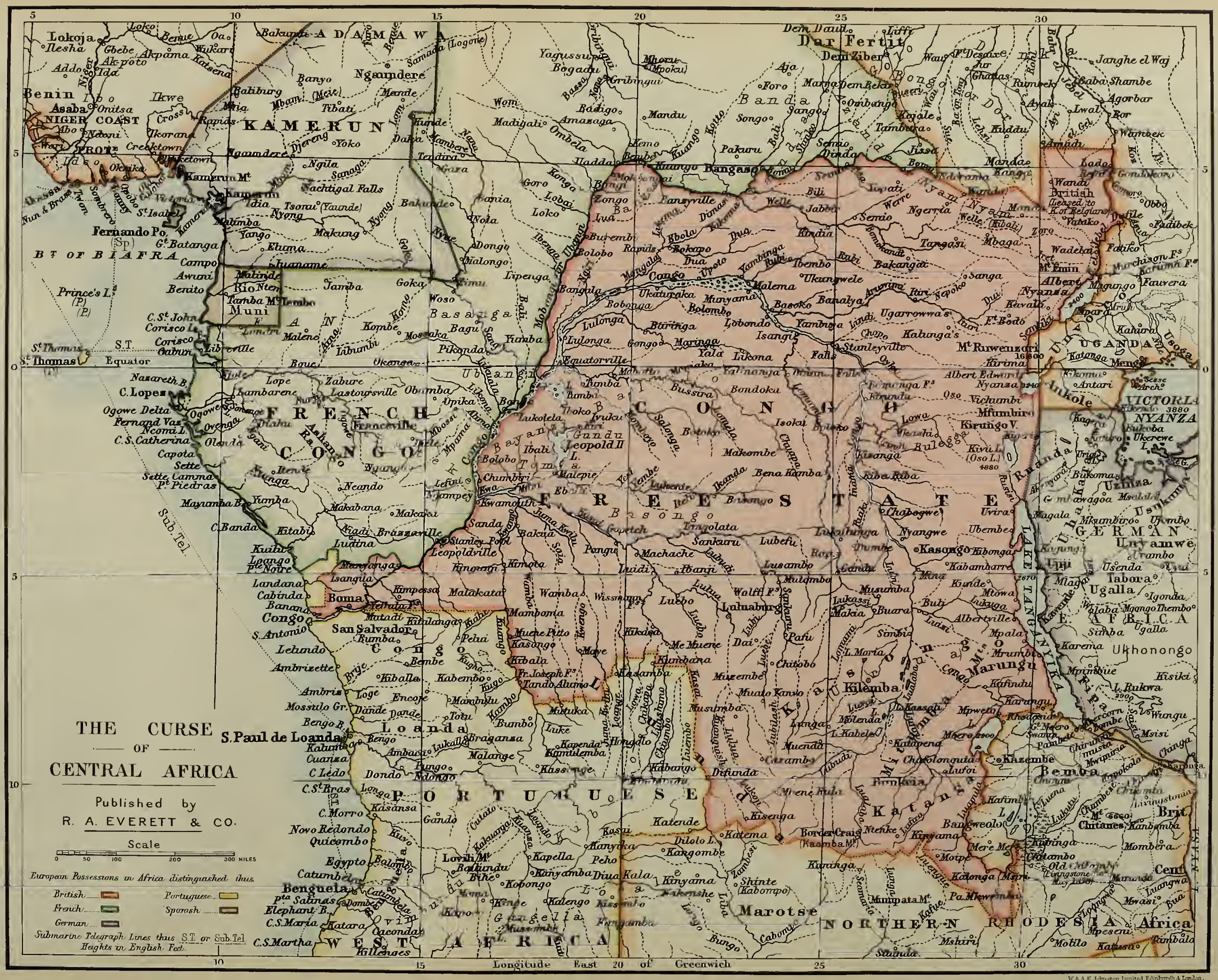






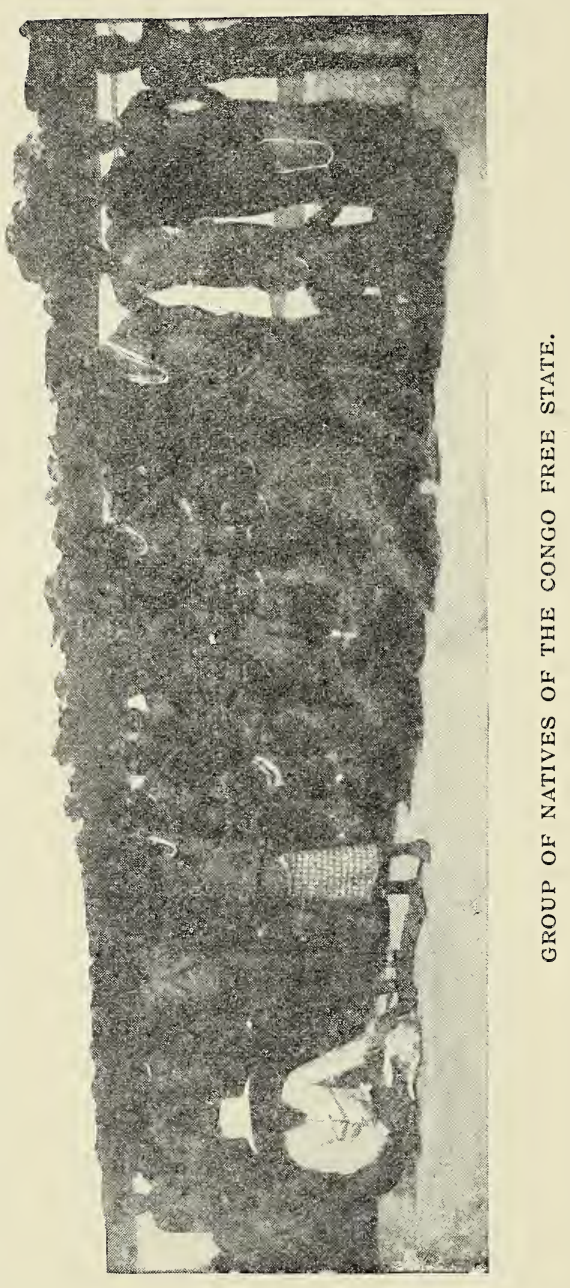


A P P E N D I X. 



\section{REPORT OF CAPTAIN G. ANDREWS JONES, LATE CAPITAINE DE STEAMER III. CLASS ETAT INDEPENDENT DU CONGO.}

THE terrible atrocities that are the common talk of the white population of the Congo Free State, did not come to any great extent under my personal observation, although I served sixteen months in the service of the State in command of one of their vessels on the Upper Congo. At the same time I had exceptional advantages of meeting people who were travelling up and down the rivers, and a day seldom passed without my hearing of revolting atrocities committed by State officials, who, if they were not acting under orders of their superior, at least escaped any punishment, and were decorated by the King on their arrival at Brussels. My memory does not serve me to remember the names and localities in connection with the majority of these crimes after the lapse of two years; but one case I remember particularly well. The facts were related to me by a member of the American Baptist Mission at Luebo, who went over the ground and saw the result of the fiendish work with his own eyes.

The chief of the Zone, a Lieutenant at a place called Luluabourg, acting presumably under orders, armed some hundreds of the Zappo-Zap tribe with rifles and ammunition, and gave them instructions to collect ivory, rubber and slaves from the neighbouring tribes. No white man was sent with these savages, who are avowedly cannibals, and the most warlike and bloodthirsty tribe in this part of Central Africa. The chief of the Zone must have known what must inevitably happen.

In fact he must have anticipated and intended it, for the Zappo-Zap chief afterwards showed my friend a basketful of right hands, which he said he had orders to take back as proof that he had performed his task.

The quantity of rubber and ivory demanded from them, these poor people were quite unable to supply, for the simple reason that they did not possess it. The Zappo-Zap then proceeded to murder the people, burn the villages and make slaves of all the younger women. Whole tracts of country where there had once been peaceable villages were devastated in this way. My informant himself saw the ruins of the village and great numbers of dead natives. In many cases the fleshy parts of the bodies had been cut off and eaten. In one place a stockade was built into which the headmen of the neighbouring villages were invited for a palaver; when all were inside the opening was closed, and these State-armed fiends proceeded to shoot them down at their leisure, practically exterminating them. My friend remonstrated with the Zappo-Zap chief, but was told he was acting under the orders of the chief of the Zone. He then went to the chief of the Zone and demanded in the name of God and humanity that this ghastly work should cease. But that official denied all knowledge of what was happening, although it was only a few miles 
from his station. A complaint was then made to Boma and an order was given that the Zappo-Zaps chief should be sent down to that place; but the big chief of the tribe said he would resist, by force if necessary, any attempt to arrest his subordinate chief who had only carried out the orders of the chief of the Zone. So nothing further was done in the matter, the Lieutenant in charge of the Zone being left in that position.

With regard to the flogging of women, I believe the law prohibiting this is only a few years old, before which it was a common practice; but like all State laws it exists only on paper for their own protection. I have heard of one Commandant who now has command of an important district, having had a woman that he kept for immoral purposes, stripped and flogged with a twisted thong of dried hippo-hide for some minor offence. I mention this as a sample of many others. I think the whole system of flogging natives for every little offence is most brutal and degrading. I myself have been ordered to have a man flogged by the King's Commissioner, Major Michel. I asked for what reason. I was told he was a bad man; at least he looked like a bad man, he had a bad face. I was compelled to obey this order, which was one among many things that made me refuse to remain in their service for my full time. I believe one of the conditions under which the State was taken over was that it was to be effectively policed. But I have no hesitation in saying that in my district no man's life was safe, particularly that of a State official a few miles outside a station. Yet when Stanley went through the country the people were friendly and peaceably inclined. They have simply been driven to desperation by cruelty, robbery, and wholesale murder. Their women and children have been taken from them as slaves, and made to work on the plantations, with a soldier with a stick to drive them until they dropped dead in their chains. The better favoured of the women have been taken, with or without their consent, by the State officials and used for immoral purposes.

Their treatment of white men, other then Belgians, is in some cases not much better, as witness the case of the Capitaine Adjoint of the State vessel "Ville de Bruxelles," a Scandinavian who came down sick with fever. He was put on board an old hulk called the "Ville de Paris" which was in a filthy and unsanitary condition. The only food supplied to him had to be fetched from the mess by a small native boy, and consisted principally of goat's flesh in a cold, greasy mess, which, of course, a man in his weak condition could not eat. After some delay, the doctor of the station came to see him, and was asked to give an order for some milk to be supplied to him. He refused, and a brother officer, Captain Millor (a Dane) alarmed for the man's life, went to M. Inspector Costermans, and asked if another medical man could be sent. This request was granted, and the doctor from the laboratory was sent. He at once said, "I have been called too late. The man has been starved to death." The sick man died shortly afterwards. The doctor was, I believe, sent to Boma, but I do not suppose he was punished.

At Leopoldville there are some hundreds of white men in the State employ, yet, in spite of the place being one of the most unhealthy in the world, there is no hospital. There were indeed, when I left, three huts which were used for this purpose and are dignificd by the name of hospital, but there were no attendants or nurses, merely the four walls and a bed. The doctor visited these huts generally once a day. I was unfortunate enough to be an inmate of one of these for a time. I was supplied with a small native boy to fetch my meals from the mess about a mile away, but he 
was not allowed to stay all day. He was regularly taken away and put to work on the beach. When he went to mess for food he was kept waiting until the meal was finished; he was then given portions of what was left, which more often then not appeared to be scrapings of the mess-table-goat's flesh, stewed grass, and jam tart being mixed up together in one greasy abominable mess on one plate. This was, I think, hardly the sort of food to help a man to recover from black-water fever. I, however, thanks to a sound constitution, recovered sufficiently to leave this death-trap. I need hardly say the majority of the tenants of these huts are not so fortunate. The cemetery at Leopoldville tells its own.sad tale.

I think the death of poor Lieut. Bullinger, an English officer in the military service of the State, should at least be inquired into. I met this poor fellow in Leopoldville, where he was, at one time, a prisoner on board the State vessel "Princesse Clementine." He told me he had been sent down from a station up the river, on several grave charges, of which, he stated, he was entirely innocent, and that he was going to Boma for trial. He had no fears of the result of that trial, if it were conducted in a fair and proper manner. He had plenty of witnesses. He was in excellent health at the time, a strong, hearty man, who had served in the Bechuanaland Police. He was sent to Boma, and although he remained there some time, and repeatedly applied for trial, the authorities would not hear him. The last I heard of the poor fellow was that he had written a letter to an assistant at the English store in Boma, saying "They are coming to-night to give me an opiate, make a note of this." The next morning he was dead. No firing party or Belgian official attended the funeral, not even the doctor. One cannot help contrasting this with the treatment accorded by the State to the Belgian officer, Lieut. Lothaire, who murdered the Englishman, Stokes. Every one knows that he is now the director of a large company, which is a thinly-veiled State monopoly. He is courted and made much of by State officials at every station, and is treated as a sort of hero.

I think it is high time our Government took some steps to safeguard British subjects in the State. There are thousands of natives from the West Coast (British subjects) in the employ of the State. These men can neither read nor write, for the most part, and when they claim that their period of engagement has elapsed, they are invariably told "Oh no, you have yet another year to serve." They apply to the missionaries for advice, but of course, they can get no help there, and as the State will not give them money they are obliged to stay.

G. ANDrEws Jones,

(Late) Capitaine du Steamer III. Class Etat Independent du Congo 


\section{RE PORT OF Mr. ARNOLD H. MALET, ON THE CULTIYATION OF COFFEE AND COCOA.}

\section{Basoko and Limputu.}

These two plantations being contiguous may be dealt with together:-

The soil is perhaps a little better here than at the other Postes. In places there is quite a respectable amount of humus. Nevertheless, it is not nearly rich enough for the successful cultivation of cocoa.

At Basoko the ground has been properly cleared, there being few shade trees left. Consequently there are signs of very abundant crops, but a great deal too many trees have been left at Limputu, which should be cut down while the coffee is still young, as much damage would not be done there. Considering the nature of the soil the weeds here have been well kept under. Even since my arrival here a month ago, much has been done; this is chiefly because the Chef de Culture here is the only man I have yet seen who knows anything about his work. The older trees are in a disgraceful state, never having been pruned since they were planted. I have no hesitation in saying that were fifty pruning knives or secateurs to be sent here the result of the pruning would more than double the crop. The trees have become so "matted" that no sun c an get at the bearing branches and consequently the coffee is prevented from flowering.

For the rest the coffee is looking wonderfully well and healthy, and, given proper tools, this plantation should give good results.

MACHINERY.-There is a small "Heuller" here which will possibly be sufficient to husk the coffee until the end of this year. Next year additional machinery will be required. But this machine alone is incapable of preparing the coffee for the European market, and the extra machines, such as polishers and sifters, will also be wanted.

\section{Barumbu.}

It is with much pleasure that $\mathrm{I}$ am able to give a totally different report on the soil here. It is a light, fairly rich chocolate loam, with not too much clay in it, and well suited to its purpose.

It seems to me a great pity that coffee should have been planted here as it is the only place I have yet seen really suitable for cocoa cultivation. The land being undulating and even steep in parts, therefore more sheltered against the wind, adds also to its value. There is a small nursery of cocoa plants ready to plant out, but unfortunately they are not very good specimens. They have also been left unshaded for some time.

If it be intended to extend the cultivation of cocoa here I would strongly recommend that new seed $_{2}$ be imported for the purpose, and, above all, not the seed from S. Thomé. The variety grown in this island, and, I understand, planted throughout the Congo, is that known as Calabacillo Amarillo, and obtains the lowest price of all the varieties of cocoa in European markets; the only advantage the Calabacillo has, is its power to grow in soil that is not rich. 
COFFEE. -All the coffee growing here is growing well and is extremely strong and healthy, but it is "running up" instead of forming lateral branches on account of the excessive number of shade trees. These shade trees are in most cases palms, and coffee will never produce big crops while these trees remain. No doubt fine healthy trees will be formed, but while these look very nice they do not bring in money in the shape of crops. The coffee, therefore, must be closely watched and topped as soon as the trees show signs of growing disproportionately. There are very few vacancies in the coffee, but the suckers and small offshoots want attending to badly. The weeds here are, as usual, very bad. But this is greatly owing to the insufficient labour supply. There is enough work here for an extra 50 women for some time, and it should be undertaken at once to prevent the place becoming like Magandjo. I noticed that near the residence of the Chef de Poste a considerable amount of ground nuts maize was growing amongst the coffee. This is altogether an unnecessary exhaustion of the soil, as there is ample room for these behind the house.

The new land being cleared is being as well done as can be expected.

The most pressing need of this plantation is a thorough system of drainage. The land being very steep in places, every heavy shower washes away a considerable amount of humus. Fifty extra men, with the necessary tools, should be sent to commence this work at once to preserve the best part of this plantation. It must also be remembered that the washing away of the top soil lays bare the lateral roots of the coffee, which in its turn is often torn completely out of the ground by a heavy downfall of rain. I have even seen old trees washed away on well-drained land which has been rather steeper than usual. This is the one bright spot in this district, where an experienced planter (not a gardener) could make a successful paying plantation.

\section{Bomaneh.}

The soil is pretty much the same as at Mogandjo. It will possibly support coffee for eight to ten years, but is totally unfit for cocoa cultivation.

The trees are all young, it being impossible to tell as yet what the crop prospects are. There are very few vacancies, but here again suckers and gormandizers are very much in evidence, and no attempt seems to have been made to remove them. I am informed by the planter that the reason of this is that he is unable to obtain the necessary knives to work with. These should be supplied without delay, as the longer these damaging offshoots are allowed to remain the weaker the tree itself becomes in proportion. A great many nut-palms are left standing amongst the coffee. It is simply a question whether the palm oil or the coffee is more valuable to the State, as both are unable to thrive together. There are a number of old tree stumps supporting parasitic life which should be cut up and burnt, and the large number of anthills are nearly all covered with small bush, which it is dangerous to allow to exist in coffee, harbouring as it does all kinds of pests, such as grasshoppers, locusts, slugs, etc., and which do so much damage among the young plants.

The roads are in good order, but the drains on either side might be enlarged as the slightest rain chokes them.

I notice plantains and bananas have been planted on each side of the roads here. This is a wise proceeding, which might be carried out on all plantations, as they form excellent wind-breaks as well as being a food supply. 
The old plants in the nurseries here, having become too large for transplanting safely, should be thrown away.

On the whole, the plants are healthy, and with care this should turn out to be quite up to the average plantation here.

The cocoa is not worth keeping, as it will never do well here.

\section{Mogandjo.}

The soil here is somewhat better than at Yambuya, there being more humus, and although the subsoil is a stiff clay, it commences at a greater depth than elsewhere on the river, probably owing to the higher elevation of the land at this point.

I regret to have to remark that the preparation of the land for the planting of the coffee has been most scandalously done. Trees have been left standing in clusters, many of them positively harmful to any cultivated plant, and without any attempt at any regularity or system, so that in places the coffee is far too thickly shaded and in others there is no shade at all. The brushwood or undergrowth has been most carelessly cleared, the roots of the same not having been properly exterminated, so that now in certain parts of the plantation it has grown up again nearly as thick as the original. In fact, the clearing of the whole place shows that whoever did it knew nothing of his work. The most serious question here is that of the weeds. They are so bad in places, especially the parts of the plantation furthest away from the houses, that the young plants are being slowly killed-choked to death in fact. Unless they are relieved very speedily a large number of plants will be lost altogether. It was impossible to inspect these plants properly as the weeds prevented them from being seen. The lack of sufficient labourers is the chief cause of this state of affairs, some 200 extra will be required for at least six months to put things in order again. Another cause is the lack of system and knowledge displayed by the successive planters who have had charge of the place.

I will admit that some parts of the plantation are very difficult to keep clean, and only continued frequent weedings will ever bring about that desirable end. The roads are in bad order, being overgrown with weeds also.

On the whole, the coffee is as healthy as can be expected under the unfavourable circumstances in which it has to exist, but I noticed that a large number of trees showed signs of having considerably from the standard of the original stock, probably owing to their being the result of unripe seed, which seed again was most likely taken from young trees.

A peculiar feature is the excessive number of young suckers that appear on all trees. These cannot be too rigorously kept down. To improve the quality of the coffee I recommend that, as soon as the trees can stand it, severe pruning be undertaken, or a decent, saleable coffee will never be obtained, All the older trees should be pruned at once, as they are growing up without proper regard to shape and formation of crop-bearing wood. There is no reason why an average plantation should not be obtained here, provided the planter be properly directed and the necessary labour put at his disposition.

Cocon.-By a curious contradictory state of affairs, the Cocoa, which it is absolutely necessary to shade, has been planted in the only place where all the trees have been cut down, whereas the coffee which requires no shade, has it. The trees 
have a miserable straggling appearance, and the leaves are, without exception, eaten to shreds by insects, chiefly a species of grasshopper and a cricket, which appears to feed at night time only.

The soil is not rich enough for the successful cultivation of this product, and I doubt if the crops would obtain a price sufficient to cover the cost of placing them on the market. If the cultivation of cocoa is to be continued here, I would recommend that Manihot Glaziovii (Ceara Rubber) be planted as shade, and that the trees be pruned.

\section{Yambuya.}

The top-soil here is nearly pure mud, with a small amount of humus on the surface, the sub-soil being a stiff yellowish clay. I caused several holes to be dug in various parts of the plantation. In each case water was met with, generally at a depth of $\mathrm{I}$ metre, and in no place deeper than $\mathrm{I} \frac{1}{2}$ metres, thus proving the whole place would be unfit for the cultivation of plants, whose tap-roots would penetrate that depth.

The place has been badly cleared, a great many trees being left standing, most of them useless for shading purposes and without any regard to regularity or system, but here and there in groups.

The young coffee trees have not been well planted, numbers not being in line, and there are a great many vacancies that should have been supplied long ago. Nearly all the plants are fairly healthy, owing to the stimulating effect of the small quantity of humus their roots now feed in, but when they have to begin to force their way through the stiff wet clay they will at once rot.

The weeds here are very rank, in some places so high that the young coffee cannot be seen. Two causes can be assigned for this state of affairs, viz:-lack of sufficient labour, and ignorance on the part of the responsible men as to the proper methods to be followed in weeding a tropical plantation. The older plants have not been topped and the small suckers and gormandizers have been allowed to run up to very large proportions. These ought to be stripped off as soon as they make their appearance, as they do great damage to the trees when they have to be cut off later. There are a number of plants in the nurseries which are now too large to be planted out with safety. These might be destroyed.

CocoA.-This is the only plantation where I have seen cocoa shaded. Bananas have been used for this purpose here with the happiest results, although this shade would be useless, after the trees were years old. The cocoa is healthy, fairly well formed, and the leaves are not riddled by the depredations of insects. It is a great pity to think that in two or three years, when the tap-roots reach the water below, such promising plants will be suddenly killed. But because these plants are healthy it must not be taken as a proof that the soil is suitable for cocoa. It is merely the humus which gives it this impetus and by the time trees are old enough to bear a crop the humus will have been exhausted.

Taken on the whole, I do not see any profitable future for this plantation. Large quantities of manure would have to be used before paying crops could be obtained, and then the stiff clay sub-soil and the water difficulty remain.

I would recommend that the Manahot Glaziovii or Ceara Rubber be planted, as the swampy nature of the ground should suit it admirably,

Arnold H. Malet.

(Copied from the original in the possession of the publishers.) 


\section{SOCIETE ANONYME D'AGRICULTURE ET PLANTATIONS AU CONGO.-DIRECTION IN AFRICA.}

\section{Monsieur le Directeur.}

Ligassa, I6 August, I899.

In reply to your letter of the $\mathrm{I}^{\text {th }}$ inst., I have the honour to bring to your notice the grave matters which occurred at Ligassa during the stay of M. Vandeput.

This agent committed several murders, the precise details of which were given me by the soldiers in garrison at Ligassa, are as follows :-

Ist. Murder of a boy.-M. Vandeput's boy, a native of Ilondo, named Lotombé, after having suffered a long time his master's illtreatment, ran away from Ligassa.

Being caught and brought back, the child (who was not eight years' old), was killed by the native workmen of the villages of Olea and Yabussunga, who each in turn struck the child with sticks until death supervened. M. Vandeput, who had ordered this cruelty, had first made them tie Lotombé to a large log of wood, so as to prevent his struggling.

According to the natives, this child's sufferings lasted several hours.

2nd. Assassination of the Chief of Yabussunga, named Etuambela.-After the massacre of the Auxiliaries, stationed in the villages of Yakoko and Olea, the Chief of Yabussunga was made a prisioner by Bulafia and Tchopé, who were stationed in his village. After having been brought to Ligassa and imprisoned, he made an attempt to escape. The soldier, Méga, who was that day on guard, was ordered by M. Vandeput, with a threat of roo strokes of the whip, to kill the Chief, who was struck down by two balls. This agent had the head of the Chief brought to him to make certain of the crime.

3rd. Murder of a native Workman of Yakoko.-A native who attempted to strike a sentry was brought in to the Station by the soldier. M. Vandeput struck the man on the head with a stick, stunned by the blow, the man fell to the ground, but in a few moments, got up and tried to run away. M. Vandeput ordered the five soldiers with him to fire on the man. After being shot down, the white (M. Vanderput) himself gave the body to the people of Ligassa to eat.

(Signed) The Manager,

LOSANGE.

** The above complaint was made by the agent Losange, against M. Vandeput who had at that time gone down river. MM. Vandeput and Hottiaux were stationed together when the occurences narrated happened. It is noticeable that, Losange accuses only Vandeput (who had just left the district), and makes no mention of Hottiaux who must have been present, vide evidence before Court of Enquiry-but then M. Hottiaux was still in Africa, and a member of the Isangi Company to which M r. Losange belonged. Verb. Sap. 
I N D E X. 



\section{INDEX.}

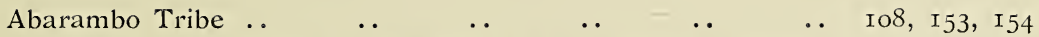

Abir, The (originally the Anglo-Belgian Indiarubber Company) .. 56,201 Akula .. $\begin{array}{lllllllll}\text { Albert, Lake } \ldots & \ldots & \ldots & \ldots & \ldots & \ldots & \ldots & \text { I9, } 266\end{array}$

$\begin{array}{llllllllll}\text { Anthropological Society } & \ldots & & \ldots & \ldots & \ldots & \ldots & \ldots & \end{array}$ $\begin{array}{lllllllll}\text { Antwerp } & \ldots & \ldots & \ldots & \ldots & \ldots & \ldots & \ldots & \text { I, } 5,56\end{array}$ Arabs

Aruwimi District

, $39,214,220,224,266$ Aruwimi River

Azande

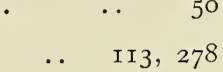

\begin{tabular}{|c|c|c|c|c|c|c|c|c|c|c|c|c|c|c|}
\hline Bagamoya & $\cdots$ & & $\cdots$ & & .. & & $\ldots$ & & .. & & - & & . & I 82 \\
\hline Baiengi & & . & & $\cdots$ & & . & & . & & $\cdots$ & & . & 90, & I43 \\
\hline Bahr-el-Ghaze & $\cdots$ & & . & & $\cdots$ & & . & & $\cdots$ & & . & & 266 & 26 \\
\hline Bakussu Tribe & & . & & . & & . & & .. & & $\cdots$ & I9, & II3, & 250 & 257 \\
\hline Baluba .. & - & & $\cdots$ & & $\cdots$ & & . & & . & & I I3, & 286 & 250 & 25 \\
\hline Baltus, M. & & .. & & .. & & .. & & . & & .. & & 278 & 279, & 28 \\
\hline Bangala Tribe & . & & .. & & $\cdots$ & & . & & 66, & II 3, & I 53, & I64, & I68, & \\
\hline Bango-Bango & ibe & $\cdots$ & & . & & $\cdots$ & & . & & . & & . & & \\
\hline Banana .. & . & & .. & & $\cdots$ & & $\cdots$ & & $\cdots$ & & I 82, & I 83, & I89, & 26 \\
\hline Banza Tribe & & . & & $\cdots$ & & . & & . & & . & & $\cdots$ & II 3, & \\
\hline Bapoto Tribe & . & & . & & . & & . & & . & & . & . & . & \\
\hline Barumbu & & . & & . & & . & & . & & . & & . & & \\
\hline
\end{tabular}

Basoko II, I4, 26, 27, 3 I $, 50,2$ I $_{4}, 2 I_{5}, 220,229,236,269,272,273,278,2 \gamma_{4}$ Batetela Tribe $\quad \ldots \quad \quad \ldots \quad$ I8, I9, 2O, 2I, 48, II $3,284,285,25$ I, 267 Beernaert, M. $\quad \ldots \quad$. $\begin{array}{lllllllll}\text { Belgian Army } & \ldots & \ldots & \ldots & \ldots & \ldots & \ldots & \text { I6 }\end{array}$

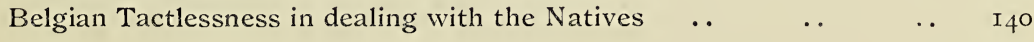
$\begin{array}{llllllllll}\text { Benge } & \ldots & \ldots & \ldots & \ldots & \ldots & \ldots & \ldots & 23 \text { I }\end{array}$

$\begin{array}{llllllllll}\text { Berlin Treaty } & \ldots & & \ldots & \ldots & \ldots & \ldots & \ldots & \ldots & 44\end{array}$ 


\section{INDEX-contimued.}

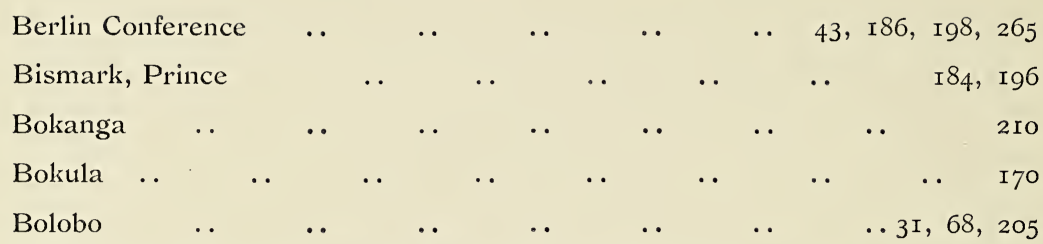

Boma I, 2, 3, 4, II, I2, I9, 22, 64, I67, I82, I83, 202, 203, 2I7, 262, 263, 278

Bomu . $50,5 \mathrm{I}, 54$

$\begin{array}{llllllllll} & \text { "Brabant, The" } & \text {. T } & \ldots & \ldots & \ldots & \ldots & \ldots & \ldots & 32\end{array}$

Braeckman, Lieut., in command of the Mongalla Expedition _. I7O, I7I

\begin{tabular}{|c|}
\hline Brazza, De \\
\hline
\end{tabular}

$\begin{array}{lllllllllll}\text { Brazzaville } & \ldots & \ldots & \ldots & \ldots & \ldots & \ldots & \ldots & 4, \text { I2, I5 }\end{array}$

$\begin{array}{llllllllll}\text { British Government } & \ldots & \ldots & \ldots & \ldots & \ldots & \ldots & \text { 2I7 }\end{array}$

$\begin{array}{lllllllll}\text { Budja Elwa Tribe } & \ldots & & \ldots & \ldots & \ldots & \ldots & \ldots & 90,92\end{array}$

$\begin{array}{llllllllll}\text { Budjala Tribe } & \ldots & \ldots & \ldots & \ldots & \ldots & \ldots & \ldots & \mathrm{I}_{72}\end{array}$

Budja Tribe $72,76,84,86,89,93,97,99$, Iоo, IоI, I02, I04, IIo, II2, II3, II6, II7, I20, I2I, I22, I23, I33, I35, I36, I39, I42, I48, I49, I52 I54, I56, I57, I58, I60, I6I, I64

Buela Tribe

Bula Matari $\quad . \quad \quad \ldots \quad \quad \ldots \quad \quad \ldots \quad 82,85$, II $8,206,257,258,264$

$\begin{array}{lllllllll}\text { Bumba } & \ldots & \ldots & \ldots & \ldots & \ldots & \ldots & 90, \text { I3I, I59, I64 }\end{array}$

$\begin{array}{llllllllll}\text { Burke, Lindsey } & \ldots & \ldots & \ldots & \ldots & \ldots & \ldots & 285,286\end{array}$

$\begin{array}{llllllll}\text { Cannibalism } & \ldots & \ldots & \ldots & \ldots & \ldots & \ldots & 2 \mathrm{I} 2,2 \mathrm{I} 3,2 \mathrm{I} 4\end{array}$

$\begin{array}{lllllllll}\text { Catholic Missionaries . . } & \ldots & \ldots & \ldots & \ldots & \ldots & 36\end{array}$

"Chicotte, La," a Heavy Whip of Hippopotamus Hide, used in flogging the

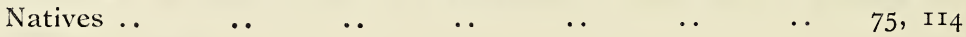

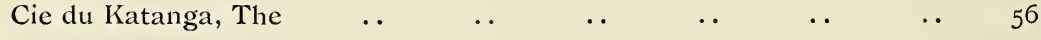

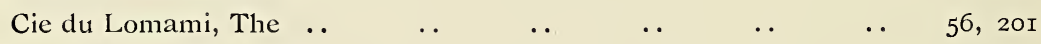

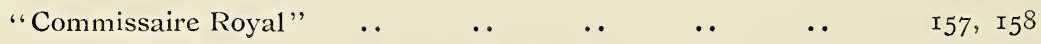

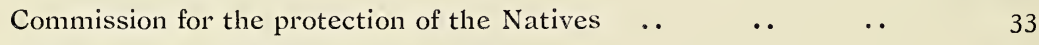

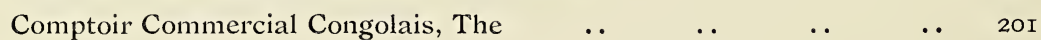

$\begin{array}{lllllllll}\text { Congo Arabs } & \ldots & \ldots & \ldots & \ldots & \ldots & \ldots & \ldots & \text { 19, } 48\end{array}$

$\begin{array}{lllllllllll}\text { Congo Lualaba River } & \ldots & \ldots & \ldots & \ldots & \ldots & \ldots & 50\end{array}$

$\begin{array}{lllllllll}\text { Congo River } & . & \ldots & \ldots & \ldots & \ldots & \ldots & \ldots & 63,24 \mathrm{I}\end{array}$

Costermans, the Belgian Explorer and Colonist $\quad \ldots \quad \ldots \quad \ldots \quad$ ro, 285

$\begin{array}{llllllll}\text { "Coomassie" } & \ldots & \ldots & \ldots & \ldots & \ldots & \ldots & \end{array}$

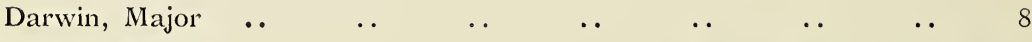

Dhanis, Baron $\quad \ldots \quad \quad \ldots \quad \quad \ldots \quad \ldots 20,175,177$, I80, 250,260 


\section{INDEX-continued.}

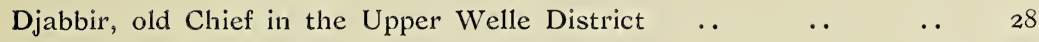

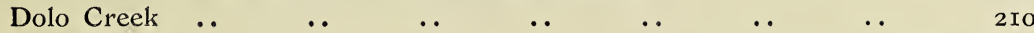

Domain Privé $\quad . . \quad \ldots \quad 45,49,50,52,56,58,199,200,201,25^{8}$

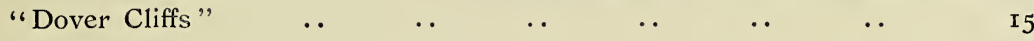

$\begin{array}{llllllllll}\text { Dundu Sana } & . . & \ldots & \ldots & \ldots & \ldots & \ldots & & \ldots & \text { I64 }\end{array}$

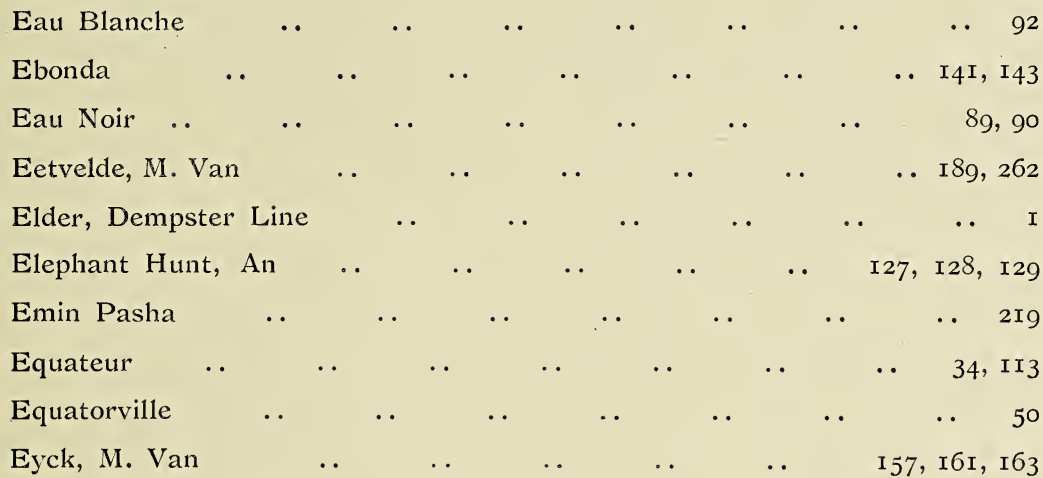

Force Publique $\quad . \quad \quad . . \quad \mathrm{I}_{4}, \mathrm{I} 8,23,30,84,86, \mathrm{I} 08, \mathrm{I} 74, \mathrm{I} 75, \mathrm{I} 77, \mathrm{I} 78,257$

$\begin{array}{lllllllll}\text { French Senegalese } & . & & \ldots & \ldots & \ldots & \ldots & \ldots & 4,9,2 \text { I }\end{array}$

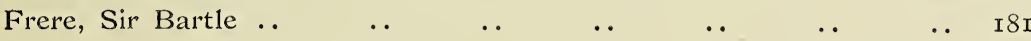

$\begin{array}{llllllll}\text { Gilson, Lieut. .. } & \ldots & \ldots & \ldots & \ldots & \ldots & \ldots & \mathrm{I}_{42}\end{array}$

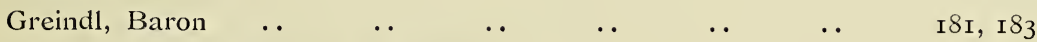

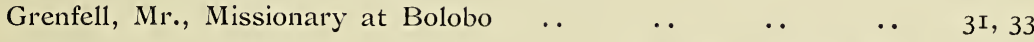

Gombés $\quad . . \quad \quad . . \quad \quad . . \quad \quad \ldots \quad \quad \ldots \quad 89$, Iог, I52, I6I, 269, 270, 27 I

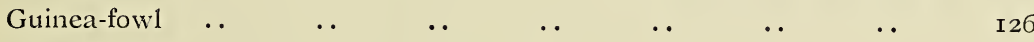

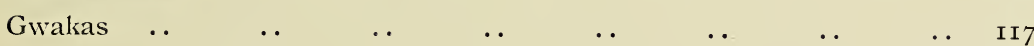

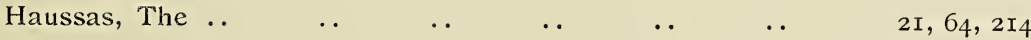

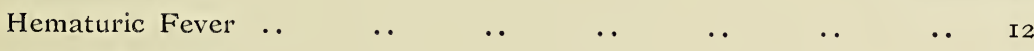

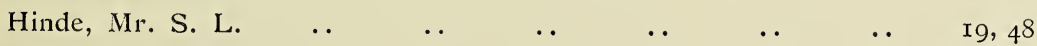

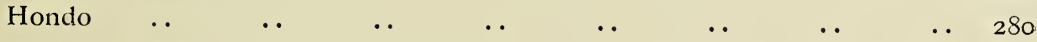

Hottiaux, M. .. $\quad . . \quad \quad . \quad \quad \ldots \quad \quad .278,279,280,28 \mathrm{I}, 283,285$

"Human Meat"

Ignorance and brutal stupidity of the Belgians .. $\quad \ldots \quad$. . $44^{2}$

$\begin{array}{llllllllll}\text { Ikelemba .. } & \ldots & \ldots & \ldots & \ldots & \ldots & \ldots & \ldots & 5 \text { I }\end{array}$ 


\section{INDEX-continued.}

$\begin{array}{lllllllll}\text { Inkissi River } & \ldots & \ldots & \ldots & \ldots & \ldots & \ldots & \ldots & 8\end{array}$

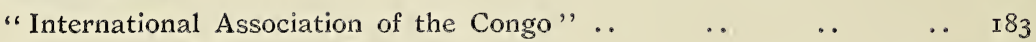

$\begin{array}{llllllllll}\text { Irebu } & \ldots & \ldots & \ldots & \ldots & \ldots & \ldots & \ldots & 24,205\end{array}$

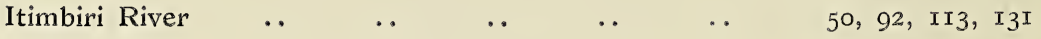

$\begin{array}{llllllllll}\text { Kassai River . . } & \ldots & \ldots & \ldots & \ldots & \ldots & \ldots & & \text { 5I }\end{array}$

$\begin{array}{lllllllll}\text { Kassongo } & \ldots & \ldots & \ldots & \ldots & \ldots & \ldots & 259,284\end{array}$

$\begin{array}{lllllllll}\text { Katanga River } & \ldots & \ldots & \ldots & \ldots & \ldots & \ldots & 50\end{array}$

$\begin{array}{lllllllllll}\text { Kapua } & \ldots & \ldots & \ldots & \ldots & \ldots & \ldots & \ldots & & \end{array}$

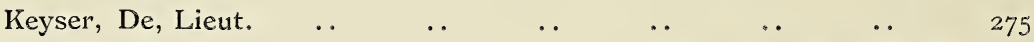

"Kilima" $" . \quad \ldots \quad \quad \ldots \quad \quad \ldots \quad \quad \ldots \quad 226,227,228,229,230,23$ I

$\begin{array}{llllllllll}\text { Kimpasse } & \ldots & \ldots & \ldots & \ldots & \ldots & \ldots & \ldots & 65\end{array}$

$\begin{array}{lllllll}\text { Kinchassa } & \ldots & \ldots & \ldots & \ldots & \ldots & \text { I } 4, I_{5}, I 6,23,69\end{array}$

$\begin{array}{lllllllllll}\text { Kiva, Lake } & \ldots & \ldots & \ldots & \ldots & \ldots & \ldots & \ldots & & & \end{array}$

Kumandungu, A Budja Chief $\quad$.. I27, I30, I3I, I36, I39, I40, I4I

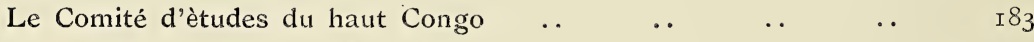

$\begin{array}{lllllllllll}\text { Lagos } & \ldots & \ldots & \ldots & \ldots & \ldots & \ldots & \ldots & \ldots & \text { II } 3\end{array}$

Lantsheere, M. de $\quad \begin{array}{llllllll}\text { M. } & \ldots & \ldots & \ldots & \ldots & \ldots & \ldots & \text { I92 }\end{array}$

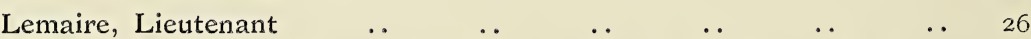

Leopold II., King of the Belgians I6, 43, 5I, 58, 63, I06, I07, I79, I80, I82, I 84, I 86, I 87, I90, I96, I98, 200, $205,263,268$

Leopold II., Lake $\quad \ldots \quad$.

Leopoldville I, 4, 5, 7, Io, II, I2, I4, 23, 32, 63, 64, 65, 66, 68. 69, I78, 210, 257

Leopoldville Mission

. 33

$\begin{array}{llllllllll}\text { Lida } & \ldots & \ldots & \ldots & \ldots & \ldots & \ldots & \ldots & \ldots & \text { I } 7 \mathrm{I}, \mathrm{I} 72\end{array}$

$\begin{array}{llllllllll}\text { Ligassa } & \ldots & \ldots & \ldots & \ldots & \ldots & \ldots & \ldots & 280,282,284\end{array}$

$\begin{array}{lllllllll}\text { Likimi } & \ldots & \ldots & \ldots & \ldots & \ldots & \ldots & \ldots & \text { I45 }\end{array}$

$\begin{array}{lllllllll}\text { Likwangula } & \ldots & \ldots & \ldots & \ldots & \ldots & \ldots & \text { Ir } 3,250\end{array}$

$\begin{array}{llllllllllll}\text { Limputu } & \ldots & \ldots & \ldots & \ldots & \ldots & \ldots & \ldots & & & & \ldots\end{array}$

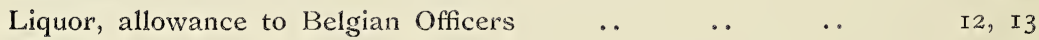

$\begin{array}{lllllllllll}\text { Lisala } & \ldots & \ldots & \ldots & \ldots & \ldots & \ldots & \ldots & & 89\end{array}$

$\begin{array}{lllllllllll}\text { Loango } & \ldots & & \ldots & \ldots & \ldots & \ldots & \ldots & \ldots & \ldots & 4\end{array}$

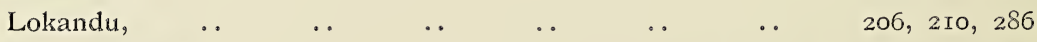

Lomami River _. $\quad \ldots \quad \quad \ldots \quad \quad \ldots \quad 50,250,274,277,278,284$

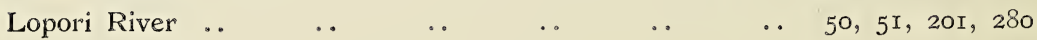

"Lopembe" 


\section{INDEX-continued.}

Lothaire, "Major"

Lower Congo

Luala ..

Lualaba River

Lukolela

Lulubourg

Lufu ..

Lukeli Tribe

Lukenie River

Lukungu .

Lutété, Chief of the Batetelas
$58,72,86,88,92$, I04, II6, II8, II9, I20, I4I, I $57, \mathrm{I}_{5} 8,200$

$$
\begin{aligned}
& \begin{array}{lllll}
\because & & & &
\end{array} \\
& \begin{array}{llll}
\text {. } & \text {. } & \text {. } & 4
\end{array} \\
& \text { I23, 206, 256, } 259 \\
& \text {. } \quad \text {. } \quad 50 \\
& \text {.. } \quad \mathrm{I} 8_{3}, 28_{4} \\
& \begin{array}{lllll} 
& & & & \\
& & & &
\end{array} \\
& \text {. } \quad \text {. } \quad 274 \\
& \text {.. } 50 \\
& \text { 5I, 65, 66, } 266 \\
& \text {.. } 20,260
\end{aligned}
$$

Madjambuli

Malet, Lieutenant ..

9o, 92, 96, 97

Maganzulu Tribe

Malua River

Mandika Garrison

Mangbettou

Manyema District ..

Manyema Tribe

Manyema River

Maringa River . .

Marinel, Le, Lieutenant

Matadi-Leopoldville Railway

Matadi

Mayumba

Methods of Punitive Expeditions

Marchand, Lieut.

$39,4 \mathrm{I}, 42$

.. I23, I32, I33, I35

I 45, I60, I63, I64

84, I04, IIO, II2, II3, II7, I3I

.. 2I7, 2I9, 227, 228

$2,22,257,260$

I9, Iо3, II3

.. $\quad$.

.. 50

.. 5O, 2OI

48,49

.. $\quad$.

I, $5,6,7,9,63,83,266$

Michel, M.

Michaux, Commandant

Mobangi Tribe

Mobeka

Mobongo

Mogandjo

Mogwandi ..

Mombassa District

Mondungu 
INDEX-continued.

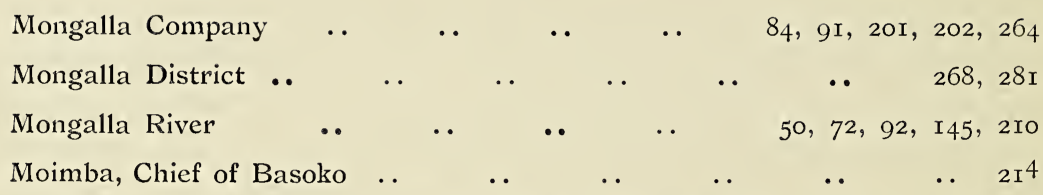

Monjoa .. I25, I34, I39, I4 I, I45, I46, I47, I48, I52, I58, I6r, I62, I64

Moray, a Belgian, indicted for having killed in cold blood a Native Chief $\quad$ I57

$\begin{array}{lllllllllll}\text { Munyumbi } & \ldots & \ldots & \ldots & \ldots & \ldots & \ldots & \ldots & \end{array}$

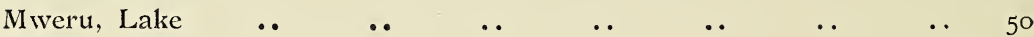

$\begin{array}{lllllllll}\text { Nachtigall Dr. } & \ldots & \ldots & \ldots & \ldots & \ldots & \ldots & \mathrm{r} 8 \mathrm{r}\end{array}$

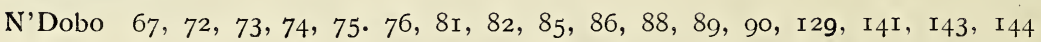
$\mathrm{r}_{4} 6, \mathrm{I}_{49}, \mathrm{I}_{5} 2, \mathrm{I}_{53}, \mathrm{I} 6 \mathrm{I}, \mathrm{I}_{4}, \mathrm{I}_{5}$

$\begin{array}{llllllllll}\text { Nepoko River } & \ldots & \ldots & \ldots & \ldots & \ldots & \ldots & \ldots & 224\end{array}$

$\begin{array}{lllllllll} & \text { N'Giri River.. } & \ldots & \ldots & \ldots & \ldots & \ldots & \ldots & \text { I } 72, \mathrm{r} 73\end{array}$

$\begin{array}{lllllllllll}\text { Niam-Niam } & \ldots & \ldots & \ldots & \ldots & \ldots & \ldots & \ldots & \text { I8 }\end{array}$

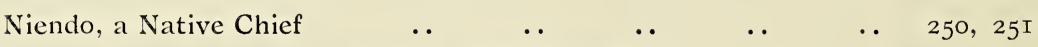

Nieuwe Rotterdam'sche Handels-Vernootschaap $\quad \ldots \quad \ldots \quad \ldots \quad \ldots \quad \ldots \quad 46$

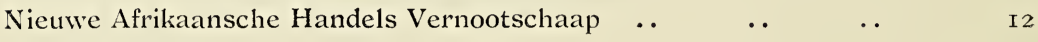

$\begin{array}{llllllllll}\text { North, Colonel } & \ldots & \ldots & \ldots & \ldots & \ldots & \ldots & \ldots & \text { IоI }\end{array}$

$\begin{array}{lllllllll}\text { N'Yangara } & \ldots & \ldots & \ldots & \ldots & \ldots & \ldots & 217,219,228\end{array}$

Nyangwe $\quad . \quad \quad \ldots \quad \quad \ldots \quad \quad \ldots \quad \quad 182,250,256,259,260,284,286$

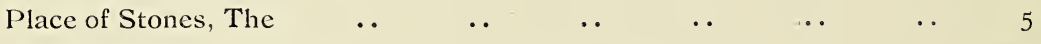

$\begin{array}{lllllllll}\text { Ponthierville } . . & \ldots & \ldots & \ldots & \ldots & \ldots & \ldots & 209\end{array}$

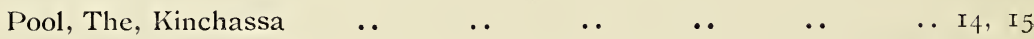

$\begin{array}{lllllll}\text { Province Orientale } & \ldots & \ldots & \ldots & \ldots & \ldots & 79,206,257\end{array}$

$\begin{array}{lllllllll}\text { Putte, M. Van der } & \ldots & \ldots & \ldots & \ldots & \ldots & \ldots & 2 S_{3}\end{array}$

Quatrefages, M. De

$\begin{array}{lllllll}\cdots & \ldots & \ldots & \ldots & \ldots & \ldots & \mathrm{I} \delta \mathrm{I}\end{array}$

Rubber gathering in the Congo

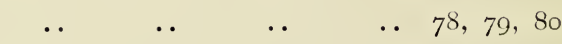

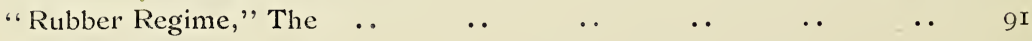

$\begin{array}{llllllll}\text { Rubber Taxes } & \ldots & \ldots & \ldots & \ldots & \ldots & \ldots & 5^{\text {I }}\end{array}$

$\begin{array}{llllllllll}\text { Ruki, River } & \ldots & \ldots & \ldots & \ldots & \ldots & \ldots & \ldots & 5 \text { I }\end{array}$ 


\section{INDEX—continued.}

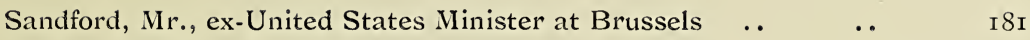

$\begin{array}{llllllllll}\text { Shinkakassa Fort .. } & \ldots & & \ldots & \ldots & \ldots & \ldots & & \ldots & 19,22\end{array}$

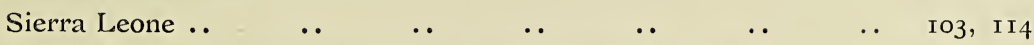

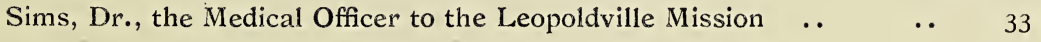

$\begin{array}{lllllllllll}\text { Smelts, Mr. } & \text {. } & \text {. } & \text {. } & \text {. } & \text {. } & \text {. } & \text {. } & \text {. } & & 285\end{array}$

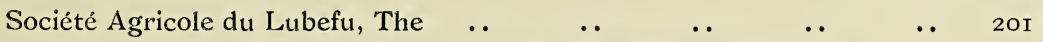

Société Anonyme Belge pour le Commerce du Haut Congo, The .. $\quad{ }_{5}^{8}$

Société Anonyme d'Agriculture et de Plantations au Congo, The $\quad \cdots 56$, 20 I

Société Anversoise du Commerce au Congo $\quad . . \quad \ldots \quad$ 56, 200. 201

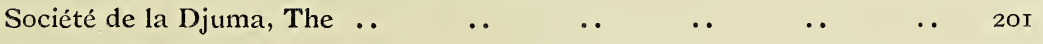

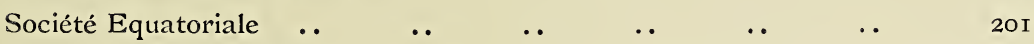

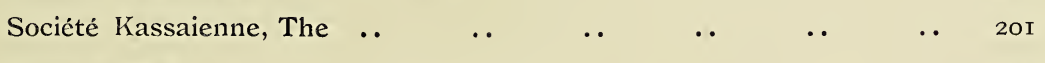

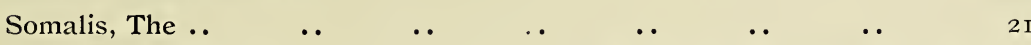

Stanley, Sir H. M. $\quad$.. $\quad . . \quad 5$, Iо, I5, 83, I82, I83, I86, 2 I 4

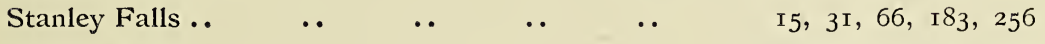

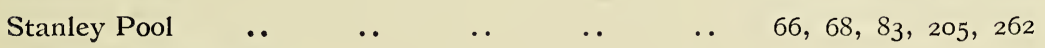

$\begin{array}{llllllll}\text { "Stone Smasher, The .. } & \ldots & \ldots & \ldots & \ldots & \ldots & 5\end{array}$

Stokes, an Englishman, lynched by order of "Major" Lothaire I I9, 263

$\begin{array}{lllllllll}\text { Stranch, Col. .. } & \ldots & \ldots & \ldots & \ldots & \ldots & \ldots & \text { I83 }\end{array}$

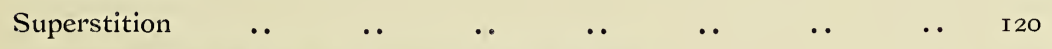

System of Telegraphing by means of Tom-Toms $\quad . . \quad \ldots \quad$ I23, I24

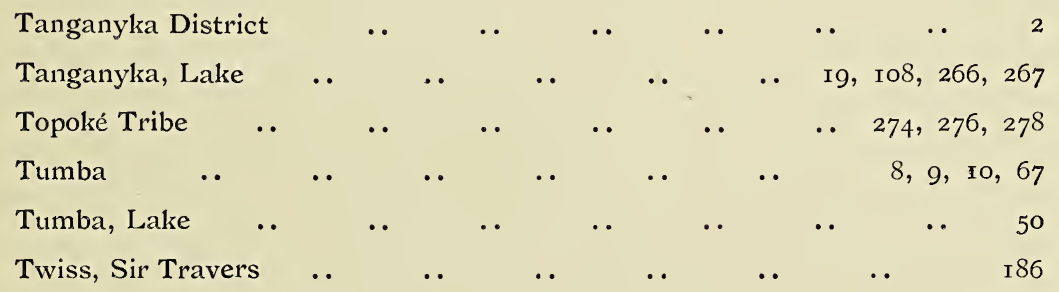

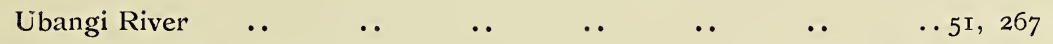

$\begin{array}{lllllllll}\text { Úmangi } & . . & . & \ldots & \ldots & \ldots & \ldots & 84, \text { 1о0, } 205\end{array}$

$\begin{array}{llllllllll}\text { Upper Congo River } & \ldots & & . & & \ldots & \ldots & \ldots & \ldots & 68\end{array}$

Upper Welle .. $\quad . . \quad \quad \ldots \quad \quad \ldots \quad \quad \ldots$ I4, I 8, I9, $24,28,220,226$

$\begin{array}{llllllllll}\text { Urua River } & . & & . & & . & & & & \end{array}$

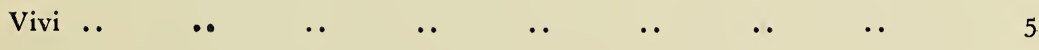

$\begin{array}{llllllllll}\text { Wabudjwa } & . . & . & \ldots & & \ldots & & & & \end{array}$ 


\section{INDEX-continued.}

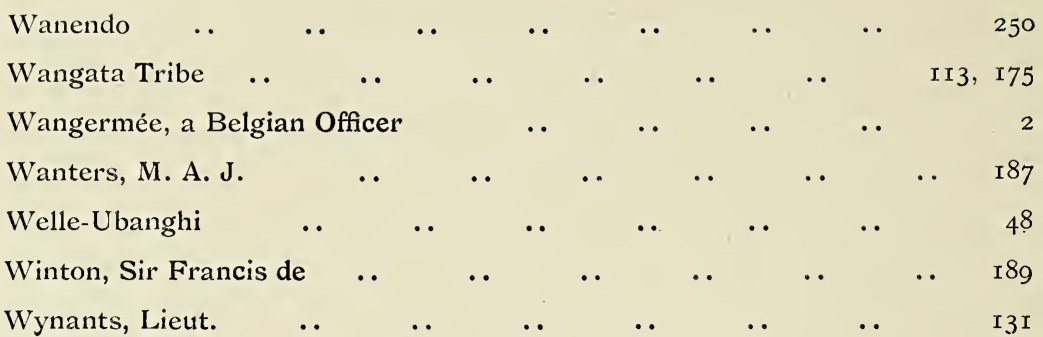

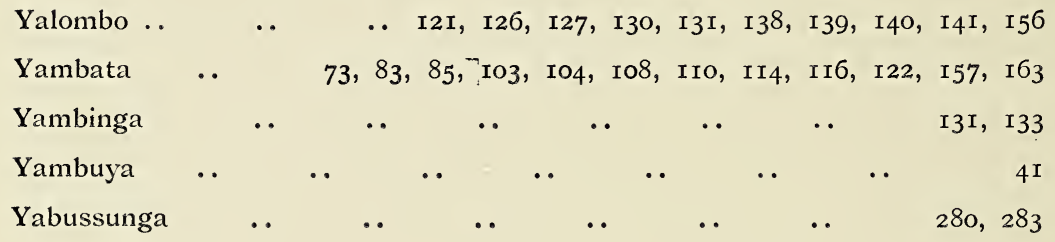

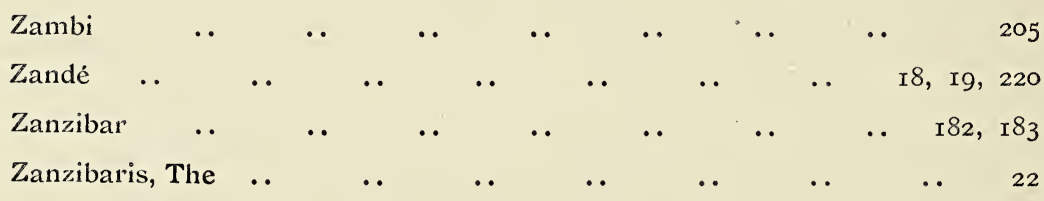




\section{A SELECTION OF BOOKS}

RECENTLY • ISSUED • BY

Messrs. R. A. EVERETT \& CO.,

LTD . 42. ESSEX STREET.

STRAND. . LONDON. . W.C. . .

Telegrams \& Cables :

"ACCOUTRED, LONDON."
4719 GERRARD. 


\section{Mr. NICHOLASS EVERITT'S New Edition of SHOTS FROM A LAWYER'S GUN,}

Profusely Illustrated, Demy 8vo., Cloth Gilt, 7s. 6d., net.

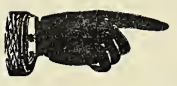

THE success of the First Edition has led the Author to thoroughly revise and enlarge this important and valuable work-the only illustrated and thoroughly up-to-date book on the Game Laws-by the addition of (1) A Table of Statutes; (2) A List of Cases ; (3) An Index; (4) and new chapters on a variety of additional subjects.

Many of the characters, exciting episodes, and Poaching reminiscences in the First Edition, which caused so much comment and amusement have been illustrated by a well-known artist, and it is hoped the legal as well as the lay reader will appreciate for the first time that law can be made amusing as well as interesting, and at the same time sound and reliable.

\section{Shots ${ }_{A A}^{\text {From }}$ Lawyer's Gun}

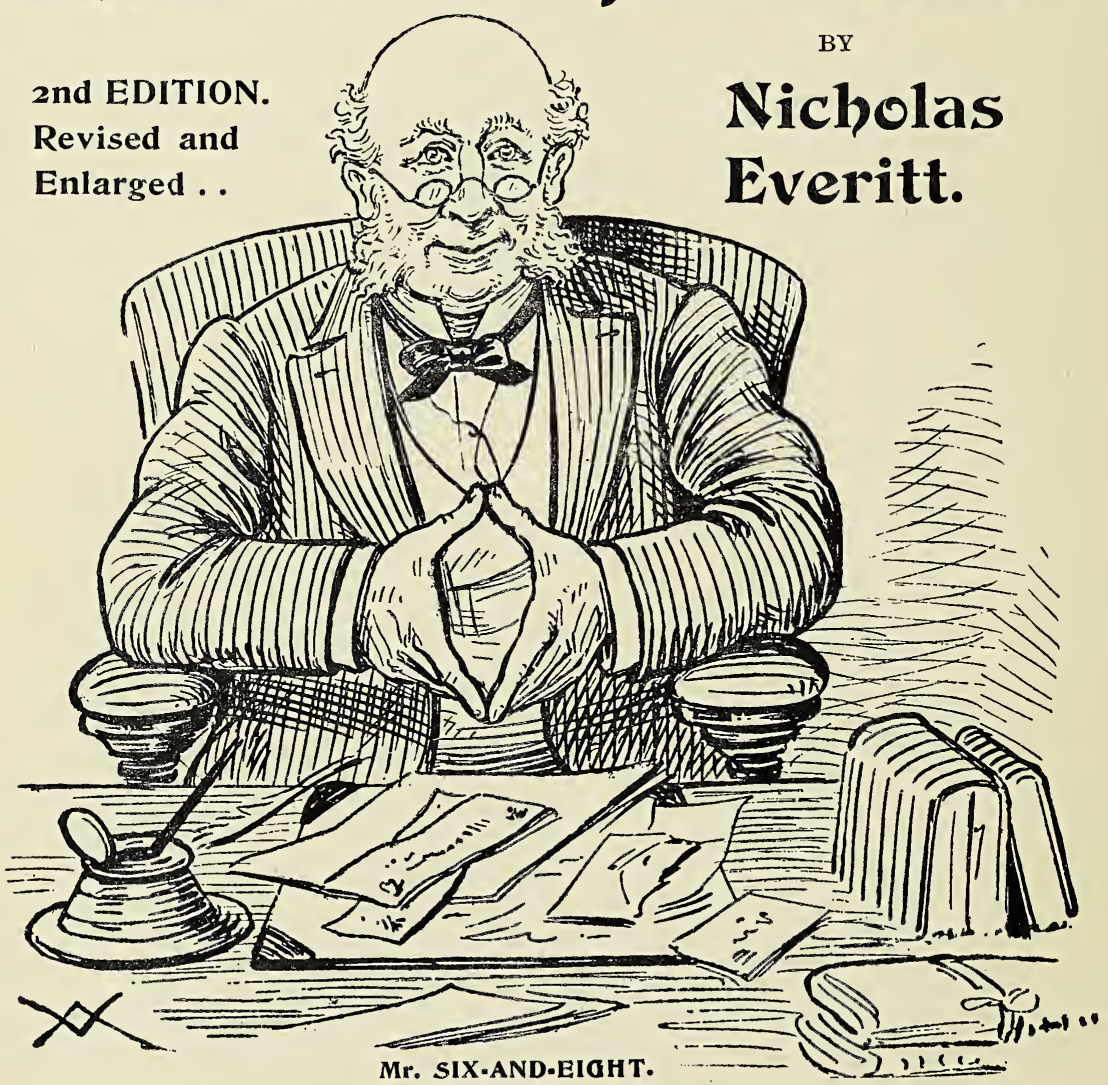

"Nothing is certain in Law except the expense."

London: R. A. EVERETT \& C0., 42, Essex Street, Strand, W. 


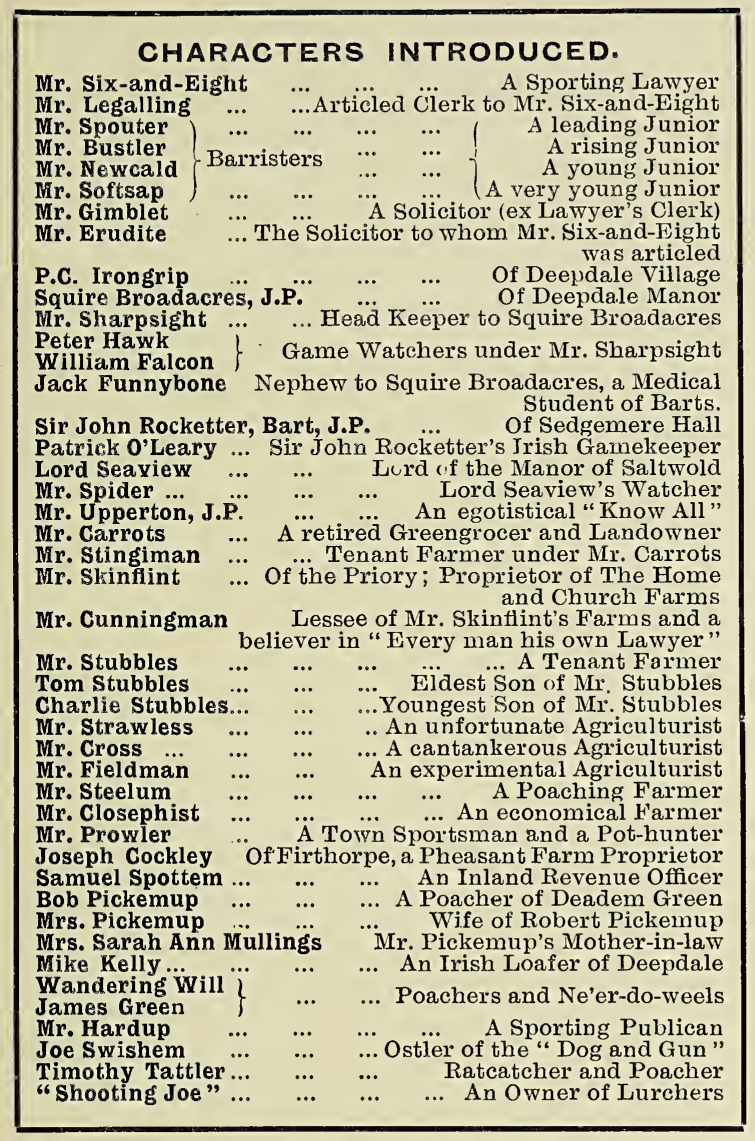

\section{A few Press 0pinions}

\section{On the First Edition.}

We have read this book from end to end, with great pleasure. Mr. Everitt's style is well calculated to lure any sportsman into reading his lectures to the end. Even the professional poacher may be grateful to the writer. The pages are full of chatty and amusing anecdotes. We may disinterestedly commend $\mathrm{Mr}$. Everitt's book, from which readers will obtain both sound instruction and more amusement than they would find in the average sensation novel.-The Field.

Mr. Everitt has made many a good shot in his book, which mixes the useful with the agreeable. Mr. Everitt is a safe guide. $\mathrm{He}$ knows his subject uncommonly well.-Athenceum.

I have to congratulate Mr. Nicholas Everitt and his publishers on the production of an exceedingly clever little volume, which gives a free and easy exposition of the Game Laws that can be understood by the man in the street. The book is excellent. It is a book for every sportsman to buy and read.-The Traveller.

This book is a veritable triumph.-The Gamekeeper.

We c smmend Mr. Everitt's book to all who have to do with dog or gun. The book is nicely printed and bound, the droll design on the cover thereof being highly appropriate to the contents.-Norfolk Daily Standard.

The Author fortifies his opinions at all points with plentiful references, and a professional brother has been unable to find any flaws in his legal lore. The public can congratulate the author on his most successful attempt to give a clear and ucid exposition of these mysteries put in such a way as to be within the comprehension of all. It is a volume that will be of the utmost value to the sporting man and his satellites, and perchance to his enemy, the poacher.-Aberdeen Free Press.

The book is the work of a lawyer who hesitates not to combine his capacity for entertaining with amusing tales lucid exposition of laws to anyone interested in the points with which he deals, whether he be the Squire of the Hall, the gamekeeper, or the poacher.-The Scotsman.

All the various points arising with reference to the subject are dealt with in a light and easy style, and in its way the book, we think, will serve a useful purpose. -The Law Times.

This book is full of curious and entertaining matter, and we commend it to all gamekeepers, game-preservers, game-dealers, game-shooters, magistrates, and poachers who can read.-The Speaker.

\section{London: R. A. EVERETT \& Co., 42, Essex Street, Strand, W.C.}


BY THE SAME AUTHOR.

THE MOST COMPLETE AND EXHAUSTIVE WORK ON GENERAL SPORT YET PUBLISHED.

Third Edition, Cloth Gilt extra, 12s. 6d. net.

\section{BROADLAND SPORT}

\section{Written and Illustrated by NICHOLAS EVERITT.}

Author of "Shots from a Lawyer's Gun," \&c.

\section{Illustrations. $400 \mathrm{pp}$.}

Also an Edition de Luxe, bound in Half-Vellum, with numerous Photogravure Plates, beautifully printed on special art paper and limited to 100 copies, handsomely bound in Half-Vellum Gilt top and silk marker, each numbered and signed by the Author, price ¿2 2s. net; only a few copies left for sale.

LEADING CONTENTS.-Eels and Eel Bobbing; Decoys: and How to Use Them; Wild Fowling at Sea; Punt Gunning; Curres and Short-Winged Fowl; Wildfowling Costume; Shore Shooting; Flighting; Pike and Coarse Fishing; Otter Hunting; Marshland Shooting; Swamp Shooting; Yachts and Yachting from 1800 to 1900 , \&c.

\section{A FEW PRESS OPINIONS.}

"In acquaintance with the details of all the forms of sport presented by the district of the Broads, the author of 'Shot's from a Lawyer's Gun ' can hardly be rivalled. An interesting chapter is devoted to the management of 'decoys,' by which is meant the exhibition of either living or imitation ducks to attract wild birds within reach of the sportsman's ambush; also on approaching birds by the aid of a canvas body representing a horse or an ass, the illustrations of this being very amusing. In fact, all the productions of Mr. Everitt's pencil show considerable power, and some of the vignettes are beautiful. On the whole the book is pleasantly written, and the account of yachting on the Broads, with illustrations of the competitors in the regattas, is admirable. The index also leaves nothing to be desired."-Athencum.

"We know of no work, old or new, which fulfils its own purpose so thoroughly. It is a book which appeals primarily to the sportsman, but no one who loves the Broads merely from an artistic point of view can fail to find interest on every page. A volume crammed with accurate information and delightful anecdote."-Times.

By the same Author.

TO BE SHORTLY PUBLISHED.

\section{SPORT WITHOUT WORDS}

A series of comic and caricature Sketches, depicting various branches of sport, conducted in a manner perhaps too curious for letterpress description.

London: R. A. EYERETT \& C0., 42, Essex Street, Strand, W.C. 


\section{RECENT BOOKS ON SPORT.}

In Boards, Illustrated by J. Sturgess, 2s. Also in Cloth, 2s. 6d.

Sporting Sketches, by Nat Gould.

A Race-course Tragedy, by Nat Gould.

Warned Off, by Nat Gould.

Life's Webb, by Nat Gould.

Settling Day, by Nat Gould.

King of the Ranges, by Nat Gould.

In Royal Colours, by Nat Gould.

A Racing Sinner, by Nat Gould.

Broken Down, by Nat Gould.

The Silken Rein, by Nat Gould.
The Three Wagers, by Nat Gould.

Raymond's Ride, by Nat Gould.

The Viking Strain, by A. G. Hales.

Outridden, by Fox Russell.

A Judas of To-day, by Fox Russell.

Tricked, by Fox Russell.

Snooker's Racing Adventures, by "G.G." (H. G. Harper)

"On the Grass," by "G.G." (H.G.Harper)

Romances of the Road, by 'Thormanby.'

\section{Everett's SIXPENNY Novels, 1903.}

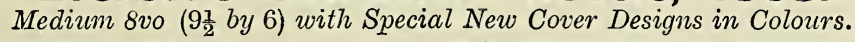

Tom Ossington's Ghost,

by Richard Marsh.

The Woman with One Hand, by Richard Marsh.

A Woman's Story, by Florence Warden. The House by the Lock, by Mrs. C. N. Williamson.

Kate Coyentry, by G.J. Whyte-Melville. Digby Grand, by G. J. Whyte-Melville. General Bounce,

The Interpreter, by G. J. Whyte-Melville. Mystery; His Last Chance; Chased by Fire, 3 complete stories in one vol., by Nat Gould.

The Story of Phil Enderby, by Adeline Sergeant.
The Noble Art ; or, Boxers and their Battles, by "Thormanby."

The West End, by Percy White.

Mr. Blake of Newmarket, by E. H. Cooper.

Snooker's Racing Adyentures, by "G G." (H. G. Harper). The Adxentures of Captain Mounsell, by W. Wilmott Dixon.

The 2nd Series of the Adyentures of Captain Mounsell, by W. WilmottDixon. By Order of the Cross, by John Duos. For Life, by Major Arthur Griffiths. Outridden, by Fox Russell.

The Fate of Captain Petton, by "Weatherby Chesney."

A Good Thing, by "Larry Lynx." Racing, by W. C. A. Blew, M.A.

\section{BOOKS ON HORSES.}

The Yeterinary Manual (for Horse Owners). 2nd Edition, Revised. By Frank T. BARTon, M.R.C.V.S. With about 60 Illustrations. Crown 8vo, 10s. 6d. net.

The Groom's Guide; His Duties, and How to Perform Them. By Frank T. Barton, M.R.C.V.S. Cloth, 2s. net.

How to Choose a Horse; or, Selection before Purchase. By Frank T. Barton, M.R.C.V.S. Cloth. 2s. net.

The Horse: from Birth to Old Age. 2nd Edition, Revised. By S. Buckman-Linard. Fully Illustrated. Crown 8vo, cloth, 3s. 6d.

War Horses : Past, Present, and Future; or, Life among the Remounts in South Africa. By Sydney Galvayne, Hon. Lieut. Remount Corps. Cloth, 2s. 6d.

Dopes : A Criticism of American Arts and English efforts on the "Doping" of Racehorses. By Nathaniel Gubbins (Capt. E. Spencer). Sewed, 2s. 6d.

\section{MISCELLANEOUS BOOKS.}

Sharpshooting for Sport and War. By W. W. Greener. 2nd Edition. Completing 20th Thousand. 200 pp., 100 Illustrations. Sewed, 1s. Cloth, 1s. 6d. net.

Full Cry. By Fred Cotmon. With a Frontispiece in colours and other full-page Illustrations by Harington Bird. 4to, half leather, gilt top (limited to 350 copies), \&1 1s. net.

Cue Tips. Hints on Billiards for 100 Up-pers and Owners of Bijou Tables. By Wm. Mrtchell (B.A. Champion, 1892-7). Edited by F. M. Hotine. Illustrated with 61 Diagrams. Fcap. 8vo, 134 pp., 6d. net.

Thomas Assheton Smith; or, the Reminiscenses of a Famous Fox Hunter. By Sir J. E. EARdLey-Wilmot, Bart. A New Edition with an Introduction by Sir Herbert Maxwell, M.P. Illustrated with numerous Engravings. Cloth gilt, 6 s.

Sporting Sketches. By Nat Gould. Illustrated by Harington Bird. Cloth gilt, $6 \mathrm{~s}$.

The Noble Art: Boxers and their Battles: Anecdotal Sketches and Personal Recollections of Famous Pugilists. By "Thormanby." Illustrated from scarce Portraits. Cloth extra, 6s.

Complete Catalogue Post Free on Application.

London : R. A. EVERETT \& C0., 42, Essex Street, Strand, W. 
THE MOST COMPLETE AND EXHAUSTIVE WORK ON GENERAL SPORT YET PUBLISHED.

Third Edition (Cloth Gilt extra) r2s. 6d. nett.

\section{BROADLAND SPORT.}

Written and Illustrated by NICHOLAS EVERITT.

Author of "Shots from a Lawyer's Gun," \&c.

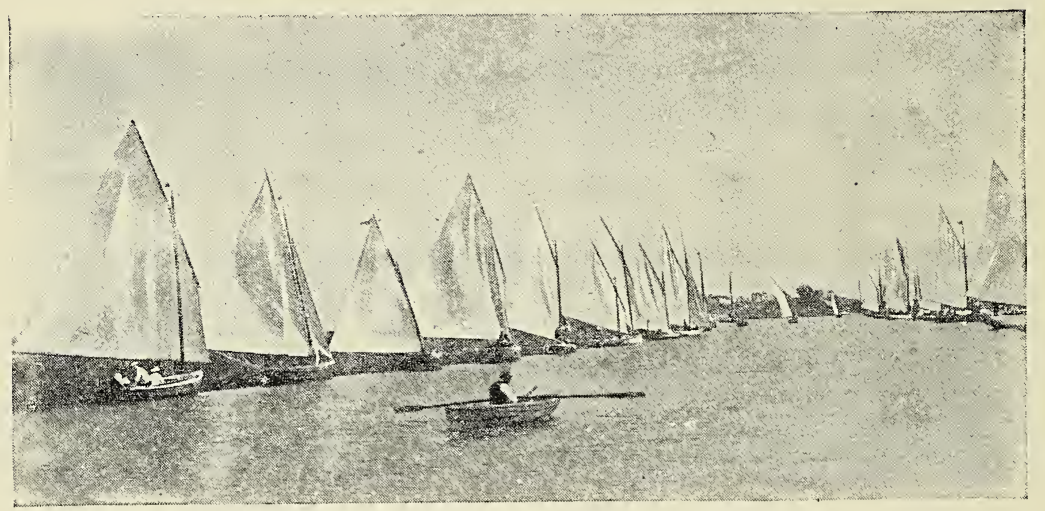

Also an Edition de Luxe, bound in Half-vellum, with numerous Photogravure Plates, beautifully printed on special art paper, and limited to 100 copies, handsomely bound in Half-Vellum, gilt top and silk marker, each numbered and signed by the Author, price $\boldsymbol{f 2}_{2} 2$ s. net; only a few copies left for sale.
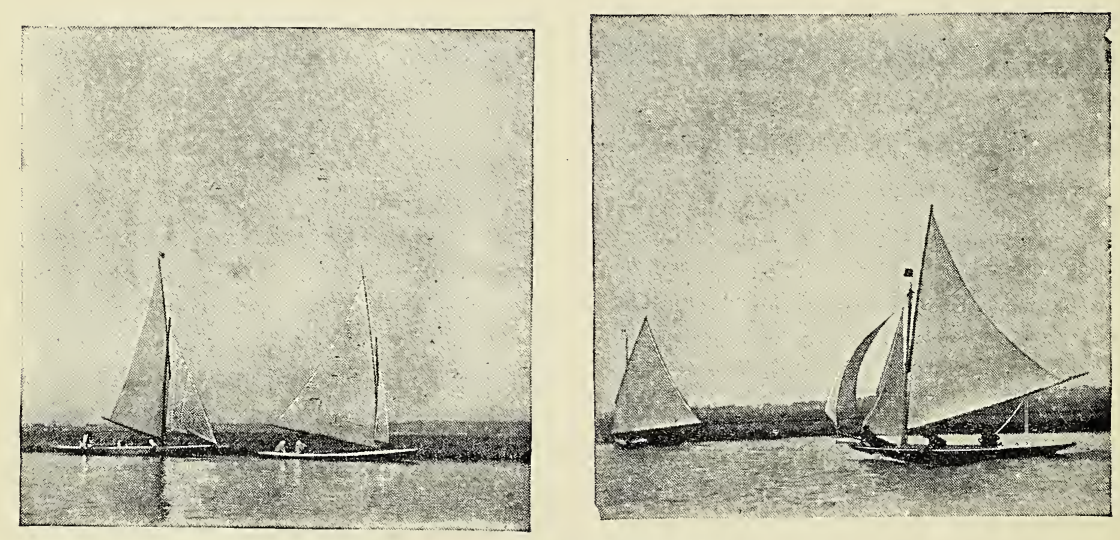

\section{LEADING CONTENTS.}

Eels and Eel Bobbing; Decoys: and How to Use Them; Wild Fowling at Sea ; Punt Gunning; Curres and Short-Winged Fowl; Wildfowling Costume; Shove Shooting; Flighting. Hickling District; Horsey District; The Waveney Valley;

The Yare Valley; Yachts and Yachting from 1800 to 1900, \&c.

"We know of no work, old or new, which fulfils it own purpose so thoroughly. It is a book which appeals primarily to the sportsman, but no one who loves the Broads merely from an artistic point of view can fail to find interest on every page. A volume crammed with accurate information and delightful anecdote."-Times. 
A Copy of this Book has been graciously accepted by His Majesty the King.
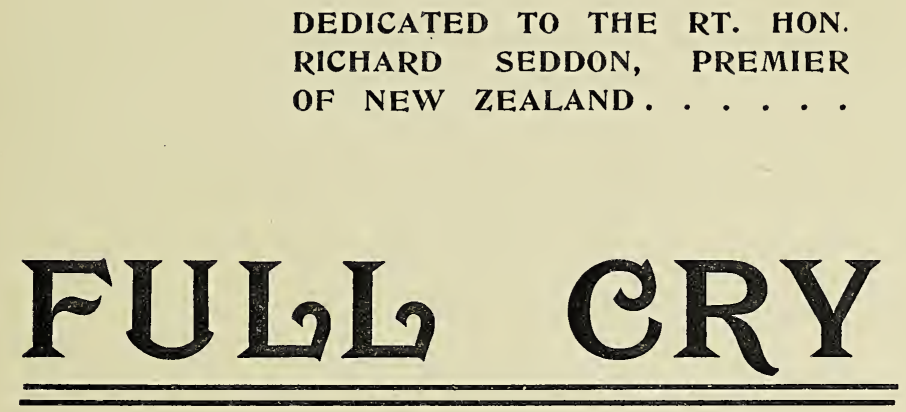

(A Hunting Novel)

\title{
BY FRED COTTON.
}

\author{
WITH FRONTISPIECE IN COLOURS AND \\ OTHER FULL-PAGE ILLUSTRATIONS \\ BY HARINGTON BIRD.
}

4to. Half-leather, gilt top (limited to 350 copies), \&1 : 1 : 0 net.

\section{PRESS OPINIONS.}

"A splendid hunting novel."-Daily News.

" 'Full Cry' gives an insight into the sporting proclivities of our Colonial brethren, and is very handsomely got up."-Pall Mall Gazette.

"A manly and cheery spirit pervades the book, and young people and old do their best to enamour the reader with New Zealand and the New Zealanders. The Volume contains a number of admirable illustrations by Harington Bird."-Scotsman. 


\title{
EVERETT'S NEW SIX SHILLING WORKS
}

\author{
By Popular Authors. Crown 8vo. Cloth Extra,
}

\section{Richard Brice: Adventurer.}

A thrilling and origin al Novel of Adventure in out of the way parts of the world.

By CHARLES JUNOR, Author of "Dead Men's Tales," \&c.

"And so we are in this case doubly glad to feel that we can bestow our meed of praise on Mr. Junor's last sheaf of tales. Fresh, bright, and lively stories of Adventure they are."-Pall Mall Gazette.

\section{The Daughters of Job.}

By “ DARLEY DALE,” Author of “The Village Blacksmith,” \&c.

"They were the Rector's daughters, Jemima, Kezia, and Kerenhappuen, all beautiful, and all bent on going cut into the world. Their respective careers as a lady journalist, a secretary, and cook resolve themselves, needless to say, into love stories readable enough."--Times.

\section{The Man who Died.}

By G. B. BURGIN, Author of "The Cattle Boat," "The Goddess of Gray's Inn," \&c.

\section{The Viking Strain. A realistic Novel.}

By A. G. HALES, War Correspondent, Author of " Campaign Pictures," "Camp Fire Sketches," \&c. Illustrated by Stanley L. Wood.

We should like best to see Mr. Hales make use of his experiences of hard and active life in the new countries of the world, and, if he pleases, of the healthy open air sports of the Old Country. But even as it is, there is so much breezy good humour in 'The Viking Strain' and the story, in spite of much that is disagreeable, is so well constructed that there is a good deal of pleasure to be derived from its perusal.Daily News.

\section{Thomas Assheton Smith; or, The Reminiscences of a Famous}

By Sir J. E. EARDLEY=WILMOT, Bart.

A New Edition with an introduction by Sir Herbert Maxwell, M.P. Illustrated with numerous Engravings.

"Sent out by Messrs. Everett \& Co.. London, with a portrait and a charmingly written introduction from the pen of Sir Herbert Maxwell, the book should secure a new lease of popularity among lovers of sport and sportsmen."-Scotsman.

\section{Sporting Sketches. By NAT GOULD.}

Recollections and reflections on a variety of subjects connected with Sport, Horses, and Horsemen never before published.

Large crown 8vo, handsomely bound, cloth gilt. Illustrated by HARINGTON BIRD,

\section{Boxers and their Battles:}

Anecdotal Sketches and Personal Recollections of Famous Pugilists.

By “"THORMANBY," Author of " Kings of the Hunting Field," "Kings of the Turf," \&c.

Illustrated from scarce Portraits.

"Lovers of 'The Noble Art' will derive considerable pleasure from a perusal of this work." -Daily Telegraph. 


\title{
EVERETT'S NEW THREE SHILLING \& SIXPENNY NOVELS
}

\author{
By Popular Authors. Crown 8vo. Cloth Extra.
}

A Roumanian Vendetta.

By "CARMEN SYLVA" (Queen of Roumania).

A Son of Mars, By MAJOR ARTHUR GRIFFITHS.

A new and powerful Military Novel.

"A brisk military tale of Herbert Larkin's life as a private soldier, officer, and at last, in rightful possession of his true name, as Sir Herbert Farrington, Bart."-Times.

The Gentlemen from Goodwood. A New Sporting Novel. By EDWARD H. COOPER, Author of "Mr. Blake of Newmarket," \&c.

A Sportswoman's Love Letters. 4th Edition.

By FOX RUSSELL, Author of "Colonel Botcherby, M.F.H,"

The Strange Adventures of a Magistrate.

By T. R. THRELFALL, J.P. Author of "The Sword of Allah," \&c.

The Woman with One Hand. By RICHARD MARsh.

Tom Ossington's Ghost. By RICHARD MARSH.

The Extraordinary Islanders. By ASTON FORREST.

A Frontier Officer. A Tale of the Punjaub.

By H. CALDWELL LIPSETT, Author of "Lord Curzon in India," \&c.

The Ghost. By Mrs. CAMPBell PRAED.

My Japanese Wife. By CLIVE holland.

A New and Revised Edition with Coloured Illustrations.

A Sporting Adventurer.

By FOX RUSSELL, Anthor of "Outridden," \&c.

In Royal Colours. By NAT GOULD.

A Story of the Coronation Derby.

The King's Yard, A Story of Portsmouth Dockyard.

By WALTER JEFFERY, Author of "A Century of Our Sea Story," \&c. 


\title{
The "Dash \& Daping" Library.
}

EDITED BY

\section{A. H. MILES.}

Editor of the "A1 RECITERS," the "52 SERIES," etc., etc.

Crown 8vo, with Illustrations, well printed from clear type on good paper, and handsomely bound in cloth gilt, price $2 / 6$ each volume.

\section{The Merry Middies}

\section{of the Enchantress.}

And other Stories of Coastguard and Smuggler.

$\mathrm{BY}$

\author{
Lieut. CHARLES BRAND, R.N., and other Writers.
}

"Some of the stories in this book have been evidently written for boys under the mistaken apprehension that boys can only be appealed to by what is silly and vulgar. Some others are dull and tedious, others are tame attempts to recount what ought to have been stirring adventures of the coast blockade service in the old smuggling days. A few of the better yarns are those dealing with the superstitions of sailors and smugglers."-Bitish Weekly.

\section{Captured by the Navajos Indians.}

And other Stories of Captivity and Escape.

BY

Capt. CURTIS, U.S.A., and other Writers.

"This book contains a series of real adventures in various parts of the world, obtained from naval records. The experiences with the Indians are told with a graphic pen by Chas. Curtis, an American Captain, and by boys the thrilling tale will be highly appreciated. Equally exciting is the capture in China of a party of British seamen, the hardships they endured, and their ultimate escape. Adventures with the Arabs and the Russian Cossacks are also recounted. The book will make a suitable Christmas gift."-Scotsman. 


\section{The "Dash \& Daring” Library}

Continued.

\section{"A Homely Heroine."}

And other Adventurous Stories

BY

FRANCIS GERARD, F. R. STOCKTON, Mrs. CRAIK, and other Writers.

"No better selection could possibly have been made. The stories are not only healthy in tone but brimful of interest from the first page to the last."-Ladies' Field.

Uniform with the above. Cloth gilt, extra, 3/6.

\section{The Story of Stories for Children.}

Translated from the Neapolitan by J. E. TAYLOR.

With Six Illustrations by George Cruikshank. A Reprint of the Scarce Original Edition.

"A translation by J. E. Taylor of Giambattiste Basile's Fairy Tales which will be eagerly read by the children. The wonderful doings of the little people of fairyland are rehearsed in an entrancing manner, both amusing and instructive to the young mind. The bnok is beautifully illustrated, the pictures bearing a look of quaintness which belongs only to the elfin world."-Dundee Courier.

\section{A Scourge of the Sea.}

BY

HERBERT COMPTON.

Author of "The Inimitable Mrs. Massingham," \&c.

With Full-page Illustrations by A. H. FulLwood.

\section{Barcali, The Mutineer;}

A Tale of the Great Pacific.

BY

C. DUDLEY LAMPEN.

Illustrated by H. Piffard. 
"NAT GOULD is the Hawley Smart of Australia."-Vide Press.

\section{SPORTING NOVELS}

\section{By the Most Popular Autbors.}

In Boards, Illustrated by J. Sturgess, 2s. ; also in Cloth, 2s. 6 d.

Sporting Sketches.

A Racecourse Tragedy.

Warned Off.

Life's Web.

Settling Day.

King of the Ranges.

In Royal Colours.

A Racing Sinner.

Broken Down.

The Silken Rein.

The Three Wagers.

Raymond's Ride.

The Viking Strain.

Outridden.

A Judas of To-day.

Tricked.

Snooker's Racing Adventures. By “G.G.” (H. G. Harper)

"On the Grass."

Romances of the Road.
By Nat Gould

By Nat Gould

By Nat Gould

By Nat Gould

By Nat Gould

By Nat Gould

By Nat Gould

By Nat Gould

By Nat Gould

By Nat Gould

By Nat Gould

By Nat Gould

By A. G. Hales

By Fox Russell

By Fox Russell

By Fox Russelu

By “G.G.” (H. G. Harper)

By "Thormanby" 


\section{EVERETT'S SIXPENNY NOVELS, 1903.}

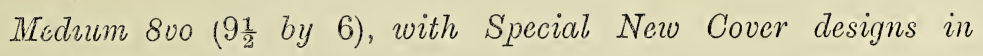
Colours.

Tom Ossington's Ghost.

BY RICHARD MARSH

The Woman with One Hand.

BY RICHARD MARSH

A Woman's Story.

The House by the Lock.

BY FLORENCE WARDEN

Kate Coventry.

Digby Grand.

General Bounce.

The Interpreter.

Sporting Sketches.

By Mrs. C. N. WILLIAMSON

By G. J. WHYTE-MELVILLE

By G. J. WHYTE-MELVILLE

By G. J. WHYTE-MELVILLE

By G. J. WHYTE-MELVILLE

A Racecourse Tragedy. BY NAT GOULD

The Story of Phil Enderby. By ADELINE SERGEANT

The West End.

BY PERCY WHITE

Author of "The Grip of the Bookmaker," \&c.

Mr. Blake of Newmarket.

By E. H. COOPER

The Adventures of Captain Mounsell

By W. WILMOTT DIXON

By Order of the Cross.

By JOHN DUOS

Powerful and Original Detective Stories.

Title not Fixed. By "LARRY LYNX"

(Sporting Editor of The People.)

A New and Original Sporting Novel.

Racing.

By W. C. A. BLEW, M.A.

An entirely new and novel work on Billiards for beginners and moderate players.

\section{Fcap. 8vo, 134 pp. 6d. net.}

Cue Tips. By Wm. MITCHELL

(B.A. Champion, 1892-97.)

Hints on Billiards or 100 Up-pers and owners of Bijou Tables. Edited by F. M. Hotre. Illustrated with 61 Diagrams. 


\section{EVERETT'S SIXPENNY LIBRARY.}

Medium 8xo, ( $9 \frac{1}{2}$ by 6 ) with Special New Cover designs in Colours.

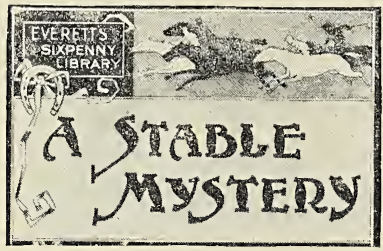

A Stable Mystery;

His Last Chance; and

Chased by Fire.

(3 Complete Stories in one Vol.)

By NAT GOULD.
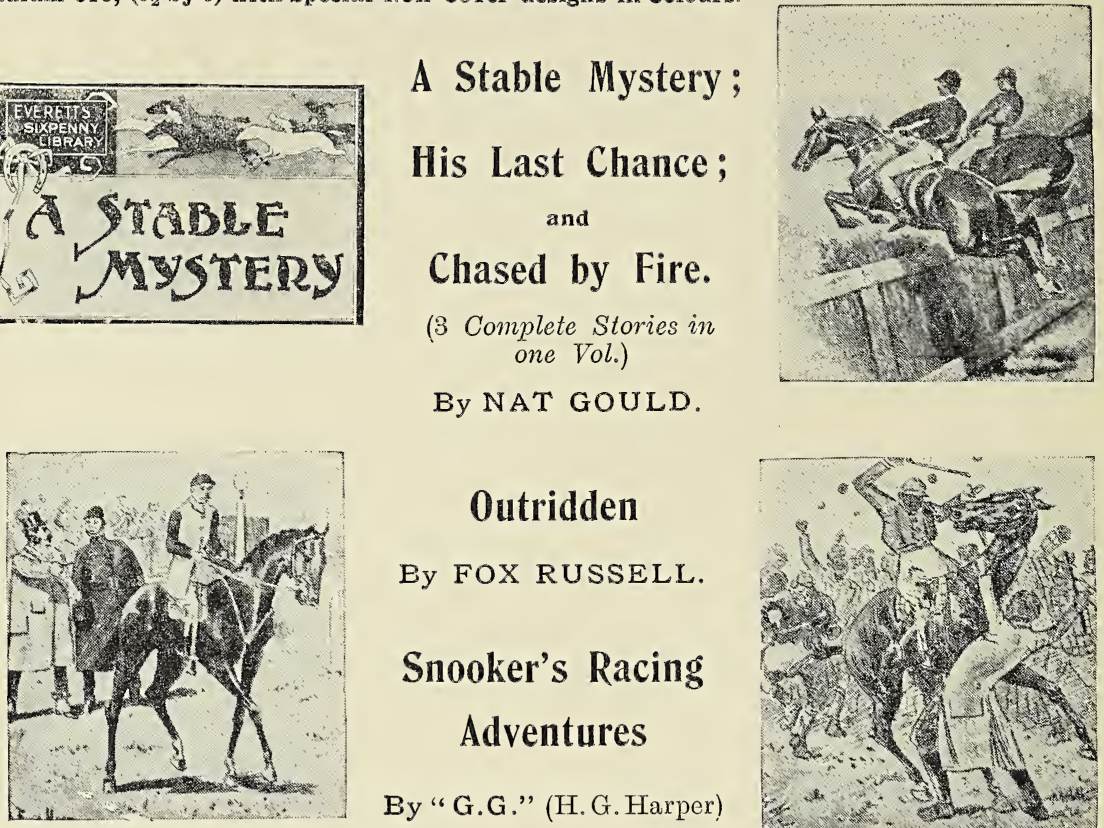

\section{Outridden}

By FOX RUSSELL.

\section{Snooker's Racing}

Adventures

By "G.G." (H. G. Harper)

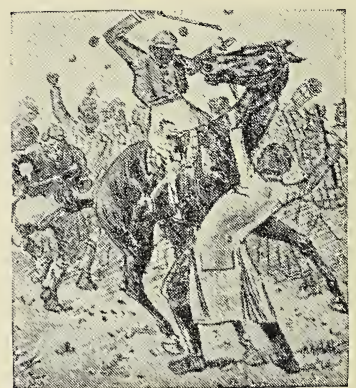

The Noble Art; or,

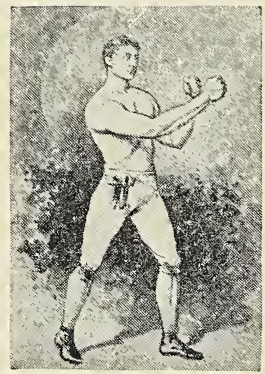
Boxers and their Battles

By “'THORMANBY."

\section{For Life}

A New and Original Novel.

BY MAJOR ARTHUR. GRIFFITHS.

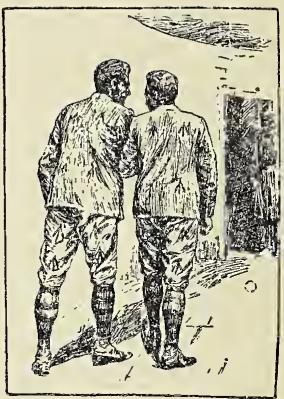

The SECOND SERIES of

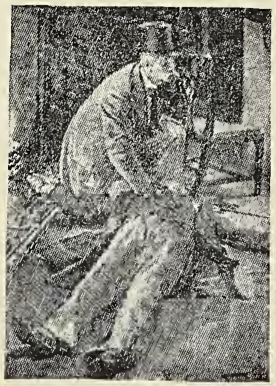
The Adventures of Captain Mounsell By W. WILMOT'T DIXON.

\section{The Fate of} Captain Petton

By " WEATHERBY CHESNEY."

Author of "John Topp, Pirate," Ec.

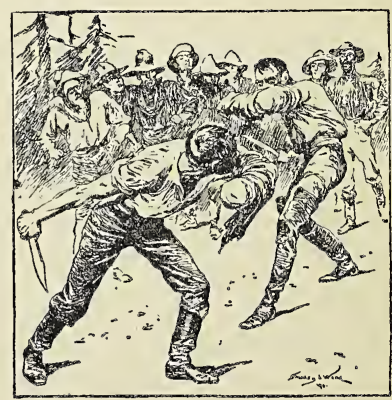




\section{BOOKS ON HORSES.}

The most recent and $u p=$ to=date work on the Horse.

2nd Edition, Revised.

\section{The Veterinary Manual}

\section{For Horse Owners.}

\section{By FRANK T. BARTON, M.R.C.V.S.}

With about 60 Illustrations from Original Drawings, Crown 8vo, well printed and strongly bound, ros. $6 \mathrm{~d}$. net.

The object of this "Veterinary Manual" aims at supplying the intelligent horse owner with a thoroughly reliable book upon the general management of the horse in health, and its treatment when suffering from accident or labouring under disease.

Every care possible has been taken to make the work "practical" in its teaching, with an avoidance of technical terms without sacrificing facts of importance.

"The teaching of this book is up-to-date in its character, and it will certainly prove a boon to the farmer or owner when he happens to reside far from veterinary advice, and may require to act in an emergency."-Gilasgow Herald.

\section{The Groom's Guide;}

\section{His Duties and How to Perform Them.}

\section{By FRANK T. BARTON, M.R.C.V.S.}

Crown 8vo, Cloth, 2s. net.

Contents.-Foods and Feeding; Watering; Air; Ventilation; Cleaning Stables; Temperature of Stable Bedding; Disinfectants; Cleaning Harness Mountings, Stirrups, Bits, \&c.; Cleaning Rusty Bits; Cleaning Saddles; Cleaning Harness and Preservation of Same; List of Stable Requisites; Lamps and Candles; Measuring for Harness; Washing and Preservation of Carriages ; Treatment of Horses on Board Ship, \&c.

"The information contained in the book could not well be over-rated, and the publication should be in the hands not only of grooms, but all gentlemen who have grooms in their employ.-County Gentleman. 


\section{BOOKS ON HORSES - cont.}

\section{How to choose a Horse; Or, Selection before Purchase.}

By FRANK T. BARTON, M.R.C.V.S.

Crown 8vo, Cloth, 2s. net.

Contents.-Special Parts and their Relationship to Unsoundness; Buying; The Age of the Horse ; Horse Societies ; Points of Typical Breeds and How to Choose; Objectionable Habits, \&c.

"The book is a valuable addition to literature of the kind."-County Gentleman.

\section{The Horse:}

\section{From Birth to Old Age.}

2n $\mathrm{x}$ Exition.

\section{By S. BUCKMAN-LINARD.}

Fully Illustrated.

Crown 8vo, Cloth, 3s. 6d. net.

Contents.-Veterinary Education; The Sense of Smell in the Horse; The Blood that tells; English and Russian Horses; Teeth and Toothache; Lockjaw; Americans and their Horses; Breeds of Horses in the Old World; Horses: their final uses, \&c., \&c.

“. . . . But Mrs. Linard is undoubtedly an ardent lover of horses, and her book has pleasant pages and much out-of-the way information."-Glasgow Herald.

\section{War Horses:}

\section{Past, Present, and Future;}

OR, LIFE AMONG THE REMOUNTS IN SOUTH AFRICA.

\section{By Sydney Galvayne, Hon. Lieut. Remount Corps.}

Author of "The Horse," "Horse Dentition," Points of the Horse," \&c.

Cloth, 2s. 6d.

Mr. Galvayne was for two and a half years with the Remounts in South Africa.

“Mr. Galvayne's book should be read by everyone."--Sporting Times. Times.

"A plain and detailed record of experiences and much plain spoken criticism."- 


\section{MISCELLANEOUS BOOKS.}

\section{Lightning Tours;}

Flights by Day and Night by Boat and Rail, each mostly within 24 hours.

BY

Percy Fitzgerald, M.A., F.S.A. Author of "The Recreations of a Literary Man," \&c.

\section{Cloth, 2/6}

\section{Age and Old Age.}

A Handbook on Health and Disease.

BY

\section{David Walsh, M.D.}

Author of "The Röntgen Rays in Medical Work,"

"Diseases of the Hair," etc.

\section{Cloth, 2/6}

"Practical as well as interesting."-Aberdeen Free Press.

Henry Warren's New Book on the Methods of Banking.

\section{A Bee among the Bankers;}

or, How to increase your Deposit Rate and reduce your Bankers' Charges.

$\mathrm{BY}$

\section{Henry Warren.}

Author of "How to deal with your Bankers," \&c.

\section{Cloth, $3 / 6$}

"Should prove profitable reading to persons who have money to invest." - Scotsman. 


\title{
MISCELLANEOUS BOOKS \\ (continued.)
}

\section{Lord Curzon in India,}

\section{I898-I903.}

$\mathrm{BY}$

\section{Caldwell Lipsett.}

Author of "Where the Atlantic meets the Sea," \&c.

With Portraits and Illustrations.

\section{Cloth, 2/6}

"Mr. Lipsett has contrived to pack a great deal of information into a very few pages." -Daily Chronicle.

\section{Sharpshooting for}

\section{Sport and War.}

BY

\author{
W. W. Greener.
}

Author of "The Gun and its Development."

\section{Sewed, 1/-; Cloth, 1/6 net.}

\section{Second Edition. Completing 20th Thousand.}

200 pp. Ioo Illustrations.

"In so far as the art of shooting with the rifle can be taught by words, Mr. Greener has essayed to make all who read his treatise proficient sharpshooters, and his remarks, both on sporting and military weapons, are eminently practical."-The Field. 


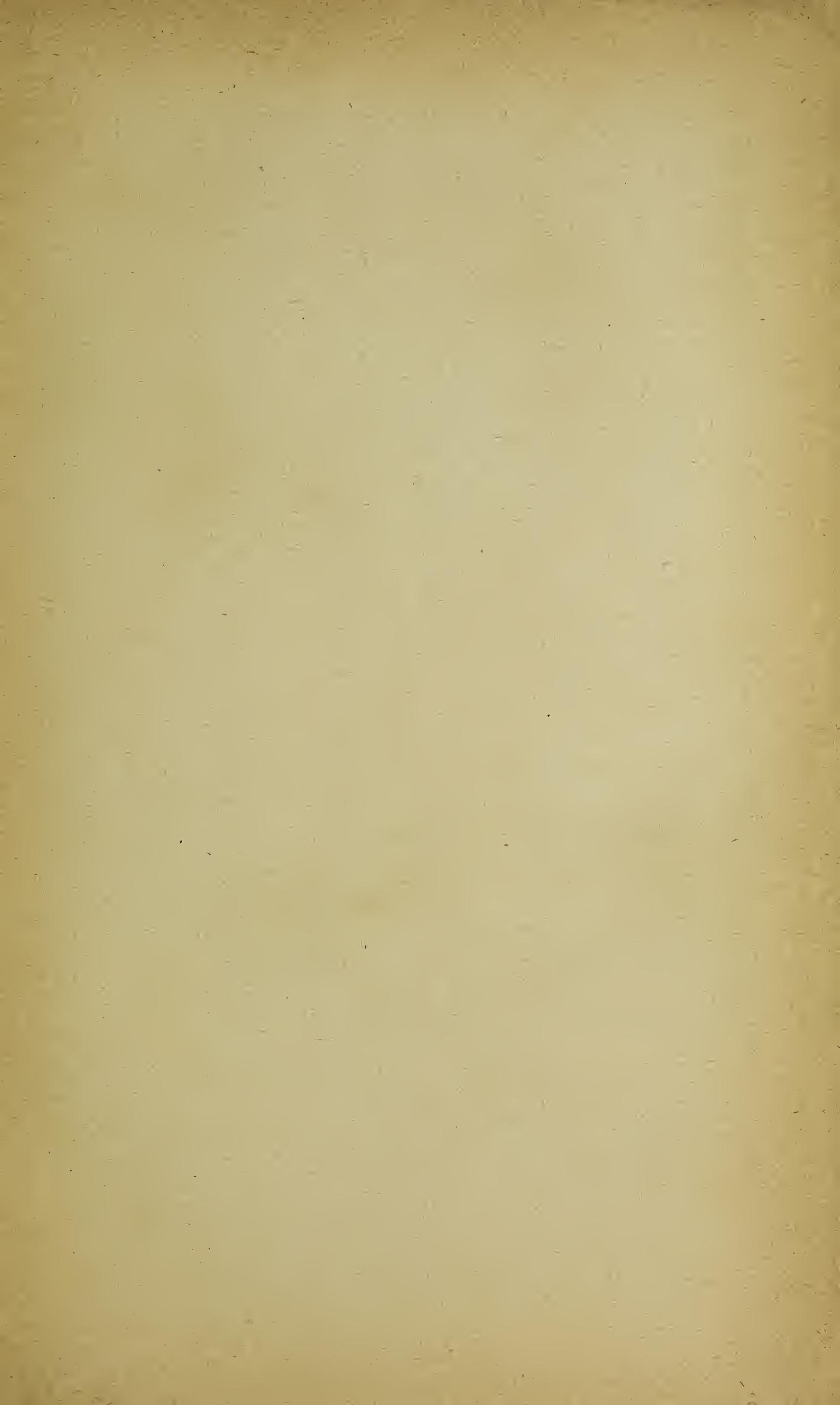



-

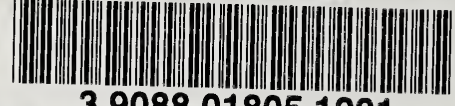

39088018051201

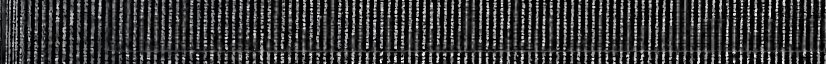
H.W.W.

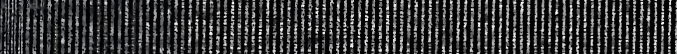

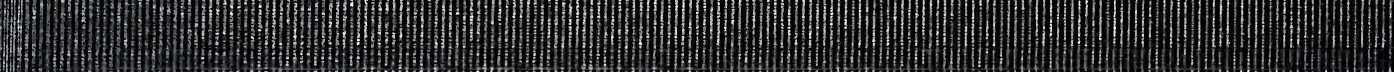

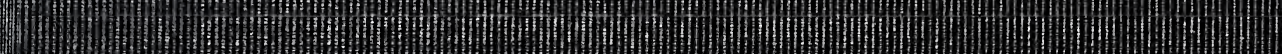
WW

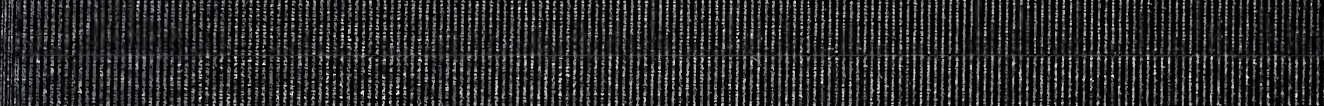

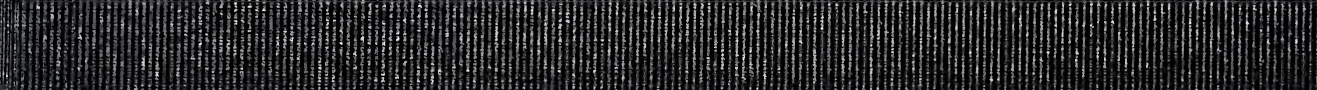

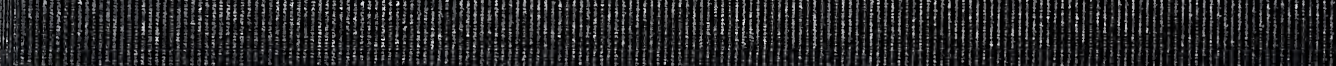

